\title{
A taxonomic revision of Acanthaceae tribe Barlerieae in Angola and Namibia. Part 1
}

\author{
lain Darbyshire ${ }^{1}$ D, Erin A. Tripp ${ }^{2}$ \& Frances M. Chase ${ }^{3}$
}

Summary. In the first part of a taxonomic revision of the tribe Barlerieae (Acanthaceae) in Angola and Namibia, two of the four major clades of the genus Barleria L. are studied in detail, namely subg. Barleria and subg. Prionitis sect. Prionitis. Using standard morphology-based taxonomic methods, a total of 32 species and 39 taxa are delimited, of which 12 are endemic to Namibia, nine are endemic to Angola, a further four are restricted to the two countries combined and four are largely confined to the region. Hence, nearly $70 \%$ of the taxa are endemic or near-endemic to Angola and Namibia. Full descriptions, citations of types and representative specimens, and notes on their habitat(s), ecology and biogeography are provided for each taxon. Seven new species (Barleria calole, B. crabbeoides, B. craveniae, B. deserticola, B. fernandae, B. namba and B. rupicola), two new subspecies (B. lanceolata subsp. tristis and $B$. prionitoides subsp. strigulosa) and one new variety (B. rigida var. spinissima) are described. In addition, Barleria namutonensis Oberm. is treated as a subspecies of B. prionitoides, and $B$. dinteri Oberm. is treated as a subspecies of $B$. coriacea Oberm. and the necessary new combinations are made, whilst B. schenckii Schinz is resurrected as a good species. Eleven names in Barleria are lectotypified. A preliminary assessment of the conservation status and extinction risk is provided for each taxon. Of the 39 taxa enumerated, the majority are assessed to be of Least Concern, but one is assessed as Endangered, four as Vulnerable, one as Near Threatened and six are currently considered to be Data Deficient.

Key Words. IUCN red list assessment, Kaokoveld, lectotype, new species, taxonomy.

\section{Introduction}

The tribe Barlerieae of Acanthaceae subfamily Acanthoideae (McDade et al. 2008) comprises approximately 13 genera and is recognised by plants that have the combination of retinaculate fruits, cystoliths present in the epidermis of the vegetative organs and corollas with quincuncial aestivation. The lattermost character describes corollas where the lateral two petals are positioned outermost in the bud and is synapomorphic for the tribe (Scotland \& Vollesen 2000; McDade et al. 2008). It is readily observed on genera with large, showy corollas such as Barleria L. In continental Africa, the tribe is represented by only four genera: Barleria, Crabbea Harv., Lepidagathis Willd. and Schaueriopsis Champl. \& I. Darbysh. (Champluvier \& Darbyshire 2012).

Barleria is by far the most species-rich genus in the Barlerieae, comprising c. 285 currently accepted species with a further $40-50$ species currently awaiting description (I. Darbyshire, unpubl. data). With the exception of a single amphi-Atlantic species (B. oenontheroides Dum. Cours.), it is a palaeotropical genus that is most diverse in tropical and southern Africa, where several centres of endemism have been identified by Balkwill \& Balkwill (1998). Elsewhere, other important centres of endemism are noted in Madagascar and India (Balkwill \& Balkwill 1998). The genus displays unusually high rates of local endemism in most parts of its range and so is of potentially high conservation interest (Darbyshire \& Luke 2016).

Until recently, the taxonomy of Barleria has been largely neglected in continental Africa since the continent-wide treatment for the Flora of Tropical Africa and Flora Capensis (Clarke 1899, 1901). The only major exception was the excellent treatment of the southern African species by Obermeyer (1933). As a result, the taxonomy of Barleria was in a chaotic state, with large volumes of unidentified specimens and putative undescribed species accumulating in herbaria. Over the last two and a half decades, however, considerable advances have been made in the taxonomy of this genus. The infrageneric classification has been thoroughly revised based on detailed study of morphological characters (Balkwill 1993; Balkwill \& Balkwill

Accepted for publication 10 December 2018. Published online 15 March 2019

1 Herbarium, Royal Botanic Gardens, Kew, Richmond, Surrey, TW9 3AB, UK. e-mail: i.darbyshire@kew.org

2 Museum of Natural History (COLO Herbarium), University of Colorado, Boulder, C105 Ramaley Hall, Campus Box 334, Boulder, CO, 80309-0350, USA.

3 National Herbarium of Namibia, Ministry of Agriculture, Water and Forestry, National Botanical Research Institute, Private Bag 13184, Windhoek, Namibia. 
1997) and is in the process of being further refined through molecular analyses (Darbyshire et al. in press). In Africa, the alpha taxonomy of Barleria has been widely revised through a series of regional and national florisitic treatments and new species accounts including in Northeast Africa (Ensermu 2006; Hedrén 2006a, 2006b; Malombe \& Darbyshire 2010; Ensermu \& Darbyshire 2017), East Africa and the Flora Zambesiaca region (Darbyshire 2008, 2009, 2010a, 2010b, 2015; Darbyshire \& Ndangalasi 2009; Darbyshire \& Luke 2016), Central Africa (Champluvier 2011; Darbyshire 2011) and, to some extent in southern Africa (Balkwill et al. 1990, 1992; Nyirenda 2012; Nyirenda \& Balkwill 2018; Darbyshire et al. 2017). Outside of Africa, the genus has also been revised recently in India (Shendage \& Yadav 2010) and some additional species have been described from Oman (Knees et al. 2007; Mosti et al. 2011) and Madagascar (Darbyshire et al. 2014), the lattermost building on the treatment by Benoist (1967) for the Flore du Madagascar et des Mascarenes.

Our understanding of species diversity and distribution in Barleria is therefore greatly improved over much of its range. However, southwest tropical and subtropical Africa - one of the most important centres of endemism for Barleria - remains largely neglected. This current work aims to close this knowledge gap. Whilst the floras of Angola and Namibia have not traditionally been treated together, it makes sense to do so for Barleria and, indeed, for the wider Acanthaceae in view of the overlap in species diversity and affinities between the two countries, most notably in the cross-border Kaokoveld Centre of floristic endemism (sensu van Wyk \& Smith 2001) which is of considerable importance for Acanthaceae. Below, we review the history of taxonomic studies on Barleria in these two countries and give an overview of the ecological importance of the Acanthaceae in this region of Africa, to provide the context for a regional revision of Barleria.

\section{The history of taxonomic studies on Barleria in Angola and Namibia}

\section{Angola}

Much of our knowledge of Angolan members of Barleria stems from the work of Spencer Moore at the Natural History Museum, London (BM) in the late $19^{\text {th }}$ and early $20^{\text {th }}$ centuries, based principally on the important collections of Friedrich Welwitsch, John Gossweiler \& Hugo Baum (Moore 1880, 1902a, 1911, 1930). The last complete account of the genus in Angola was for the Flora of Tropical Africa (Clarke 1899). Apart from Moore's later studies, the only subsequent work of note was that of Benoist (1950), who based his studies primarily on material collected during the 1937 expedition to Angola by Arthur Wallis Exell and Francisco Mendonça, but also studied other Angolan collections held at the Coimbra (COI) herbarium in Portugal including later Gossweiler collections.

The Conspectus Flora Angolensis (CFA) was launched in 1937, with the aim to document in detail the vascular plant diversity in Angola, using the extensive collections accumulated in both Portuguese and Angolan herbaria during the colonial period. To date, this flora is estimated to be less than a third complete (Beentje 2016). In the early to mid 1970s before Angolan independence from Portugal, the large majority of Angolan collections of Acanthaceae from the main colonial Portuguese herbaria in Lisbon (LISC, LISU) and Coimbra (COI) were loaned to the Luanda (LUAI) herbarium in preparation for a full treatment of the family in CFA. Tragically, the Angolan civil war (1975 - 2002) broke out shortly after independence from Portugal and, not only did progress on CFA all but halt indefinitely (only four small parts have appeared since 1977), but the Acanthaceae material from the Portuguese herbaria was lost and feared to have been destroyed. This supposition remains the case today, as very little material of Acanthaceae once deposited within Portugual has since been recovered (K. Vollesen \& C. Duarte, pers. comm.). Based on the very limited current holdings of Acanthaceae at LUAI, it appears that much of the material from the Angolan herbaria except for that at Lubango (LUBA) suffered the same fate. The most recent report of these missing specimens being extant was from Dr Mariette Manktelow during her Ph.D. studies on systematics of the genus Phaulopsis Willd. In the 1990s, Dr Manktelow used diplomatic means to retrieve material of that genus loaned from Portugual to LUAI in the midst of the civil war. This material was rather badly insect damaged but nonetheless extant (M. Manktelow, pers. comm.). It remains to be seen whether any more of these missing Acanthaceae specimens can be recovered in the future.

Post civil war, there has been very limited botanical exploration in Angola with the exception of the last few years, where several institutions have again begun to explore Angola's rich flora (see Figueiredo \& Smith 2008). However, Angola remains a logistically difficult and expensive country in which to conduct fieldwork, and opportunities for country-wide botanical exploration are limited. In view of the loss of the Portuguese herbarium material, collections of Angolan Acanthaceae available for study are rather limited. Fortunately, collections at BM and Royal Botanic Gardens, Kew (K) were not requested on loan and so remain intact, including the large majority of Angolan type material, as does the Welwitsch Acanthaceae 
collection at LISU, which was not loaned out. A sizable collection is also held at LUBA and some limited material remains extant at LISC, LUAI and the Pretoria Herbarium (PRE). These collections, together with specimens made during recent botanical surveys, form the basis of the account of Barleria in Angola presented here.

In the landmark checklist of the vascular plants of Angola (Figueiredo \& Smith 2008), 32 species of Barleria were listed, with four recorded as endemic to Angola (Makholela 2008). However, a review by the first author of extant Angolan material of Barleria indicated that there are a number of undescribed species as well as a number of taxonomic issues to resolve, and that the endemism rate is considerably higher than that noted in the checklist. As such, an updated treatment of Angolan Barleria is sorely needed.

\section{Namibia}

The Acanthaceae of Namibia were last treated for the Prodromus einer Flora von Südwestafrika by Meyer (1968), who listed 22 species of Barleria. This work built on the regional treatments of Barleria in southern Africa by Clarke (1901) and Obermeyer (1933). Whilst Meyer's account is thorough and largely accurate, four factors render a modern revised treatment both necessary and timely: (1) Meyer's (1968) account lacks detailed species descriptions and, whilst his earlier preparatory work on Barleria (Meyer 1957) includes descriptions for some species, the majority remain without; (2) there have been a number of taxonomic and nomenclatural changes since Meyer's studies; (3) there has been a wealth of botanical exploration in Namibia since the $1960 \mathrm{~s}$, with resultant collections housed primarily at the herbarium of the National Botanical Research Institute (NBRI) in Windhoek (WIND herbarium), and these more modern collections have greatly increased our understanding of the distribution patterns of and variation within the Namibian species; and (4) there exist both new species and new subspecies from Namibia in need of formal naming. In a reconnaissance checklist in preparation for the current study, Darbyshire et al. (2012) recorded 26 species of Barleria, nine of which were considered endemic and two as near-endemic.

NBRI has recently launched a new Flora of Namibia programme (see www.nbri.org.na/projects/the-floraof-namibia; Bruyns 2015; Struwig et al. 2015) aimed at documenting in detail plant diversity and distributions within this botanically fascinating country. This work is supported by the Southern African Science Service Centre for Climate Change and Adaptive Land Management (SASSCAL) project Task 060, to "Establish and Improve baseline inventories for spatial data and biodiversity - Flora of Namibia Project". Acanthaceae was chosen as one of a number of top priority groups for study for the new Flora, given its exceptional ecological importance and high levels of endemism within the country (Craven 2009; and see below). An account of Barleria in Namibia will be extracted from the current work in due course as a contribution to this Flora series.

\section{The ecological importance of Acanthaceae in Angola and Namibia}

There are few other places across Earth where one can witness the ecological abundance and landscape dominance achieved by species of Acanthaceae as in Namibia and southern portions of Angola. In Namibia alone, Acanthaceae is the sixth most diverse family of flowering plants (c. 160 species, 23 genera) but ranks third in total number of endemic species (c. 45 species), just after Mesembryanthemaceae (Aizoaceae) and Asteraceae (Craven 2009; Darbyshire et al. 2012; Tripp \& Dexter 2012). In the Kaokoveld Centre of Endemism of northwestern Namibia and southwestern Angola, Acanthaceae ranks fourth among all families of flowering plants in total numbers of species (following Poaceae, Fabaceae and Asteraceae), but first in total number of endemic species (Craven 2009; Tripp et al. 2017).

Huge portions of the landscape in Namibia and southern Angola are covered by Acanthaceae, where species serve as a major source of fodder for the herbivorous megafauna (Tripp et al. 2013; Craven 2014, unpublished report; E. Tripp, pers. obs.). This dominance across the landscape seems driven in large part by parallel evolutionary adaptations to the arid or ultra-arid Namib desert and flanking woodlands in four major, distantly related lineages in the family: Barleria (Barlerieae), Blepharis Juss. (Acantheae), Justicia L. sensu lato (including Monechma Hochst.; Justicieae), and Petalidium (Ruellieae; Tripp et al. 2017). These genera have slightly different affinities for a preciptation gradient that transitions from exceptionally dry $(<100 \mathrm{~mm} / \mathrm{yr})$ to semi-dry $(>100-$ $250 \mathrm{~mm} / \mathrm{yr}$ ) along a west-to-east trajectory, with Blepharis and Petalidium occupying generally drier, western portions of this gradient and Barleria and Justicia occupying slightly less dry, more inland habitats. The parallel diversification of species in these four genera (each with >25 spp.; Klaassen \& Kwembeya 2013) is even more noteworthy given the extreme climatic regime in most of Namibia and southern Angola, which experiences precipitation only in hot, summertime months when evapotranspiration is exceptionally high. This is in striking contrast to nearby Mediterranean precipitation regimes that characterise large portions of South Africa, including the hyperdiverse Cape Floristic Province and succulent Karoo, which receive precipitation during cool, 
wintertime months (Tripp et al. 2017). That major portions of these two countries host some of the highest concentrations of total numbers, total endemics, and ecologically dominant species of Acanthaceae makes this area of even greater interest because Acanthaceae has been the subject of taxonomic revision in much of sub-Saharan African (e.g. Hedrén \& Thulin 2006; Ensermu 2006; Vollesen 2008, 2013; Darbyshire et al. 2010, 2015b) but not in Namibia or Angola, where they are in need of extensive taxonomic revision. Revising Barleria will contribute significantly towards the broader objective of a complete treatment of Acanthaceae in Namibia and southern Angola, in combination with ongoing work on other important genera of Acanthaceae, including Petalidium (Tripp et al. 2017), Ruellia L. and the segregate genus Dinteracanthus Schinz which is endemic to this region (Tripp \& Dexter 2012; Tripp \& Darbyshire 2017).
We present here the first part of a full revision of the genus Barleria in Angola and Namibia. This part covers subg. Barleria (sensu Darbyshire et al. in press) and subg. Prionitis (Nees) C. B. Clarke sect. Prionitis Nees, with 32 species treated in total, as summarised in Table 1. This is just over half of the total number of Barleria species in Angola and Namibia. The second part, comprising a further c. 29 species within subg. Prionitis sections Somalia (Oliv.) Lindau and Stellatohirta M. Balkwill, will be published in the near future. A third paper (Darbyshire, in prep.) is intended to focus on the two other genera of tribe Barlerieae that occur in Angola and Namibia: Crabbea and Lepidagathis. In light of the few collections available for many of the Angolan species, this account must be treated as a first modern iteration and it is likely that there will be further new species discovered and potentially further taxonomic changes as more material becomes available and as further field studies supplement our

Table 1. Species treated in the present study, section/subgenus to which each belongs, geographical range and conservation assessments assigned herein. Under range, "Endemic" status noted for plants endemic to either Angola, Namibia, or both.

\begin{tabular}{|c|c|c|c|}
\hline Species & Section/Subgenus & Range & Conservation Assessment \\
\hline B. ameliae & Prionitis & Namibia, Widespread & Least Concern \\
\hline B. brownii & Barleria & Angola, Widespread & Least Concern \\
\hline B. calole & Prionitis & Angola (Endemic) & Data Deficient \\
\hline B. capitata & Barleria & Namibia, Widespread & Least Concern \\
\hline B. carruthersiana & Barleria & Angola (Endemic) & Data Deficient \\
\hline B. coriacea subsp. dinteri & Prionitis & Namibia (Endemic) & Least Concern \\
\hline B. crabbeoides & Barleria & Angola (Endemic) & Data Deficient \\
\hline B. crassa subsp. crassa & Barleria & Angola, Widespread & Least Concern \\
\hline B. craveniae & Barleria & Namibia (Endemic) & Least Concern - "Rare" \\
\hline B. cyanea & Barleria & Angola, Namibia (Endemic) & Near Threatened \\
\hline B. damarensis & Barleria & Namibia (Endemic) & Least Concern \\
\hline B. deserticola & Barleria & Angola (Endemic) & Least Concern - "Rare" \\
\hline B. elegans subsp. elegans & Barleria & Angola, Namibia (Endemic) & Least Concern \\
\hline B. fernandae & Prionitis & Angola (Endemic) & Data Deficient \\
\hline B. jubata & Barleria & Namibia (Endemic) & Vulnerable \\
\hline B. kaloxytona & Prionitis & Namibia (Endemic) & Least Concern \\
\hline B. lanceolata subsp. A & Barleria & Namibia (Endemic) & Least Concern \\
\hline B. lanceolata subsp. lanceolata & Barleria & Namibia, Botswana & Least Concern \\
\hline B. lanceolata subsp. tristis & Barleria & Namibia (Endemic) & Least Concern \\
\hline B. lichtensteiniana & Barleria & Namibia, South Africa & Least Concern \\
\hline B. macrostegia & Barleria & Namibia, Widespread & Least Concern \\
\hline B. meeuseana & Barleria & Angola, Namibia (Endemic) & Least Concern \\
\hline B. merxmuelleri & Barleria & Namibia (Endemic) & Least Concern \\
\hline B. namba & Barleria & Angola (Endemic) & Vulnerable \\
\hline B. obtusisepala & Prionitis & Angola (Endemic) & Data Deficient \\
\hline B. papillosa & Barleria & Namibia, South Africa & Vulnerable \\
\hline B. prionitoides subsp. namutonensis & Prionitis & Angola, Namibia (Endemic) & Least Concern \\
\hline B. prionitoides subsp. prionitoides & Prionitis & Namibia (Endemic) & Vulnerable \\
\hline B. prionitoides subsp. strigulosa & Prionitis & Angola (Endemic) & Least Concern \\
\hline B. pseudosomalia & Prionitis & Namibia, Tanzania & Endangered \\
\hline B. rigida var. ilicina & Barleria & Namibia, South Africa & Least Concern \\
\hline B. rigida var. latibracteata & Barleria & Namibia, Botswana & Least Concern \\
\hline B. rigida var. rigida & Barleria & Namibia, South Africa & Least Concern \\
\hline B. rigida var. spinissima & Barleria & Namibia (Endemic) & Least Concern - "Rare" \\
\hline B. rupicola & Barleria & Angola (Endemic) & Least Concern \\
\hline B. schenckii & Barleria & Namibia (Endemic) & Data Deficient \\
\hline B. senensis & Prionitis & Angola, Namibia, Widespread & Least Concern \\
\hline B. solitaria & Barleria & Namibia (Endemic) & Least Concern - ?"Rare" \\
\hline B. villosa & Barleria & Angola, Widespread & Least Concern \\
\hline
\end{tabular}


collections-based knowledge. It is hoped that this work will stimulate future research into this fascinating genus in southwestern Africa.

\section{Materials \& Methods}

Herbarium collections of Barleria from Angola, Namibia and, where applicable, neighbouring countries were studied at or on loan from a range of herbaria with relevant holdings, most notably BM, K, LUAI, LUBA, LISC, LISU, M, PRE and WIND, with additional material from B, BR, DR and SRGH (abbreviations follow the standard form listed on Index Herbariorum: sweetgum.nybg.org/science/ih/). The holdings of the genus at the following herbaria were studied via their respective online catalogues: L and WAG (http:// bioportal.naturalis.nl/), P (https://science.mnhn.fr/ all/search) and Z (www.herbarien.uzh.ch/en/ Datenbanken.html). Additional type specimens were observed online in JSTOR Global Plants (https:// plants.jstor.org/). As there is only limited material available for study from Angola (see Introduction), all Angolan specimens seen are cited. For Namibia, where there is much more material available for most species, a representative selection of specimens is cited, except for scarce species for which all material seen is listed. Where only selected material is cited, the total number of specimens seen from the two countries is also listed to give an indication of the abundance of the species in the region. Non-type material from outside Angola and Namibia is only cited where there has been past taxonomic or nomenclatural confusion or where a species' range beyond these two countries is highly restricted (i.e. the species is near-endemic to the region). All duplicates seen by at least one of the authors are marked with an "!"; specimens or duplicates seen only in the form of digital images are marked with an "*". Barcodes are included for all type specimens where available.

Herbarium specimens were analysed using standard herbarium practices. Prior to dissection, flowers were soaked in Aerosol OT 5\% solution; measurements of vegetative organs were made on dry material.

All specimens seen from Angola and Namibia have been georeferenced wherever possible, primarily using online and published gazetteers (notably GeoNames: www.geonames.org/; Fuzzy Gazetteer: http://dma.jrc.it/services/gazetteer/) and Google Earth $^{\mathrm{TM}}$. For Namibia, an extract of the WIND specimen database, which also lists Namibian specimens held at PRE, was kindly provided by Esmerialda Strauss at NBRI. This database includes georeferenced locality data, the majority following the "quarter degree square" (QDS) method employed in southern Africa (see Leistner \& Morris 1976). These averaged QDS co-ordinates have been maintained in the mapping of widespread species. However, for those species with a restricted range, more detailed georeferencing was carried out to provide a more accurate measure of the species' distribution. The precise localities of some of the early collections from both countries proved difficult to pinpoint with accuracy; this included many of the localities from Welwitsch's three Angolan expeditions (see Albuquerque \& Correia 2009). Some itineraries of early expeditions proved to be useful in pinpointing localities, particularly for the expeditions of Mary Pocock (Balarin et al. 1999) and Hugo Baum (Figueiredo et al. 2009). The distribution maps were produced using QGIS version 2.14.4 (available online at https://www.qgis.org/en/site/forusers / download.html).

The habitat descriptions for each species are accompanied, where possible, with brief notes on phytogeography. In particular, we note where a species' range coincides with one of White's (1983) phytochoria of Africa, Linder's (2001) proposed centres of endemism, van Wyk \& Smith's (2001) regions and centres of floristic endemism in southern Africa and/or Craven's (2009) floristic groups of Namibia. For those species occurring in Namibia, we also note the vegetation type(s) in which they occur, following the classification used in Mendelsohn et al.'s (2002) Atlas of Namibia, which builds on the preliminary vegetation map of Namibia of Giess (1971). The phytogeography of Angola requires further study and so the notes for the Angolan species are provisional.

Wherever required and possible, accepted names and synonyms are lectotypified from amongst the original material or neotypified in the absence of extant original material. With regard to the Welwitsch collections studied by Spencer Moore, he annotated both the BM sheets (where he was based) and also the $\mathrm{K}$ duplicates which were perhaps only distributed following his taxonomic research, and so lectotypifications are required for Moore's names based on Welwitsch types. Neotypifications are primarily required for Namibian species that were described by German botanists from material housed at the Berlin herbarium (B) during the German colonial period of German South-West Africa, 1884 - 1915. Most of the material of Acanthaceae housed at B was destroyed during the bombing campaign of the allied forces on Berlin in World War II which resulted in the partial destruction of the Berlin Natural History Museum, although some specimens of Barleria did survive.

The species conservation (extinction risk) assessments follow the Categories and Criteria of IUCN (2012), but with the additional use of the "Rare" and "Critically Rare" categories used in the Red List of South African Plants (Raimondo et al. 2009), which are applied to naturally rare and/or highly range restricted species that are not threatened and so fall under 
the Least Concern category of IUCN (2012). Extent of Occurrence (EOO) was calculated using the Geocat tool (www.geocat.kew.org; Bachman et al. 2011). Area of Occupancy (AOO) is not used except in specific circumstances where we are confident that we have a good understanding of the number and distribution of localities for a species. For those species occurring predominantly or wholly in Angola, the paucity of material available renders AOO an inaccurate measurement of range. In some cases where species are recorded from outside of Angola and Namibia, data were imported into Geocat from GBIF (https://www.gbif.org) to allow a calculation of global EOO. The few collections and paucity of ecological information on the Angolan species and their habitats makes full assessments for some of the endemic species impossible and so an assessment of Data Deficient (DD) has to be applied in these cases, but this category is avoided wherever possible.

\section{Taxonomic Account}

Barleria L. (Linnaeus 1753: 636); Nees (1847: 223); Clarke (1899: 140; 1901: 44); Obermeyer (1933: 127); Heine (1963: 419; 1966: 161); Benoist (1967: 136); Meyer (1968: 8); Balkwill \& Balkwill (1997: 551); Ensermu (2006: 401); Hedrén (2006b: 427); Darbyshire (2009: 601 - 611; 2010b: 325; 2015: 37); Shendage \& Yadav (2010: 82). Type species: Barleria cristata L. Wahabia Fenzl (1844: 312), nom. nud.

Barleriacanthus Oerst. (Oersted 1854: 136).

Barlerianthus Oerst. (Oersted 1854: 136).

Barleriosiphon Oerst. (Oersted 1854: 136).

Barlerites Oerst. (Oersted 1854: 137).

Dicranacanthus Oerst. (Oersted 1854: 136).

Pseudobarleria Oerst. (Oersted 1854: 135).

Parabarleria Baill. (Baillon 1890: 837).

Prionitis (Nees) Oerst. (Oersted 1854: 137).

Isaloa Humbert (1937: 316).

Perennial herbs, suffrutices, shrubs or climbers, sometimes spiny; stems angular or subterete; cystoliths present, numerous, often occuring in adjacent cells and sometimes appearing to cross, \pm conspicuous. Leaves evergreen or deciduous, opposite-decussate, petiolate or sessile, pairs equal or somewhat anisophyllous, margin (sub) entire or more rarely toothed or spinose. Inflorescences simple and axillary or compounded into a terminal synflorescence; cymose with monochasial and/or dichasial branching or cymes reduced to a single flower; bract pairs (sub-)equal, foliaceous or reduced and/or highly modified; bracteole pairs equal or dimorphic, often highly modified from the bracts. Calyx divided almost to the base, 4-lobed, anterior and posterior (outer) lobes usually considerably larger and proportionally broader than the lateral (inner) lobes, anterior lobe often emarginate or bifid. Corolla usually showy; tube cylindrical throughout or campanulate to funnelshaped above insertion point of stamens; limb 5-lobed or rarely the adaxial pair fully fused or absent, subregular to zygomorphic (see note). Perfected stamens 2 or rarely 4; filaments inserted at various levels within the corolla tube, anterior pair of stamens with filaments twisted through $180^{\circ}$ and crossing near the base; anthers bithecous, thecae parallel, muticous, exserted or rarely included within the corolla tube; staminodes (or imperfect stamens - see note) 2 or 3 , adaxial staminode often less well developed than the lateral pair or absent, with or without antherodes, these often producing a few pollen grains. Disk cupular. Ovary 2-locular, 2 ovules per locule or one aborting very early; style filiform; stigma subcapitate to linear, either with 2 subconfluent lobes, or with 1 lobe much-reduced or absent. Capsule \pm compressed laterally, fertile portion rounded to fusiform, with or without a prominent sterile apical beak, placental base inelastic but lateral walls sometimes thin and tearing from the thickened flanks at dehiscence; seeds 2 or 4 per capsule, held on retinacula, usually (ovate- or triangular-) discoid and with surfaces covered in long hygroscopic hairs, rarely only subflattened and with unevenly distributed minute hairs.

The species descriptions largely follow the terminology of Balkwill \& Balkwill (1997). An explanation of some of the terminology is, however, required for some characters; this is adapted from Darbyshire (2015):

\section{Calyces}

Although comprising a single whorl, the anterior and posterior lobes are typically larger than the two lateral lobes and often enclose them. The anterior and posterior lobes are therefore referred to collectively as the "outer lobes". The colour, shape and indumentum of the posterior lobe is only described if differing from that of the anterior lobe.

\section{Corollas}

Corolla morphology is rather variable in Barleria and the arrangement of the lobes can be divided into several configurations in our region:

Subregular: in which the lobes of the corolla are divided from the tube at \pm the same point and are subequal in size, although the adaxial pair are often slightly narrower and the abaxial lobe is often slightly broader than the lateral pair (e.g. Figs 4 and 8C-D).

" $2+3$ " configuration: in which the adaxial pair of lobes form a 2-lobed upper lip and the abaxial and lateral lobes form a 3-lobed lower lip. In some cases, such as in Barleria solitaria P. G. Mey. and some species in sect. Somalia, the adaxial pair of lobes are partially fused, so that the two lips are quite pronounced. In some species of subg. Barleria the adaxial pair of lobes 
are not partially fused but differ sufficiently from the lateral and abaxial lobes to form a 2-lobed upper lip (e.g. Fig. 6G).

" $1+3$ " configuration: an extreme form of the " $2+3$ " configuration in sect. Somalia in which the adaxial pair of lobes fully fuse; this is only seen in Barleria lugardii C. B. Clarke in our region.

"4+1" configuration: the abaxial corolla lobe splits away from the tube considerably earlier than the lateral and adaxial lobes, the resultant limb being highly zygomorphic with a 1-lobed lower lip and 4-lobed upper lip (e.g. Fig. 15C, $\mathrm{D}, \mathrm{H})$. This is the most widespread limb configuration in the genus. In some species, the offset of the abaxial lobe is only slight and so the arrangement is intermediate between " $4+1$ " and subregular.

The length of the corolla tube is measured from the base to the point at which the first corolla lobe splits; in species with the " $4+1$ " configuration, the length by which the abaxial lobe is offset from the remaining lobes (this being an "open tube") is also recorded. The length of the corolla is measured from the base of the tube to the apex of the lateral lobes when flattened.

\section{Androecium}

The flowers of most species of Barleria have two perfected abaxial stamens, whilst the two lateral and single adaxial androecial elements are much reduced (or very rarely absent — Balkwill \& Balkwill 1997; Darbyshire et al. 2014). In some cases, these reduced elements lack any vestiges of anthers and so can unambiguously be classed as staminodes - this is the case for all species in sect. Somalia, for example. However, the lateral pair can often bear small or vestigial anthers (in the descriptions referred to as antherodes), which can produce some pollen grains. This has led some authors to treat these as reduced stamens, and this may be technically correct. Singh et al. (2015) studied the flowers of Barleria elegans S. Moore ex C. B. Clarke and found that, at the end of the day of anthesis, the corolla detaches from the calyx and receptacle and slides along the style until the stigma is caught by the reduced stamens and is potentially self-pollinated by the few pollen grains present in the reduced anthers (antherodes). They tested this theory using controlled experiments in which the anthers of the two perfected stamens were removed before anthesis, and they found that the stigma does indeed pick up pollen from the reduced stamens. It is quite common to see Barleria flowers hanging from the trapped style and stigma late in the day, suggesting that this selfing mechanism might be widespread in the genus. However, in some species the presence and development of antherodes on the lateral androecial elements can be variable such that it is inconsistent as to whether they are technically stamens or staminodes. For the sake of consistency, these reduced androecial elements are always referred to as staminodes in the descriptions and keys here, but we note the presence or absence (and size) of antherodes on the lateral pair.

In rare cases, four or even five perfected stamens are present in Barleria species; in our region this only applies to the newly described $B$. deserticola I. Darbysh. $\&$ E. Tripp. In the species descriptions, we have not listed the number of perfected stamens for each species except for $B$. deserticola, as two stamens are perfected for all the other species treated here.

Under the revised infrageneric classification proposed by Darbyshire $e t$ al. (in press), two subgenera are recognised, subg. Barleria and subg. Prionitis, and the latter is divided into three sections, Prionitis, Somalia and Stellatohirta. All four of these taxa are well represented in our region. Sects. Fissimura M. Balkwill and Chrysothrix M. Balkwill are included within subg. Barleria, whilst sect. Cavirostrata M. Balkwill is included within sect. Somalia (Darbyshire et al. in press). A key to the infrageneric taxa is presented below; species are keyed out at the beginning of the account of each section or subgenus, but it is our intention to also provide a key to all species in the second part of this revision.

\section{Key to infrageneric taxa of Barleria in Angola and Namibia}

1. Plants with stellate and/or dendritic hairs present; inflorescences dense spikes or heads; capsule 2-seeded, lacking a prominent beak, septum membranous; corolla tube cylindrical, only slightly widened towards the

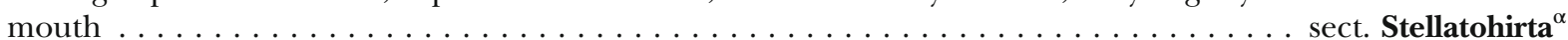
Plants with simple or biramous hairs only, or plants glabrous; inflorescences various; capsule 2- or 4seeded, with or without a prominent beak, if 2-seeded and lacking a prominent beak then corolla tube

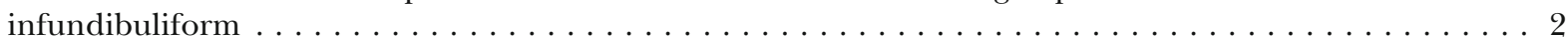

2. Corolla usually yellow, orange or apricot, rarely white or violet-tinged; plants often armed with rayed axillary spines clearly differentiated from the bracteoles (Fig. 14C); capsule 2-seeded, prominently beaked, septum woody throughout, seeds with straight silky hygroscopic hairs . . . . . . . . . . . . sect. Prionitis (p. 62) Corolla white, pink, blue, purple or red, rarely pale yellow; plants spiny or not, if axillary spines present then these paired, being the persistent bracteoles of an old or aborted inflorescence; if capsule 2-seeded and prominently beaked, then septum with a shallow membranous portion above the retinacula and seeds with 


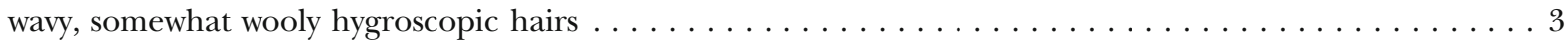

3. Capsule fusiform or elliptic in face view, lacking a prominent beak, usually drying black or brown-black; seeds with \pm straight hygroscopic hairs typically drying brown to purple; plants often spiny; lateral staminodes with or

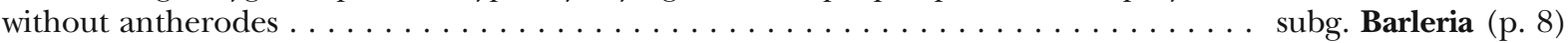
Capsule with a prominent sterile beak above the rounded or fusiform fertile portion, drying pale brown; seeds with wavy, somewhat wooly cream-coloured hygroscopic hairs; plants always lacking spines; staminodes always lacking antherodes . . . . . . . . . . . . . . sect. Somalia $^{\alpha}$

${ }^{\alpha}$ to be treated in Part II of this taxonomic revision.

\section{Barleria subg. Barleria}

Barleria subgen. Acanthoidea sensu Clarke (1899: 141). Barleria subgen. Eu-Barleria 'Villosae' sensu Clarke (1899: 144), pro parte.

Barleria sect. Eubarleria sensu Obermeyer (1933: 133 138), pro parte excl. subsect. Thamnotrichae.

Barleria sect. Chrysothrix M. Balkwill (in Balkwill \& Balkwill 1998: 110) pro maj. parte; Balkwill \& Balkwill (1997: 558) pro maj. parte.

Barleria sect. Fissimura M. Balkwill (in Balkwill \& Balkwill 1998: 110); Balkwill \& Balkwill (1997:

569); Darbyshire (2010b: 355; 2015: 81)..

Axillary spines absent or plants with the spinose bracteoles of aborted or old inflorescences persisting as paired axillary spines. Indumentum simple or stellate. Inflorescences unilateral, dichasial or single-flowered cymes, axillary with bracts foliaceous, or compounded into a terminal open or spiciform thyrse with \pm modified bracts. Calyx often turning scarious with age, outer lobes usually with \pm conspicuous palmatereticulate venation. Corolla white, blue, purple or red, rarely yellow (B. oenotheroides), often drying blue with darker venation or blue-black throughout; limb in " $4+1$ ", " $2+3$ " or subregular configuration. Stamens 2 or 4 perfected; staminodes 1 or 3, lateral pair with antherodes well-developed or absent, adaxial staminode with antherode usually absent. Pistil with stigma linear, clavate or (sub)capitate, apex \pm bilobed. Capsule usually drying black or dark brown, laterally flattened, oblong-fusiform or (obovate-) fusiform, without a prominent beak; lateral walls sometimes tearing from thickened flanks at dehiscence; septum either with a shallow membranous portion above upper retinacula and elsewhere woody, or membranous throughout; seeds 2 or 4, discoid with dense matted hygroscopic hairs, often purplish, brown or bronze in dry state.

Under its expanded circumscription, incorporating sects. Chrysothrix and Fissimura, subg. Barleria comprises c. 150 species, with 24 species in Angola and Namibia. It is most diverse in southern and eastern Africa. Plants of the former sect. Fissimura (2-seeded capsules with wholly membranous septa, plants lacking spines - species 22 - 24 here) tend to be found in more humid climates than those of other members of subg. Barleria (4-seeded capsules with only partially membranous septa, plants often spiny). Molecular evidence (Darbyshire et al. in press) demonstrates that, whilst a monophyletic group, sect. Fissimura evolved from within the former sect. Barleria and so must be included within the latter to avoid paraphyly. Morphological evidence provides some support for this finding, as there are a number of 4-seeded species that are otherwise closely allied to species of sect. Fissimura (e.g. B. gueinzii Sond., $B$. holstii Lindau and $B$. repens Nees). Indeed, Obermeyer (1933) included the southern African species of sect. Fissimura as a subsection ("Dispermae") within her sect. "Eubarleria" which contained the 4seeded members of subg. Barleria.

\section{Key to species of Barleria subg. Barleria in Angola and Namibia}

1. Corolla with adaxial pair of lobes fused for up to half their length, fused portion white with prominent purple speckling; cymes always single-flowered; young stems somewhat succulent, soon becoming woody with white

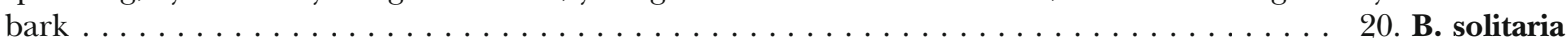
Corolla with adaxial pair of lobes not partially fused or if shortly so at base then lacking purple speckling;

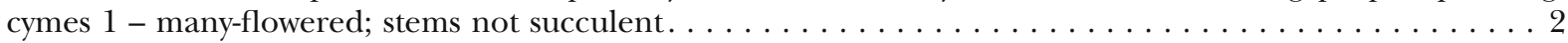

2. Plants spiny or at least mucronate on the bracteoles, leaf tips and/or calyces; capsule 4-seeded; plants never

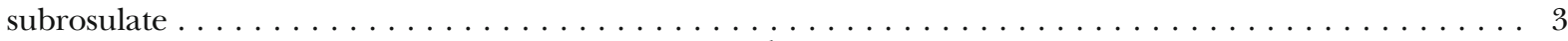
Plants lacking spines; capsule 2 -seeded or if 4 -seeded ${ }^{1}$ then plants subrosulate $\ldots \ldots \ldots$. . . . . . . . 21

\footnotetext{
${ }^{1}$ Capsules not seen in B. crabbeoides but considered likely to be 4-seeded in view of its affinities.
} 
3. Adaxial pair of corolla lobes subulate or narrowly spathulate, up to $3 \mathrm{~mm}$ wide; leaves coriaceous with 1 - 10

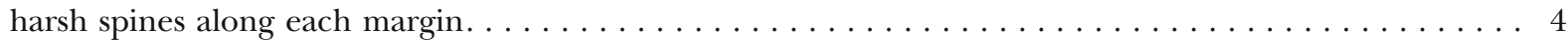
Adaxial pair of corolla lobes elliptic, oblong-elliptic, obovate, ovate or lanceolate, $3-15$ mm wide; leaves

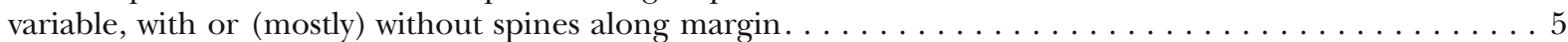

4. Posterior calyx lobe broadly ovate or ovate-elliptic, $(6-) 11$ - $15 \mathrm{~mm}$ wide, base obtuse to shallowly cordate; calyx densely and conspicuously glandular-pubescent; capsule glossy (green-) black, largely enclosed within

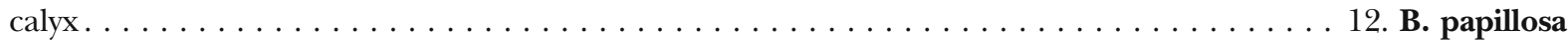
Posterior calyx lobe elliptic or obovate, $4-5.5 \mathrm{~mm}$ wide, base cuneate; calyx with minute and inconspicuous glandular hairs only; distal half of capsule matt-black, exposed beyond calyx . . . . . . . . 13. B. craveniae

5. Leaves with sinuate white-cartilaginous margin, this often toothed or spinose; bracteoles with conspicuously spinose margins, or if subentire then up to $3 \mathrm{~mm}$ wide $\ldots \ldots \ldots \ldots \ldots \ldots$ Leaves with margin entire or with spinulose teeth but not white and sinuate; or if with a narrow white toothed margin (B. macrostegia) then bracteoles with margin entire or at most minutely toothed, $(7-) 10-20 \mathrm{~mm}$ wide7

6. Bracteoles linear-lanceolate to lanceolate, usually less than $5 \mathrm{~mm}$ wide but if wider then base cuneate; posterior calyx lobe without revolute margin; corolla externally usually with mixed glandular and eglandular hairs, rarely (var. spinissima) with eglandular hairs only $\ldots \ldots \ldots \ldots \ldots \ldots \ldots \ldots \ldots \ldots \ldots \ldots \ldots$ rigida Larger of each pair of bracteoles broadly lanceolate, $5-8.5 \mathrm{~mm}$ wide, base rounded, truncate or subcordate; posterior calyx lobe with margin revolute and can partially envelope the anterior lobe; corolla externally with

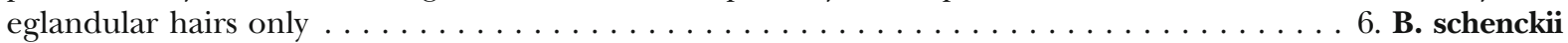

7. Bracteoles narrow: linear, lanceolate, oblanceolate, narrowly elliptic or spinose, $0.5-5 \mathrm{~mm}$ wide excluding (if present) marginal teeth or spines, not imbricate and not partially enclosing the calyces; outer calyx lobes variously shaped, posterior lobe $1.8-16 \mathrm{~mm}$ wide $\ldots \ldots \ldots \ldots \ldots$ Bracteoles broad: ovate or lanceolate, pairs often unequal in size, the larger of each pair $5-20 \mathrm{~mm}$ wide excluding (if present) marginal teeth or spines, imbricate and partially enclosing the calyces, forming a strobilate unilateral cyme, axis often becoming markedly inrolled at fruiting stage; outer calyx lobes large,

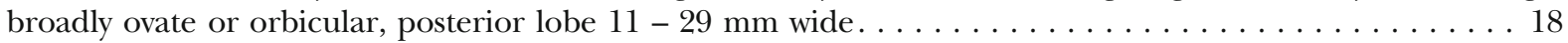

8. Corolla tube cylindrical throughout or at most slightly widened towards the mouth; style base with a dense ring of white crisped hairs; young stems with only sparse strigose hairs, indumentum either sparse or dominated by

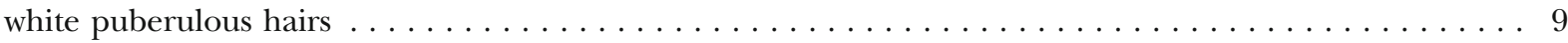
Corolla tube narrowly to broadly funnel-shaped above insertion point of stamens; style base with short straight declinate or erect hairs or largely glabrous; young stems with dense strigose to stiff spreading buff or yellow

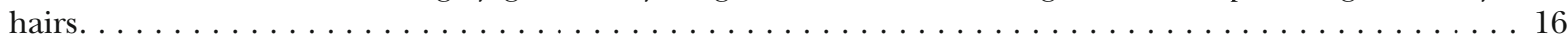

9. Bracteoles reflexed, margins usually toothed; cymes (1 -) 2 - 6-flowered; corolla with dark red to purple-black markings (nectar guides) at the base of the lobes and in the mouth; uppermost stem internodes with sparse to dense short glandular hairs, elsewhere stems densely white-puberulous . . . . . . . . . 11. B. damarensis Bracteoles straight or apex slightly curved, not reflexed or if slightly so (B. cyanea) then margins entire and cymes always single-flowered; corolla with or often without nectar guides; stem indumentum variable but glandular hairs often absent, never densely glandular-hairy $\ldots \ldots \ldots \ldots$

10. Outer calyx lobes broadly ovate, l:w ratio $1-2.3: 1$, margin entire or minutely toothed . . . . . . 8. B. lanceolata Outer calyx lobes variously elliptic, oblong-elliptic, ovate or lanceolate, l:w ratio (excluding, if present, lateral spines or teeth) over 2.3: 1 or if lower then lobes with conspicuous marginal spines . . . . . . . . 11

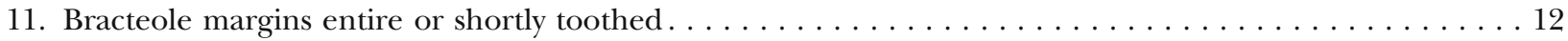

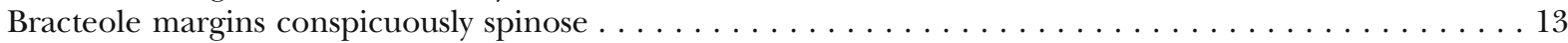

12. Stems with short white antrorse hairs restricted to two opposite lines; leaves pale-strigose only, mainly on margin and veins beneath, not appearing silvery; bracteoles $1.5-4.5 \mathrm{~mm}$ long; margins of outer calyx lobes

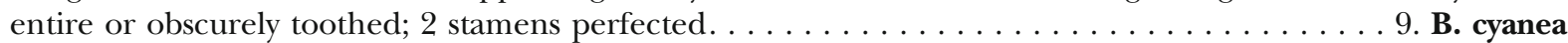
Stems with short white retrorse hairs throughout; leaves white-puberulent in addition to the strigose hairs, giving the leaves a silvery appearance at least when young; bracteoles $3.5-11 \mathrm{~mm}$ long; margins of outer calyx lobes obscurely to often prominently toothed; (usually) 4 stamens perfected . . . . . . . . 10. B. deserticola

13. Small cushion-shaped shrublets, broader than tall; bracteoles lacking a distinct blade, with long patent marginal spines giving the bracteoles a ladder-like appearance; leaves to $2.6 \mathrm{~cm}$ long, margins always

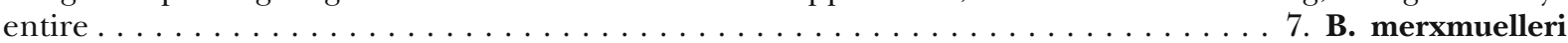
Perennial herbs or shrubs, usually taller than broad with stems erect or straggling; bracteoles with a narrow blade either side of the prominent midrib, with prominent marginal spines but not appearing ladder-like; leaves larger or if similarly small then margin often with spinulose teeth . . . . . . . . . . . . 14

14. Leaves at least $(3.4-) 4 \mathrm{~cm}$ long, papery, without a prominent apical spine, margin entire, leaves sometimes absent at fruiting stage $\ldots \ldots \ldots \ldots \ldots \ldots \ldots \ldots \ldots \ldots \ldots \ldots \ldots \ldots \ldots \ldots \ldots \ldots$. $\ldots \ldots \ldots \ldots$ 
Leaves up to $3.4 \mathrm{~cm}$ long, rather stiff, with a prominent apical spine and often with spinulose teeth along the

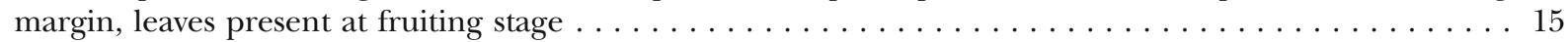

15. Indumentum of calyx and bracteoles predominantly eglandular-puberulous; posterior calyx lobe $17.5-24 \mathrm{~mm}$ long; bracteoles of mature flowers $19-29 \mathrm{~mm}$ long; leaves $1.6-3.4 \times 0.8-1.8 \mathrm{~cm} \ldots \ldots$. . . 3. B. jubata Indumentum of calyx and bracteoles predominantly glandular-puberulous; posterior calyx lobe $11-16 \mathrm{~mm}$ long; bracteoles of mature flowers $9.5-14(-18) \mathrm{mm}$ long; leaves $0.7-2.4 \times 0.25-1 \mathrm{~cm}$. . 4. B. meeuseana

16. Corolla markedly zygomorphic, the two adaxial lobes lanceolate and fused in the lower third; inflorescence viscidglandular, spiciform with markedly reduced bracts; stigma subcapitate, to $0.3 \mathrm{~mm}$ long. . . . . . . . . 19. B. namba Corolla only weakly zygomorphic, the two adaxial lobes elliptic, not fused in lower third; inflorescence with glandular hairs sparse or absent, not viscid, cymes often clustered towards stem apices but not forming a welldefined spike, bracts foliaceous; stigma linear or clavate, $0.8-2 \mathrm{~mm}$ long $\ldots \ldots \ldots$

17. Outer calyx lobes ovate, abruptly widened into a rounded, truncate or subcordate base; mature leaves with

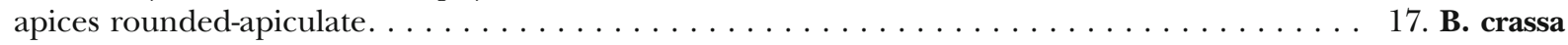
Outer calyx lobes elliptic or obovate, base cuneate or attenuate; mature leaves with apices acute-

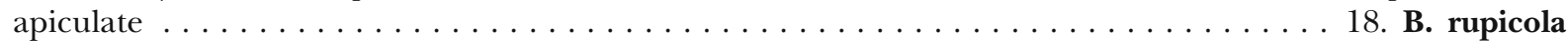

18. Corolla white throughout, with a very long narrowly cylindrical tube, $(80-) 100-130 \mathrm{~mm}$ long, extending well

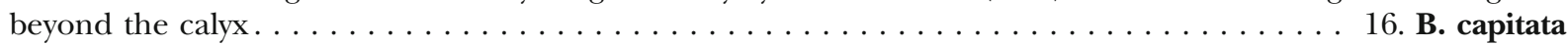
Corolla limb variously pink, lilac, pale blue to purple or rarely white, tube $18-30 \mathrm{~mm}$ long, mostly enclosed

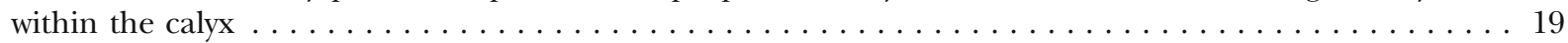

19. Bracteoles and calyces with entire or at most minutely and inconspicuously toothed margins; anthers held at corolla mouth or only shortly exserted, staminal filaments $8-12.5 \mathrm{~mm}$ long . . . . . . . . . 15. B. macrostegia Bracteoles and at least the posterior calyx lobe with conspicuously spinose or spinulose-serrate margins; anthers

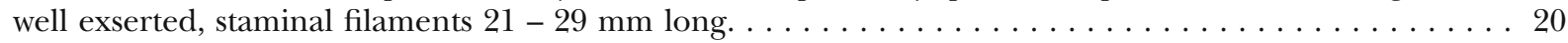

20. Leaves with mixed long ascending or subappressed hairs and interspersed short fine spreading hairs when young, blade not appearing grey-green, with $5-7$ pairs of lateral veins prominent beneath; outer calyx lobes with a prominent spinulose-serrate $\operatorname{margin} \ldots \ldots \ldots \ldots \ldots \ldots \ldots \ldots \ldots \ldots \ldots \ldots \ldots$. carruthersiana Leaves with dense short appressed white hairs at least when young, blade appearing pale grey-green, lateral veins indistinct; only the posterior calyx lobe with a conspicuously spinose margin, anterior lobe entire or minutely toothed, often with few short spines towards base . . . . . . . . . . 14. B. lichtensteiniana

21. Plant a rhizomatous perennial to $10 \mathrm{~cm}$ tall with subrosulate leaves; corolla tube cylindrical, limb in "2+3"

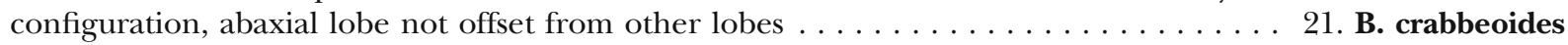
Plants considerably larger perennial herbs, shrubs or climbers, leaves not subrosulate; corolla tube campanulate or funnel-shaped above insertion point of stamens, limb in " $4+1$ " configuration, abaxial lobe

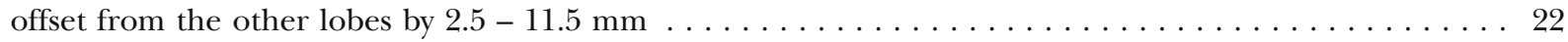

22. Anthers and stigma long-exserted, held well beyond the corolla lobes, staminal filaments $35-65 \mathrm{~mm}$

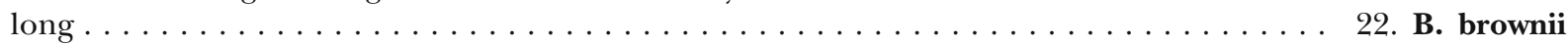
Anthers and stigma not or only slightly held beyond corolla lobes, staminal filaments $19-27 \mathrm{~mm}$ long. . . . . 23

23. Inflorescences crowded terminal spikes; outer calyx lobes lanceolate to elliptic, 4.5 - 6 mm wide with cuneate base, densely pubescent with silky buff to yellow-buff hairs; corolla $35-42 \mathrm{~mm}$ long . . . . . . . . . . . 23. B. villosa Inflorescences axillary, single-flowered; outer calyx lobes broadly ovate, 16 - 23 mm wide with cordate or rounded base, glabrous except along margin and scattered hairs on main veins; corolla $42-48 \mathrm{~mm}$

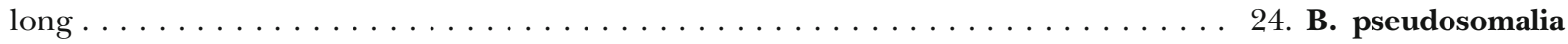

1. Barleria carruthersiana S. Moore (1880: 270); Clarke (1899: 154); Hiern (1900: 815); Klopper et al. (2006: 4); Makholela (2008: 21). Type: Angola, "Dist. Bumbo, prope Quitibe de Cima”, fl. Oct. 1859, Welwitsch 5040 (lectotype BM! [BM000931121]; isolectotypes K! [K000394521], LISU! [LISU223395]).

Barleria elegans sensu Benoist (1950: 15), pro parte quoad Exell Eं Mendonça 3100, non S. Moore ex C. B. Clarke.

Much-branched perennial herb or subshrub, 30 - $150 \mathrm{~cm}$ tall; stems quadrangular when young, either with two lines of short white spreading to retrorse hairs on the uppermost internodes only or these hairs more numerous and widespread, also with sparse long ascending buff-coloured hairs with a \pm bulbous base. Leaves often immature at flowering, blade elliptic or ovate, $3.7-17.5 \times 1.7-8 \mathrm{~cm}(\mathrm{l}: \mathrm{w}$ ratio $2-2.8: 1$ ), base attenuate and sometimes forming a wing along distal potion of petiole, uppermost leaves more rounded, margin entire, apex acute to attenuate or rarely obtuse, mucronate, surfaces with \pm long ascending or subappressed hairs most dense on the veins beneath and margin, interspersed with short fine spreading hairs when young; lateral veins $5-7$ pairs, prominent beneath; petiole 
to $10 \mathrm{~mm}$ long. Inflorescences axillary, contracted, \pm strobilate unilateral cymes $2-7.5 \mathrm{~cm}$ long, typically $7-15$-flowered; bracteoles imbricate and enclosing the base of the calyces, green, ovate or lanceolate, pairs unequal, the larger $11-30$ $\times 5.5-13 \mathrm{~mm}$, margin spinulose-serrate, apex attenuate and often somewhat falcate, spine-tipped, surface tripliveined and with prominent reticulate secondary venation, main veins and margin with appressed to ascending long hairs, surface with short spreading hairs and usually with sessile or short-stalked broad glands proximally, with or without scattered glandular hairs. Calyx scarious, brown or mauve-brown, somewhat accrescent; anterior lobe broadly ovate or suborbicular, $15.5-18 \times 12-$ $15.5 \mathrm{~mm}$ in flower, up to $22 \mathrm{~mm}$ long in fruit, base shallowly cordate or rounded, margin spinulose-serrate throughout, apex obtuse, rounded or shortly bifid in profile but serrated, surface with long ascending or appressed hairs along main veins and with short fine spreading hairs elsewhere, with or without numerous short glandular hairs, palmate-reticulate venation prominent; posterior lobe like anterior lobe but $16.5-22 \times 12.5-18 \mathrm{~mm}$ in flower, up to $25.5 \mathrm{~mm}$ long in fruit, apex \pm attenuate into a short spine; lateral lobes linear-lanceolate, 10.5 - 13 mm long. Corolla 37 - $50 \mathrm{~mm}$ long, lilac or pale blue, eglandular-pubescent externally and lateral lobes also with scattered glandular hairs; tube 19.5 - $30 \mathrm{~mm}$ long, cylindrical but expanded towards mouth; limb in weak " $4+1$ " configuration; abaxial lobe offset by $2-3.5 \mathrm{~mm}$, broadly obovate or rounded, 15 $17.5 \times 10.5-19 \mathrm{~mm}$, apex rounded or obtuse, lateral lobes (oblong-) obovate to elliptic, $14-18.5 \times 8-12 \mathrm{~mm}$, apices rounded or obtuse, adaxial lobes as lateral lobes but $6.5-$ $10 \mathrm{~mm}$ wide. Stamens inserted $9-15 \mathrm{~mm}$ from base of corolla tube; filaments 23 - $29 \mathrm{~mm}$ long; anthers exserted, (2.5 -) 3- $4 \mathrm{~mm}$ long; lateral staminodes 2.5 - $4 \mathrm{~mm}$ long, pubescent in proximal portion, antherodes well developed, $0.75-1 \mathrm{~mm}$ long. Ovary with ring of dense minute crisped white hairs at attachment point of style and sometimes with few long white hairs towards apex; stigma clavate, 0.5 $0.75 \mathrm{~mm}$ long. Capsule 4-seeded, $15-16 \mathrm{~mm}$ long, glabrous; seeds c. $4.5-5 \mathrm{~mm}$ long and wide. Fig. $1 \mathrm{~A}-\mathrm{C}$.

DISTRIBUtION. Endemic to Angola (Benguela, Cuanza Sul, Huila, Malange and Namibe provs.). Map 6.

ADDITIONAL SPECIMENS EXAMINED. ANGOLA. Chella Mts, fl. Sept. 1883, Johnston s.n. (K!); km 77 on the Benguela - Katanga railway, fl. 2 June 1909, Pearson 2125 (BOL!, K!); between Lobito Bay and Hauha, with old infl., 6 March 1927, Lynes s.n. (BM!); Benguela, Lobito, near the lighthouse, fl. 27 June 1937, Exell Eे Mendonça 3100 (BM!); environs de Lobito, fl. Aug. 1937, Humbert 16064 (BM!, P); Benguela Distr., Lobito, SE of bay, fl. \& fr. 28 Sept. 1937, Milne-Redhead 2513 (K!); a 106 km de Novo Redondo - Lobito, fl. 6 March 1967, Teixeira et al. 11075 (LISC!); Moçâmedes, Lucira, nas margens do R. Camucuio, fl. \& fr. 5 Aug. 1967, Menezes et al. 3026 (LISC!, LUBA!); Benguela, entre
Sousa Lara e o Lobito, a $31 \mathrm{~km}$ do Lobito, fl. 19 July 1969, Barbosa 11730 (K!, LISC!, PRE!); Malange Distr., andados $21 \mathrm{~km}$ de Cacuso para Malange, fl. 15 July 1970, Raimundo et al. 322 (LISC!); Novo Redondo - Lobito, km 27, fl. 31 March 1973, Bamps E Martins 4352 (BR, K!, LISC!, WAG*); 18 km N of Campanda between Benguela and Lubango, fl. 8 April 2017, Tripp EF Dexter 6910 (COLO!, K!, LUBA!). HABITAT \& ECOLOGY. Barleria carruthersiana occurs in the arid to semi-arid coastal plain of south and central Angola but with one outlier population in Malange Province at higher elevation. It is recorded from dry stony hillslopes, including on calcareous substrates, and from riverine scrub; it is usually found in the open amongst grass, sclerophyllous shrubs or open dry woodland of, for example, Commiphora-Adansonia, and has also been recorded from roadsides; 40 - 1100 m elevation.

CONSERVATION STATUS. This species is a rather localised Angolan endemic, primarily found along the broad coastal lowlands between Sumbe and Namibe. It has an EOO of $63,370 \mathrm{~km}^{2}$. The outlier population in Malange seems to be anomalous as this area receives higher rainfall and is also at a higher elevation, but we have no particular reason to doubt the accuracy of the specimen label of F. Raimundo et al. 322. This species was recorded as common along the lower stretch of the BenguelaKatanga railway by $\mathrm{H}$. Pearson. It has most often been collected from the vicinity of Lobito, where populations are likely to have declined due to the continued expansion of this port town. In the most recent collection of this species (Tripp E Dexter 6910) near Campanda, the local population comprised only a solitary plant. However, it is almost certainly underrecorded in other areas of the coastal lowlands due to limited collecting effort. It is therefore provisionally assessed as Data Deficient - DD with more information on its range and threats required.

NOTES. Whilst this species is very easily recognised based on gross morphology, there is considerable population-level variation. Plants from the Lobito area lack glandular hairs on the bracteoles and outer calyx lobes (except for one of the two pieces on Humbert 16064 at BM) whilst these are present at all other localities. Some populations, including the type gathering, have a rather dense short stem indumentum whilst this is sparse and restricted to the uppermost internodes in most collections. There is also considerable variation in the corolla size and in particular the length of the tube but this is not correlated with the variation in indumentum. Further material is desirable to explore this variation further.

2. Barleria elegans S. Moore ex C. B. Clarke (1899: 154); Hiern (1900: 815); Clarke (1901: 49); Obermeyer (1933: 154); Benoist (1950: 15), pro parte excl. Exell E๊ Mendonça 3100; Meyer (1968: 16); Balkwill \& 

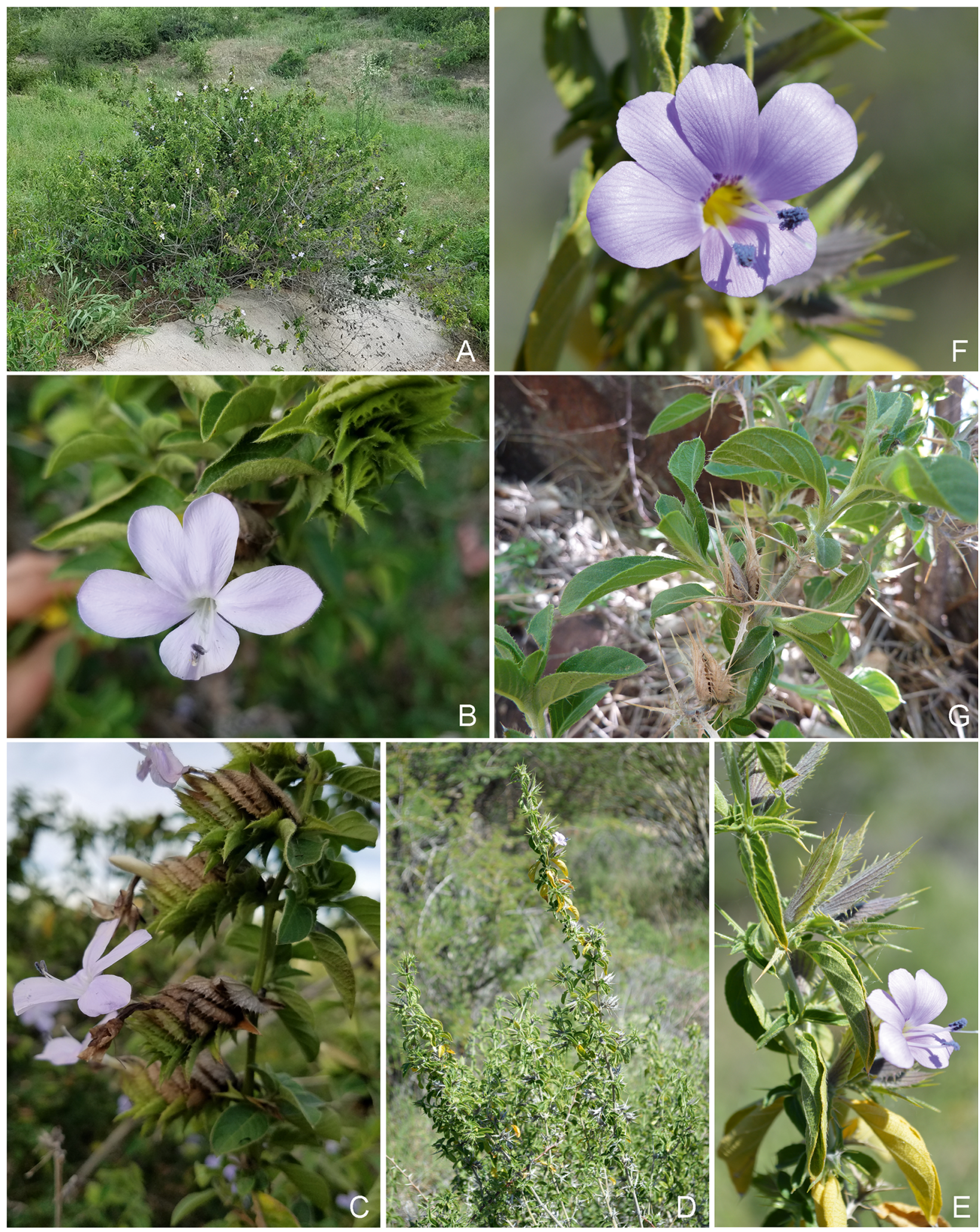

Fig. 1. A - C Barleria carruthersiana. A habit; B flower; C inflorescences. D - G B. jubata. D habit; E inflorescences; F flower; G foliage and old inflorescences. A - C Tripp \& Dexter 6910 (Angola); D - F Nyatoro et al. 36 (Namibia); G Tripp \& Dexter 4126 (Namibia). PHOTOS: A - C, G E. A. TRIPP; D - F I. DARBYSHIRE. 
Balkwill (1997: 555, Figs. 2E, 6A, 7H \& J); Craven (1999: 152); Welman (2003: 93); Klopper et al. (2006: 4); Makholela (2008: 21); Darbyshire et al. (2012: 765); Klaassen \& Kwembeya (2013: 129); Darbyshire (2015: 45); Singh et al. (2015: pl. 2316, 137). Type: Angola, Loanda Distr., fl. \& fr. 1858, Welwitsch 5068 (lectotype BM! [BM000931064], selected by Darbyshire (2015); isolectotypes C* [C10000003], K! [K 000394523 ], LISU! [LISU223390], P* [P00434404]). Additional original syntypes: Angola, Distr. de Cazengo, Muxaûlo, fl. June 1855, Welwitsch 5114 (BM! [BM001121075], LISU! [LISU223392]); without locality \& date, fr., Welwitsch 5122 (BM! [BM001252129], LISU! [LISU223394]); Distr. Loanda, fl. May - June 1858, Welwitsch 5187 (BM! [BM0 01121074 ], K! [K000394522], LISU! [LISU223393]); inter Bumbo et Bruco, fr. Oct. 1859, Welwitsch 5034 (BM! [BM001252128], LISU! [LISU223391]); Ambriz, fl. March 1873, Monteiro E Monteiro s.n. (K! [K000394524]); Loango, rand des Bengwahls nordl. am [?]Chinchoro, fl. 13 April 1874, Soyaux 26 (K! [K000394479], M! [M0242131]); Huilla-Humpata, fl. \& fr. Sept. 1883, H. H. Johnston s.n. (K! [K001009510]).

Spiny perennial herb or subshrub, often straggling, 40 $150(-300) \mathrm{cm}$ tall; stems sparsely strigose, with or without two opposite lines of short white retrorse hairs when young, later glabrescent. Leaves sometimes absent at flowering / fruiting, blade papery, (ovate-) elliptic to narrowly so, $(3.4-) 4-13 \times(1.5-)$ $2-5 \mathrm{~cm}$ (1:w ratio $1.9-3: 1)$, base attenuate, cuneate or uppermost leaves obtuse, margin entire, apex obtuse to acuminate, apiculate or uppermost leaves mucronulate, surfaces strigose, hairs most numerous on or restricted to midrib, margin and veins beneath; lateral veins (4-) 5 - 9 pairs; petiole to $25 \mathrm{~mm}$ long. Inflorescences axillary, contracted unilateral cymes, 1.5 - $6 \mathrm{~cm}$ long, (3 -) 5 - 20-flowered; bracteoles green, (linear-) lanceolate, $(9-) 11-23 \times 2-5 \mathrm{~mm}$ excluding the (1-) $3-8$ prominent marginal spines per side, each $1-6.5 \mathrm{~mm}$ long, apex spinose, surface tripliveined with pale prominent midrib, often with scattered broad sessile glands towards base, surfaces sometimes glandular- and/or eglandular-puberulous; paired sterile bracteoles sometimes present at lower nodes. Calyx green or brown-green, sometimes with paler margin, tardily turning pale-scarious; anterior lobe elliptic or elliptic-lanceolate, $9.5-17.5 \times 3.5-7$ $\mathrm{mm}$, margin with $4-9$ flexuose lateral spines per side $1.2-6.5 \mathrm{~mm}$ long ending in a short bristle, apex spinose or bispinose, external surface sparsely strigose, sometimes also sparsely to densely glandularand/or eglandular-puberulous; posterior lobe like anterior lobe but $11-23 \times 4-9 \mathrm{~mm}$, marginal spines up to $9 \mathrm{~mm}$ long, apex attenuate-spinose; lateral lobes linear-lanceolate, 6.5 - $13.5 \mathrm{~mm}$ long. Corolla
(22 -) 27 - $44 \mathrm{~mm}$ long, white, lilac, bluish or mauve, eglandular-pubescent externally, with or without few glandular hairs on limb; tube 14 - $25 \mathrm{~mm}$ long, cylindrical, narrowly widened towards mouth; limb in weak " $4+1$ " configuration or subregular; abaxial lobe offset by $1-4.5 \mathrm{~mm}$, obovate or rounded, $8-18 \times 6$ - $12.5 \mathrm{~mm}$, apex rounded, obtuse or shallowly emarginate; lateral lobes as abaxial lobe but elliptic or obovate, $5.7-9.5 \mathrm{~mm}$ wide, apex rounded to subattenuate; adaxial lobes narrower, 4.5 - $8 \mathrm{~mm}$ wide. Stamens inserted 9-12 $\mathrm{mm}$ from base of corolla tube; filaments 16 - $23.5 \mathrm{~mm}$ long; anthers 2.1 - $3.6 \mathrm{~mm}$ long; lateral staminodes $1.5-5.5 \mathrm{~mm}$ long, pubescent or sparsely so, antherodes 0.5 $1.3 \mathrm{~mm}$ long. Ovary with a ring of minute crisped white hairs at attachment point of style; style glabrous; stigma linear or clavate, $0.4-0.9 \mathrm{~mm}$ long. Capsule 4-seeded, (11 -) 13 - $16.5 \mathrm{~mm}$ long, glabrous or with white ascending hairs towards apex; seeds 4.2 $-5 \mathrm{~mm}$ long and wide.

Barleria elegans S. Moore ex C. B. Clarke subsp. elegans Barleria pungens L. var. macrophylla sensu Moore (1880: 269), pro parte quoad Welwitsch 5034, 5068, 5114, 5122 \& 5187; non Nees (1847: 237).

Anterior and posterior calyx lobes sparsely to (often) densely glandular- and/or eglandularpuberulous in addition to the strigose hairs along the veins. Corolla lilac to bluish or mauve, rarely white? (see note).

DISTRIBUtION. Angola (Bengo, Cuanza Norte, Cuanza Sul, Cunene, Huila, Luanda and Namibe Provs,), Northern Namibia (Kunene/Omusati region, ?Oshikoto region - see notes). Map 1.

ADDITIONAL SPECIMENS EXAMINED. ANGOLA. An der Chitandamündung, fl. 28 May 1900, Baum 951 (BM!, K!, M!, Z*); between Gambos Fort and Mission Station, fl. 15 May 1909, Pearson 2463 (K!); between Gambos Mission Station and Cahama, fl. 17 May 1909, Pearson 2472 (K!); CasalCastendo, fl. \& fr. 18 April 1922, Dawe 386 (K!); Humbe am Kunene, fl. \& fr. June 1936, Boss s.n. (M!); Luanda, R. Dande, Mabubas, fl. 24 March 1937, Exell E Mendonça 43 (BM!); Mossamedes, Tampa, fl. \& fr. 1 June 1937, Exell E Mendonça 2404 (BM!); Huíla, Ungueria, in bud 2 June 1937, Exell Eं Mendonça 2450 (BM!); Huíla, R. Cunene, Ruacaná, fl. 9 June 1937, Exell E̋ Mendonça 2799 (BM!, P*); Cuanza Sul, Cabuta, fl. 25 June 1937, Exell E Mendonça 3083 (BM!); Serra da Chela, Humbia, Bibala, fl. 8 Aug. 1941, Gossweiler 13186 (LUBA!); Luanda Distr., Escarpa do Bairro do Saneamento, fl. 25 May 1955, Cristovão Henriques 597-Fl. (PRE!); Posto Zootécnico 


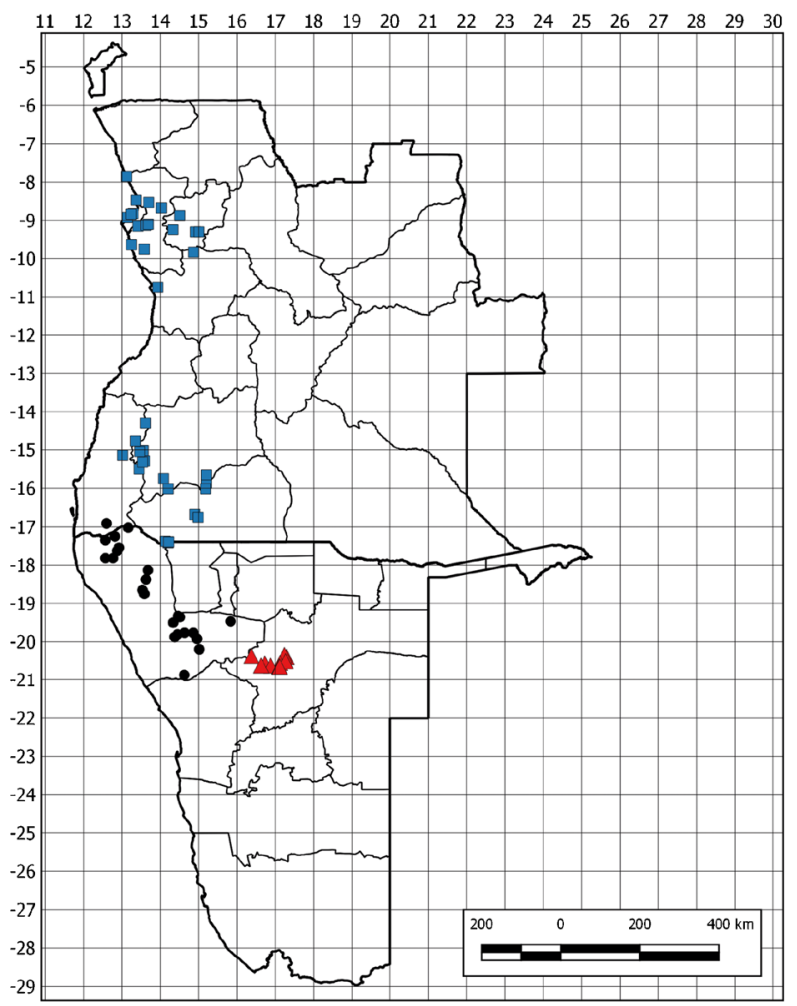

Map 1. Distribution of Barleria elegans subsp. elegans (blue squares), B. jubata (red triangles) and B. meeuseana (black circles).

de Quilengues, fl. \& fr. July 1956, Teixeira 1252 (LUBA!); Luanda, próx. de Catete, fl. 8 April 1958, Monteiro et al. 42 (BM!, LUBA!); Caxito, praia de S. Tiago a caminho do Dande, fl. 8 May 1958, Monteiro et al. 120 (BM!, PRE!); Moçamedes, Bibala, Caitou, fl. \& fr. 17 June 1959, Teixeira E Andrade 4044 (LUBA!); top of Ruacana Falls on Angolan side, fl. 29 April 1962, Rycroft 2408 (WIND!); idem, fl. 30 April 1962, Rycroft 2445 (WIND!); Moçamedes, Bibala, Lungo, Mungaunga, old infl. 13 Oct. 1962, Henriques $\mathcal{E} \mathcal{F}^{2}$ Moreno 22 (BM!, LUBA!); Moçamedes, Lola, fl. 25 Oct. 1962, Henriques $\mathcal{E}^{\circ}$ Moreno 66 (BM!, LUBA!); Luanda, entre Corimba e Marro dos Veados, fl. \& fr. 9 Aug. 1963, Mendes dos Santos 1167 (BM!); Huíla, Mulondo entre a povoação e o rio Cunene, fl. \& fr. 12 Sept. 1963, Barbosa 10759 (BM!); Huíla, Alto Cunene, Mulondo, na picada para Quiteve ao $\mathrm{km} \mathrm{24,} \mathrm{fl.} \mathrm{\&}$ fr. 20 Sept. 1963, Azancot de Menezes 779 (K!, $\mathrm{P}^{*}$, SRGH!); Cuamato, margem esquerda do R. Cunene a $1.5 \mathrm{~km} \mathrm{du} \mathrm{Vila} \mathrm{Roçadas,} \mathrm{fr.} 15$ Nov. 1963, Gouveia 775 (LUBA!); Cuanza Norte, Salazar, fr. 10 Aug. 1965, da Silva 1429 (LUBA!); Cuanza Sul, Muceque Prenda, Porto Amboim, fl. 27 April 1967, Teixeira et al. 11548 (LISC!); Moçâmedes [Namibe], a $18 \mathrm{~km}$ do Munhino para Capangombe, fl. 6 July 1967, Gouveia E Correia 1349 (LUBA!); Cuanza Norte, a $10 \mathrm{~km}$ de Salazar para Malanje, fl. \& fr. 5
June 1970, Barbosa et al. 11905 (LISC!); Cuanza Norte, andados $13 \mathrm{~km}$ de Zenza para Golungo, fl. \& fr. June 1970, Raimundo et al. 197 (LISC!, SRGH!); Huíla, Chibia, ao km 16.5 da estrada Chibia-Hunguéria, fl. 6 May 1971, Borges 187 (LISC!, PRE!); Luanda Prov., Quiçama National Park, plateau near Cauá, fl. May 1972, Huntley 3109 (PRE!); Luanda, área do Golfo, fl. 18 May 1976, Daniel E Lourenço 991 (LUAI!); Luanda, Parque Nacional da Quiçama, fl. 3 May 1977, Daniel E Dala 1297 (LUAI!); Luanda, Catete, estrada para Quiminha do trajecto Calucala, fl. \& fr. 1 Aug. 1977, Daniel 1350 (LUAI!); Luanda, Calumbo, nos arredores da aldeia, na margem do R. Kwanza, fl. 6 May 1978, Batalha 552 (LUAI!); [Cuanza] Norte, entre Maria Tereza e Zenza, ao longo da estrada, picada para Golungo Alto, fl. 21 May 1978, Batalha 592 (LUAI!); Luanda, Quiçama, Relevé 50, fl. \& fr. 11 Sept. 1997, Cooper 181 (PRE!); Huíla, Lubango, R. Nalungula, Munhino, fl. \& fr. 18 May 1998, Daniel 2929 (LUBA!). NAMIBIA. Gaub [Ghaub], fr. April 1913, Dinter 2911 (PRE!) - see note; Kaokoland, Ruacana, near falls, fl. 29 April [March on M sheet] 1962, Kotze 24 (M!, WIND!); Ruacana, fl. 30 April 1962, Kotze 76 (M!, PRE!, WIND!).

HABITAT \& ECOLOGY. Barleria elegans subsp. elegans is recorded from dry bushland, thicket, dry forest including forest clearings, and from open plains, more rarely from more moist shaded areas including riverine woodland; $0-1500 \mathrm{~m}$ elevation. It occurs in the Colophospermum mopane and miombo woodland zones of Angola as well as semi-arid areas of the Angolan coastal lowlands. In Namibia, it occurs in the Western Highlands vegetation type of Mendelsohn et al. (2002).

CONSERVATION STATUS. This is the most frequently recorded species of Barleria in Angola where it is widespread in the west, apparently in two disjunct populations, the southern of which just extends into Namibia. It has an EOO of just under $200,000 \mathrm{~km}^{2}$. In view of this large range and apparent abundance, together with its rather varied habitat preferences, it is assessed as of Least Concern - LC. It is, however, very rare in Namibia where it is possibly restricted to the Ruacana Falls area of the Cunene River and it was not located there by the first author despite extensive searching in April 2015. At Ruacana, there has been some disturbance of suitable habitat associated with the hydro-electric dam and related infrastructure (Darbyshire et al. 2018). It should therefore be considered nationally threatened in Namibia under IUCN criteria B1 and B2 for national assessments.

NOTES. Barleria elegans is quite variable in Angola. Some populations have bracteoles and calyces with only short lateral spines, and these often have a densely glandular-hairy calyx. Other populations 
have much longer spines on the bracteoles and calyx and these can have a sparser calyx indumentum, sometimes with only eglandular hairs. However, these differences are not entirely consistent and the variation within the Angolan populations appears to be clinal and without clear geographic patterns. Daniel 2929 is recorded as having white flowers but in the dry state they look like they may have been coloured pink as in the rest of the material, and the calyx indumentum is typical of subsp. elegans.

It is not clear whether the disjunction within Angola is a true reflection of its distribution or is more a product of under-collecting in west-central Angola. However, it is also possible that Barleria elegans is replaced by B. carruthersiana in that region.

Dinter 2911, which undoubtadly represents Barleria elegans subsp. elegans, was collected from "Gaub" in Namibia; this is believed to be modern-day Farm Ghaub near Tsumeb in Oshikoto Region (1917BD). However, this locality falls well outside of the known range for this species and it seems unlikely that this species would occur so far east, hence this point is omitted from the distribution in Map 1.

The second subspecies, subsp. orientalis I. Darbysh. (Darbyshire 2015: 45) is disjunct from subsp. elegans, being recorded from Mozambique, Zimbabwe, eSwatini and northeast South Africa. This is the taxon illustrated in Singh et al. (2015: pl. 2316). It differs in usually having white corollas (rarely recorded as blue) and in always lacking the fine glandular and eglandular puberulous hairs on the calyx.

3. Barleria jubata S. Moore (1907: 229); Obermeyer (1933: 154); Meyer (1957: 380); Meyer (1968: 14), pro parte excl. Giess $\mathcal{E}$ Leippert 7588 [cited as 5588]; Craven (1999: 152); Welman (2003: 93); Klopper et al. (2006: 4); Darbyshire et al. (2012: 765); Klaassen \& Kwembeya (2013: 129); Nyirenda \& Balkwill (2018: 89). Type: Namibia, Damaraland, fl. 1879, Een s.n. (holotype BM! [BM000931094]).

Spiny shrub or shrublet, $60-150 \mathrm{~cm}$ tall, fertile branches sometimes straggling; stems rather stout, densely white-puberulous throughout, velutinous to the touch, with interspersed long ascending buff-coloured hairs with a \pm swollen base. Leaves obovate or elliptic, $1.6-$ $3.4 \times 0.8-1.8 \mathrm{~cm}$ (1:w ratio $1.7-2.1: 1)$, base attenuate or cuneate, margin entire or with small teeth formed by swollen and elongated hair bases, apex acute to rounded, prominently mucronate, veins beneath and margin strigose, elsewhere sometimes strigulose, young leaves also white-puberulous; lateral veins 4 6 pairs; petiole up to $7 \mathrm{~mm}$ long. Inflorescences axillary, contracted unilateral cymes up to $2 \mathrm{~cm}$ long, each 2 6-flowered; bracts foliaceous; bracteoles lanceolate- spinose, pairs somewhat unequal in length, the longer $19-29 \times 1.3-3 \mathrm{~mm}$, blade at first green or purplish but turning scarious, midrib pale and prominent, margin with $3-5 \pm$ patent lateral spines per side $3-$ $5.5 \mathrm{~mm}$ long, surface white-puberulous with occasional broad sessile glands proximally; sterile bracteoles persisting at lower nodes as paired or clustered axillary spines. Calyx at first green to mauve, soon turning palescarious; anterior lobe elliptic-lanceolate to lanceolate, 15 - $19 \times 4.5-6.2 \mathrm{~mm}$, base cuneate, margin with $6-8$ conspicuous slender spines per side to $3.5 \mathrm{~mm}$ long, apex spinose or the spine shortly notched, external surface white-puberulous particularly towards base, also buffyellow-strigose and with interspersed short patent glandular hairs; posterior lobe like anterior lobe but $17.5-24 \times 5$ - $7.5 \mathrm{~mm}$, apex long-spinose, margin with longer spines up to $6 \mathrm{~mm}$ long; lateral lobes linear-lanceolate, 9 12 mm long. Corolla c. 26 - 32 mm long, lilac or pale blue, with purple streaks in roof of throat, pubescent externally, limb with mixed eglandular and glandular hairs; tube $17-$ $21 \mathrm{~mm}$ long, cylindrical, somewhat or barely widened towards mouth; limb subregular, abaxial lobe slightly offset; lobes \pm broadly obovate, each with a minute acumen, abaxial and lateral lobes c. $9-11.5 \times 8-8.5$ $\mathrm{mm}$; adaxial lobes c. $10 \times 6.5 \mathrm{~mm}$. Stamens inserted in lower half of corolla tube; filaments c. 18.5 - $20 \mathrm{~mm}$ long; anthers 3.6- 4 mm long; lateral staminodes slender, $3.5-$ $4 \mathrm{~mm}$ long, pubescent only at base, antherodes absent. Ovary with a ring of dense minute crisped white hairs at attachment point of style and extending onto style base; stigma linear, $\pm 1 \mathrm{~mm}$ long. Capsule 4-seeded, c. 13 $13.5 \mathrm{~mm}$ long, glabrous; seeds c. $4.2 \mathrm{~mm}$ long and wide Fig. 1D - G.

DISTRIBUTION. Endemic to Northern Namibia (Kunene and Otjozondjupa regions). Map 1.

ADDITIONAL SPECIMENS EXAMINED. NAMIBIA. Waterberg, fl. April 1899, Dinter 358 (Z*); [Erongo Mts — see note], Okanjanda, fl. July 1916, Pearson 9895 (BOL, K!, SAM); Okosongomingo, Anacampseros Berg, Distr. Otjiwarongo, fl. \& fr. 11 June 1939, Volk 2249 (M!); Distr. Otjiwarongo, Waterberg slope, fl. 25 July 1939, Volk 2472 (M!); Otjiwarongo region, Farm Graslaagte, Ozondjacheberge, old infl. 28 Nov. 1953, H. E E E. Walter 283 (M!, WIND!); Klein Waterberg above Okosongomingo, fl. 15 July 1954, Schelpe 201 (BM!); Otjiwarongo Distr., Farm Tweekoppies, 13.9 miles S of Otjiwarongo on road to Okahandja, in bud 15 March 1955, de Winter 2739 (K!, PRE); Waterberg Plantation, $65 \mathrm{~km}$ E of Otjiwarongo, fl. 3 April 1968, H. E $H$. E. Wanntorp 641 (K!); Otjiwarongo. Upper slopes at SW point of the Omuverume plateau, fl. 22 April 1971, Rutherford 352 (WIND!); Okarakowisa N of Farm Bergtuine: OTJ 455, Waterberg Plateau, fl. 21 July 1972, Giess 12375 (M!, PRE, WIND!); Kunene, near house Tsaro on Farm Bergplaas No. 164, fl. 27 
June 1999, Noczil-Ostermeier NOC 1 (WIND!); Waterberg National Park, E side of mesa, fr. 26 Jan. 2013, Tripp E Dexter 4126 (COLO, K!, WIND); Otjiwarongo Distr., Waterberg Guest Farm, along the road to Waterberg plateau, fl. 19 April 2015, Nyatoro et al. 36 (COLO, K!, PRE!, WIND!).

HABITAT \& ECOLOGY. Barleria jubata can be found in sparse to dense Acacia-Terminalia bushland and dry woodland, often on rocky hillslopes of sandstone but also in shaded areas along dry streambeds; c. 1300 $1800 \mathrm{~m}$ elevation. It is recorded from the Thornbush Shrubland and transition to the Northern Kalahari vegetation types of Mendelsohn et al. (2002).

CONSERVATION STATUS. Barleria jubata has a highly restricted range, being found only on the sandstone outcrops of the Waterberg plateau and nearby hills in Otjozondjupa and adjacent areas of Kunene Region. It has an EOO of $2369 \mathrm{~km}^{2}$, and an AOO of $40 \mathrm{~km}^{2}$ using the recommmended $2 \times 2 \mathrm{~km}$ grid cell size; whilst the latter is likely to be an underestimate, it is very likely that $\mathrm{AOO}$ will be less than $2000 \mathrm{~km}^{2}$, this being the cut-off for the Vulnerable Category under IUCN criterion B2. It is known from $6-7$ threat-defined locations. It has previously been recorded as common by T. G. Een and relatively frequent by $\mathrm{H}$. \& E. Walter. The first author recently found it to be fairly common around the Waterberg Game Guest House on Klein Waterberg in 2015, although it appears to occupy a very restricted altitudinal range there, being found only towards the foot of the sandstone slope. B. Noczil-Ostermeier noted it as uncommon on its western-most location, where it was recorded as heavily browsed (by ?kudu). The Waterberg plateau is a National Park and so the species should be afforded some protection there. However, there has been severe encroachment into the bushland habitat around the foot of the Waterberg plateau and adjacent farmland (BirdLife International 2017); this is likely to impact populations of B. jubata, particularly those to the west of the National Park and around Klein Waterberg. With an inferred decline in extent and quality of habitat, this species is assessed as Vulnerable - VU $\mathrm{B} 1 \mathrm{ab}$ (iii) $+2 \mathrm{ab}$ (iii).

NOTES. Barleria jubata is somewhat intermediate in general appearance between $B$. elegans and B. meeuseana. The three are certainly close but easily separated by the characters given in the key. Barleria jubata is additionally separated by the dense, velutinous stem hairs which persist on the stout mature stems.

The K sheet of Pearson 9895 is labelled "Okanjanda" with "Erongo Mts" written separately, although in the same handwriting. The latter locality is likely to be incorrect, as this specimen is believed to be from current-day Okanjande near Otjiwarongo.
Nyirenda \& Balkwill (2018) included Barleria jubata in a phenetic analysis as part of their revision of the B. rigida-irritans-bechuanensis complex (see under sp. 5 below; Nyirenda 2012). They found that true B. jubata formed a well-defined cluster and that Giess $\mathcal{E}$ Leippert 7588, previously identified as B. jubata, was clearly differentiated from this cluster. This collection proved to be a misidentified specimen of $B$. damarensis (see sp. 11 below).

Meyer (1957: 380) noted that it is only found with certainty at the Great Waterberg and he postulated that this may be a tropical species that finds its southwest-most extent there, as is the case in a number of other tropical species. However, we now know Barleria jubata to be highly range-restricted, centred on the Waterberg area. This site is now known to contain a high plant diversity, with almost 500 species recorded, and it is recognised as an Important Plant Area (Smith 2005). It contains a number of range-restricted and rare species, including the endemic species Jamesbrittenia acutiloba (Pilg.) Hilliard (Scrophulariaceae), the endemic monotypic genus Dintera pterocaulis Stapf (Plantaginaceae) and the globally Vulnerable Lobelia hereroensis Schinz (Campanulaceae) (Loots 2005; Hilliard 1994).

4. Barleria meeuseana P. G. Mey. (1961: 59); Meyer (1968: 16); Craven (1999: 152); Welman (2003: 94); Klopper et al. (2006: 4); Darbyshire et al. (2012: 765); Klaassen \& Kwembeya (2013: 130). Type: Namibia, Ombepera, fl. 10 April 1957, de Winter Eं Leistner 5489 (holotype M! [M0109632]; isotypes PRE, WIND! [WIND000031675]).

Barleria merxmuelleri sensu Meyer (1957: 382), pro parte quoad Volk 2890; non P. G. Mey. sensu stricto.

Slender spiny shrub or shrublet, erect to straggling, 20 120 (-200) cm tall, rather slender; stems soon turning woody, sparsely to more densely white-puberulent, with interspersed long ascending buff-coloured hairs with a \pm swollen base. Leaves obovate, elliptic or lanceolate, $0.7-2.4 \times 0.25-1 \mathrm{~cm}$ (l:w ratio $1.6-$ 2.9:1), base cuneate to obtuse, margin usually with prominent spinulose teeth formed by swollen and elongated hair bases, apex acute or subattenuate to rounded, prominently mucronate, veins beneath and margin strigose, surfaces puberulous at least when young; lateral veins $3-4$ pairs; petiole $0-3 \mathrm{~mm}$ long. Inflorescences axillary, contracted unilateral cymes 1 $4 \mathrm{~cm}$ long, each (2 -) $4-8$ (- 20)-flowered; bracts foliaceous; bracteoles lanceolate-spinose, pairs somewhat unequal in length, the longer $9.5-14(-18) \times$ $0.5-1.3 \mathrm{~mm}$, blade at first green or pinkish but turning scarious, midrib pale and prominent, margin with $(1-) 2-4 \pm$ patent lateral spines per side $1.5-$ 
$3 \mathrm{~mm}$ long, surface glandular-puberulous, midrib often strigose; sterile bracteoles persisting at lower nodes as paired or clustered axillary spines. Calyx at first green to mauve, soon turning pale-scarious; anterior lobe lanceolate to narrowly so, $10-14 \times 1.8$ - $3.7 \mathrm{~mm}$, base cuneate, margin with 2 - 6 slender spines per side $1.5-4 \mathrm{~mm}$ long, apex spinose or bispinose, external surface glandular-puberulous, densely so when young, with or without interspersed short patent eglandular hairs, veins strigose; posterior lobe like anterior lobe but $11-16 \mathrm{~mm}$ long, apex long-spinose; lateral lobes linear-lanceolate, 7.5 $10 \mathrm{~mm}$ long. Corolla 22.5 - $28 \mathrm{~mm}$ long, lilac, pale blue or mauve, fading to white, with deep mauve markings in roof of throat; pubescent externally, lateral lobes of limb with mixed short eglandular and long glandular hairs; tube 13 - $16.5 \mathrm{~mm}$ long, cylindrical, barely widened towards mouth; limb subregular but with abaxial lobe offset by $2-2.5$ $\mathrm{mm}$; abaxial lobe obovate to broadly so, $8-10.5 \times 5.5$ - $7 \mathrm{~mm}$, apex rounded or slightly emarginate; lateral lobes obovate to elliptic, $6.5-11 \times 5-6.5 \mathrm{~mm}$, apex rounded or obtuse; adaxial lobes like laterals but $4-$ $5 \mathrm{~mm}$ wide, apex acute to rounded. Stamens inserted \pm midway along corolla tube; filaments c. $13-20 \mathrm{~mm}$ long; anthers 1.7 - $2.2 \mathrm{~mm}$ long; lateral staminodes 1 $2.5 \mathrm{~mm}$ long, pubescent only at base, antherodes well developed, $0.7-1 \mathrm{~mm}$ long. Ovary with a ring of dense minute crisped white hairs at attachment point of style; style glabrous; stigma linear, $0.5-1 \mathrm{~mm}$ long. Capsule 4-seeded, 9.5 - 13 mm long, glabrous; seeds 3.7 $-4 \times 3.2-3.4$ mm. Fig. $2 A-D$.

DISTRIBUTION. Southwestern Angola (Namibe prov.); Northwestern Namibia (Kunene region). Map 1.

SELECTED SPECIMENS EXAMINED. (Total of 23 collections seen): ANGOLA. Parque Nacional do Iona, Chamalinde Mts, fl. \& fr. 21 Jan. 2009, Winter 7716 (PRE!). NAMIBIA. Kapupa Valley, fl. \& fr. 19 Aug. 1956, Story 5874 (BM!, K!, PRE); Farm Mispah, OU 524, fr. 12 April 1964, Giess E Barnard 7907 (M!, WIND!); Outjo Distr., Farm Uitkoms (525), fl. 12 April 1964, Nordenstam 3691 (M!); Kaokoveld, Baynesberge, in Bergschlucht bei Quelle Okonbambi, fl. \& fr. 16 June 1965, Giess 8983 (M!, PRE, WIND!); Kaokoveld, Gesteinsränder nahe Okahua R., fr. 13 Sept. 1968, Giess 10514 (M!, PRE, WIND!); Kaokoveld, Oberlauf des Otjinjange-Riviers östlich vom Van-Zyl-Pass, fr. 5 July 1969, Meyer 1251 (M!, PRE, WIND!); Etosha N.P., Kaross-Soutputs, fl. 30 April 1975, le Roux E Jankowitz 1488 (WIND!); $136 \mathrm{~km} \mathrm{E}$ of Orupembe on road to Opuwo, fl. \& fr. 18 March 1992, Jacobsen 3574 (WIND!); Kunene Region, $1.5 \mathrm{~km}$ hillside Kaokofontein - solar pump on Hobatere, fl. 8 April 1999, Loutit 593 (WIND!); Khorixas Distr., c. $10 \mathrm{~km} \mathrm{~W}$ of Anker school, N of Kakatswa R., fl. \& fr. 8 June 2004, Kolberg \& Loots
HK1384 (K!, WIND!); Kunene Region, Etosha N.P., Farm Kaross 237, S of house, fl. \& fr. 23 April 2006, Berriman \& Kötting BER2/174 (WIND!); Vryheid Farm, on D2667, c. $6 \mathrm{~km} \mathrm{~W}$ of C35 highway, fl. \& fr. 18 Aug. 2011, Tripp E Dexter 1953 (CAS!, K!, MO!, NY!, RSA!, US!, WIND!); c. $21 \mathrm{~km} \mathrm{~S}$ of Etengwa, fr. 16 Jan. 2013, Tripp et al. 4069 (COLO!, K!, WIND!); Khorixas Distr., between Kamanjab and Fransfontein road, fl. \& fr. 19 May 2014, Nanyeni et al. 875 (COLO!, K!, PRE!, WIND!).

HABITAT \& ECOLOGY. Barleria meeuseana occurs in woodlands and wooded areas that are transitional to savannas. It commonly occurs on rocky slopes and outcrops (koppies) of granite or dolomite, growing amongst boulders or in rock crevices in dry open bushland of Acacia, Commiphora, Colophospermum mopane, Boscia and Adenolobus; it is also recorded from dry stony riverbeds; $800-1475 \mathrm{~m}$ elevation. It is restricted to the Kaokoveld Centre of plant endemism (sensu van Wyk \& Smith 2001). In Namibia, it occurs primarily in the Western Highlands vegetation type of Mendelsohn et al. (2002).

CONSERVATION STATUS. This species has a rather narrow range in the Kaokoveld Centre of Endemism, with an EOO of $56,265 \mathrm{~km}^{2}$. It has only very recently been discovered in Angola and was previously thought to be a Namibian endemic (Darbyshire et al. 2012). It has been recorded as locally common or abundant by several plant collectors, and was found by the first author to be frequent in the dolomite ridge north of Fransfontein. Much of its range falls within communal livestock farming areas and there is a possible impact to some populations from high browsing pressure from goats. However, it is not considered to be globally threatened and is assessed as of Least Concern - LC.

NOTES. The glandular hairs on the calyces of the type specimen are less dense than is usual for this species; this is also the case on the single Angolan specimen seen. Story 5874 is unusual in having up to c. $12-20$ flowers per cyme, compared to a maximum of c. 8 flowers in the other material seen.

This species is sometimes beset with characteristic galls, these being pyriform and densely hirsute with bright green to golden hairs (Fig. 2B).

5. Barleria rigida Nees (1847: 242); Obermeyer (1933: 153); Meyer (1957: 384; 1968: 16); Balkwill \& Balkwill (1997: 557, Figs. 3C and 9C 7 ); Craven (1999: 152); Welman (2003: 94); Klopper et al. (2006: 4); Darbyshire et al. (2012: 765); Mannheimer (2012: 372); Nyirenda (2012: 205); Klaassen \& Kwembeya (2013: 130); Darbyshire (2015: 49). इ Barleria irritans Nees var. rigida (Nees) C. B. Clarke (1901: 48), pro parte excl. Schinz 3. Type: "Africa australi extratropical", without specific locality, without date, 

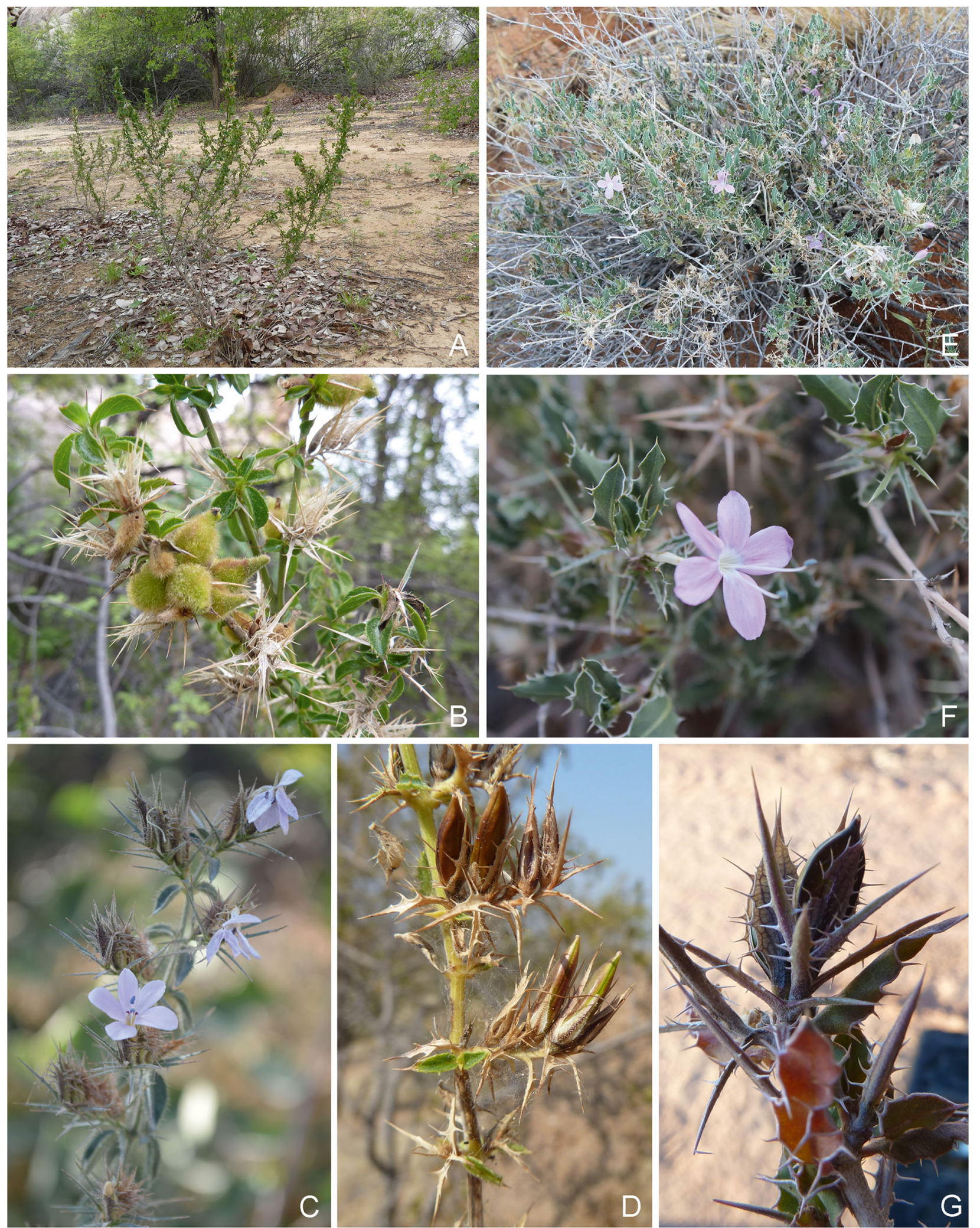

Fig. 2. A - D Barleria meeuseana. A habit; B characteristic galled inflorescences; C flowering branch; D fruiting branch. E - G B. rigida var. ilicina. E habit; F flower; G fruiting branch. A \& B Tripp 4069 (Namibia); C Nanyeni et al. 875 (Namibia); D Tripp \& Dexter 1953 (Namibia); E \& F South Africa; G Tripp \& Dexter 2038 (Namibia). PHotos: A, B, D, G E. A. TRIPP; C I. DARBYSHIRE; $\mathbf{E} \& \mathbf{F}$ W. FRONEMAN. 
Hoffmannsegg in herb. Willdenow 11660 (lectotype B$\mathrm{W}^{*}$ [B-W11660-010], selected here). Additional original syntypes: South Africa, Grootriviers Poort, fl., without date, Burchell 1991 (syntype G-DC, isosyntype K! [K000794967]); Grootriviers Poort, Lichtenstein s.n. (syntype B, presumed $\dagger$ ).

Barleria stimulans E. Mey. ex Nees var. macracantha Nees (1847: 241), pro parte quoad Burchell 1621 [no. not cited in protologue].

Spiny shrublet, 5 - $45 \mathrm{~cm}$ tall, much-branched, leafy stems erect, spreading or trailing; stems retrorsely whitepuberulent mainly or exclusively in two oppositedecussate bands, nodes often strigose. Leaves rather coriaceous, blade variable, broadly oblong to narrowly oblong-elliptic or -lanceolate, $0.8-4.3 \times 0.2-1.1 \mathrm{~cm}(\mathrm{l}: \mathrm{w}$ ratio $1.6-6.9: 1$ ), base cuneate or truncate, margin whitecartilaginous, sinuate, with or without marginal spines, these can be harsh and up to $4 \mathrm{~mm}$ long, apex acute and apiculate or spinose, surfaces glabrous or sparsely yellowstrigose at least along the midrib beneath, sometimes also minutely puberulent when young; lateral veins indistinct, midrib prominent beneath; petiole $0-5 \mathrm{~mm}$ long. Inflorescences axillary, contracted unilateral cymes 1 $2.5 \mathrm{~cm}$ long in the upper axils, each $2-10$-flowered or flowers solitary; bracteoles green with white margin and midrib or whitish throughout, linear-lanceolate or lanceolate, $10-29 \times 1-6 \mathrm{~mm}$, base cuneate or parallel, margin with $2-18$ spines per side of variable length (see varieties) or margin rarely entire, apex long-spinose. Calyx \pm coriaceous, at first pale green to brown-green or pinkish, often with whitish margin and base, sometimes also with contrasting darker venation, sometimes later turning whitish throughout; anterior lobe elliptic, (oblong-) ovate or lanceolate, $9.5-22 \times(3-) 3.7-9 \mathrm{~mm}$, base attenuate, margin with (1-) 3-20 lateral spines per side $0.2-5.7 \mathrm{~mm}$ long ending in a stiff bristle, apex spinose or bifidly so, surface sparsely strigose and sparsely puberulent or glabrous, palmate-reticulate venation \pm prominent; posterior lobe as anterior lobe but $10-28.5 \times(3.2-) 4-9.5 \mathrm{~mm}$, apex attenuate into a long spine; lateral lobes linearlanceolate, 5.5 - $11 \mathrm{~mm}$ long. Corolla 25 - $38.5 \mathrm{~mm}$ long, white, pink, pale blue or violet, pubescent externally with mixed glandular and eglandular hairs or rarely only eglandular hairs; tube 15 - $22 \mathrm{~mm}$ long, cylindrical, narrowly campanulate towards mouth; limb subregular; abaxial lobe obovate (-elliptic) $8-16 \times 6.5-11 \mathrm{~mm}$, apex rounded or emarginate; lateral lobes as abaxial lobe but 8 $14 \times 5-8.5 \mathrm{~mm}$; adaxial lobes $8.5-15 \times 4-8 \mathrm{~mm}$. Stamens rather long-exserted, inserted at or shortly above midway along corolla tube; filaments 16.5 - 24 mm long; anthers 1.4 - $2.6 \mathrm{~mm}$ long; lateral staminodes $1-2.7 \mathrm{~mm}$ long, pubescent at base, antherodes $0.3-0.9 \mathrm{~mm}$ long. Ovary with a ring of minute crisped white hairs at apex and extending onto style base; stigma clavate or subcapitate, 0.3 - $0.7 \mathrm{~mm}$ long, apex bilobed. Capsule 4-seeded, 9.5 $15.5 \mathrm{~mm}$ long, glabrous; seeds $3.7-4.2 \mathrm{~mm}$ long and wide.

NOTE FOR SPECIES. Barleria rigida is one of the most widespread and variable species of Barleria in Namibia and, together with $B$. irritans Nees and B. bechuanensis C. B. Clarke from South Africa, forms a difficult species complex that has recently been revised by $F$. Nyirenda and $K$. Balkwill at the University of the Witwatersrand (J herbarium). Nyirenda (2012) has proposed several new species in this group, but this revision has not yet been effectively published. Within plants previously recognised as $B$. rigida sensu lato, she splits the Namibian B. schenckii Schinz as a distinct species (although she appears to have overlooked this name and proposed the new species $B$. bracteilobis in its place - see sp. 6 below) and recognises three varieties within $B$. rigida. We largely follow this approach here, although (1) we note that the amount of geographic overlap between the varieties is rather minimal and they may be better treated as subspecies; (2) our delimitation of the varieties, and the identification of some of the specimens differs slightly from Nyirenda's (2012) work; and (3) we recognise one further, highly range-restricted variety in southern Namibia. These varieties are delimited primarily by variation in leaf, bracteole and calyx morphology including their spine systems, and in the number of flowers per inflorescence - the differences are summarised in Table 2. Whilst most specimens are fairly easy to place in one of the four varieties using the key below and comparison to named specimens, there are occasional intermediate populations, particularly where the ranges meet. Barleria schenckii could be treated as a further, extreme variety but it is considered to be sufficiently discrete that it is best treated as a vicariant species.

Dinter's (1918) records of Barleria irritans from Namibia are presumed to be misidentifications of B. rigida sensu lato, but we have not seen the relevant specimens (Dinter 233, 1989, 2122).

\section{Key to infraspecific taxa of Barleria rigida}

1. Cymes usually with 1 or 2 flowers only; outer calyx lobes green with marked white proximal portion that contrasts with the darker venation, margins with (1-) $3-9$ short spines up to $1 \mathrm{~mm}$ long; leaves with at most inconspicuous spinulose teeth less than $1 \mathrm{~mm} \operatorname{long} \ldots \ldots \ldots \ldots \ldots \ldots \ldots \ldots$ rigida At least some cymes with 3 or more flowers; outer calyx lobes variously green, pinkish or whitish, if green with a white proximal portion then without contrasting dark venation, margins with $5-20$ slender spines to $1.5-5.7$ 


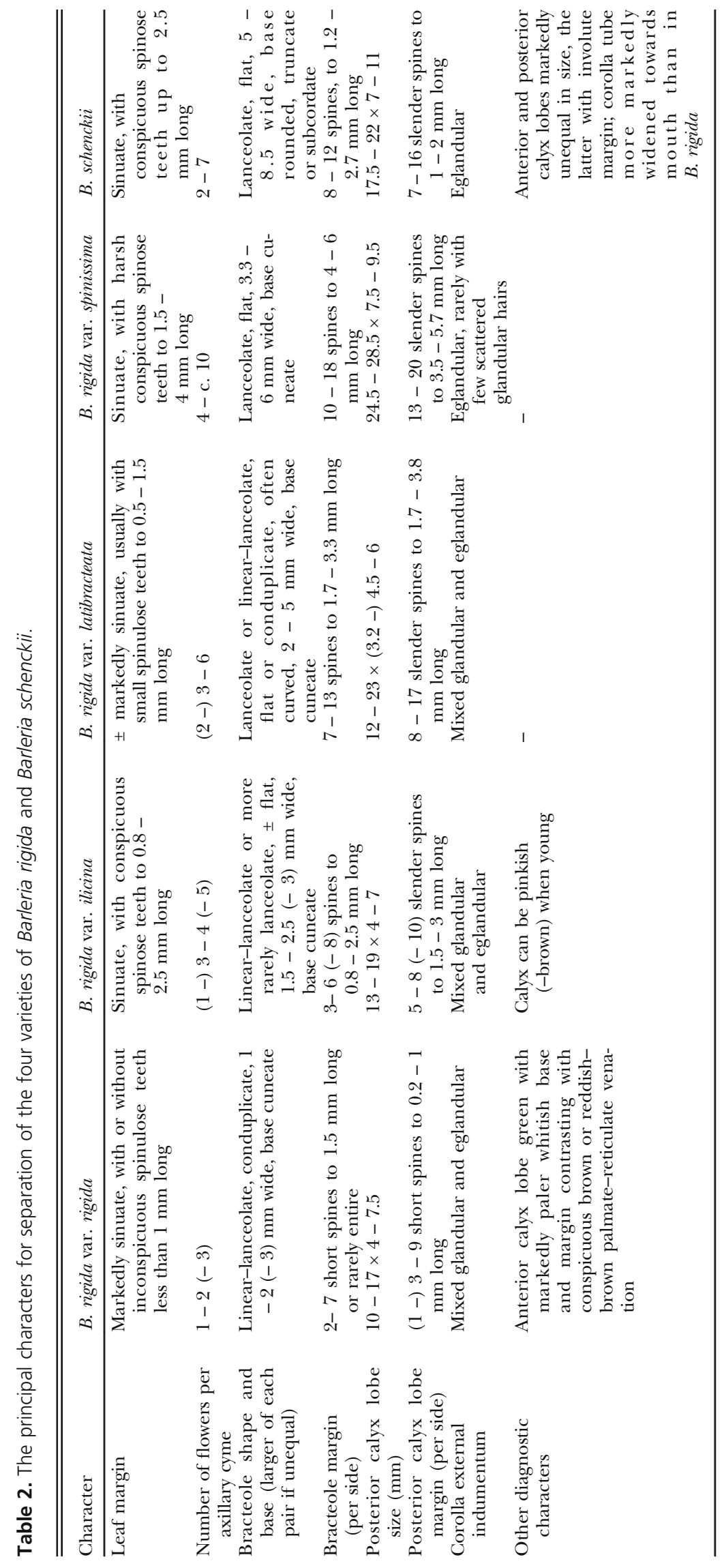


mm long; leaves with or without conspicuous spinulose teeth. . . . . . . . . . . . . . 2

2. Corolla with eglandular hairs only or at most very few glandular hairs externally; posterior calyx lobe 24.5 $28.5 \mathrm{~mm}$ long, with 13 - 20 lateral spines on each margin, the longest spines $3.5-5.7 \mathrm{~mm} \mathrm{~d}$. var. spinissima Corolla with mixed eglandular and glandular hairs externally; posterior calyx lobe $12-23 \mathrm{~mm}$ long, with $5-$ 17 lateral spines on each margin, the longest spines $1.5-3.8 \mathrm{~mm} \ldots \ldots \ldots \ldots \ldots \ldots \ldots \ldots$

3. Leaves with conspicuous marginal spines $0.8-2.5 \mathrm{~mm}$ long; bracteoles with $3-6(-8)$ spines on each margin; posterior calyx lobe with $5-8(-10)$ spines on each margin $\ldots \ldots \ldots \ldots \ldots \ldots \ldots \ldots$ b. var. ilicina Leaves with or without short spines $0.5-1.5(-2.5) \mathrm{mm}$ long; bracteoles with $7-13$ spines on each margin;

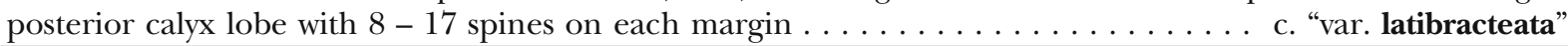

\section{5a. Barleria rigida Nees var. rigida}

Leaf margin markedly sinuate, usually with small, inconspicuous spinulose teeth typically less than $1 \mathrm{~mm}$ long, sometimes absent. Cymes $1-2(-3)$ flowered. Bracteoles linear-lanceolate, conduplicate, blade $1-2(-3) \mathrm{mm}$ wide when flat, margin with 2 - 7 short spines per side to $1.5 \mathrm{~mm}$ long or rarely entire. Outer calyx lobes green, with markedly paler whitish base and margin contrasting with conspicuous brown or reddish-brown palmate-reticulate venation; posterior lobe ovate or elliptic, 10 $17 \times 4-7.5 \mathrm{~mm}$, margin with $(1-) 3-9$ short spines $0.2-1 \mathrm{~mm}$ long or rarely to $2.5 \mathrm{~mm}$ long. Corolla with mixed glandular and eglandular hairs externally.

DISTRIBUTION. Namibia (Karas Region), South Africa (Northern Cape Prov.). Map 2.

SPECIMENS EXAMINED. NAMIBIA. Gt. Namaqualand, 20 km N of Raman's Drift, fl. \& fr. 26 Jan. 1909, Pearson 4525 (K!); Great Karasberg, Narudas Süd, bed of Keiap R., fr. 14 Jan. 1913, Pearson 7996 (K!); without precise locality, fl. $1952-1953$ [date not on specimen], Walter 2533 (M!); Warmbad Distr., c. 25 miles S of Grünau, fl. 12 April 1963, Nordenstam 2164 (M!); Karasburg, fl. \& fr. 21 June 1989, van Wyk 8573 (WIND!); Farm Genadendal 264, W slope of Karasberg, fl. 16 March 1997, Strohbach et al. 3308a (K!, WIND); Karas, Farm Grabwasser 261, near road, fl. 10 April 1999, Craven 4706a (WIND!); Farm Jerusalem 73, fl. 7 March 2008, Hasheela HHa0044 (WIND!).

HABITAT \& ECOLOGY. Barleria rigida var. rigida is recorded from dry rocky slopes, sandy plains and amongst rocks in dry riverbeds, often growing within or under thickets; it has been recorded from sandstone and from dolerite; $450-1550 \mathrm{~m}$ elevation. In Namibia, it is restricted to the Karas Dwarf Shrubland vegetation type of Mendelsohn et al. (2002), part of the Nama Karoo biome.

CONSERVATION STATUS. Although very localised in Namibia, this is the most widespread variety of Barleria rigida in the Northern Cape, where it is well represented in herbarium collections and where it can be locally common. Although some populations may have suffered from excessive browsing pressure from livestock, it is not considered to be globally threatened and is assessed as of Least Concern - LC.

NOTES. Nyirenda (2012) mapped this variety as more widespread in Namibia than recorded here but we consider this to be based on mis-identified specimens. The best example of this variety in Namibia is Pearson 4525 , this being the southeastern-most specimen. Some of the other specimens cited above tend towards var. ilicina except that they have few-flowered cymes and lack conspicuous spines on the leaf and calyx margins.

5b. Barleria rigida Nees var. ilicina (E. Mey. ex T. Anderson) Oberm. (Obermeyer 1933: 153, pro parte). $\equiv$ Barleria ilicina E. Mey. ex T. Anderson (1863: 28). Type: South Africa: "ad fluvium Garip in Africa australi”, fl. bud 19 Sept. 1830, Drège s.n. (S* [S0817420] holotype).

Leaf margin \pm sinuate, with conspicuous spinose teeth $0.8-2.5 \mathrm{~mm}$ long. Cymes $(1-) 3-4(-5)$ flowered. Bracteoles linear-lanceolate or more rarely lanceolate, \pm straight, blade \pm flat, $1.5-2.5(-3)$ $\mathrm{mm}$ wide, margin with $3-6(-8)$ spines per side, the longest of which are $0.8-2.5 \mathrm{~mm}$ long. Outer calyx lobes at first green or pinkish (-brown) with darker venation, later turning paler at least towards base and margin but then venation also pale, posterior lobe ovate, lanceolate or rarely elliptic, $13-19 \times 4-7 \mathrm{~mm}$, margin with $5-8(-10)$ slender spines per side, the longest of which are 1.5 - $3 \mathrm{~mm}$ long. Corolla with mixed glandular and eglandular hairs externally. Fig. 2E - G.

DISTRIBUTION. Namibia (Hardap and Karas Regions), South Africa (Northern Cape Prov.). Map 2.

SELECTED SPECIMENS EXAMINED. (Total of 31 Namibian specimens seen). NAMIBIA. Gt. Namaqualand, kopje $12 \mathrm{~km} \mathrm{~W}$ of Sandverhaar, fl. \& fr. 13 - 15 Feb. 1909, Pearson 4629 (K!); Kahanstal, fl. \& fr. 4 Dec. 1934, Dinter 8169 (K!); 20 miles SE of Keetmanshoop on 
road ot Narubis, fl. \& fr. 28 April 1955, de Winter 3267 (K!, M!, PRE, WIND!); Schieferberg bei Lorelei, fl. \& fr. 21 Feb. 1963, Leippert 4207 (M!); Warmbad, Farm Witpütz: WAR 258, fl. 15 May 1963, Giess et al. 6941 (M!, PRE, WIND!); Sandmodder, Keetmanshoop, fl. 5 April 1975, Müller 96 (M!, WIND!); Goodhouse Poort, fl. 22 June 1989, van Wyk 8587A (M!, PRE, WIND!); Farm Haakiesdoorn, fl. \& fr. 22 April 1997, Strohbach E Chivell 3485 (WIND!); Farm Jericho 113, road 232, fl. 8 March 2008, Hasheela HHa0058 (WIND!); 17 km W of junction of B1 and M98 (going towards Berseba), fr. 25 Aug. 2011, Tripp E Dexter 2038 (K!, RSA!, WIND!); Bukaros Volcano, W of B1 between Mariental and Keetmanshoop, fr. 26 Aug. 2011, Tripp E Dexter 2058 (K!, RSA!, WIND!); $4.8 \mathrm{~km} \mathrm{~N}$ from junction of C37 and C10, on C37, fr. 27 Aug. 2011, Tripp Ẽ Dexter 2075 (K!, RSA, WIND).

HABITAT \& ECOLOGY. Var. ilicina is recorded from dry rocky slopes, dry riverbeds and amongst dwarf shrubland on stony and sandy soils, where it grows in full sun; 690 - $1250 \mathrm{~m}$ elevation. It has a slightly broader ecological distribution than var. rigida, and is recorded from the Karas Dwarf Shrubland, Dwarf Shrub Savanna and Desert-Dwarf Shrub Transition vegetation types of Mendelsohn et al. (2002) in the Nama Karoo biome, whilst the southwestern-most populations just extend into the Succulent Steppe vegetation type of the Succulent Karoo biome (Mendelsohn et al. 2002).

CONSERVATION STATUS. This variety is widespread in southern Namibia although it only just extends into the Northern Cape. It has an EOO of $110,715 \mathrm{~km}^{2}$, well beyond the $20,000 \mathrm{~km}^{2}$ "Vulnerable" threshold for IUCN criterion B1. Furthermore, it can be locally common within its range. Therefore, whilst some populations may have suffered from excessive browsing pressure from livestock, it is not considered to be globally threatened and is assessed as of Least Concern - LC.

NOTES. Nyirenda (2012) used the consistently spiny leaf margin as the main diagnostic character for this variety, but these can also be present on other varieties; it is more the combination of this together with the bracteole and calyx characters noted in the key that allow reliable identification of this variety.

\section{5c. Barleria rigida Nees "var. latibracteata" Nyirenda} ined. (see note)

Leaf margin \pm markedly sinuate, usually with small spinulose teeth $0.5-1.5 \mathrm{~mm}$ long or rarely up to $2.5 \mathrm{~mm}$ long, sometimes absent. Cymes (2 -) 3 - 6flowered, contracted. Bracteoles (linear-) lanceolate, often curved (falcate), blade flat or conduplicate, 2 $5 \mathrm{~mm}$ wide, margin with $7-13$ slender spines per side, the longest of which are $1.7-3.3 \mathrm{~mm}$ long. Outer calyx lobes at first green or olive-green with brown venation, soon turning paler at least towards base and margin but then venation also pale, later turning pale brownscarious; posterior lobe elliptic, ovate or lanceolate, 12 - $23 \times(3.2-) 4.5-6 \mathrm{~mm}$, margin with $8-17$ slender spines per side, the longest of which are $1.7-3.8 \mathrm{~mm}$ long. Corolla with mixed glandular and eglandular hairs externally.

DISTRIBUTION. Namibia (Hardap, Karas, Khomas, Omaheke and Otjozondjupa Regions), western Botswana - see note. Map 2.

SELECTED SPECIMENS EXAMINED. (Total of 46 Namibian specimens seen). NAMIBIA. Neudam Experimental Farm, c. 20 miles E of Windhoek, fl. 17 Feb. 1955, de Winter 2359 (K!, M!, PRE, WIND!); Distr. Gibeon, Farm Haribes, fl. \& fr. 13 April 1956, Volk 12391 (M!); Avis, bei Windhoek, Vorberge der Auasberge, fl. 12 April 1960, Seydel 2283 (K!, WIND!); Rohrbeck: GIB 128, fl. 17 April 1960, Freyer 109 (WIND!); Farm Lekkerwater 32 miles E of Aranos, fl. 26 April 1960, van Vuuren E Giess 1105 (K!, M!, PRE, WIND!); Plaas Sinib, fl. \& fr. 30 April 1965, Barnard 156 (PRE, WIND!); Rehoboth Distr., road Windhoek - Walfish Bay, Farm Friedenthal 44, 20 miles from the Rehoboth border, fl. \& fr. 10 March 1968, H. E H. E. Wanntorp 168 (K!); Farm Lisbon, part of Farm Grootfontein MAL, fl. 8 April 1980, Müller 1282 (WIND!); Mariental Distr., Opstal Farm, $16 \mathrm{~km}$ from Mariental turnoff to Stampriet, fl. 11 March 1983, Germishuizen 2746 (PRE, WIND!); Mariental Distr., $\pm 6 \mathrm{~km} \mathrm{~W}$ of Weissrand along C18, fl \& fr. 24 March 1998, Strohbach \& Dauth 3738 (WIND!); Omaheke, Farm Keitsaub, fl. fr. 6 March 2002, Uiras MU474 (WIND!); Otjozondjupa, SE corner Otijku, fr. 16 May 2011, Strohbach 1060 (WIND!); Khomas, Vaalgas, E of house, fl. 15 April 2002, Strohbach BS5427 (WIND!); Hardap, Farm Duruchaus, Rehoboth, fr. 3 July 2004, Wittneben WO4-269 (WIND!).

HABITAT \& ECOLOGY. Barleria rigida var. latibracteata is recorded from dry, open situations including sandy and gravelly plains, rocky hillslopes and margins of pans and seasonal watercourses; it often grows amongst scattered dwarf shrubs; it has been recorded by several collectors from calcareous substrates; 1400 $2000 \mathrm{~m}$ elevation. It occurs primarily within the Highland Shrubland, Central Kalahari, Southern Kalahari and (for the outlier population in Otjozondjupa) Thornbush Shrubland vegetation types of Mendelsohn et al. (2002) in the Tree-and-shrub Savanna biome, but also extends into the Dwarf Shrub Savanna and Karas Dwarf Shrubland vegetation types of the Nama Karoo (Mendelsohn et al. 2002).

CONSERVATION STATUS. This is the most widespread of the infraspecific taxa of Barleria rigida with an EOO of over $170,000 \mathrm{~km}^{2}$. It can be locally common within 


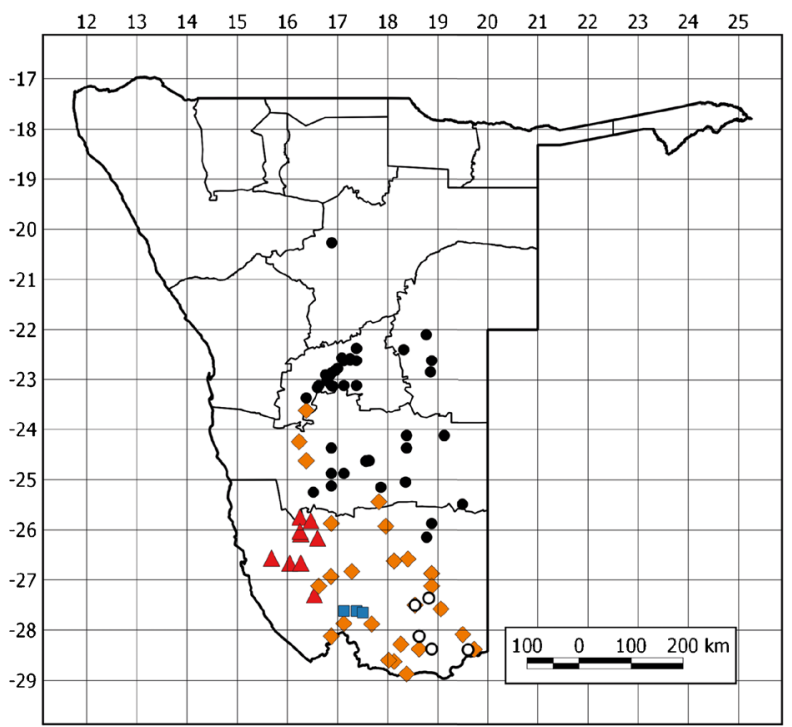

Map 2. Distribution of Barleria schenckii (red triangles), and Namibian distribution of $B$. rigida: var. rigida (white circles), var. ilicina (orange diamonds), var. latibracteata (black circles), var. spinissima (blue squares).

suitable habitat, which remains widespread. It is therefore considered to be of Least Concern - LC.

NOTES. This variety is awaiting publication by $\mathrm{F}$. Nyirenda \& K. Balkwill — it is therefore treated informally here. Nyirenda (2012) proposed the following as the type specimen: Namibia, Maltahöhe, Farm Namseb MAL 24: Grootfontein area, fl. 18 Feb. 1962, Giess, Volk E Bleissner 5189 (WIND! holotype; M!, PRE isotypes). This is not an ideal choice of specimen, as although it does conform to this variety, it has fewer spines on the calyces and bracteoles than is normal and so it tends towards var. ilicina.

The record from Otjozondjupa Region (Strohbach 1060 ) is quite isolated from the remainder of the material of this taxon but there is no doubt that it belongs here; it is strange that it has only been recorded once in this region, which has been reasonably well botanised.

Plants from western-most Botswana were placed in var. rigida by Nyirenda (2012) but they clearly match other material of var. latibracteata (see note in Darbyshire 2015) and this also conforms with the geographical distribution of the infraspecific taxa in Barleria rigida. Nyirenda (2012) also records this variety as extending to Northern Cape of South Africa, citing two specimens, van Vuuren $\mathcal{E}$ Giess 1105 (PRE) and Bayliss 5790 (MO). However, the former collection is actually from Namibia, whilst the latter is from a very vague locality — "edge of Kalahari”.

5d. Barleria rigida Nees var. spinissima I. Darbysh. var. nov. Type: Namibia, Farm Wegdraai plateau, road to canyon (run off), fl. \& fr. 14 April 2002, Helary $\mathcal{E}$ Batault 111 (holotype WIND!; isotype PRE!).

http://www.ipni.org/urn:lsid:ipni.org:names:77192292-1

Leaf margin sinuate and with harsh spinose teeth 1.5 - $4 \mathrm{~mm}$ long. Cymes 4 - c. 10-flowered, highly contracted. Bracteoles lanceolate, blade flat, 3.3 $6 \mathrm{~mm}$ wide, margin with $10-18$ slender spines per side, the longest of which are $4-6 \mathrm{~mm}$ long. Outer calyx lobes at first olive-green with brown venation but soon turning whitish in the proximal half and towards the margin but then venation also pale; posterior lobe oblong-ovate, 24.5 - $28.5 \times 7.5-$ $9.5 \mathrm{~mm}$ at maturity, margin with 13 - 20 slender spines per side of variable size, the longest of which are $3.5-5.7 \mathrm{~mm}$ long. Corolla with only eglandular hairs externally or with very few scattered glandular hairs.

RECOGNITION. This variety differs from all other varieties of Barleria rigida in having an (essentially) eglandular corolla indumentum (vs mixed glandular and eglandular), in having larger outer calyx lobes, the posterior lobe being $24.5-28.5 \times 7.5-9.5 \mathrm{~mm}$ (vs $10-23 \times 3.2-7.5 \mathrm{~mm}$ ) and in the bracteoles and outer calyx lobes having the most numerous and longest marginal spines (see Table 2).

DISTRIBUTION. Endemic to southern Namibia (Karas Region). Map 2.

ADDITIONAL SPECIMENS EXAMINED. NAMIBIA. Nuobriviertal, Richtung Apollogrotte, fl. May 1978, Wendt 52 (WIND!); Mara, fl. 30 June 1986, Craven 2516 (WIND!); Farm Mara 144, hill behind house approached from S, fr. 27 June 1987, Craven 2793 (WIND!); Farm Karios 8, W of house, fl. 24 May 1993, Craven 4106 (WIND!).

HABITAT \& ECOLOGY. Barleria rigida var. spinissima is recorded from rocky areas and stony soils in exposed arid areas including slopes; c. $700-1250 \mathrm{~m}$ elevation. It occurs in the Desert-Dwarf Shrub Transition vegetation type of Mendelsohn et al. (2002). It is a member of the Huns-Orange floristic group of Craven (2009) on the northern edge of the Gariep Centre of Endemism of van Wyk \& Smith (2001). It has a similar distribution to Barleria craveniae I. Darbysh., newly described below.

CONSERVATION STATUS. This is a very localised variety, with an EOO of approximately $1027 \mathrm{~km}^{2}$. It has been recorded as uncommon at Mara Farm and, from the few collections known, it is considered to be globally scarce. However, there are no known threats to this variety and so it is provisionally assessed as of Least Concern - LC. That said, this taxon qualifies as "Rare" (sensu Raimondo et al. 2009) in view of its small EOO coupled with the low density of individ- 
uals. If excessive livestock browsing proves to be impacting negatively on some populations of this variety, it would need to be reassessed as Endangered under IUCN criterion B.

ETYMOLOGY. The epithet "spinissima", meaning "mostspiny", refers to the numerous and conspicuous slender spines on the leaves, bracteoles and calyces of this variety.

NOTES. This is a very distinctive variety and could potentially be considered a separate species but it is certainly closely allied to var. latibracteata and var. ilicina.

6. Barleria schenckii Schinz (1890: 198); Dinter (1918: 347). Type: Tiras, fl. 1885, Schinz s.n. [no. 82 listed on $\mathrm{Z}$ sheet; Schinz 3 on K sheet] (lectotype $\mathrm{Z}^{*}$ [Z000030618], selected here; isolectotype K! [K000794969]). Additional original syntypes: Namibia, "Gross-Namaland", Aus, date unknown, Schenck 310 (?Z, not located); "Gross-Namaland", Aus, fl. 1885, Pohle s.n. (Z* [Z000079153]).

Barleria rigida sensu auctt., non Nees: Meyer (1957: 384; 1968: 16) pro parte; Welman (2003: 94) pro parte; Klopper et al. (2006: 4) pro parte; Darbyshire (2015: 49) pro parte.

Barleria rigida Nees var. ilicina (T. Anderson) Oberm.

(Obermeyer 1933: 153), pro parte, non typus.

Barleria bracteilobis Nyirenda (2012: 196), nom. illegit.

Harshly spiny shrublet, $30-60 \mathrm{~cm}$ tall, cushion-shaped to conical with many branches; stems soon turning woody then whitish or sandy-coloured, angular, with two opposite-decussate bands of short white retrorse hairs. Leaves elliptic to oblong-elliptic, $1-2.5 \times 0.5-$ $0.8 \mathrm{~cm}(\mathrm{l}: \mathrm{w}$ ratio $(1.5-) 2-3(-3.4): 1)$, base acute or often obtuse, margin white-cartilaginous, sinuate and spinose with (1 -) 3 - 12 spines per side, apex spinose, surface strigulose beneath mainly along the prominent midrib, surface elsewhere minutely puberulent but glabrescent; lateral veins c. 5 pairs, inconspicuous; petiole to $3 \mathrm{~mm}$ long. Inflorescences axillary, contracted unilateral cymes up to $3 \mathrm{~cm}$ long, each 2 - 7-flowered; bracts foliaceous; peduncle 1.5 $5.5 \mathrm{~mm}$ long; bracteoles glaucous particularly towards base and margin, tardily turning scarious, pairs unequal, the larger of each pair held erect, broadly lanceolate, $15-30 \times 5-8.5 \mathrm{~mm}$, base usually rounded, truncate or subcordate, often asymmetric, margin spinose with typically $8-12$ main spines per side, these up to $1.2-2.7 \mathrm{~mm}$ long, apex longattenuate into a harsh spine; smaller bracteole of each pair held close to inflorescence axis, linearlanceolate, surfaces minutely puberulent or glabrescent, midrib prominent. Calyx glaucousgreen, paler towards base, or sometimes purplish, can turn whitish or scarious with maturity; anterior lobe narrowly elliptic to lanceolate, $12-17 \times 5-7$ $\mathrm{mm}$, base attenuate, margin \pm revolute, spinulose with flexuose spines to $1 \mathrm{~mm}$ long, apex attenuatespinose or bispinose, surface sparsely strigose mainly on veins, sometimes also sparsely puberulous; posterior lobe ovate, $17.5-22 \times 7-11 \mathrm{~mm}$, margin usually markedly revolute and can partially envelope anterior lobe, marginal spines sometimes up to $2 \mathrm{~mm}$ long, apex long attenuate into a prominent spine, midrib prominent; lateral lobes linear-lanceolate with attenuate apex, $7-9.5 \mathrm{~mm}$ long. Corolla mauve to bright blue, 32 - $41 \mathrm{~mm}$ long, eglandular-pubescent externally; tube cylindrical, narrowly campanulate towards mouth, 22 - $25 \mathrm{~mm}$ long; limb subregular; abaxial lobe obovate, $10-14 \times 6.5-9.5 \mathrm{~mm}$, apex obtuse or shortly attenuate; lateral lobes somewhat narrower and can be obovate-elliptic, 5.5 - $8.5 \mathrm{~mm}$ wide; adaxial lobes as laterals but $5-7.5 \mathrm{~mm}$ wide. Stamens inserted 10.5 - $13 \mathrm{~mm}$ from base of corolla tube; filaments 17 - $25 \mathrm{~mm}$ long; anthers $1.8-2.3 \mathrm{~mm}$ long; lateral staminodes $2-3.5 \mathrm{~mm}$ long, pubescent at base, antherodes developed but thecae unequal, larger theca $0.5-0.6 \mathrm{~mm}$ long. Ovary with dense minute crisped white hairs at attachment point of style, with or without sparse straight hairs on surface; style glabrous; stigma linear or clavate, $0.65-0.9 \mathrm{~mm}$ long. Capsule apparently 4-seeded, $9 \mathrm{~mm}$ long (?immature), glabrous; seeds not seen.

DISTRIBUTION. Endemic to southwestern Namibia (Karas Region). Map 2.

ADDITIONAL SPECIMENS EXAMINED. NAMIBIA. Gross Namaqualand, mountains $\mathrm{S}$ of Tschauchab Station, fl. 22 Feb. 1909, Pearson 4266 (K!); Distr. Maltahohe, Farm Mount Valley 51, old fr. 19 April 1920, Lind 406 (WIND!); Distr. Lüderitz, Farm Weissenborn, fl. 5 July 1949, Kinges 2388 (M!, PRE); E-facing slopes of Sesselberge, 15 miles W of Aus, fl. 13 Aug, 1959, Giess E van Vuuren 848 (K!, M!, PRE, WIND!); Distr. Lüderitz, 48.3 miles $\mathrm{S}$ of Aus on road to Witputs, fl. 9 March 1963, de Winter Eं Hardy 7944 (K!, M!, WAG*, WIND!); Bethanien Distr., Farm Naus, fl. 21 April 1980, Owen-Smith 1317 (M!, WIND!); Namtib, fl. 27 May 2001, Theile THE89 (WIND!).

HABITAT \& ECOLOGY. Barleria schenckii is recorded from dry sandy, gravelly and stony riverbeds and flats, and from amongst boulders and cliff faces on granite and basalt outcrops; elevation is not recorded on herbarium labels, but most of this region is between (550 -) 1050 - $1650 \mathrm{~m}$ elevation. It occurs in the Southern Desert and Desert-Dwarf Shrub Transition vegetation types of Mendelsohn et al. (2002) in the transition between the Namib Desert and Nama Karoo biomes. It falls within Craven's (2009) Southern Succulent Desert floristic group.

CONSERVATION STATUS. This species is restricted to a small range in southwest Namibia, with an EOO of 
$8901 \mathrm{~km}^{2}$, and is known from few collections. Most of the known localities are found on private farms and, whilst the human population is small, livestock loads and resultant browsing pressure can be high relative to carrying capacity in this arid region. However, the impact of livestock browsing on this species is currently unknown and so Barleria schenckii is provisionally assessed as Data Deficient - DD. It is unlikely to qualify as "Rare" (sensu Raimondo et al. 2009) as its EOO is significantly greater than $500 \mathrm{~km}^{2}$, but more information is required on its population size and local abundance.

NOTES. Barleria schenckii is closely allied to B. rigida and was previously treated as a variant but it is re-elevated to species status here based on its strikingly broad, glaucous bracteoles with an abruptly narrowed base, the highly unequal outer calyx lobes with \pm revolute margins, the entirely eglandular corolla indumentum and the more campanulate corolla throat. It is most likely to be confused with forms of $B$. rigida subsp. latibracteata with broad bracteoles, which differs in the bracteoles being less abruptly narrowed at the base, in the outer calyx lobes lacking revolute margins and the pair being more equal in size, and in having a corolla indumentum of mixed eglandular and long glandular hairs. Helary $\mathcal{E}^{2}$ Batault 196 from Wegdraai in Karas (WIND!) appears somewhat intermediate between the two species - it has very broad bracteoles with an abruptly narrowed base as in B. schenckii but the corolla tube is slender and cylindrical throughout and bears some glandular hairs as in B. rigida.

The extant type material of Barleria schenckii is rather depauperate; the Schenck specimen itself has not been located and the Pohle specimen is a small branch section with old inflorescences and a single loose corolla. The $\mathrm{Z}$ sheet of the Schinz specimen is more informative and so is selected as the lectotype here. The bracteoles and calyces are somewhat narrower than seen in other material but it is otherwise a good match, including the eglandular corolla.

Nyirenda (2012) proposed this taxon as a new species, Barleria bracteilobis Nyirenda, with Theile THE89 as the type specimen. However, she appears to have overlooked the name $B$. schenckii.

7. Barleria merxmuelleri P. G. Mey. (Meyer 1957: 382), excl. Volk 2890 (= B. meeuseana); Meyer (1968: 16); Craven (1999: 152); Welman (2003: 94); Klopper et al. (2006: 4); Darbyshire et al. (2012: 765); Klaassen \& Kwembeya (2013: 130). Type: Namibia, Distr. Swakopmund, Durchfahrt zwischen Spitzkoppe und den Pontokbergen, fl. 27 March 1954, Kinges 3685 (holotype M! [M0109631]).

Harshly spiny shrublet, $10-60 \mathrm{~cm}$ tall, usually wider than tall, cushion-shaped; stems soon turning woody and then whitish, young stems white-puberulous, the hairs restricted to or concentrated in two opposite lines, retrorse or spreading, also sparsely strigulose. Leaves (oblong-) elliptic or somewhat obovate, $0.8-2.6 \times 0.3-0.9 \mathrm{~cm}$ (l:w ratio $1.75-3.1(-3.9): 1)$, base cuneate or attenuate, margin entire, apex acute, obtuse or shortly attenuate, prominently mucronate, strigulose at least on the margin and veins beneath, young leaves sometimes finely white-puberulous; lateral veins $2-4$ pairs, inconspicuous; petiole to $4.5 \mathrm{~mm}$ long. Inflorescences axillary, contracted unilateral (scorpioid) cymes up to $2.5 \mathrm{~cm}$ long but usually much shorter, each 2 - 7-flowered or flowers solitary; bracts foliaceous; bracteoles spinose, pairs unequal in length, the longer $(13.5-) 15-28 \times 0.5-0.8 \mathrm{~mm}$, triangular in cross section, margin with $(1-) 2-5(-7) \pm$ patent spines per side (1.5 -) $2.5-5 \mathrm{~mm}$ long, appearing ladder-like, sterile bracteoles persisting at lower nodes as paired axillary spines, then turning white. Calyx at first bluish-green to pale mauve with darker venation, soon turning palescarious; anterior lobe lanceolate to oblong-elliptic, 11 $13.5 \times 2-4(-5.5) \mathrm{mm}$, base cuneate, attenuate or subparallel, margin with up to 4 spines in the distal half per side or entire, apex spinose or bispinose, surface \pm sparsely strigose along the veins, rarely also with minute patent glandular hairs; posterior lobe as anterior but (oblong-) lanceolate 12.5 - $16.5 \mathrm{~mm}$ long, apex long-spinose, margin distally always with $1-4$ spines $(1.5-) 3-5 \mathrm{~mm}$ long; lateral lobes lanceolate, $6-8 \mathrm{~mm}$ long. Corolla $30-36 \mathrm{~mm}$ long, pale blue, pink or purple, eglandular-pubescent externally; tube 19.5 - $23 \mathrm{~mm}$ long, cylindrical, barely widened or narrowly campanulate towards mouth; limb subregular; abaxial lobe \pm broadly obovate (-elliptic), $9.5-$ $13 \times 8-9 \mathrm{~mm}$, apex rounded or obtuse; lateral lobes elliptic or obovate, $10-13.5 \times 7-8 \mathrm{~mm}$, apices obtuse or rounded; adaxial lobes as laterals but $6-6.5 \mathrm{~mm}$ wide, apices acute to obtuse. Stamens inserted \pm midway along corolla tube; filaments 16 - $23 \mathrm{~mm}$ long; anthers $1.9-$ $2.4 \mathrm{~mm}$ long; lateral staminodes $2-3 \mathrm{~mm}$ long, pubescent, antherodes well developed, $0.7-0.8 \mathrm{~mm}$ long. Ovary with a ring of minute crisped white hairs at attachment point of style; style glabrous; stigma linear or narrowly clavate, 0.7 $1 \mathrm{~mm}$ long. Capsule 4-seeded, 10.5 - 13 mm long, glabrous; seeds $\pm 3.5 \times 3.3 \mathrm{~mm}$. Fig. $3 \mathrm{~A} \& \mathrm{~B}$.

DISTRIBUTION. Endemic to western Namibia (Erongo, Hardap and Kunene Regions). Map 3.

SELECTED SPECIMENS EXAMINED. (Total of 28 collections seen): NAMIBIA. Farm Naudaus / Duwisib, Bez. Maltahöhe, fl. \& fr. 2 May 1956, Volk 12603 (M!, WIND!) - see note; Stadt Karibib, auf Marmorriff noerdl. der Stadt, fl. \& fr. 26 April 1969, Seydel 1947 (L!, M!, WAG*); Pontokberge bei Gr. Spitzkoppe, fr. 22 June 1961, Giess 3742 (K!, M!, PRE, WIND!); Outjo Distr., Farm Blaauwpoort: OU 520, fl. 12 April 1964, Giess E Barnard 7889 (M!, WIND!); Farm Klein Spitzkoppe: KAR 70, fl. 23 March 1965, Giess 8482 (K!, LISC!, M!, PRE, WAG*, WIND!); Distr. 

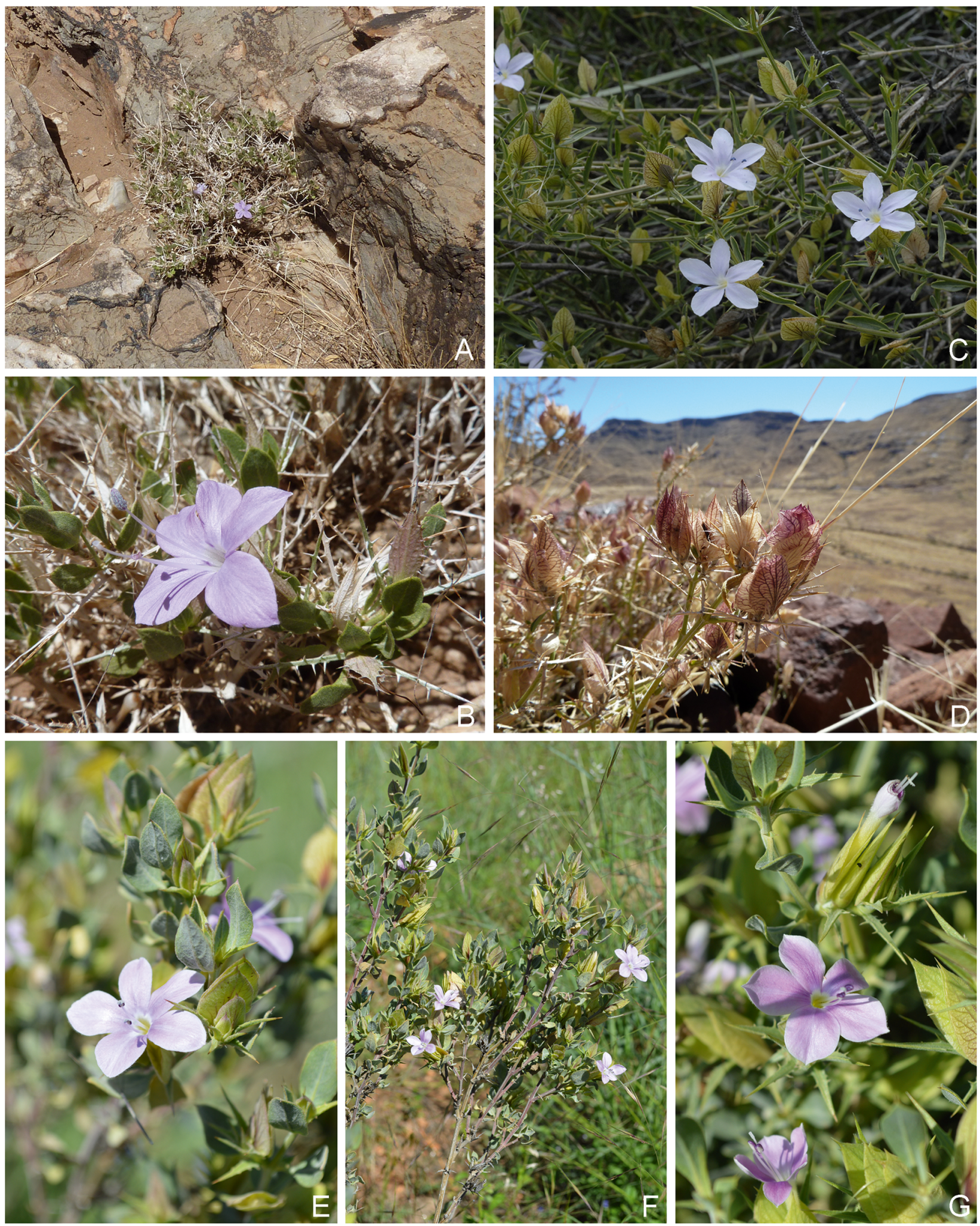

Fig. 3. A \& B Barleria merxmuelleri. A habit; B flower. C \& D B. lanceolata subsp. lanceolata. C flowering plant; D fruiting branch. E

- G B. subsp. tristis. E \& G flowering branches; F habit. A \& B Tripp 4097 (Namibia); C Namibia; D Tripp \& Dexter 2062 (Namibia); E \& F Nanyeni et al. 1050 (Namibia); G Namibia. PHotos: A, B, D E. A. TRIPP; C C. MANNHEIMER; E - G I. DARBYSHIRE. 


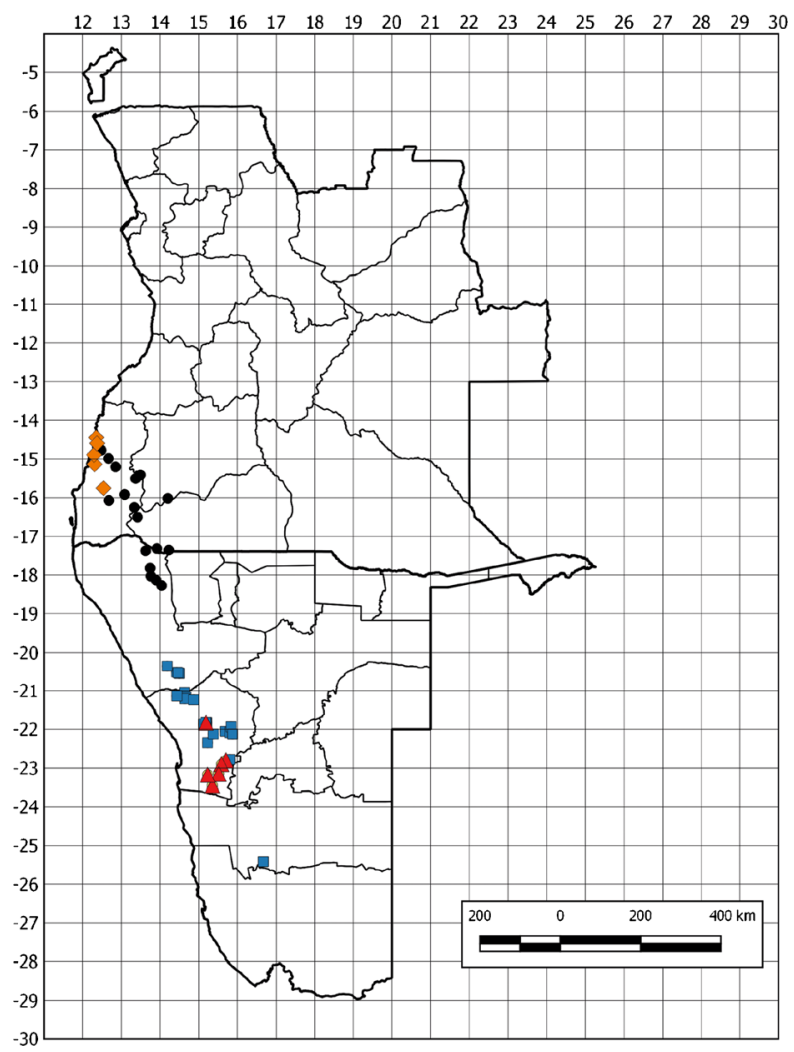

Map 3. Distribution of Barleria merxmuelleri (blue squares), $B$. merxmuelleri tending towards $B$. lanceolata (red triangles), $B$. cyanea (black circles) and $B$. deserticola (orange diamonds).

Swakopmund, S der Kleinen Spitzkoppe, fl. 23 Dec. 1967, Meyer 1022 (M!); Omaruru Distr., Uis Mine - Soris Soris, 6 miles from Uis Mine, fl. \& fr. 18 March 1968, Kers 2590 (LISC!); Groot Spitskop, W side, fl. 16 March 1971, Jensen s.n. (WIND!); 38.4 km W of Uis on the Uis-Brandberg West road, Oritsaub, fl. \& fr. 24 March 1977, Müller E Giess 372 (WIND!); Erongo, Farm Tsabichas, fl. \& fr. 7 July 2003, Schubert SS307 (WIND!); Kunene, about 7 km NE of Aba Huab camping site, N of Abu Huab R., fl. 3 March 2004, Schubert et al. SS394 (WIND!); Erongo, Usakos Distr., Valencia, fl. 31 March 2006, Strohbach E Christian BS6294 (WIND!); canyon of Huab R. Just S of C39, c. $25 \mathrm{~km}$ E of turnoff to Palmwag (junction with C39 to Torra Bay), fl. \& fr. 20 Jan. 2013, Tripp E Dexter 4097 (COLO!, K!).

HABITAT \& ECOLOGY. Barleria merxmuelleri occurs on open rocky hillslopes, outcrops, and at the base of cliffs often on granite or sandstone but also recorded from serpentine in Hardap, usually growing in dry exposed sites, on sandy or sandy-loam soils associated with drainages such as the Huab River; $400-1750 \mathrm{~m}$ elevation. It occurs in the Western Highlands, Western-central Escarpment and Inselbergs and (for the Hardap outlier) Desert-Dwarf Shrub Transition vegetation types of Mendelsohn et al. (2002). The northern part of its range falls within the Kaokoveld Centre of plant endemism (sensu van Wyk \& Smith 2001).

CONSERVATION STATUS. This species has a narrow range in west-central Namibia; it has an EOO of $38,234 \mathrm{~km}^{2}$ but if the disjunct and somewhat anomalous Hardap population is removed the EOO of its core range is only $15,365 \mathrm{~km}^{2}$. S. Schubert et al. (SS394) recorded it as common on lower mountain slopes at their site near Aba Huab. Much of its range falls within communal livestock farming areas and there is a possible threat to some populations from high browsing pressure from goats, although the impact of browsing on this species is not known. There has also been some mining activity in parts of its range, for example at Uis and near Brandberg, but this is very localised and the threat to this species appears to be minimal. It is provisionally assessed as of Least Concern - LC but with more information desirable on the impacts from livestock.

NOTES. Volk 12603, from an isolated population in Hardap region, differs from the remainder of the material in having short glandular hairs scattered on the calyx and in the posterior calyx lobe having shorter and less harsh lateral spines. In addition, the stem indumentum is finer and denser, and extends onto the inflorescence axes. More material from this region is needed to see if these differences are consistent - it is likely to warrant at least subspecies status.

This species is closely allied to Barleria lanceolata. Whilst the two are usually easily separated, there are a few specimens from Erongo region in the southern part of the core range of B. merxmuelleri (e.g. Jensen 302 from Farm Onanis; Jensen 49/1433 from Namib Park; Schmidt 1016 from Tumasberg — see Map 3) which appear intermediate. They have the dense shrubby habit and ladder-like lateral spines on the bracteoles of B. merxmuelleri but have a very finely and rather densely puberulent stem, broader, more ovate calyx lobes and \pm broader bracteoles with a narrow blade, all characters tending towards B. lanceolata subsp. tristis (see below). These are possibly a result of past hybridisation where their ranges overlap(ped). However, the two species are usually so distinct that it seems right to maintain B. merxmuelleri as a distinct species.

8. Barleria lanceolata (Schinz) Oberm. (Obermeyer 1933: 155); Meyer (1957: 381; 1968: 14); Craven (1999: 152); Welman (2003: 93); Klopper et al. (2006: 4); Darbyshire et al. (2012: 765); Mannheimer (2012: 370); Klaassen \& Kwembeya (2013: 129); Darbyshire (2015: 48). 三 Barleria acanthoides Vahl fa. lanceolata Schinz (1890: 199); Dinter (1918: 347). Type: Namibia, "Gross-Namaland", Gamochab, fl. 24 April 1885, Schinz 61 [coll., no. and date not recorded in 
protologue] (lectotype Z* [Z000029733], selected by Darbyshire 2015).

Barleria acanthoides sensu Clarke (1901: 49), non Vahl.

Spiny shrublet, $(5-) 15-100 \mathrm{~cm}$ tall; stems subangular, white-puberulous throughout or mainly restricited to two opposite lines; young stems sparsely pale-strigose and sometimes also with few minute patent glandular hairs. Leaves elliptic, narrowly oblong-elliptic, obovate or spathulate, 1.3 $4.7 \times 0.4-1.9 \mathrm{~cm}$ (l:w ratio $1.6-7: 1)$, base cuneate or attenuate, margin entire, apex acute, obtuse or sometimes rounded, sharply mucronate, strigose particularly on the margin and veins beneath, young leaves often finely whitepuberulous, sometimes with scattered minute glandular hairs; lateral veins $3-5$ pairs; petiole to $9 \mathrm{~mm}$ long. Inflorescences axillary, contracted unilateral (scorpioid) cymes $1-3 \mathrm{~cm}$ long, each $2-7$ flowered; bracts foliaceous; bracteoles linear-lanceolate, pairs unequal in length, the longer $7-23.5$ $\times 0.8-3 \mathrm{~mm}$, usually with a narrow green blade and a prominent pale midrib, apex spinose, margin with $1-11$ teeth or spines per side to $1-3.5 \mathrm{~mm}$ long or rarely subentire, sterile bracteoles sometimes present at lower nodes as paired axillary spines. Calyx at first bluish with darker venation, maturing green with or without reddish venation, before soon turning pale-scarious; anterior lobe broadly ovate, $11-17 \times(5.5-) 8-11.5(-16)$ $\mathrm{mm}$, base \pm abruptly narrowed and rounded or subcordate, margin entire or with minute bristle- tipped teeth, apex shortly attenuate to obtuse and with a short mucro, rarely notched, surface strigose along the veins, with short white hairs throughout or mainly towards the base and with or without minute patent glandular hairs; posterior lobe like anterior lobe but $14-20.5 \mathrm{~mm}$ long, apex with a more prominent mucro; lateral lobes lanceolate, 5 - $10.5 \mathrm{~mm}$ long. Corolla 25 - $42 \mathrm{~mm}$ long, lilac, pink, pale blue or more rarely white, eglandularpubescent externally with or without interspersed glandular hairs on the lateral lobes; tube 15 $25 \mathrm{~mm}$ long, cylindrical, barely widened or narrowly campanulate towards mouth; limb subregular; abaxial lobe \pm broadly obovate, $9-15.5 \times 5-13.5$ $\mathrm{mm}$, apex rounded or obtuse; lateral lobes (obovate-) elliptic or oblong-elliptic, $9.5-16.5 \times 4$ - $10 \mathrm{~mm}$, apices acute, obtuse or rounded; adaxial lobes as laterals but $3-7.5 \mathrm{~mm}$ wide. Stamens inserted $9-13.5 \mathrm{~mm}$ from base of corolla tube; filaments 13 - $27 \mathrm{~mm}$ long; anthers $1.6-2.6$ (2.9) $\mathrm{mm}$ long; lateral staminodes $1.3-4 \mathrm{~mm}$ long, pubescent towards base, antherodes well developed, $0.7-1 \mathrm{~mm}$ long. Ovary with a ring of minute crisped white hairs at attachment point of style; style glabrous; stigma clavate, $0.5-0.8 \mathrm{~mm}$ long. Capsule 4-seeded, 10 - $14 \mathrm{~mm}$ long, glabrous or with few hairs towards apex; seeds $3.5-4 \times 3.4-$ $3.7 \mathrm{~mm}$.

NOTE FOR SPECIES. Barleria lanceolata is a rather variable species; two allopatric subspecies are here recognised for the first time, with a potential third subspecies being known from only a single locality:

\section{Key to infraspecific taxa of Barleria lanceolata}

1. Plant a dwarf, compact subshrub or perennial herb with short trailing leafy stems $3-12 \mathrm{~cm}$ long; bracteoles and calyces with short glandular hairs present; leaves (oblong-) elliptic or obovate, l:w ratio $1.6-3.2: 1 \ldots \ldots \ldots \ldots \ldots$. c. subsp. A Plant usually less compact, with erect, straggling or trailing leafy stems over $15 \mathrm{~cm}$ long; if bracteoles and calyces with glandular hairs then leaves oblanceolate or spathulate to narrowly oblong-elliptic, l:w ratio (3 -)

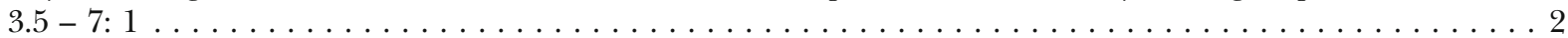

2. Leaves oblanceolate or spathulate to narrowly oblong-elliptic, l:w ratio (3-) 3.5-7: 1; outer calyx lobes \pm abruptly narrowed at base, usually rounded or subcordate, l:w ratio of anterior lobe (1.05-) 1.3 - 1.6: 1; young stems, bracteoles and/or calyces often with sparse to numerous minute patent glandular hairs ............... a. subsp. lanceolata Leaves (oblong-) elliptic or obovate, l:w ratio $2-3.7(-4.5)$ : 1; outer calyx lobes somewhat less abruptly narrowed at the base, attenuate-rounded, l:w ratio of anterior lobe typically $1.6-2(-2.3)$ : 1 ; plants lacking glandular hairs $\ldots \ldots \ldots \ldots \ldots \ldots \ldots \ldots \ldots \ldots \ldots \ldots \ldots \ldots \ldots \ldots \ldots \ldots \ldots \ldots \ldots \ldots \ldots \ldots \ldots \ldots \ldots \ldots \ldots$, b. subsp. tristis

\section{a. Barleria lanceolata (Schinz) Oberm. subsp. lanceolata}

Stems erect, straggling or trailing, usually over $15 \mathrm{~cm}$ long; white hairs on stems clearly retrorse, often confined to or most numerous in two opposite lines or bands, similar hairs present on young leaves and bracteoles but not dense; young stems, bracteoles and/or calyces often with sparse to numerous minute patent glandular hairs. Leaves oblanceo- late or spathulate to narrowly oblong-elliptic, l:w ratio (3-) $3.5-7: 1$, often bright green. Bracteoles shorter than calyx. Outer calyx lobes rather abruptly narrowed at the base, usually rounded or subcordate, l:w ratio of anterior lobe (1.05 -) 1.3 - 1.6:1, posterior lobe (1.15 -) 1.3 - 1.65:1, palmate-reticulate venation usually conspicuous, often red or red-brown and darker than the surface. Anthers $2-2.6$ (2.9) mm long. Capsule 10.5 - 12 mm long. Fig. 3C \& D. 
DISTRIBUTION. Central and southern Namibia (Hardap, Karas, Khomas and Omaheke Regions), southwestern Botswana. Map 4.

SELECTED SPECIMENS EXAMINED. (Total of 55 collections seen): NAMIBIA. 32 miles from Omitara, fl. May 1949, Liebenberg 4591 (K!, PRE, WIND!); Farm Bergland / Arovley, REH 52, fl. March 1953, Giess 1806 (WIND!); 34.4 miles W of Gobabis on road to Windhoek, fl. 24 Feb. 1955, de Winter 2503 (K!, M!, PRE, WIND!); Keetmanshoop Distr.; 35 miles SW of Narubis, fl. 7 fr. 30 April 1955, Acocks 18044 (PRE, WIND!); Gobabis Distr., Farm Held, GO 84, fl. 3 May 1963, Giess et al. 6761 (WIND!); Gobabis Region, Farm Oas, GO 284, östlich Gobabis, fl. 28 Nov. 1963, Seydel 3764 (K!, M!, SRGH!, WIND!); Genadendal, $S$ end of Great Karasberg, fl. 5 May 1976, Oliver E Steenkamp 6290a (K!, PRE); Nub West, W of Maltahöhe, fl. 9 May 1976, Oliver et al. 6507 (K!, PRE, SRGH!); Farm Rosstroppe MAL 57, fl. 9 April 1980, Müller 1304 (M!, WIND!); Karas Region, Noachabeb mts on Farm NeuNoachabeb, fl. 20 Feb. 1997, Strohbach E Kubirske 2987 (WIND!); Bethanie Distr., Farm Aruab 23, fl. April 1998, Miller MIL 1/083 (WIND!); Khomas Region, Friedrichsruh south, fl. 17 April 2002, Strohbach BS5512 (WIND!); Khomas Region, Lichtenstein South, S of main entrance road, fl. \& fr. 14 May 2002, Strohbach BS5616 (WIND!); Maltahöhe Distr., 24 km E along road D813 from junction with Maltahöhe-Helmeringhausen road (C14), fr. 1 Sept. 2005, Kolberg Eீ Tholkes HK1624 (K!, WIND!); Brukaros Volcano, W of B1 between Mariental and Keetmanshoop, fr. 26 Aug. 2011, Tripp E Dexter 2062 (K!, RSA!, WIND!); $15.2 \mathrm{~km} \mathrm{~N}$ of junction of C19 and C13, fr. 29 Aug. 2011, Tripp E Dexter 2085 (CAS!, K!,

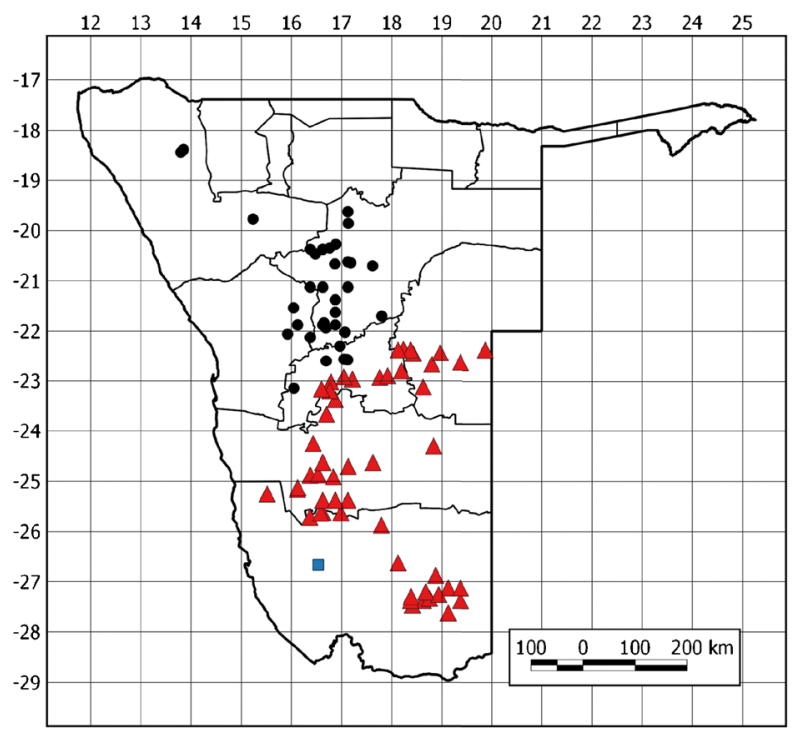

Map 4. Distribution of Barleria lanceolata: subsp. lanceolata (red triangles); subsp. tristis (black circles), subsp. A (blue square).
RSA!, WIND!). BOTSWANA. border gate between [SW Africa] Namibia and Botswana, Mamuno, fl. bud 13 Feb. 1970, R. C. Brown Mamuno 4 (SRGH!).

HABITAT \& ECOLOGY. Barleria lanceolata subsp. lanceolata occurs in open bushland, usually Acacia-dominated but also with Colophospermum mopane and Catophractes alexandri, sparse grassland, on sandy or shallow clay soils, and often on rocky hillslopes or plains or amongst boulders / rock outcrops, usually in full sun, occasionally growing along watercourses; (900 -) 1200 - 1900 m elevation. It occurs in the Karas Dwarf Shrubland, Dwarf Shrub - Southern Kalahari Transition, Southern Kalahari, Central Kalahari, Highland Shrubland, Dwarf Shrub Savanna and Desert-Dwarf Shrub Transition vegetation types of Mendelsohn et al. (2002).

CONSERVATION STATUS. This is a fairly common and widespread taxon in a variety of dry habitats in southern Namibia, with an EOO of 171,660 $\mathrm{km}^{2}$. Whilst some populations are likely to have been impacted by agricultural activities, it is unlikely to be greatly threatened. It is here assessed as of Least Concern - LC.

NOTES. When elevating this taxon from the rank of forma to species, Obermeyer (1933) recorded Dinter 2094 as the type specimen. However, whilst the collector, number and date were not recorded in the protologue, it is almost certain that Schinz's Barleria acanthoides fa. lanceolata was based on Schinz 61 which is extant at $\mathrm{Z}$ and which bears the same collecting locality as that listed in the protologue. Obermeyer's neotype is therefore superfluous.

Darbyshire et al. (2012) originally recorded this species as a Namibian endemic but a single collection from just over the border in Botswana was subsequently uncovered and included in Flora Zambesiaca (Darbyshire 2015); it is cited here for completeness.

b. Barleria lanceolata (Schinz) Oberm. subsp. tristis I. Darbysh. subsp. nov. Type: Namibia, 10.6 miles NE of Otjiwarongo on road to Otavi, fl. 18 March 1955, de Winter 2823 (holotype WIND! [WIND00031475]; isotypes K! [K001295765], M!, PRE).

http:/ /www.ipni.org/urn:lsid:ipni.org:names:60477545-2

Stems erect, straggling or trailing, usually over $15 \mathrm{~cm}$ long; white hairs on stems minute and very fine, deflexed but not clealy retrorse, dense throughout or largely confined to two opposite bands, similar hairs usually dense on the young leaves and bracteoles giving them a glaucous appearance; plants lacking glandular hairs. Leaves (oblong-) elliptic or obovate, l:w ratio $2-3.7$ (-4.5):1. Bracteoles shorter to longer than calyx. Outer calyx lobes often less abruptly narrowed at the base, attenuate-rounded, l:w ratio of anterior lobe 
1.6 - 2 (- 2.3):1, posterior lobe 1.7 - 2.3:1, palmatereticulate venation less conspicuous, often the same colour as the surface at maturity (green or turning pale-scarious) or only the main palmate veins redbrown. Anthers 1.8 - $2.2 \mathrm{~mm}$ long. Capsule 12.5 $14 \mathrm{~mm}$ long. Fig. 3E - G.

RECOGNITION. This subspecies differs from subsp. lanceolata in the leaves being (oblong-) elliptic or obovate with 1:w ratio $2-3.7(-4.5): 1$ (vs oblanceolate or spathulate to narrowly oblong-elliptic, l:w ratio (3-) $3.5-7: 1$ ); in the outer calyx lobes being proportionately narrower and less abruptly narrowed at the base, attenuate-rounded, 1:w ratio of anterior lobe typically $1.6-2(-2.3): 1$ (vs outer calyx lobes \pm abruptly narrowed at base, usually rounded or subcordate, l:w ratio of anterior lobe (1.05 -) 1.3 1.6:1); in lacking glandular hairs (vs young stems, bracteoles and/or calyces often with sparse to numerous minute patent glandular hairs) and in the young foliage having a dense minute white indumentum which gives the plant a glaucous appearance (vs these hairs less dense in subsp. lanceolata, plants not appearing glaucous).

DISTRIBUtION. Endemic to northern Namibia (Erongo, Khomas, Kunene and Otjozondjupa Regions). Map 4.

SELECTED SPECIMENS EXAMINED. (Total of 48 collections seen): NAMIBIA. Karibib Region, Farm Waldhausen, KAR 4, fr. 19 May 1953, Schwerdtfeger in H. E E. Walter 4026 (WIND!); Gamikaub R., Neuschwaben, Bez. Karibib, fl. \& fr. 31 March 1957, Seydel 1062 (K!, PRE); Karibib Region, Farm Okumitundu, fl. \& fr. 19 April 1958, Seydel 1507 (K!, LISC!, SRGH!, WAG*, WIND!); Otjiwarongo Distr., Farm Okosongomingo, fl. \& fr. 28 April 1959, Giess 2242 (M!, PRE, WIND!); along the road Karibib - Okahandja, 16 miles from Okasisi, fl. 27 March 1963, Kers 1149 (WIND!); Farm Omatako - Sicht, OK 256, fl. 20 April 1972, Woortman 83 (M!, WIND!); Otjiwarongo Horse camp, fl. 25 March 1977, P. E D. Craven 432 (WIND!); Otjiwarongo Distr., Farm Mt Etjo, 40 km from Kalkfeld on road to Okahandja, fl. 4 March 1983, Germishuizen 2543 (K!, PRE); Okahandja Distr., Thorntrees Farm, $80 \mathrm{~km}$ from Okahandja on road to Otjiwarongo, fl. 6 March 1983, Germishuizen 2594 (K!, PRE, WIND!); Damaraland, Farm Black Range 72, fl. 4 April 1990, Ward 10892 (K!, PRE, WIND!); Okahandja Distr., BIOTA Observatory, fl. 3 April 2011, Sheuyange TPS1506 (WIND!); $23 \mathrm{~km} \mathrm{~W}$ of B1/B2 junction (W of Okahandja) en route to Karibib, fl. 18 March 2010, Tripp 773 (K!, RSA!, WIND!); D2869 c. 2 km W of B1 between Otavi and Otjiwarongo, fl. 19 March 2010, Tripp 780 (K!, RSA!, WIND!); Huab R. crossing, junction of D3246 and C40 between Outjo and Kamanjab, fl. 22 March 2010, Tripp 820 (K!, RSA!, WIND!); $44 \mathrm{~km} \mathrm{~S}$ of Opuwo on C43, fl. 26 March 2010,
Tripp 854 (K!, RSA!, WIND!); along B1 NW of Windhoek c. 1 km, fr. 12 Jan. 2013, Tripp 4046 (K!, RSA!, WIND!).

HABITAT \& ECOLOGY. Subsp. tristis occupies habitats similar to those recorded for subsp. lanceolata primarily Acacia shrublands transitioning to savannas; 1100 - $1760 \mathrm{~m}$ elevation. It occurs further north in Nambia, occurring primarily in the Highland Shrubland, Thornbush Shrubland and, to a lesser extent, Western Highlands vegetation types of Mendelsohn et al. (2002).

CONSERVATION STATUS. This subspecies has an EOO of $115,246 \mathrm{~km}^{2}$. It is fairly common to locally abundant within its range and it can favour disturbed open habitats such as road verges. For example, it was recorded as very common on disturbed ground and plots around Otjiwarongo (Craven 1113). It is therefore assessed here as of Least Concern - LC.

ETYMOLOGY. The epithet "tristis", here meaning "dullcoloured", refers to the fact that the leaves and calyces in this subspecies are less brightly coloured than in the typical subspecies.

NOTES. Meyer (1957) first remarked on the possible occurrence of two geographic races in this species with the northern portion of the Khomas highlands marking the boundary between the two. He pointed to the narrower calyx and the potentially smaller flowers in the northern form. The latter character proves not to be of any value, since there is too much overlap, but the difference in calyx shape, whilst variable, is a useful character. We also note a number of other distinguishing characters above.

\section{c. Barleria lanceolata (Schinz) Oberm. subsp. A (= Kräusel 873).}

Minute shrublet or perennial herb with trailing stems 3 $12 \mathrm{~cm}$ long from a woody rootstock. White hairs on stems minute, deflexed or those in two opposite bands retrorse where most dense, similar hairs numerous on the young leaves; bracteoles and calyces with numerous minute patent glandular hairs. Leaves (oblong-) elliptic or obovate, l:w ratio 1.6 - 3.2:1. Bracteoles usually longer than or subequal in length to calyx. Outer calyx lobes \pm abruptly narrowed at the base, rounded to attenuate-rounded, l:w ratio of posterior lobe $1.5-1.7: 1$, palmate-reticulate venation conspicuous when young, darker than surface. Anthers 1.6 $2 \mathrm{~mm}$ long. Capsule (?immature) $10 \mathrm{~mm}$ long.

DISTRIBUTION. Endemic to western Namibia (Karas region). Map 4.

SPECIMENS EXAMINED. NAMIBIA. Am Hang hinter dem Wohnhaus der Farm Plateau bei Aus, fl. 21 May 1954, Kräusel 873 (M!); Farm Plateau LUS 38, ridge behind 
farmhouse, old infl. 9 Sept. 1958, de Winter $\mathcal{E}$ Giess 6246 (M!, PRE, WIND!).

HABITAT \& ECOLOGY. This taxon is recorded growing within cracks in exposed rock; c. $1500 \mathrm{~m}$ elevation on a dolomitic ridge situated in the Namib Desert, within the Desert-Dwarf Shrub Transition vegetation type of Medelsohn et al. (2002).

CONSERVATION STATUS. More information is required on the taxonomic status of this population, but if it does prove to be worthy of formal recognition, it is clearly very localised and may be globally threatened. It is currently assessed as Data Deficient - DD.

NOTES. The plants from Farm Plateau, the southwestern-most known locality for Barleria lanceolata, are notable for their small, compact stature. In terms of the combination of other characters, they are rather intermediate between the two widespread subspecies: they have proportionally broad leaves, very fine and widespread eglandular indumentum, long bracteoles and small anthers similar to subsp. tristis but have a glandular indumentum and rather broad calyces as in subsp. lanceolata. The two specimens seen to date are rather depauperate and we would prefer to see more material before making a firm decision on the status of this population.

9. Barleria cyanea S. Moore (1880: 265); Clarke (1899: 159); Hiern (1900: 816); Benoist (1950: 17); Meyer (1968: 13); Craven (1999: 152); Welman (2003: 93); Klopper et al. (2006: 4); Makholela (2008: 21); Darbyshire et al. (2012: 765); Klaassen \& Kwembeya (2013: 129). Type: Angola, Mossamedes Distr. "prope Quitibe de Cima prope Bumbo", fl. June 1860, Welwitsch 5002 (lectotype BM! [BM000931112], selected here; isolectotypes K! [K000394511], LISU! [LISU223402], P* [P02894866]).

Barleria marlothii sensu Clarke (1899: 151), pro parte quoad Johnston s.n. ex Angola, non Engl.

Shrublet with slender, weak branches $10-70 \mathrm{~cm}$ tall, longer stems often arching and sometimes becoming procumbent, or scandent then to $200 \mathrm{~cm}$ tall, sometimes with a cushion of short leafy branches at base; young stems subangular, with two opposite lines of minute white retrorse hairs, often also sparsely pale strigose; mature stems woody with pale grey bark. Leaves sometimes immature at flowering, elliptic to narrowly oblong-elliptic or somewhat oblanceolate, $1.2-3.6 \times 0.6-1 \mathrm{~cm}$ (1:w ratio $2.7-$ $5.4: 1)$, base cuneate, margin entire, apex acute or obtuse, apiculate, immature leaves sometimes more spathulate with apex rounded or retuse, palestrigose mainly on the margin and veins beneath; lateral veins $3-4$ pairs; petiole absent or to $3 \mathrm{~mm}$ long. Inflorescences axillary, flowers solitary, sessile or peduncle to $2.5 \mathrm{~mm}$ long; bracts foliaceous; bracte- oles (linear-) lanceolate or narrowly elliptic, somewhat recurved, $1.5-4.5 \times 0.5-1.2 \mathrm{~mm}$, margin entire, apex mucronate, midrib prominent abaxially. Calyx at first pale pinkish, lilac or pale green, with prominent darker palmate-reticulate venation, soon turning pale- or whitish-scarious throughout; anterior and posterior lobes subequal or the latter marginally longer, lanceolate or narrowly ovate, $7.5-15.5 \times 3-6.5 \mathrm{~mm}$; base cuneate or attenuate, margin entire or obscurely and shallowly toothed, apex acute- or subattenuate-apiculate (anterior lobe rarely notched), surfaces convex externally and with the margins becoming inrolled in fruit, external surfaces pale-strigose, sometimes also with minute white retrorse hairs particularly towards the base; lateral lobes lanceolate, 5.5 - $10 \mathrm{~mm}$ long. Corolla blue, lilac or white, with or without purple speckling in the throat and on the base of the lobes, drying blue-purple with darker venation, 19 - $32 \mathrm{~mm}$ long, eglandular-pubescent externally; tube subcylindrical, 9 - 17 mm long, somewhat narrowed centrally; limb subregular, abaxial and lateral lobes elliptic or ovate, $9-18.5 \times 6.5-11 \mathrm{~mm}$ (abaxial lobe usually the widest); adaxial lobes somewhat smaller, each lobe with apex rounded or obtuse. Stamens inserted $5-8.5 \mathrm{~mm}$ from base of corolla tube; filaments $8-$ $13 \mathrm{~mm}$ long, pubescent towards the base; anthers $2.5-3.5 \mathrm{~mm}$ long; lateral staminodes $1.2-2 \mathrm{~mm}$ long, pilose, antherodes well developed, $0.7 \mathrm{~mm}$ long. Ovary with a ring of minute crisped white hairs at attachment point of style, style sometimes also with few short spreading hairs towards base; stigma subcapitate, $0.6-0.7 \mathrm{~mm}$ long, apex unequally bilobed. Capsule 4-seeded, 12 - 16 mm long, glabrous; seeds, 4.7 $5 \times 4.3-4.5 \mathrm{~mm}$. Fig. $4 \mathrm{~A}-\mathrm{D}$.

DISTRIBUTION. Southwestern Angola (Cunene, Huíla and Namibe Provs.), northwestern Namibia (Kunene Region). Map 3.

ADDITIONAL SPECIMENS EXAMINED. ANGOLA. Chella Mts, fl. 1883, H. H. Johnston s.n. (K!); between Gambos Mission Station and Cahama, fl. \& fr. 17 May 1909, Pearson 2470 (K!); between Tampa and Ungueria, fl. 2 June 1937, Exell Ẽ Mendonça 2471 (BM!); Cainde, prox. flumen Cacuio - Bero, fl. 2 June 1937, Gossweiler 10825 (BM!, K!); Mossamedes, R. Mucungo, fl. \& fr. 12 June 1937, Carrisso Ẽ Sousa 286 (BM!, P*); Serra da Chela, Bibala, fr. 1 Aug. 1941, Gossweiler 13185 (LUBA!); [Moçademes] Namibe - Capangombe, Posto Exp. do Karakul, prox. flumen Giraul, fl. 1 June 1950, Teixeira 328-A (BM!); Moçamedes [Namibe], ao km 14 de Camucuio, estrada de Lola, fr. 7 Jan. 1956, Torre 8401 (LUBA!); Pocolo, ?nr. Paiwo, fr. 26 Dec. 1959, Stopp BO 176 (K!); andados c. $55 \mathrm{~km}$ de Moçamedes [Namibe] para Dois Irmãos, fl. 6 May 1960, Mendes 3986 (LUBA!); Huíla, Curoca, Chitado, próximo de Namalanga, fr. 17 Jan. 1962, Menezes E Henriques 72 

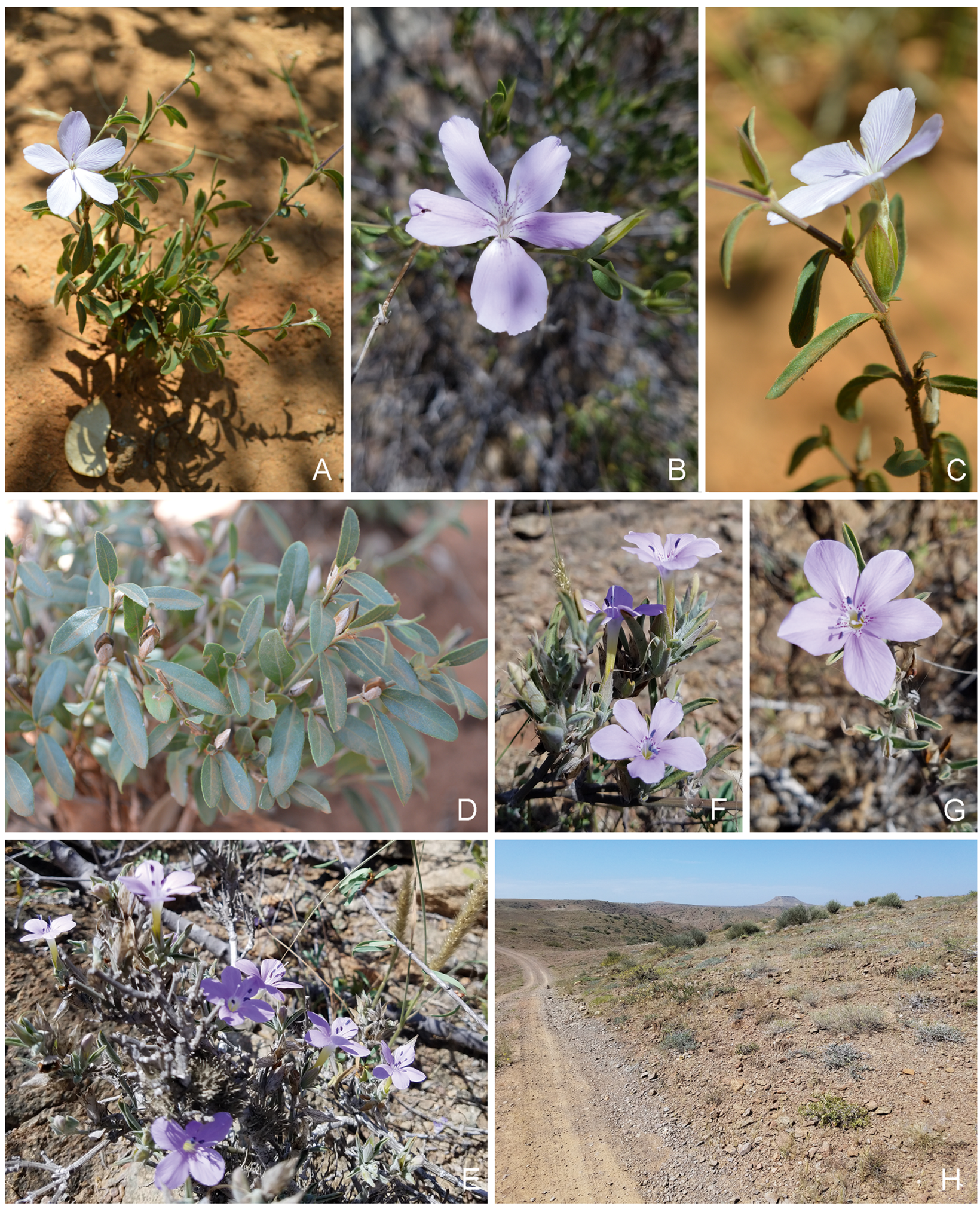

Fig. 4. A - D Barleria cyanea. A habit with flower, unspeckled form; B corolla, speckled variant; $C$ flower, lateral view; D fruiting plant. E - G B. deserticola. E habit; F \& G flowers, abaxial lobe to the left on G; H habitat for B. deserticola. A, C \& D Nyatoro et al. 27 (Namibia); B Tripp \& Dexter 6956 (Angola); E - H Tripp \& Dexter 6933 (Angola). PHOTOS: A, C \& D I. DARBYSHIRE; B, E - H E. A. TRIPP. 
(LUBA!); Cunene, Curoca, ao km 20.3 do trajecto Oncócua - Ompupa, old fr. 23 March 1973, Menezes et al. 4872 (LUBA!); $48 \mathrm{~km} \mathrm{~S}$ of Virei en route to Pediva, fl. \& fr. 16 April 2017, Tripp $\mathcal{E}$ Dexter 6956 (COLO!, K!, LUBA!); $2.8 \mathrm{~km}$ E of Ruacana border crossing into Namibia, fl. 21 April 2017, Tripp Ẽ Dexter 6970 (COLO!, K!, LUBA!). NAMIBIA. 6 miles W of Ohopoho, fr. 27 March 1957, de Winter Eं Leistner 5217 (K!, M!, PRE, WIND!); 7 Meilen südöstlich Ohopoho, fr. 3 July 1969, Meyer 1222 (M!, PRE, WIND!); 21 Meilen nördlich Ohopoho auf der Strasse nach Epembe, fl. \& fr. 4 July 1969, Meyer 1224 (M!, WIND!); Opuwo Distr., along gravel road D3709 from Omakange main road to Opuwo, fl. \& fr. 14 April 2015, Nyatoro et al. 27 (COLO!, K!, PRE!, WIND!).

HABITAT \& ECOLOGY. Barleria cyanea occurs in a variety of habitats including among open sandy flats with Colophospermum mopane and Catophractes alexandri woodland and thickets, at the bases of and among rocky areas such as koppies, and in dry bushland along river margins; $400-1400$ m elevation. It occurs in desert to semi-arid portions of the Kaokoveld Centre of plant endemism (sensu van Wyk \& Smith 2001). In Namibia, it occurs in the Western Highlands and transition to the Western Kalahari vegetation types of Mendelsohn et al. (2002).

CONSERVATION STATUS. Barleria cyanea is a range restricted species, currently known from an EOO of $31,950 \mathrm{~km}^{2}$. In Namibia it is apparently scarce, having been collected very few times despite growing in a well-botanised region. It was found to be uncommon and difficult to find in the Opuwo region in April 2015 (I. Darbyshire, pers. obs.). The herbaceous understorey of the mopane woodlands throughout this region is suffering from heavy overgrazing and degradation, particularly in a large radius around Opuwo town. In Angola, information is limited but it was recorded as extremely common at the base of koppies between Virei and Pediva (Tripp E Dexter 6948). It is known from over 10 locations (14 - 16 threat-defined locations estimated). It is currently assessed as Near Threatened - NT since it comes close to qualifying as Vulnerable under criterion B2, with a clearly defined threat to some of its locations.

10. Barleria deserticola $I$. Darbysh. E E. Tripp sp. nov. Type: Angola, Namibe Prov., c. $20.2 \mathrm{~km}$ along unnamed $4 \times 4$ track that leaves $W$ directly towards ocean from main highway between Caraculo and Bentiaba, $\mathrm{N}$ of crossing of Rio Mucungo, road to "Pupa", fl. \& old fr., 12 April 2017, Tripp E Dexter 6933 (holotype COLO!; isotypes K!, LUBA!).

http://www.ipni.org/urn:lsid:ipni.org:names:60477535-2

Barleria sp. nov.? aff. B. acanthoidisensu Moore (1880: 270).
Barleria marlothii sensu auctt., non Engl.: Clarke (1899: 151), pro parte quoad Welwitsch 5013 \& 5024; Hiern (1900: 814); Benoist (1950: 15).

Barleria damarensis sensu Makholela (2008: 21), non T. Anderson.

Dwarf shrublet with procumbent or prostrate stems, to $10-35 \mathrm{~cm}$ tall, often many-branched, the basal stems and rootstock woody; leafy stems 6-angular, puberulous with minute white retrorse hairs throughout, particularly dense in furrows along the angles; nodal line strigose. Leaves shortly petiolate, petiole to 3-8 mm long; blade narrowly oblong, oblong-elliptic or somewhat spathulate, $1-3.8 \times 0.4-0.9 \mathrm{~cm} \mathrm{(1:w}$ ratio $2.5-5.5$ ), base cuneate or attenuate, margin entire, apex acute to rounded, mucronulate, yellowishstrigose mainly on the margin and veins beneath, both surfaces white-puberulent to densely so giving the whole plant a silvery appearance, sometimes with interspersed short patent glandular hairs; lateral veins 3 - 4 pairs. Inflorescences axillary, often crowded on short lateral branches, flowers solitary or more rarely paired, peduncle $1-3.5 \mathrm{~mm}$ long, puberulent; bracts foliaceous; bracteoles linear-lanceolate or -oblanceolate, $3.5-11 \times 0.6-1.5 \mathrm{~mm}$, margin entire or with up to 3 short bristle-tipped teeth per side, apex mucronulate, can be somewhat curved, midrib prominent abaxially. Calyx at first pale green or purplegreen with green or brown venation, in fruit pale brown scarious or pink-tinged; anterior and posterior lobes subequal, (ovate-) lanceolate or anterior lobe more elliptic, $9.5-18 \times 4-6.7 \mathrm{~mm}$, base cuneate or attenuate, margin obscurely to prominently toothed with $4-8$ teeth per side up to $0.5-1.5 \mathrm{~mm}$ long and bristle-tipped, apex attenuate into a mucro or anterior lobe sometimes bifid for up to $2 \mathrm{~mm}$, external surface with prominent palmate- (or subparallel-) reticulate venation, white retrorse-puberulent throughout, with occasional yellowish strigose hairs along the main veins and with or without scattered short patent glandular hairs; lateral lobes lanceolate, 8.5 - $13 \mathrm{~mm}$ long. Corolla 25 - $36 \mathrm{~mm}$ long, pale violet-blue or purple, throat white with or without purple speckling, eglandular-pubescent externally with occasional interspersed glandular hairs on the lateral lobes; tube cylindrical, 14.5 - $23 \mathrm{~mm}$ long; limb subregular but with abaxial lobe offset by up to $2 \mathrm{~mm}$ from the other lobes; abaxial lobe obovate or obovate-elliptic, 11.5 $13.5 \times 6-8.5 \mathrm{~mm}$, apex obtuse to shallowly emarginated; lateral lobes obovate-elliptic, $10-13 \times$ $5.5-8 \mathrm{~mm}$, apices obtuse; adaxial lobes as lateral lobes but $9-12 \times 5.5-7.5 \mathrm{~mm}$. Stamens 4 perfected (see note), didynamous, either all four exserted or the shorter pair held at the mouth, longer pair with filaments c. 13.5 - $18 \mathrm{~mm}$ long, anthers $2.4-2.7 \mathrm{~mm}$ long; shorter pair with filaments 8.5 - $16 \mathrm{~mm}$ long, anthers 2 - $2.3 \mathrm{~mm}$ long; adaxial staminode variable, 
$1.5-8.3 \mathrm{~mm}$ long with antherode up to $1.2 \mathrm{~mm}$ long or antherode absent. Ovary glabrous except for apical ring of minute white crisped hairs; style glabrous; stigma linear or clavate, $0.6-0.9 \mathrm{~mm}$ long. Capsule 4seeded, 12 - $15 \mathrm{~mm}$ long, glabrous; seeds $4.5-5 \times 4-$ $4.5 \mathrm{~mm}$. Figs $4 \mathrm{E}-\mathrm{G}$ and 5 .

RECOGNITION. This species is most similar to Barleria cyanea but differs in being a compact shrublet with short trailing or procument leafy branches (vs a spindly shrublet with slender, arching or scandent leafy branches); in having a dense white-puberulent indumentum on the stems and leaves which give the plant a silvery appearance (vs stems and leaves strigose, the puberulent indumentum being restricted to two opposite bands on the stems, plants not silvery); in usually having longer bracteoles, 3.5 - $11 \mathrm{~mm}$ long (vs $1.5-4.5 \mathrm{~mm}$ long), in the outer calyx lobes usually having $4-8 \pm$ well developed marginal teeth (vs entire or at most obscurely toothed), and in having four perfected stamens (vs two perfected stamens in B. cyanea).

DISTRIBUTION. Endemic to southwestern Angola (Namibe Prov.). Map 3.

ADDITIONAL SPECIMENS EXAMINED. ANGOLA. Mossamedes Distr., "ad bassin de Serra de Montes Negros”, fr. 10 Aug. 1859, Welwitsch 5024 (BM!, K!, LISU!); "Caldeira do inferno", fr. June 1860, Welwitsch 5013 (BM!, K!, LISU!); Moçamedes [Namibe], no plateau cascalhento entre a foz dos R. Bero e Giraul, fl. \& fr. 13 June 1959, Correia 472 (LUBA!); N of Namibe, road to Baba from Lucira road, fl. \& fr. 23 Jan. 2009, Winter 7783 (PRE!); S along track that leaves towards indigenous community of Regia from main road between Namibe and Virei, fl. \& fr. 15 April 2017, Tripp Ẽ Dexter 6948 (COLO!, K!, LUBA!).

HABITAT \& ECOLOGY. Barleria deserticola is recorded from rocky desert areas, growing in sheltered crevices and edges of rock outcrops in barren terrain including on limestone and slate; recorded from near sea-level to 350 $\mathrm{m}$ elevation. It is one of the few Barleria species of southwest Africa to be found in hyper-arid areas. It is restricted to the northernmost portions of the Namib Desert at the extreme north of the Kaokoveld Centre of plant endemism (sensu van Wyk \& Smith 2001).

CONSERVATION STATUS. This species has a very small range in the vicinity of Namibe (formerly Mossamedes) in Angola, with the EOO currently recorded as only $1205 \mathrm{~km}^{2}$. Recent Acanthaceaefocussed fieldwork in this area by one of the current authors (E. A. T.) revealed two sites for this species but it was noted as uncommon and very localised at both, and at the type locality it was only found in one small area despite extensive searching. Therefore, it is considered to be globally scarce. That said, the deserts away from the coastal strip here are very sparsely populated by man and the natural habitats here are largely pristine or with only minimal disturbance. Teixeira (1968), in a review of the plant conservation priorities in Angola, noted "the Moçâmedes desert... supports a natural collection of species famous all over the world, which fortunately is not in danger" (p. 197), and this situation still appears to be largely true today. Therefore, it is quite likely that this species is not under any major threat and it is provisionally assessed as of Least Concern - LC. However, this species qualifies as "Rare" (sensu Raimondo et al. 2009) in view of its small EOO coupled with the low density of individuals.

ETYMOLOGY. The epithet "deserticola", meaning "desert-dwelling", denotes the fact that this is one of the few species of Barleria that is restricted to hyper-arid habitats in the Kaokoveld Centre of Endemism.

NOTES. This species was first collected by Welwitsch in 1859 - 1860 but his specimens, which were mainly in fruit, were wrongly placed in Barleria marlothii $(=B$. damarensis) by Clarke (1899) and Hiern (1900). Finally, after over a century and half, thanks to the recent collection of good flowering material, it is confirmed as a distinct species as Moore (1880) had suspected. It has a very different habit to $B$. damarensis and also differs in, for example, having fewer-flowered inflorescences with the bracteoles being held straight or only slightly curved (vs markedly recurved) and in having fewer glandular hairs on the young stems and calyces. Benoist's (1950) record of B. marlothii, based on Castro 117 (n.v., presumed lost on loan in Luanda during the civil war), is almost certainly referable here, as the collecting locality — Chapéu Armado a S. Nicolau is just a little further north than the Winter specimen cited. Barleria deserticola is here considered to be most closely allied to B. cyanea but differs in the characters recorded in the Recognition section. It also appears to grow in drier, desert environments than B. cyanea which prefers mopane woodland. These two species, together with $B$. damarensis for completeness, are compared in Table 3.

A striking feature of this species is the presence of four perfected, didynamous stamens. These are present in both the few flowers available on Winter 7783 and in all flowers examined on the type specimen. The adaxial portion of the androecium is also quite well developed in some flowers, with an antherode present, although it is much-reduced in others. This arrangement of the androecium is unusual for Barleria, where species typically have only two perfected stamens, but it is not unprecedented. For example, similar arrangements are seen in B. ovata Nees from South Africa and B. morrisiana E. Barnes \& C. E. C. Fisch. from India (see Balkwill and Balkwill 1997: Fig. 3A \& B). Tripp 6948, which is mainly in fruit but with one small, wilted corolla on the $\mathrm{K}$ sheet, has only two perfected stamens and the lateral androecial units are much reduced with small antherodes. This 


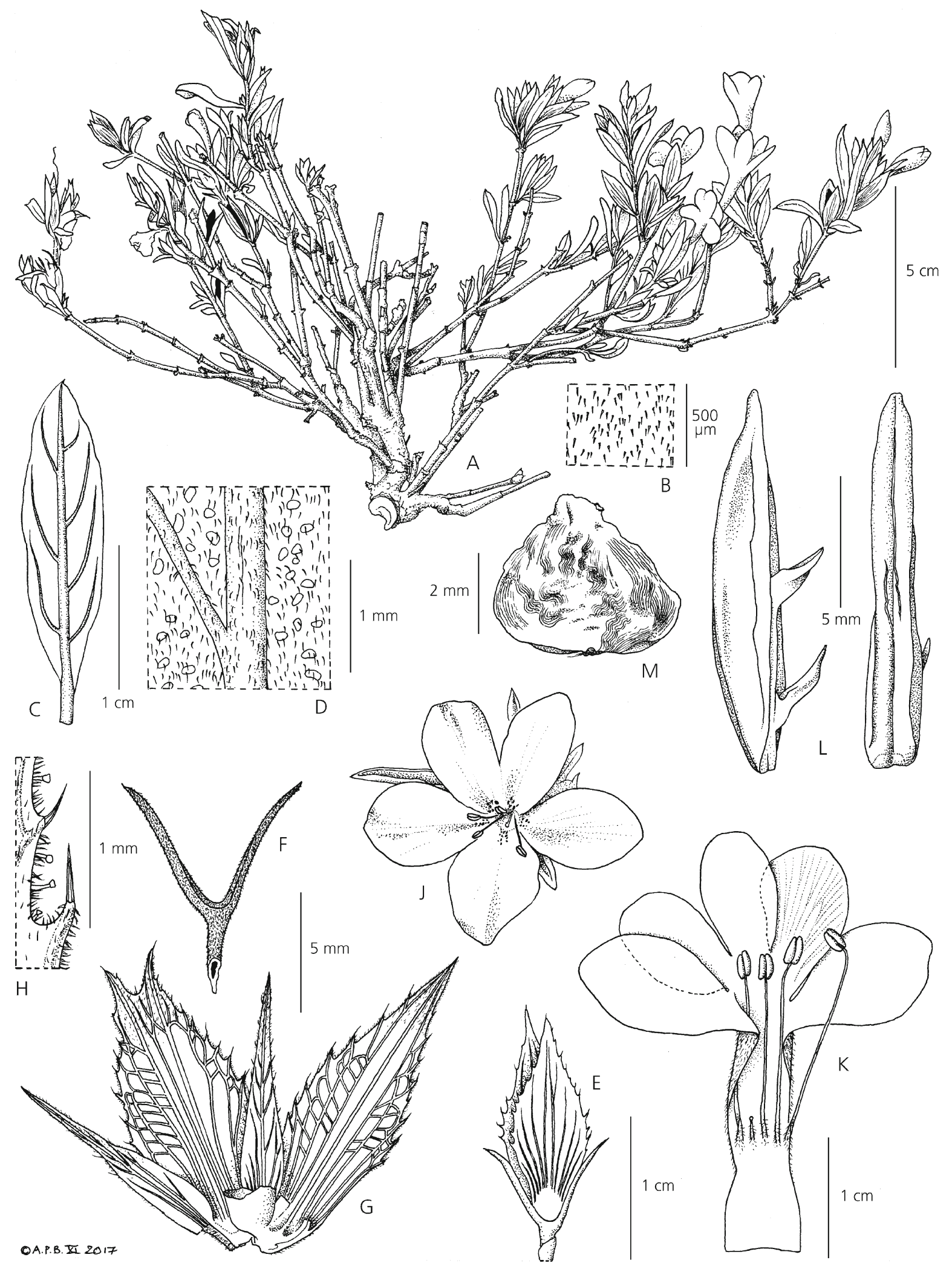

Fig. 5. Barleria deserticola. A habit; B stem indumentum; C leaf, abaxial surface; D detail of indumentum and cystoliths on abaxial leaf surface; E calyx and bracteoles in situ; F bracteoles; $\mathrm{G}$ dissected calyx, interior surface, posterior lobe to the right; $\mathrm{H}$ detail of indumentum on margin of anterior calyx lobe; J flower, speckled form; $\mathrm{K}$ dissected corolla with androecium; $\mathrm{L}$ capsule valve, face and side views; $\mathrm{M}$ seed. A - K from Tripp \& Dexter 6933 including field photos; L \& M from Welwitsch 5013. DRAWN BY ANDREW BROWN. 


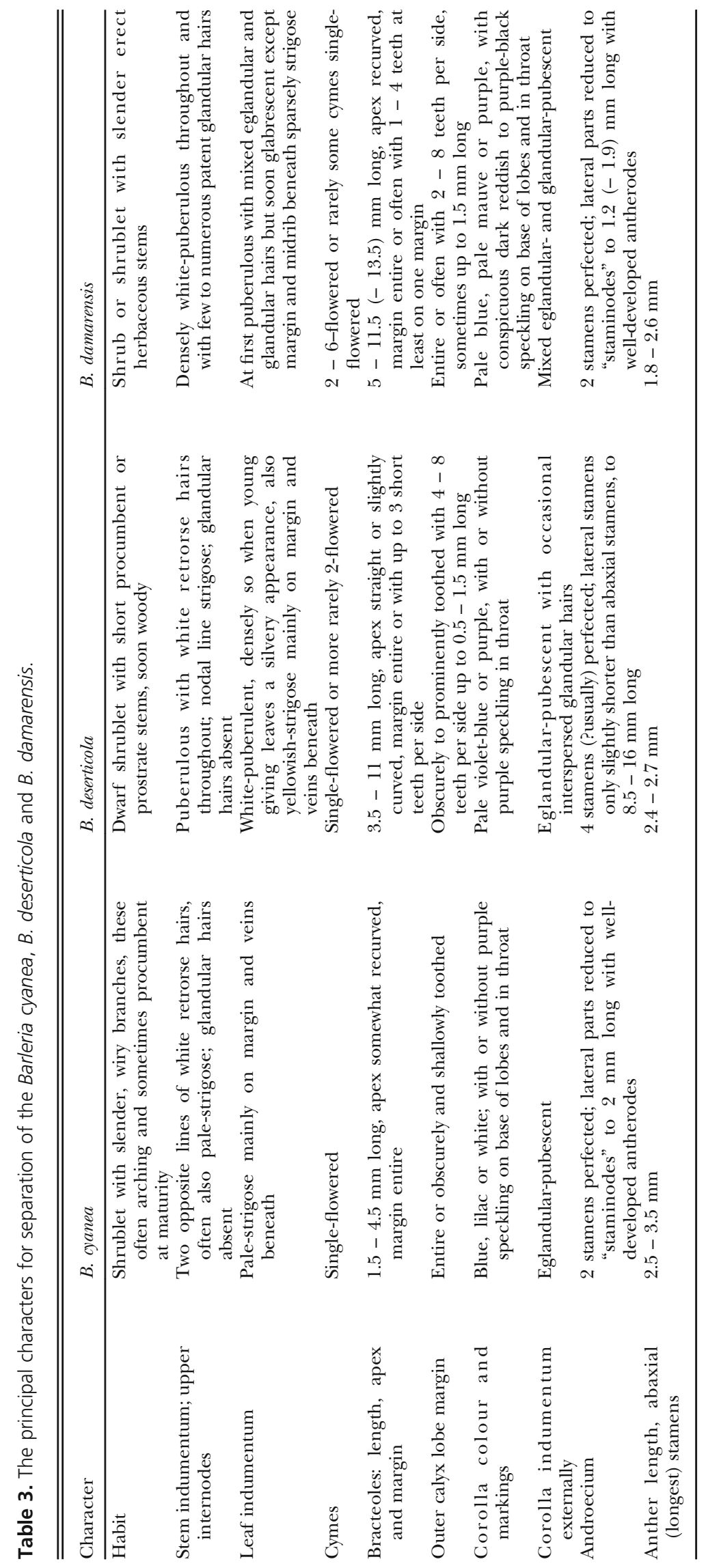


specimen also differs from the other material in having largely entire calyx lobe margins, but is otherwise a good match for $B$. deserticola. Further studies are therefore required to confirm the variability of the androecium arrangement in this species.

11. Barleria damarensis T. Anderson (1863: 29); Clarke (1899: 169); Moore (1902b: 408); Dinter (1918: 347); Obermeyer (1933: 178); Meyer (1957: 380; 1968: 13); Craven (1999: 152); Welman (2003: 93); Klopper et al. (2006: 4); Darbyshire et al. (2012: 765); Klaassen \& Kwembeya (2013: 129); Nyirenda \& Balkwill (2018: 89). Type: Namibia, "Damara Land", herb. Coll. Trin. Dublin s.n. (holotype TCD* [TCD0017903]) — see note.

Barleria marlothii Engl. (Engler 1888: 262); Clarke (1899: 151), pro parte quoad Marloth 1315 \& Schinz 11; Dinter (1918: 347); Obermeyer (1933: 155). Type: Namibia, Hereroland, Otyimbingue, fl. \& fr. May 1886, Marloth 1315 (holotype B, presumed †; isotypes BOL* [BOL150374], GRA* [GRA0002742$0])$.

Barleria jubata sensu Meyer (1968: 14), pro parte quoad Giess $\mathcal{E}$ Leippert 7588 [cited as 5588], non S. Moore.

Spiny shrub or subshrub, 20 - $110 \mathrm{~cm}$ tall, stems erect and slender; stems densely white-puberulous throughout, velutinous to the touch, and with few to very numerous short patent glandular hairs on upper internodes, nodal line strigose; mature stems woody with pale grey longitudinally fissured bark. Leaves rather stiff, elliptic to narrowly oblong-elliptic or obovate to oblanceolate, $1.7-4.4 \times 0.7-1.7 \mathrm{~cm}$ (l:w ratio $1.6-3.5: 1$ ), base cuneate or attenuate, margin entire, apex acute to rounded, mucronate, surfaces at first puberulous with mixed eglandular and glandular hairs but soon glabrescent except for sparse strigose hairs along margin and midrib beneath; lateral veins 3 - 5 (- 6) pairs; petiole to 5 (- 11) $\mathrm{mm}$ long. Inflorescences axillary, in contracted unilateral cymes $0.5-2.5 \mathrm{~cm}$ long, (1 -) $2-6$-flowered, sessile; bracts foliaceous; bracteoles green, lanceolate, \pm markedly recurved and often asymmetric, pairs unequal, the longer of each pair $5-11.5(-13.5) \times 1.8-3.3 \mathrm{~mm}$, margin entire or often with $1-4$ teeth at least along one side, apex attenuate, spinose, midrib prominent abaxially, surface densely white-puberulous and with or without short glandular hairs and/or broad sessile glands. Calyx green to pale green-brown or mauve, with \pm darker palmate-reticulate venation, only tardily turning pale-scarious; anterior lobe lanceolate, 8.5 $16 \times 2.5-4.7 \mathrm{~mm}$, margin entire or often with $2-8$ teeth per side, these sometimes elongate for up to $1.5 \mathrm{~mm}$ long, bristle-tipped, apex spinose, external surface densely (rarely more sparsely) whitepuberulous and with interspersed short glandular hairs often numerous, veins pale-strigose; posterior lobe as anterior but 9 - $18.5 \mathrm{~mm}$ long; lateral lobes lanceolate, 6 - $11 \mathrm{~mm}$ long, always with numerous glandular hairs. Corolla 26 - $37 \mathrm{~mm}$ long, pale blue, pale mauve or purple, base of lobes and mouth with dark reddish to purple-black speckling, throat with a yellow patch, tube and lateral lobes pubescent externally with mixed glandular and eglandular hairs; tube cylindrical, 14.5 - $19 \mathrm{~mm}$ long; limb in weak " $4+1$ " configuration; abaxial lobe offset by $1.5-3 \mathrm{~mm}$, broadly obovate to rounded, $10.5-14.5 \times 7-12 \mathrm{~mm}$, apex rounded or shallowly emarginated; lateral lobes obovate-elliptic, $10.5-13.5 \times 5-9 \mathrm{~mm}$, apex rounded to subacute or rarely shallowly emarginate; adaxial lobes elliptic, $10.5-13 \times 5-8.5 \mathrm{~mm}$, apex often more clearly angled. Stamens inserted $6.5-7.5 \mathrm{~mm}$ from base of corolla tube, often markedly unequal in length; filaments of longer stamen 17 - $27 \mathrm{~mm}$ long; anthers $1.8-2.6 \mathrm{~mm}$ long; lateral staminodes short, $0.7-1.2(-1.9) \mathrm{mm}$ long, pubescent, antherodes well developed, $0.8-1.1 \mathrm{~mm}$ long. Ovary with dense minute crisped white hairs at attachment point of style; stigma clavate to linear, $0.5-1 \mathrm{~mm}$ long. Capsule 4-seeded, 12.5 - $15 \mathrm{~mm}$ long, glabrous; seeds $4-5.3 \times$ $4-4.5$ mm. Fig. $6 \mathrm{~A}-\mathrm{D}$.

DISTRIBUTION. Endemic to Namibia (Erongo, Kunene, Omusati, Oshana and Otjozondjupa Regions), but possibly occurring in Angola (Cunene Prov.) - see note. Map 5.

SELECTED SPECIMENS EXAMINED. (Total of 53 collections seen): NAMIBIA. Onguati, fl. 6 April 1914, Dinter 2830 (SAM*); Kaokoveld, 4 miles $\mathrm{N}$ of Ombombo Waterhole, fl. 17 May 1957, de Winter E Leistner 5818 (K!, M!, PRE, WIND!); Otjitoko, 35 miles S of Ohopoho, fl. 3 June 1957, de Winter E Leistner 5910A (K!, M!, PRE, WIND!); Farm Otjozondu, KAR 36, am SW der Kuduberge, fl. \& fr. 6 June 1961, Giess 3474 (M!, WIND!); Kaokoveld, 3 miles S Otjitjekua, fl. 5 June 1963, Giess Eे Leippert 7340 (M!, WIND!); Kaokoveld, 20 miles S Ruacana, fl. \& fr. 14 June 1963, Giess E Leippert 7588 (PRE, WIND!); Distr. Outjo, 3 miles N Otjovasandu, Etosha Wildtuin, fl. \& fr. 13 May 1966, Joubert 165 (WIND!); Ameib NC, fl. March 1972, Jensen s.n. (WIND!); Etosha National Park [E.N.P.], Dinteri, fl. \& fr. April 1975, le Roux 1515 (WIND!); Baynesberge bei Okombambi, fr. June 1978, Rusch 38 (WIND!); Erongo region, tributary to Khan R. On Navachab Farm, fl. 29 March 1998, Curtis CUR 526 (WIND!); Erongo region, Farm Narubis Noord, fl. \& fr. 3 July 2003, Schubert SS199 (WIND!); Erongo region, Farm Achab, fl. \& fr. 8 July 2003, Schubert SS282 (WIND!); Outjo Region, Ingava, off main road near Tiervlei, fl. 14 April 2008, Crawford FC 103 (K!, WIND); Kunene region, c. $30 \mathrm{~km} \mathrm{~W}$ of C38, fl. 22 March 2010, Tripp E Dexter 819 (K!, RSA!, WIND!); on the D2743 $0.5 \mathrm{~km}$ NE of small mesa, fr. 20 Jan. 2013, 

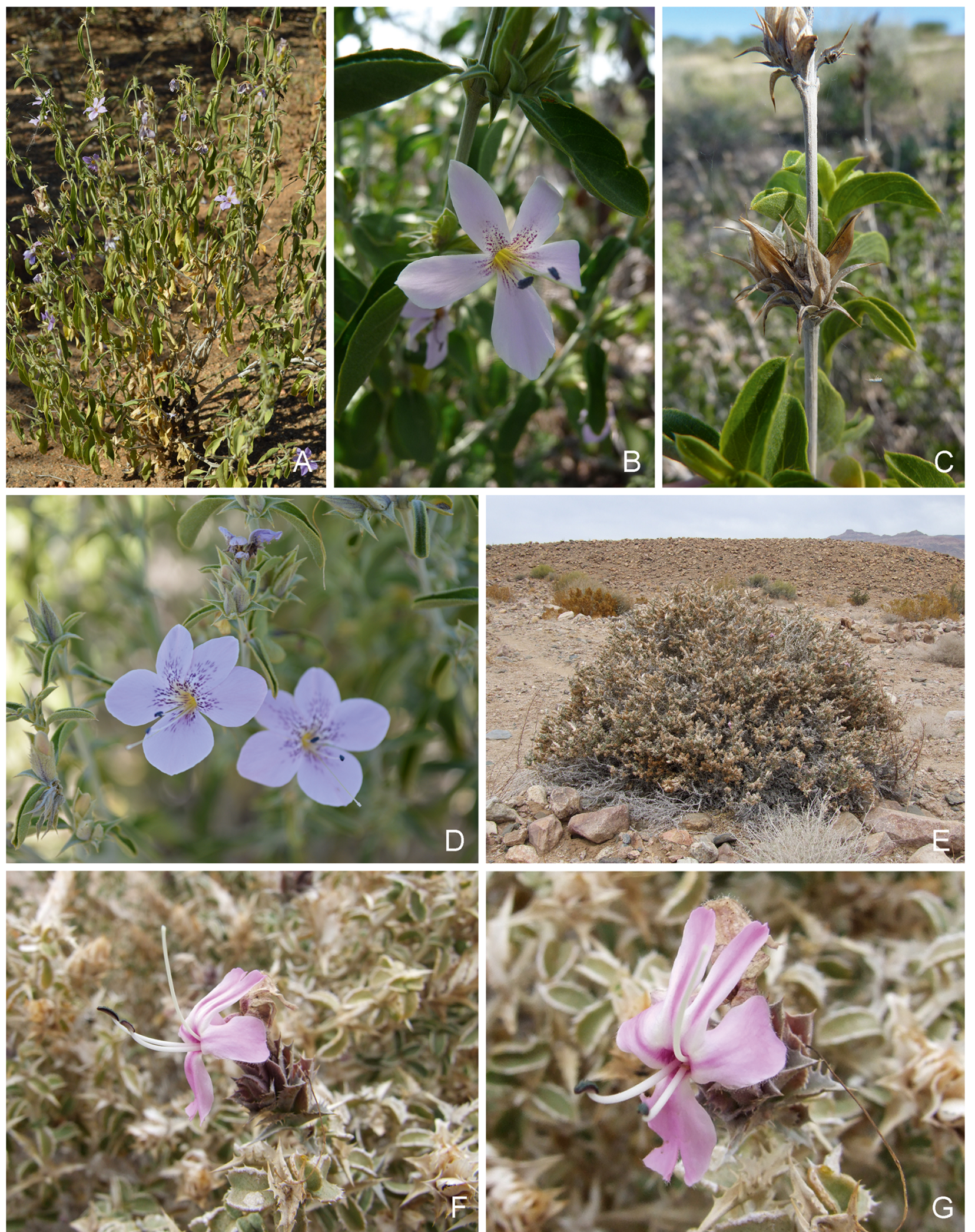

Fig. 6. A - D Barleria damarensis. A habit; B flowering branch; C fruiting branch; D flowers, variant with broader corolla lobes. E G B. craveniae. E habit; F \& G flowering branch. A \& D Klaasen et al. 2529 (Namibia); B Tripp \& Dexter 819 (Namibia); C Tripp 4102 (Namibia); E - G Kolberg \& Tholkes HK2398 (Namibia). PHOTOS: A \& D I. DARBYSHIRE; B, C E. A. TRIPP; E - G H. KOLBERG. 


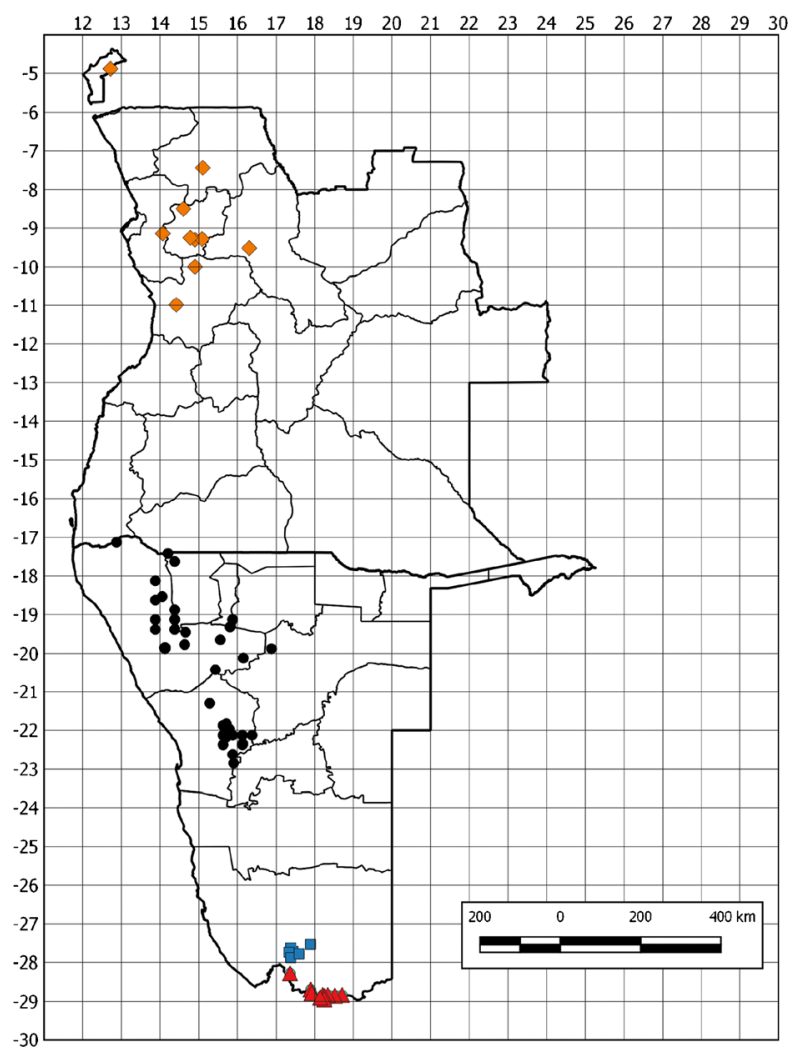

Map 5. Distribution of Barleria damarensis (black circles), $B$. papillosa (red triangles), B. craveniae (blue squares) and $B$. villosa (orange diamonds - Angolan range only).

Tripp 4102 (K!, RSA!, WIND!); along the gravel road D 3700 from Ruacana Hydro-Power Station to Omavinga Lodge, fl. 16 April 2015, Aiyambo et al. 328 (K!, WIND!).

HABITAT \& ECOLOGY. Barleria damarensis is found in a variety of dry bushland and scrub habitats, including on sandy flats, on calcrete, on rocky limestone or dolomitic hillslopes and in dry rocky riverbeds; it is also often found along road verges; c. $930-1500 \mathrm{~m}$ elevation. It occurs primarily in the Western Highlands vegetation type of Mendelsohn et al. (2002) but extends into their Western-central Escarpment and Inselbergs, Western Kalahari and Karstveld vegetation types. Its range falls partially within the Kaokoveld Centre of plant endemism (sensu van Wyk \& Smith 2001).

CONSERVATION STATUS. This species is not uncommon within its rather restricted range and is represented by numerous collections. It has an EOO of $108,707 \mathrm{~km}^{2}$, well outside of the threshold for a threat category under criterion B1. Therefore, whilst some populations are likely to have been impacted by agricultural activities, it is considered to be of Least Concern - LC.

NOTES. The combination of dense white-puberulous stem indumentum, markedly recurved green bracteoles and dark-speckled nectar guides on the corolla lobes and throat easily separates this distinctive species. The number and length of the teeth on the bracteoles and calyces are variable and the extremes (entire vs conspicuously toothed) appear rather different but the variation is clinal. Giess $\mathcal{E} 0$ Leippert 7588, which has the most conspicuously toothed bracteoles and calyces seen for this species, has been identified as Barleria jubata (and is beleived to have been cited as such by Meyer 1968 but with the number erroneously cited as 5588) but the resemblance to that species is quite superficial. Schwerdtfeger 2/199 from Grootberg is unusual in that the puberulous indumentum is less dense throughout and particularly on the calyces, giving this plant quite a different appearance, but it is otherwise a good match for B. damarensis.

This species is very likely to extend into southern Angola. It was recorded just south of the border along the Cunene River near Ruacana in 2015 (Aiyambo et al. 328; I. Darbyshire, pers. obs.). Benoist (1950) recorded Barleria marlothii from Chapéu Armado a S. Nicolau in Namibe Province based on Castro 117 but this is almost certainly a specimen of $B$. deserticola. So, for the present time, $B$. damarensis remains a Namibian endemic.

The collector of the type specimen of Barleria damarensis is uncertain; the label has a printed "Cape of Good Hope" label above which is written "Damara Land" and below which is written "E." in the same handwriting. Obermeyer (1933) indicated that the collector was Ture Johan Gustaf Een, who is known to have collected in Damaraland in the mid to late1800s. However, according to Gunn \& Codd (1981), Een's first expedition into this region was in $1866-1867$, after the publication of $B$. damarensis by Anderson (1863) and so he cannot have been the collector.

12. Barleria papillosa T. Anderson (1863: 31); Craven (1999: 152); Welman (2003: 94); Klopper et al. (2006: 4); Darbyshire et al. (2012: 765); Klaassen \& Kwembeya (2013: 130). Type: South Africa, Namaqualand, fl., without date, Wyley s.n. (holotype TCD* [TCD0013615]).

Compact spiny subshrub, forming rounded clumps 30 $120 \mathrm{~cm}$ tall and to $100-200 \mathrm{~cm}$ in diam.; young stems pale-puberulent, hairs sometimes restricted to two opposite bands, stems soon turning woody with white peeling epidermis. Leaves coriaceous, obovate or obovate-elliptic when flattened but conduplicate and curved in live state, $12-22 \times 4-11 \mathrm{~mm}$ (l:w ratio $\pm 1.5-2.1: 1$ ), base attenuate or cuneate, margin with $3-10$ harsh pale spines per side, apex obtuse or acute and with a prominent spine, surfaces puberulent including some glandular hairs; lateral veins 2 3 pairs but often indistinct; petiole $0-3 \mathrm{~mm}$ long, not well differentiated from tapered leaf base. 
Inflorescences axillary but often clustered towards stem apices, of contracted unilateral cymes $2-10 \mathrm{~cm}$ long, 4 - 20+-flowered; bracts foliaceous; primary peduncle 2.5 - $10 \mathrm{~mm}$ long or uppermost cymes sessile; bracteole pairs unequal in size, the larger held erect and adpressed to the calyx, the smaller parallel to the inflorescence axis, the larger of each pair in the distal portion of the cyme lanceolate, $10.5-19 \times 2.3-7 \mathrm{~mm}$, margin usually with $1-12$ short spines per side, apex spinose, midrib pale and prominent, surface glandular-pubescent; proximalmost pair of bracteoles usually narrower and more divergent, linear-lanceolate, the longer $15-29 \times$ $3.5-5.5 \mathrm{~mm}$, margin with harsher spines; sterile bracteoles often present at lower nodes as harsh paired or clustered patent spines, these typically linear-lanceolate, $17-38 \times 1.5-3 \mathrm{~mm}$; flowers sessile or first flower of each cyme shortly pedicellate. Calyx at first pale purple (drying purple-black or purple-brown) but turning pale-scarious at fruiting; anterior and posterior lobes often markedly unequal; anterior lobe ovate or lanceolate, $12-16.5 \times(4-)$ 5 - $9.5 \mathrm{~mm}$, base obtuse or rounded, margin denticulate or spinulose, each tooth with a terminal bristle, apex acute or obtuse with or without a short mucro or sometimes bifid and bi- or tri-mucronate, venation palmate-reticulate, external surface glandular-pubescent throughout, main veins often strigose; posterior lobe like anterior but broadly ovate, broadly ovate-elliptic or rarely more narrowly ovate, $15-20.5 \times(6-) 11-15 \mathrm{~mm}$, base obtuse to shallowly cordate, margin sometimes with more conspicuous spinulose teeth, sometimes involute towards base, apex acute to attenuate and spinetipped; lateral lobes lanceolate, 10 - $12 \mathrm{~mm}$ long. Corolla pink to purple, darkest along the midvein of each lobe, 29 - $40 \mathrm{~mm}$ long, pubescent externally, limb with mixed eglandular and glandular hairs; tube cylindrical, 14.5 - $17 \mathrm{~mm}$ long; limb in " $2+3$ " configuration but with abaxial lobe offset by 2 $4 \mathrm{~mm}$ from remaining lobes, all lobes somewhat reflexed, abaxial lobe oblanceolate or obovate, 13.5 $19.5 \times 4.5-9 \mathrm{~mm}$, apex rounded, apiculate or emarginate; lateral lobes somewhat narrower, 12.5 $17.5 \times 3.5-7 \mathrm{~mm}$; adaxial lobes subulate or narrowly spathulate, $10.5-18.5 \times 0.6-3 \mathrm{~mm}$, fused at base for $2-2.5 \mathrm{~mm}$. Stamens inserted $8.5-10 \mathrm{~mm}$ from base of corolla tube; filaments $16-24 \mathrm{~mm}$ long; anthers 3.8 - $4.5 \mathrm{~mm}$ long; lateral staminodes $0.8-1.8(-4)$ $\mathrm{mm}$ long, pubescent towards base, antherodes absent or rarely well developed, then up to $2.5 \mathrm{~mm}$ long; adaxial staminode to $1 \mathrm{~mm}$ long. Ovary with a ring of dense minute crisped white hairs at attachment point of style and extending onto style base; stigma clavate or subcapitate, $0.3-0.6 \mathrm{~mm}$ long. Capsule 4-seeded, largely enclosed within the calyx, 15.5-17 mm long including short beak, \pm notably turgid, glossy, gla- brous; seeds $5.2-5.8 \times 4.6-4.8 \mathrm{~mm}$, with creambrown to purple-brown hygroscopic hairs. Fig. 7N.

DISTRIBUTION. Namibia (Karas Region), South Africa (Northern Cape Prov.). Map 5.

ADDITIONAL SPECIMENS EXAMINED. NAMIBIA. Gr. Namaqualand, Warmbad Distr., Haib R., fl. June 1929, Marloth 13242 (PRE!); Goodhouse Poort, fl. 22 June 1989, van Wyk 8614 (PRE!, WIND!); idem, fl. \& fr. 29 Aug. 1989, van Wyk 8712 (M!, PRE!, WIND!); Farm Haakiesdoorn 197, fl. 22 April 1997, Strohbach Eं Chivell 3473 (K!, WIND!); Haib Mine (abandoned), western tributary of Haib R., N of Orange R., fr. 20 Oct. 2005, Kolberg E Tholkes HK1731 (WIND!); 2 km N of Orange R. along road D292, fl. \& fr. 22 Oct. 2005, Kolberg $\mathcal{E}^{\circ}$ Tholkes HK1742 (K!, WIND!); Farm Girtis 109, along the road to the Orange R., fl. 10 March 2008, Hasheela HHa0085 (WIND!). SOUTH AFRICA. Little Namaqualand, 5 miles $\mathrm{N}$ of Goodhouse between mountain ranges, fl. \& fr. 20 July 1937, Verdoorn E Dyer 1787 (P!, PRE!); Namaqualand Distr., about $1 \mathrm{~km}$ S of Goodhouse, fl. 5 April 2000, Balkwill et al. 11789 (K!, J); Richtersveld Mts, kloof adjacent to Orange R., below Gamkab rapid, fl. 27 April 2010, Sachse 712 (PRE!).

HABITAT \& ECOLOGY. Barleria papillosa occurs in dry open rocky habitats including dry riverbeds, gravel slopes on riverbanks and open rocky hillslopes. It has been found growing in areas of bare rocks including crevices, between boulders and amongst scree, or amongst dwarf shrubland on stony sands in association with Euclea, Schotia and Petalidium; 120 - $400 \mathrm{~m}$ elevation. It occurs in the Karas Dwarf Shrubland vegetation type of Mendelsohn et al. (2002) and is restricted to the Gariep Centre of plant endemism (sensu van Wyk \& Smith 2001).

CONSERVATION STATUS. This species has a very restricted range along the Orange (Gariep) River on the Namibia-South Africa border, with an EOO of only $2,622 \mathrm{~km}^{2}$. It was recorded as common at Farm Girtis on the Namibian side by H. Hasheela in 2008, but only occasional by B. Strohbach \& E. Chivell at Farm Haakiesdoorn. Most of the collections are from the vicinity of Goodhouse and on this stretch of the Orange River, including at Haakiesdoorn on the Namibia side, there has been extensive loss of habitat to agriculture including irrigation schemes. Attempts by W. Froneman to find this species at historic locations in Northern Cape were unsuccessful, and the sites were noted to be much disturbed (W. Froneman, pers. comm.). With $6-8$ locations estimated based on inferred threats, and with an EOO well under $20,000 \mathrm{~km}^{2}$, this species is considered to be Vulnerable - VU B1ab(iii).

NOTES. This species, and its close ally Barleria craveniae, are easily separated from other Barleria species by the unusual corolla form, with the narrow subulate or 


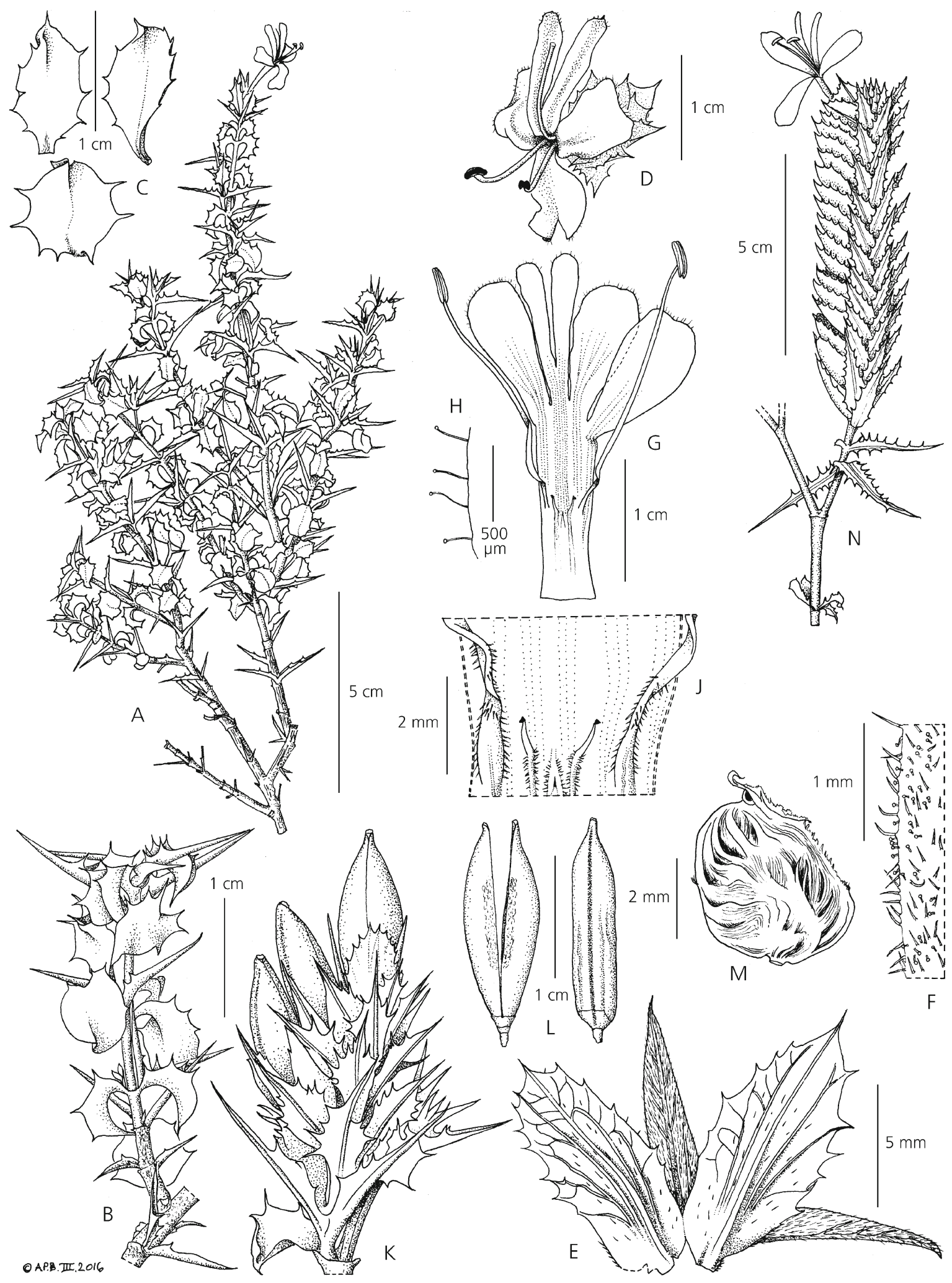

Fig. 7. A - M Barleria craveniae. A habit; B detail of one branch; C detail of leaves, adaxial surfaces; D flower in situ; $E$ dissected calyx, external surface; $\mathrm{F}$ indumentum of external surface of lateral calyx lobe; $\mathrm{G}$ dissected corolla with androecium; $\mathrm{H}$ detail of glandular haris on corolla margin; J detail of staminodes and base of fertile stamens; $\mathbf{K}$ infructescence; $\mathbf{L}$ capsule in face and lateral views; M seed. N B. papillosa, inflorescence, for comparison. A - C, E \& F Craven 3909, D from photograph by H. Kolberg, G - J Batault \& Helary 143, K - M Craven 3627, N Kolberg \& Tholkes HK1742. DRAWN BY ANDREW BROWN. 
spathulate adaxial corolla lobes being diagnostic. Barleria papillosa has been oddly overlooked in past treatments of the genus — both by Clarke (1901) in Flora Capensis and by Obermeyer (1933) and Meyer (1957, 1968) in their treatment of the southern African and Namibian members of the genus respectively.

Since this is a highly range-restricted species, all material seen has been cited including the South African specimens.

The western-most collection, Sachse 712, differs from other material in having a narrower calyx (bracketed width measurements in the description) but is otherwise a good match for typical Barleria papillosa.

13. Barleria craveniae I. Darbysh. sp. nov. Type: Namibia, Karas, Bobbejaankranz Farm 180, floodplain area of Konkiep R. near farmhouse, fl. 28 June 1991, Craven 3909 (holotype WIND!).

http://www.ipni.org/urn:lsid:ipni.org:names:77192385-1

Spiny shrub or shrublet to $60-150 \mathrm{~cm}$ tall, much branched, rounded to cushion-shaped; young stems angular, white-puberulous in two opposite bands, hairs retrorse; stems soon turning woody with white peeling epidermis. Leaves coriaceous, obovate or elliptic when flattened but blade conduplicate and curved, $8-23 \times$ $5-11 \mathrm{~mm}$ (l:w ratio $1-2: 1)$, base attenuate or cuneate, margin thickened and pale, usually with $1-6$ harsh spines per side, apex acute to rounded and spine-tipped, surfaces puberulent; lateral veins $2-3$ pairs but often indistinct; petiole to $3 \mathrm{~mm}$ long, not well differentiated from tapered leaf base. Inflorescences axillary but clustered towards stem apices, can appear terminal, of contracted unilateral cymes $1-5 \mathrm{~cm}$ long, 2 - 10-flowered; bracts foliaceous; primary peduncle to $5 \mathrm{~mm}$ long or cymes sessile; bracteoles glaucous-green or at first purplish, later turning pale sandy coloured or white, pairs slightly unequal in size, the larger held erect and adpressed to calyx, the smaller parallel to the inflorescence axis, those in the distal portion of the cyme ovate or narrowly so, $8-12 \times 2.5-5.5 \mathrm{~mm}$, margin with $5-7$ short spines per side, apex spinose, midrib prominent, surface glabrous or puberulous; proximal-most pair of bracteoles usually narrower, longer and more divergent; whitish sterile bracteoles often present at lower nodes as stiff spines, lanceolate, $11-19(-24) \times 3-5 \mathrm{~mm}$, apex harshly spinose, pairs divergent; flowers sessile. Calyx at first green to purple with darker venation, later turning sandy- to whitescarious; anterior lobe oblong-elliptic to somewhat obovate, $6.5-10 \times 3.5-4.5 \mathrm{~mm}$, base cuneate, margin spinulose-denticulate or proximal half entire, apex spinulose or shortly bifid, venation palmate-reticulate, external surface minutely glandular- and eglandularpuberulous and sometimes with antrorse eglandular hairs, or surface largely glabrous; posterior lobe like anterior but more elliptic, $9.5-11.5 \times 4-5.5 \mathrm{~mm}$, apex more markedly spine-tipped; lateral lobes linearlanceolate, 5.5 - $9 \mathrm{~mm}$ long, more densely glandularpuberulous. Corolla pink, mauve or lilac, darker along midvein of adaxial lobes, c. 24 - $31.5 \mathrm{~mm}$ long, pubescent externally with mixed eglandular and glandular hairs; tube cylindrical, 12 - $16 \mathrm{~mm}$ long; limb in " $2+3$ " configuration but with abaxial lobe offset by $2.5-3.5 \mathrm{~mm}$ from remaining lobes, all lobes somewhat reflexed, abaxial lobe obovate to oblanceolate, $11-14 \times 6-6.5 \mathrm{~mm}$, apex rounded and sometimes minutely apiculate; lateral lobes as abaxial but can be more elliptic, $10-14 \times 5-6 \mathrm{~mm}$; adaxial lobes subulate or spathulate, $11-13.5 \times 1.7-2.7 \mathrm{~mm}$, shortly fused at base, apices acute to rounded, minutely apiculate. Stamens inserted $6.8-8.5 \mathrm{~mm}$ from base of corolla tube; filaments c. $18-21 \mathrm{~mm}$ long; anthers exserted, 2.8 - $3.3 \mathrm{~mm}$ long. Ovary with sparse short retrorse hairs or glabrous except for dense minute crisped white hairs at attachment point of style and extending onto style base; stigma subcapitate to clavate, $0.3-0.5 \mathrm{~mm}$ long. Capsule 4seeded, with distal half exposed beyond the calyx, $16-$ $18 \mathrm{~mm}$ long, notably turgid, exposed portion mattblack, glabrous; seeds triangular, $5-6 \times 4-4.5 \mathrm{~mm}$. Fig. 6E - G; Fig. 7A - M.

RECOGNITION. This species resembles Barleria papillosa, but differs in the markedly smaller calyces, the posterior lobe being elliptic or somewhat obovate, $9.5-11.5 \times 4-5.5 \mathrm{~mm}$, with base cuneate (vs usually broadly ovate or ovate-elliptic, $15-20.5 \times(6-) 11-$ $15 \mathrm{~mm}$ with base obtuse to shallowly cordate in B. papillosa); in the inflorescence having short, often sparse and inconspicuous glandular hairs only (vs dense conspicuous glandular hairs throughout); and in the distal half of the capsule being exposed beyond the calyx and being matt-black (vs largely enclosed within the calyx and glossy (green-) black). It additionally differs in having smaller and more ovate fertile bracteoles, 8 - $12 \mathrm{~mm}$ long (vs lanceolate, 10.5 $19 \mathrm{~mm}$ long), in having considerably shorter axillary "spines" (sterile bracteoles) at lower nodes, 11 - 19 (24) $\mathrm{mm}$ long, which are less clearly differentiated from the fertile bracteoles (in B. papillosa these are harsh linear-lanceolate spines 17 - $38 \mathrm{~mm}$ long and clearly different to the fertile bracteoles) and in having smaller anthers, $2.8-3.3 \mathrm{~mm}$ long (vs $3.8-4.5 \mathrm{~mm}$ in B. papillosa).

DISTRIBUTION. Endemic to southern Namibia (Karas Region). Map 5.

ADDITIONAL SPECIMENS EXAMINED. NAMIBIA. Bethanien Distr., Farm Mara No. 114, st. 11 Feb. 1979, Owen-Smith 1226 (WIND!); Mara, $\mathrm{N}$ of house, tributary of 
Konkiep, fl. 6 July 1986, Craven 2563 (WIND!); Wegdraai, Kochas R., fl. 24 April 2002, Batault E Helary 143 (WIND!); Mara Farm 114, Hunsberg, Cloete's Kloof, fr. 26 Sept. 1989, Craven 3536 (WIND!); Mara Farm 144, Diaz kloof, fr. 1 Oct. 1989, Craven 3627b (WIND!); Bethanie Distr., Farm Mara, tributary to Konkiep c. $3 \mathrm{~km} \mathrm{~N}$ of homestead, fl. 17 Oct. 2007, Kolberg E Tholkes HK2398 (WIND!); Fish R. Canyon, Kooigoed Highlands, fl. 12 June 2010, T. Rebelo (photo. record on ispot: http://www.ispotnature.org/ species-dictionaries/sanbi/Barleria\%20papillosa).

HABITAT \& ECOLOGY. Barleria craveniae grows in dry riverbeds and washes, either on sandy soils or amongst rocks, growing in full sun amongst open dry shrubland; c. $300-850 \mathrm{~m}$ elevation. It is recorded mainly from the Desert-Dwarf Shrub Transition vegetation type of Mendelsohn et al. (2002). It is a member of the ancient Huns-Orange floristic group of Craven (2009) and is a component of the Gariep Centre of plant endemism (sensu van Wyk \& Smith 2001).

CONSERVATION STATUS. Barleria craveniae has a highly restricted range in southern Namibia, with an EOO of only $895 \mathrm{~km}^{2}$. Only a few plants were recorded at Wegdraai by N. Batault E S. Helary (143). However, $P$. Craven recorded it as locally common to very numerous at Mara Farm (her 2563 and 3627). The arid region in which this species occurs is sparsely populated by man, and threats from human activity appear to be minimal, although over-browsing by domestic goats may exsert some pressure. Therefore, despite its very small range, this species is currently assessed as of Least Concern - LC. However, this species qualifies as "Rare" (sensu Raimondo et al. 2009) in view of its small EOO coupled with the low density of individuals.

ETYMOLOGY. This species is named for Patricia Craven, in honour of her valuable contribution to our understanding of the flora and phytogeography of Namibia. This species is closely associated with Pat since she collected the type collection and her family own Mara Farm, one of the few known localities for this rare species.

NOTES. This newly described species is clearly closely allied to Barleria papillosa; the two species share the unusual corolla morphology with subulate or narrowly spathulate adaxial lobes, and have similar vegetative parts. However, the inflorescences look very different due to the differing calyx, bracteoles and indumentum, hence they are considered to be allopatric vicariant species, both confined to the Gariep Centre of plant endemism of the Orange (Gariep) River and its tributaries. Barleria craveniae occurs in the small area of southwestern Namibia that receives both summer and winter rainfall, although annual rainfall is very low in this area (Mendelsohn et al. 2002).
14. Barleria lichtensteiniana Nees (1847: 235); Masters (1870: 73); Clarke (1901: 51); Dinter (1918: 347); Marloth (1932: 172, pl. 45B); Obermeyer (1933: 158); Meyer (1957: 382; 1968: 14); Craven (1999: 152); Welman (2003: 94); Klopper et al. (2006: 4); Darbyshire et al. (2012: 765); Klaassen \& Kwembeya (2013: 129). Type: South Africa, plains at the foot of the Asbestos Mts, between Kloof village and Witte Water, Griqualand West, fl. 17 Feb. 1812 [locality and date not cited in protologue or listed on lectotype recorded on K sheet only], Burchell 2068 (lectotype GDC* [G00450133], selected here; isolectotypes GZU* [GZU000271492], K! [K001295766], PRE). Additional original syntypes: South Africa, "ad Grootriviers poort in prom. B. Sp.", fr., date unknown, Lichtenstein s.n. (syntype B†; isosyntype GZU* [GZU000250927]); Griqualand West, Hay Div., Asbestos Mts, at Kloof Village, fr. 15 Sept. 1811 [locality and date not cited in protologue - listed on K sheet only], Burchell 1652 (syntype G-DC* [G00450134]; isosyntype K! [K001295767]).

Spiny perennial herb or subshrub, with prostrate, procumbent, decumbent or scrambling branches $40-100 \mathrm{~cm}$ long from a woody base; young stems with dense short white (sub)appressed retrorse hairs sometimes most dense in two opposite furrows; mature stems glabrescent, woody with peeling sandy or whitish bark. Leaves sometimes immature at flowering, blade ovate, lanceolate or narrowly elliptic, $1.8-4.2 \times 0.7-1.4 \mathrm{~cm}$ (1:w ratio $2-3.8: 1$ ), base cuneate or attenuate, margin entire, apex acute or rarely obtuse, tip mucronate or spinose, surfaces with dense appressed short white hairs throughout when young giving the leaves a greygreen appearance, less dense at maturity, often also with scattered broad sessile glands; lateral veins indistinct; petiole $(0-) 2-9 \mathrm{~mm}$ long. Inflorescences axillary, contracted strobilate unilateral cymes 3 $8.5 \mathrm{~cm}$ long in the upper leaf axils, 5 - 20+-flowered; axis somewhat inrolled at fruiting; bracteoles imbricate and enclosing the base of the calyces, green or pink-tinged, ovate or lanceolate, pairs unequal, the larger $17-29 \times 7-14.5 \mathrm{~mm}$, margin with prominent flexuose spines $2.5-7 \mathrm{~mm}$ long, apex spinose, surface tripliveined, main veins and margin hispid, surface with short appressed or somewhat spreading hairs; paired reduced sterile bracteoles sometimes present at lower nodes. Calyx at first pale green to blue-green or mauve with darker reticulate venation, later turning pale-scarious, accrescent; anterior lobe broadly ovate, $17.5-20 \times 15-18 \mathrm{~mm}$ in flower, up to $25 \times 23 \mathrm{~mm}$ in fruit, base shallowly cordate, margin entire or often with few flexuose spines towards base and minute teeth formed by swollen hair bases elsewhere, apex obtuse, acute or rounded, mucronulate, surface rather hispidly hairy especially on the veins and margin and with \pm dense short spreading hairs throughout; 
posterior lobe like anterior lobe but $21.5-30 \times 16-$ $20 \mathrm{~mm}$ in flower, up to $32 \times 24 \mathrm{~mm}$ in fruit, margin with $7-14$ prominent flexuose spines of varying length, up to $2.5-7.5 \mathrm{~mm}$ long, the longest spines often submarginal, apex attenuate into a prominent spine; lateral lobes lanceolate, 7 - $10 \mathrm{~mm}$ long, with some short glandular hairs. Corolla of chasmogamous flowers 33 - $40 \mathrm{~mm}$ long, pink, lilac-blue or mauvepink, glandular- and eglandular-pubescent externally; tube 22.5 - $27 \mathrm{~mm}$ long, cylindrical but somewhat expanded towards mouth; limb subregular but with sinus between adaxial pair at a wider angle than other sinuses; abaxial lobe obovate or obovate-elliptic, 11 $15.5 \times 5.5-10 \mathrm{~mm}$, apex rounded or shallowly emarginate, lateral lobes (obovate-) elliptic, 11.5 $16 \times 5.5-11 \mathrm{~mm}$, apices rounded or obtuse, adaxial lobes elliptic to ovate-elliptic, $11.5-15.5 \times 5.5-9.5$ $\mathrm{mm}$, apices rounded to acute; cleistogamous flowers frequent, appearing as buds c. $4.5 \mathrm{~mm}$ long with the style forming a u-shaped loop beyond the closed corolla lobes, stigma held below anthers. Stamens of chasmogamous flowers inserted 12.5 - $14 \mathrm{~mm}$ from base of corolla tube; filaments 21 - $28 \mathrm{~mm}$ long; anthers exserted, 2.6 - $3.6 \mathrm{~mm}$ long; lateral staminodes $2.5-4.5 \mathrm{~mm}$ long, pubescent in proximal portion, antherodes poorly developed, $0.35-0.6 \mathrm{~mm}$ long. Ovary with ring of dense minute crisped white hairs at attachment point of style and extending onto style base; stigma clavate, $0.6-0.9 \mathrm{~mm}$ long. Capsule 4 seeded, $14-17 \mathrm{~mm}$ long, glabrous; seeds $5.5-7 \times$ $5.5-6.5 \mathrm{~mm}$. Fig. $8 \mathrm{~A}-\mathrm{C}$.

DISTRIBUTION. Namibia (Karas Region) and South Africa (Northern Cape Prov.). Map 6.

SELECTED SPECIMENS EXAMINED. (Total of 17 Namibian collections seen): NAMIBIA. Klein Karas, fr. 1 Aug. 1923, Dinter 4750 (K!, L*, PRE, Z*); Great Karas Mts, 30 miles $\mathrm{S}$ of Narubis on road to Grünau, fl. \& fr. 29 April 1955, de Winter 3295 (K!, M!, PRE, WIND!); Farm Udabis: WAR 77, fl. \& fr. 19 May 1963, Giess et al. 7084 (M!, PRE, WIND!); 3 km S Aroab, fl. 29 May 1970, Giess E् Wolf 10942 (WIND!); Farm Keimas: WAR 99, fl. \& fr. 24 May 1972, Giess E Müller 12186 (M!, PRE, WIND!); Karas Region, 4 km from Grünau on Holoog - Seeheim road, fr. 28 Oct. 1987, Kolberg $\mathcal{E}^{\circ}$ Maggs 287 (WAG*, WIND!); Karasberge, Graberberg, Farm Rishon, near Post Office tower, fr. 23 June 1989, van Wyk 8689 (PRE, WIND!); Karas Region, Farm Witkop, on edge of Blydeverwagt Plato along D202, fl. 18 April 1997, Strohbach $\mathcal{F}^{2}$ Chivell 3390 (K!, WIND!); Karasburg Distr., Hamab R., along the road to Ariamsvlei, fl. 6 March 2008, Hasheela Hha0029 (WIND!); Karas Region, Farm Jericho 113, fl. 8 March 2008, Hasheela HHa0065 (WIND!).

HABITAT \& ECOLOGY. Barleria lichtensteiniana is recorded from open areas in dry riverbeds with sandy and/or stony soils and amongst rocks on both plains and at the foot of or on hillslopes. It prefers full sun and is associated with dwarf shrubland, sparse grassland or bare ground; 700 - 1700 m elevation. In Namibia, it occurs primarily in the Karas Dwarf Shrubland vegetation type of Mendelsohn et al. (2002), and falls within Craven's (2009) Gordonia floristic group.

CONSERVATION STATUS. This species is rather frequent and widespread in the drier regions of the Northern Cape Province of South Africa and southeast Namibia. The EOO is in excess of $163,000 \mathrm{~km}^{2}$. It is not considered to be globally threatened and is assessed as of Least Concern - LC.

NOTES. Masters (1870) describes and illustrates (his Fig. 13) the cleistogamous flowers that occur regularly in this species, in which the stigma is held within the short corolla tube by the constriction below the anthers, the style extending in a u-shaped bow beyond the unopened lobes.

Marloth (1932) notes that the entire inflorescence in this species "when ripe...becomes detached and rolls about in the wind like a rose of Jericho or a plant of Leucas" (p. 172). This is one of several species in the genus, including Barleria capitata, B. macrostegia and possibly B. carruthersiana in Angola and Namibia, in which the inflorescence axes curve upwards at fruiting so that the inflorescences become inrolled which would potentially aid dispersal by detachment and rolling along the ground (Darbyshire 2015: 75).

Although Lichtenstein s.n. would have been the most obvious choice for lectotypification of the name Barleria lichtensteiniana, the original material seen by Nees at Berlin was unfortunately destroyed during the Berlin bombing in World War II and the extant duplicate of this collection at GZU is only a small scrap. We have therefore selected the G-DC sheet of Burchell 2068 as the lectotype since it is informative material with an excellent duplicate at $\mathrm{K}$.

15. Barleria macrostegia Nees (1847: 235); Clarke (1901: 50); Dinter (1918: 347); Obermeyer (1933: 159); Meyer (1957: 382; 1968: 16); Balkwill \& Balkwill (1997: 557, Figs. 6F, G a 9D 6 ); Craven (1999: 152); Welman (2003: 94); Klopper et al. (2006: 4); Darbyshire et al. (2012: 765); Klaassen \& Kwembeya (2013: 129); Darbyshire (2015: 76). Type: South Africa, [Katrivier] Vet R., in bud Feb., year not recorded, Burke s.n. [cited in error as Burchell in the protologue] (holotype K! [K000394587]; isotype GZU* [GZU000250925]).

Barleria burchelliana Nees (1847: 235). Type: South Africa, [Fat] Vet R., fl. March, Burke 457 [cited in error as Burchell 457 in the protologue] (lectotype K! [K000394589], selected by Darbyshire (2015: 76); isolectotype K! [K000394588], labelled as 451 in error). 

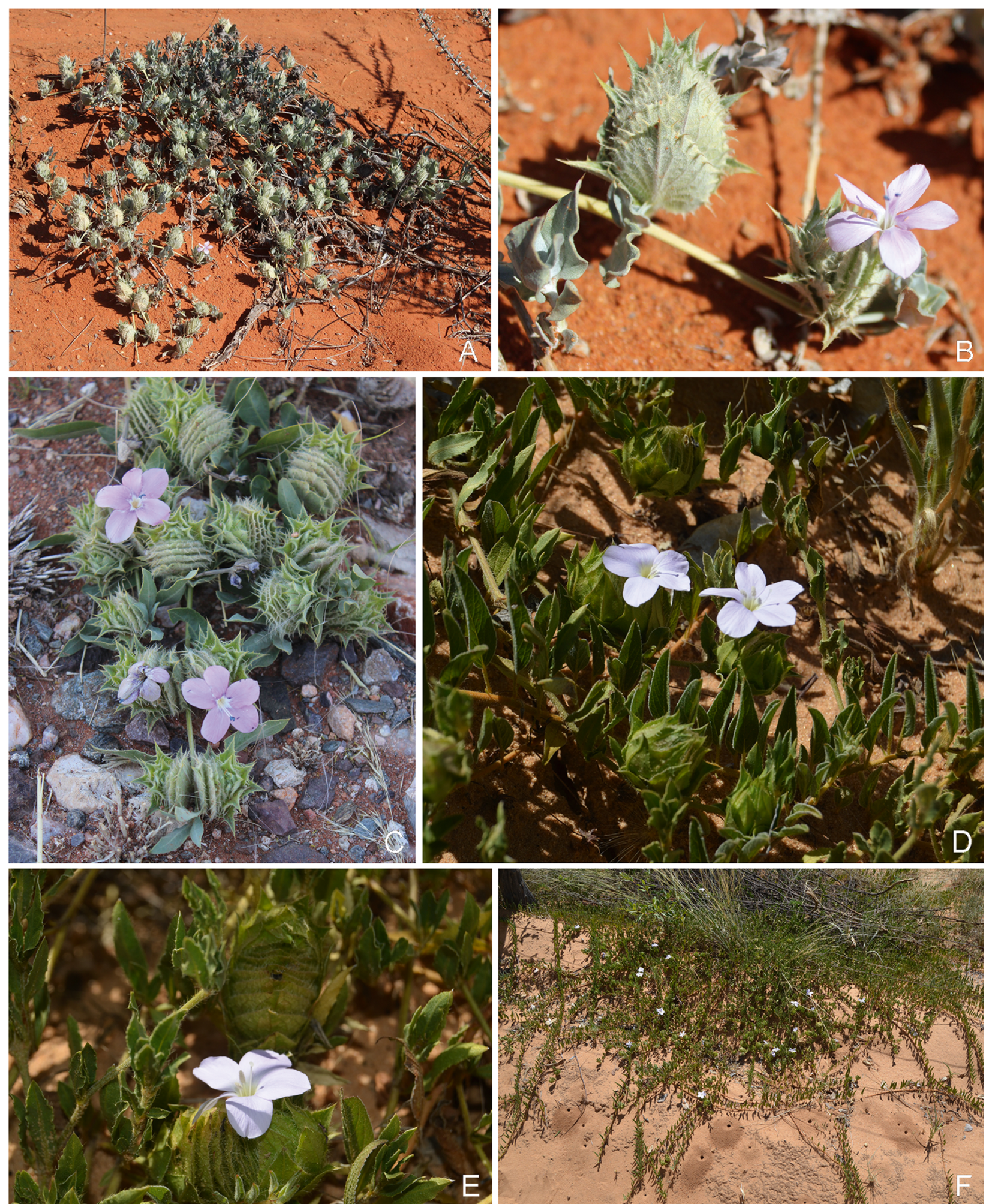

Fig. 8. A - C Barleria lichtensteiniana. A habit; B \& C flowering branches. D - F B. macrostegia. D \& E flowering branches; F habit. PHOTOS: A - C W. FRONEMAN, SOUTH AFRICA; D - F L. NANYENI, NAMIBIA.

Barleria burkeana Sond. (Sonder 1850: 92) "= B. burchelliana et macrostegia N. ab Es. l.c. p. 235 (species non diversae)"; T. Anderson (1863: 31) nom. superfl., see note in Darbyshire (2015: 76). 


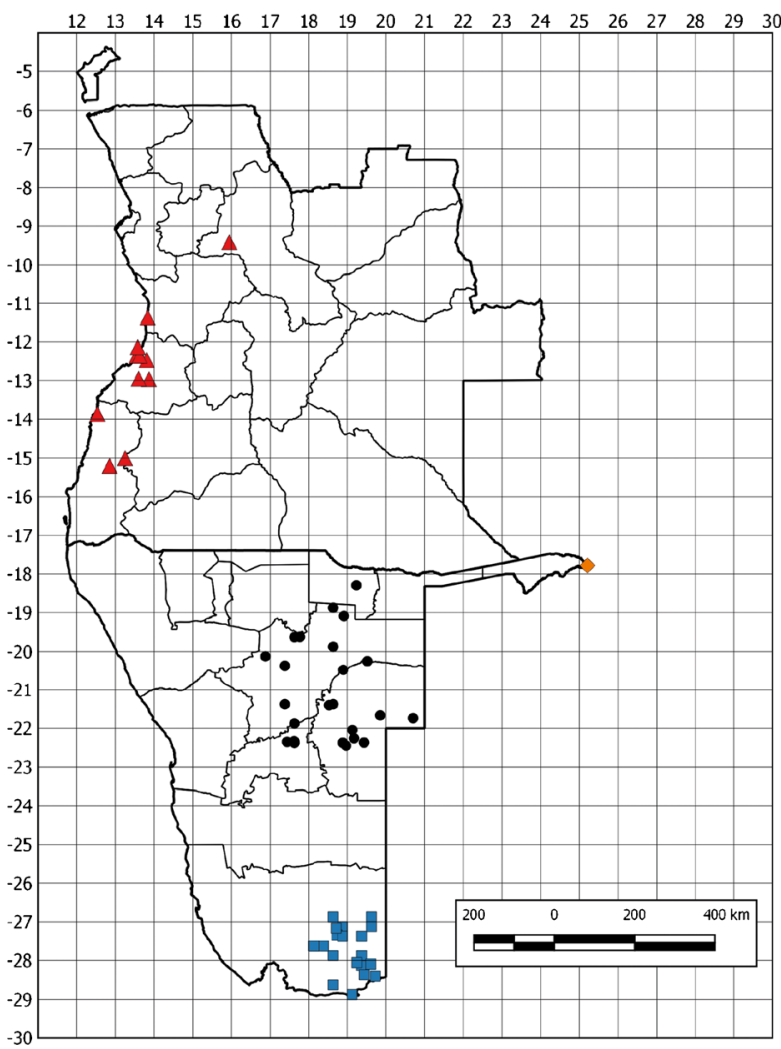

Map 6. Distribution of Barleria carruthersiana (red triangles), B. macrostegia (black circles - Namibian range only), B. lichtensteiniana (blue squares - Namibian range only) and $B$. capitata (orange diamond - Namibian range only).

Perennial herb with much-branched prostrate stems 15 $50 \mathrm{~cm}$ long from a woody base and rootstock; stems with short white retrorse hairs often in two opposite rows, and with few to numerous \pm spreading yellowish hispid hairs. Leaves often clustered on short lateral branches, narrowly oblong, (ovate-) elliptic or lanceolate, $0.8-3.5 \times 0.3-$ 0.7 (- 1) cm (1:w ratio (2 -) $2.5-5(-5.6): 1)$, base cuneate, margin thickened and often pale, apex acute, mucronate, margin and midrib beneath yellowish-hispid, hairs along margin with a \pm bulbous base forming minute serrations; lateral veins indistinct, midrib prominent beneath; petiole $0-4 \mathrm{~mm}$ long. Inflorescences axillary, dense cylindrical or subglobose unilateral cymes $2-7.5 \mathrm{~cm}$ long in the upper leaf axils, 4-10+-flowered; axis sometimes inrolled at fruiting; bracteoles imbricate and largely enclosing the calyces, green, sometimes with white margin, \pm broadly ovate, $(15-) 20-32 \times(7-) 10-$ $20 \mathrm{~mm}$, margin entire or minutely toothed due to swollen hair bases, apex spinulose, surface tripliveined or palmately veined, main veins and margin hispid; paired reduced sterile bracteoles sometimes present at lower nodes. Calyx green or mauve-tinged, later scarious, accrescent; anterior lobe suborbicular or somewhat ovate or elliptic, $15-21 \times 10-17 \mathrm{~mm}$ in flower, up to $25 \times 28 \mathrm{~mm}$ in fruit, base rounded or subcordate, margin entire or with minute teeth formed by swollen hair bases, apex obtuse, rounded or subattenuate and mucronulate, rarely bi-mucronulate, surface yellowish-hairy with softer hairs than leaves, dense along the margin; posterior lobe as anterior lobe but broadly ovate (-orbicular), $17-26 \times$ $11-18 \mathrm{~mm}$ in flower, up to $33 \times 29 \mathrm{~mm}$ in fruit, apex attenuate to obtuse, spinulose; lateral lobes lanceolate, $7-9 \mathrm{~mm}$ long in flower, up to $11.5 \mathrm{~mm}$ in fruit. Corolla 31 - $42 \mathrm{~mm}$ long, pale blue to purple with whitish tube, rarely white throughout, glandular-pilose externally; tube cylindrical, $18-28 \mathrm{~mm}$ long, somewhat expanded towards mouth; limb subregular; lobes (oblong-) obovate to elliptic, 9 - $15 \mathrm{~mm}$ long, abaxial and lateral lobes 5 $9.5 \mathrm{~mm}$ wide, adaxial lobes $4-7.5 \mathrm{~mm}$ wide, all with apices rounded. Stamens inserted 12.5 - $18 \mathrm{~mm}$ from base of corolla tube; filaments $8-12.5 \mathrm{~mm}$ long; anthers held at mouth or shortly exserted, 2 $2.8 \mathrm{~mm}$ long; lateral staminodes $1-3 \mathrm{~mm}$ long, pubescent at base, antherodes $0.3-1.3 \mathrm{~mm}$ long or absent. Ovary with ring of dense minute crisped white hairs at attachment point of style and extending onto style base; stigma broadly capitate, 0.6 $1.2 \mathrm{~mm}$ wide. Capsule 4-seeded, 14.5 - $17 \mathrm{~mm}$ long, glabrous; seeds $5-5.5 \times 5.5-6 \mathrm{~mm}$. Fig. $8 \mathrm{D}-\mathrm{F}$.

DISTRIBUTION. Northern Namibia (Kavango West, Khomas, Omaheke and Otjozondjupa Regions); Botswana, Zimbabwe, South Africa (Free State, Gauteng, Limpopo, Mpumalanga Northern Cape and NorthWest Provs.). Map 6.

SELECTED SPECIMENS EXAMINED. (Total of 30 Namibian collections seen): NAMIBIA. Farm Otjisauona North, 53 miles WSW of Steinhausen, fl. 20 Feb. 1955, de Winter 2419 (K!, M!, PRE, WIND!); 45 myl suid van Kantoor in Otjituuo Reservaat, fl. \& fr. March 1958, le Roux 184 (WIND!); Otjiwarongo Distr., Farm Osire- Süd, fl. 28 April 1959, Giess 2237 (M!, PRE, WIND!); Gobabis Distr., Farm Summerdown, fr. 14 July 1960, van Vuuren 1168 (K!, M!, PRE, WIND!); Windhoek Distr., road Windhoek - Steinhausen, farm Voigtskirch 135 c. 30 miles from Windhoek, fl. 11 March 1968, H. Eं H. E. Wanntorp 201 (K!); Grootfontein Distr., Farm Askevold, GR 525, Omuramba, fl. 3 Feb. 1969, Giess E Smook 10615 (M!, WIND!); Dist. Otjiwarongo, Waterberg-platopark, fr. 17 March 1977, Jankowitz Ja 1116 (WIND!); Otjozondjupa, Grootfontein Distr., Sonop Observatory Plot 111, fl. 26 April 2001, B. Eे M. Strohbach BS5213 (WIND!); Otjozondjupa, Okakarara Distr., Omuramba, fr. 10 May 2001, Uiras MU329 (WIND!); Omaheke, Farm Annaboom, fl. 7 March 2002, Uiras MU493 (WIND!); Omaheke, D1603 road to the Botswana border, fl. 8 March 2002, Uiras MU514 (WIND!); Grootfontein Distr., Farm Gauss 46, $21 \mathrm{~km} \mathrm{~S}$ on road D2863 from junction with road D3022, fl. \& fr. 23 May 2005, Kolberg $\mathcal{E}^{\circ}$ Tholkes HK2241 (WIND!). 
HABITAT \& ECOLOGY. Barleria macrostegia occurs in open to more dense dry bushland typically with Acacia spp., grassland, bare earth particularly on compacted soils and pans, and sometimes in disturbed areas such as roadsides; $1150-1800 \mathrm{~m}$ elevation. It is recorded from the North-eastern Kalahari Woodland, Northern Kalahari, Central Kalahari and Thornbush Shrubland vegetation types of Mendelsohn et al. (2002).

CONSERVATION STATUS. This is a widespread species with an EOO in excess of 1 million $\mathrm{km}^{2}$. It is fairly common over much of its range, and tolerant of or even favouring moderate habitat disturbance. It is assessed as of Least Concern - LC.

16. Barleria capitata Klotzsch (1861: 210); Clarke (1899: 153), pro parte excl. Schweinfurth 1071 ex Eritrea; Klopper et al. (2006: 4); Darbyshire et al. (2012: 765); Klaassen \& Kwembeya (2013: 129); Darbyshire (2015: 74). Type: Mozambique, Rios de Sena, imm. infl., without date $(1842$ - 1846), Peters s.n. (B† holotype; PRE* isotype).

Barleria megalosiphon Mildbr. (Mildbraed 1930: 62); Obermeyer (1933: 158); Craven (1999: 152); Welman (2003: 94); Klopper et al. (2006: 4). Type: Zimbabwe, Victoria Falls, fl. Jan. 1923, E. H. Wilson s.n. (AAH* [A00444623] lectotype, selected here) see note.

Spiny subshrub with spreading, decumbent or subprostrate branches 20 - $70 \mathrm{~cm}$ long; stems with dense short white antrorse or mixed antrorse and retrorse hairs, interspersed with few subappressed long pale hairs. Leaves often clustered on short lateral branches, elliptic or oblanceolate, $1.8-4 \times 0.5-$ $1.3 \mathrm{~cm}$ (l:w ratio 2.2 - 3.6:1), base cuneate or attenuate, margin entire, apex acute or obtuse, mucronate, surfaces with pale coarse (sub)appressed hairs most numerous on veins beneath, young leaves also with minute curled white hairs; lateral veins $3-4$ pairs; petiole to $6 \mathrm{~mm}$ long. Inflorescences contracted unilateral cymes $3-7 \mathrm{~cm}$ long in upper axils, each $3-$ 10+-flowered, axis usually inrolled at maturity; bracteole pairs unequal, the larger held erect or horizontal, lanceolate, $18-30 \times 5-11 \mathrm{~mm}$, asymmetric and falcate, margin with numerous slender flexuose spines, apex spinose, midrib pale and prominent, smaller bracteole in each pair declinate; reduced sterile pale-scarious bracteoles present at lower nodes, lanceolate or ovate, $6-15 \times 1.5-5$ excluding lateral spines. Calyx drying brown-black, tardily brownscarious; anterior lobe broadly ovate, $28-32 \times 15-$ $16 \mathrm{~mm}$, base rounded or cordate, margin with \pm numerous spreading bristles thickened at maturity and forming marginal laciniae, apex acute, surface with sparse ascending or spreading hairs along the veins and with minute white curled hairs at least when young; posterior lobe as anterior lobe but $32-42 \times 21$ - $23 \mathrm{~mm}$, apex shortly spinose, surface with conspicuous flexuose submarginal spines $3-5.5 \mathrm{~mm}$ long; lateral lobes subulate, $14-17 \mathrm{~mm}$ long, apices acute to rounded, surface with long subappressed hairs especially along margin and scattered short glandular hairs. Night flowering, flowers wilting the following morning. Corolla white, drying blue-black, glandularpilose externally, limb also with shorter eglandular hairs; tube narrowly cylindrical, $(80-) 100-130 \mathrm{~mm}$ long; limb subregular, lobes elliptic or ovate-elliptic, $13-23 \times 10-18 \mathrm{~mm}$ or adaxial lobes somewhat smaller, apices acute to rounded or abaxial lobe shallowly emarginate. Stamens inserted in upper third of corolla tube; filaments 31 - $35 \mathrm{~mm}$ long; anthers shortly exserted, $4-5 \mathrm{~mm}$ long; lateral staminodes $0.7-3.5 \mathrm{~mm}$ long, pilose, antherodes to $0.7 \mathrm{~mm}$ long or obsolete. Ovary shortly pubescent towards apex and with a ring of dense minute crisped white hairs at attachment point of style; style puberulous towards base; stigma subcapitate, $0.5-0.8 \mathrm{~mm}$ long. Capsule 4seeded, $\pm 21 \mathrm{~mm}$ long, antrorse-puberulous towards apex; seeds $\pm 6.5 \times 6 \mathrm{~mm}$. Fig. $9 \mathrm{~A}-\mathrm{C}$.

DISTRIBUTION. Northeastern Namibia (Zambezi Region); Zambezi River catchment in Mozambique, Malawi, Zambia, Zimbabwe and Botswana. Map 6.

SPECIMEN EXAMINED. NAMIBIA. E Caprivi Zipfel, Mpilila Island, fl. 13 Jan. 1959, Killick Eॄ Leistner 3354 (K!, M!, PRE, WIND!).

HABITAT \& ECOLOGY. Barleria capitata is recorded in Namibia as locally common in woodland at c. $900 \mathrm{~m}$ elevation in the Zambezi Region (formerly Caprivi Strip). It is a species of the Zambesian Regional Centre of Endemism of White (1983), which corresponds to the Zambesian Domain floristic group of Craven (2009).

CONSERVATION STATUS. Darbyshire (2015) noted that this species is widespread but scattered and apparently rather scarce in the Zambezi catchment, but is considered likely to be of Least Concern - LC. The EOO has not been fully delimited but is sure to be in excess of $50,000 \mathrm{~km}^{2}$. It was recorded as locally common in woodland on Mpilila Island on the single known collection from Namibia. However, the woodlands here and in surrounding areas of the Zambezi Region have been widely degraded due to human encroachment and this species is likely to be nationally threatened in Namibia under IUCN criterion $\mathrm{B}$.

NOTES. This is a truly impressive species, with flowers over $10 \mathrm{~cm}$ long. The long-tubular white corollas that only open in the evening and wither the following morning are almost certainly moth pollinated.

In the protologue of Barleria megalosiphon, Mildbraed noted that he had seen two duplicates of the type collection, one in the Arnold Arboretum 

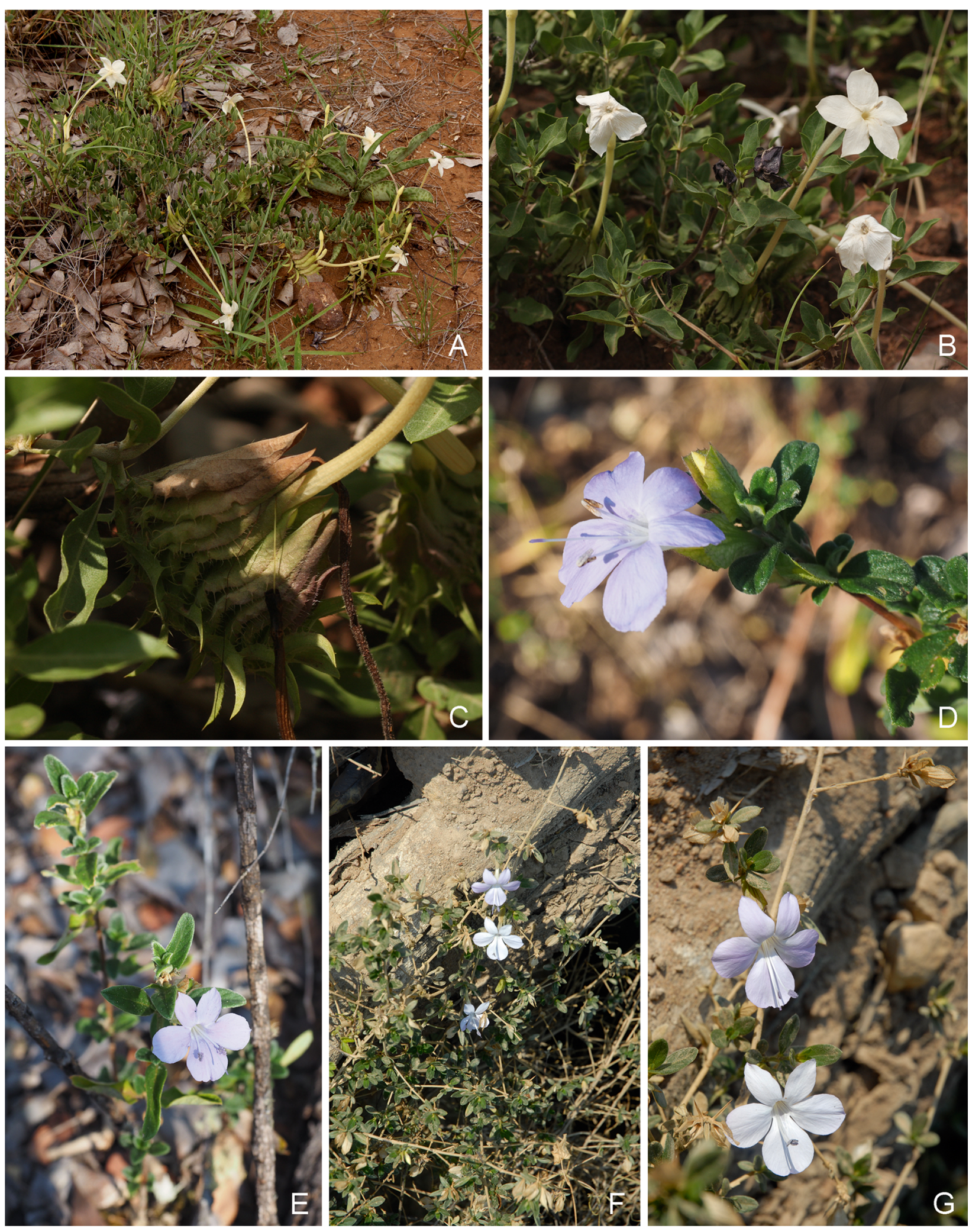

Fig. 9. A - C Barleria capitata. A habit; B flowers; C detail of inflorescence. D \& E B. crassa subsp. crassa, flowering branches. F \& $G$ B. rupicola. F habit; G flowering branch. D \& E Goyder 8076 (Angola); F \& G Goyder et al. 7541 (Angola). PHOTOS: A - C B. WURSTEN, ZIMBABWE; D - G D. J. GOYDER. 
Herbarium and one in the Berlin Herbarium; the latter duplicate was destroyed during the bombing of Berlin in World War II and so the former is selected as the lectotype here.

17. Barleria crassa C. B. Clarke (1899: 151); Klopper et al. (2006: 4); Darbyshire (2010b: 339; 2015: 53). Type: Zimbabwe, South African Goldfields, fl. 1870, Baines s.n. (holotype K! [K000394567]).

Barleria venosa Oberm. (Obermeyer 1933: 168). Type: Zimbabwe, [date unknown], van Son in Vernay-Lang Kalahari Expedition s.n. (holotype PRE, n.v.).

Spiny shrub or perennial herb, $45-250 \mathrm{~cm}$ tall; stems buff- or yellowish-strigose with interspersed shorter spreading hairs when young. Leaves subsessile, rather fleshy, (oblong-) elliptic, obovate or suborbicular, $0.7-4.5 \times 0.4-1.8 \mathrm{~cm}$ (1:w ratio $1.2-3.6: 1)$, base cuneate or subattenuate to obtuse, margin entire, revolute when young, apex obtuse, rounded or rarely acute, with a short spine-tip or apiculum, upper surface with coarse subspreading to subappressed hairs, lower surface strigulose on the veins and with numerous spreading whitish hairs elsewhere at least when young; lateral veins $3-6$ pairs, prominent beneath. Inflorescences axillary and/or subterminal, 1 - 3-flowered, subsessile; bracteoles spinose, $5-18 \times$ $0.5-2.5 \mathrm{~mm}$, straight or curved, conduplicate or triangular in cross section, margin entire, pairs sometimes persisting at lower nodes as paired axillary spines. Calyx often purplish towards apex and on veins when young, later turning pale-scarious; anterior and posterior lobes subequal, broadly ovate to elliptic or obovate, $10.5-23 \times 5-16 \mathrm{~mm}$, base rounded or cordate to cuneate or attenuate, margin denticulate to spinulose-dentate, more rarely subentire, apex obtuse to attenuate in outline, \pm spine-tipped, anterior lobe rarely emarginate, surfaces sparsely strigulose and with scattered minute stalked glands; lateral lobes lanceolate-attenuate, 3 $8.5 \mathrm{~mm}$ long. Corolla (22.5 -) 25 - $38.5 \mathrm{~mm}$ long, blue, mauve or white, glandular-pilose externally or largely glabrous; tube 15 - $23.5 \mathrm{~mm}$ long, funnelshaped above attachment point of stamens; limb in " $2+3$ " configuration; abaxial lobe orbicular or obovate, $9-16 \times 8-16.5 \mathrm{~mm}$, apex rounded or emarginated; lateral lobes as abaxial lobe but sometimes more elliptic, up to $18 \times 15.5 \mathrm{~mm}$, apex sometimes subattenuate; adaxial lobes elliptic, 6 $15 \times 4-10 \mathrm{~mm}$, apex rounded or often acute to subattenuate. Stamens inserted 6-12 mm from base of corolla tube; filaments $12-24 \mathrm{~mm}$ long; anthers 3 - $5 \mathrm{~mm}$ long; lateral staminodes 0.7 - $3.7 \mathrm{~mm}$ long, with minute stalked glands and often pilose, antherodes to $1.4 \mathrm{~mm}$ long or barely developed. Ovary glabrous; style with declinate straight hairs at base; stigma linear, 1 - 2 mm long. Capsule 4-seeded, (11.5 -) 14.5 - 17 mm long, glabrous; only immature seeds seen.

Barleria crassa C. B. Clarke subsp. crassa; Darbyshire (2015: 55).

Barleria spinulosa sensu auctt., non Klotzsch: Moore (1930: 134), pro parte quoad Gossweiler 3013; Balarin et al. (1999: 178, 192).

Leaves with spine tip minute. Calyx often purplish when young; outer lobes \pm broadly ovate, $11.5-22$ ($34) \times(7-) 9-13(-18) \mathrm{mm}$, shortly attenuate into a rounded, truncate or subcordate base, margin denticulate with apiculate teeth or subentire, rarely spinulose-dentate; lateral lobes 4.5 - $8 \mathrm{~mm}$ long. Corolla (pale) blue, mauve or purple, pilose to sparsely so externally; tube (17.5 -) 19.5 - $23.5 \mathrm{~mm}$ long; abaxial and lateral lobes 10 - $16 \mathrm{~mm}$ long; adaxial lobes 7.5 - $13.5 \mathrm{~mm}$ long. Lateral staminodes 0.7 $2.5 \mathrm{~mm}$ long, pilose at least towards base; antherodes usually well-developed, $0.7-1.4 \mathrm{~mm}$ long, rarely absent. Fig. 9D \& E.

DISTRIBUtION. Angola (Cuando Cubango and Moxico Provs.); Malawi, Zambia and Zimbabwe (species as a whole also in Tanzania). Map 7.

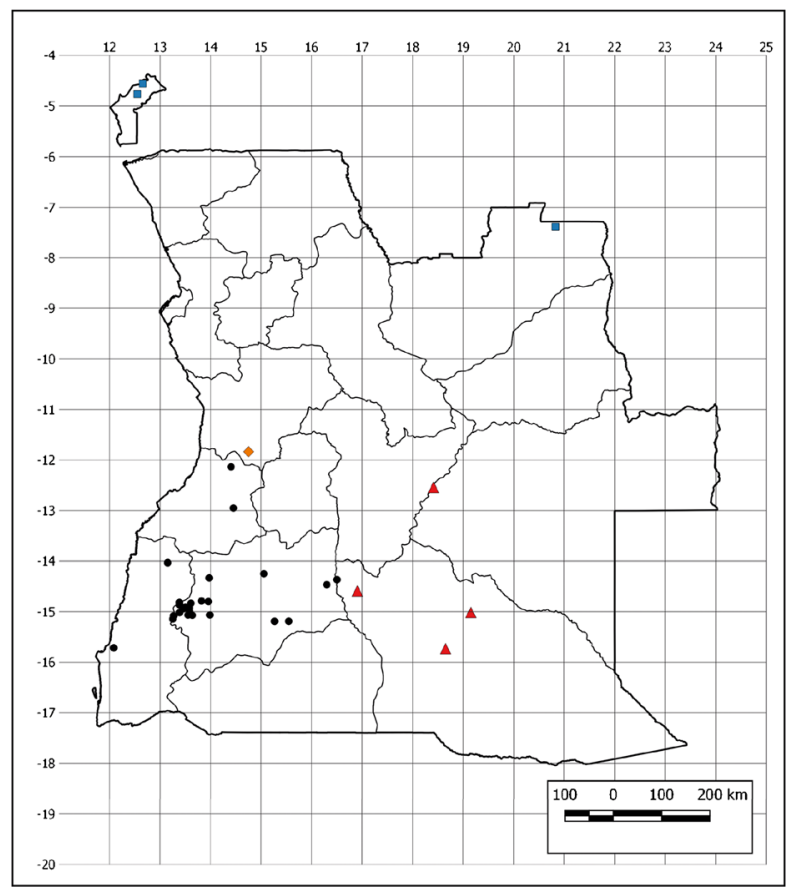

Map 7. Distribution of Barleria crassa subsp. crassa (red triangles - Angolan range only), B. rupicola (black circles), $B$. namba (orange diamond) and $B$. brownii (blue squares Angolan range only). 
SPECIMENS EXAMINED. ANGOLA. Kampuluvé, Kuito, fl. 4 April 1900, Baum 795 (BM!, K!); T'Chirandongambe R., Luassingua, fl. \& fr. 14 April 1906, Gossweiler 3013 (BM!); Lukona to almost as far west as Menongue (Serpa Pinta), fl. \& fr. May - Aug. 1925, Pocock 201 (BOL!); Moxico, track heading N from source of Cuito R. towards Munhango, fl. 23 May 2015, Goyder 8028 (K!, LUBA!, PRE!); Cuando Cubango, Cuchi R. gorge, N of Cuchi, fl. 29 May 2015, Goyder 8076 (K!, LUBA!, PRE!).

HABITAT \& ECOLOGY. This subspecies occurs in miombo woodland on sandy soils and on rock outcrops; 1350 $1550 \mathrm{~m}$ elevation. It is a species of the Zambesian Regional Centre of Endemism (White 1983).

CONSERVATION STATUS. This is a widespread taxon, fairly common on rock outcrops in the miombo woodlands of Zambia and Zimbabwe in particular. The EOO is not fully delimited but is believed to be in excess of $500,000 \mathrm{~km}^{2}$. M. Pocock's record from Angola suggests that it is widespread in the southeast of the country and it was noted as fairly frequent along the Cuito catchment by D. Goyder (pers. comm.). It was assessed as of Least Concern - LC by Darbyshire (2010a, 2010b; 2015).

NOTES. The Pocock collection cannot be placed with certainty, as Lukona is in West Zambia whilst Menongue is some hundreds of kilometres to the west in South-Central Angola (see Balarin et al. 1999). It suggests that this species is widespread in Southeast Angola.

As noted by Darbyshire (2015), the material from west Zambia and Angola differs somewhat from specimens from the core of this taxon's range further west in having larger and less fleshy leaves; this is likely to be an ecological adaptation as it is less restricted to rock outcrops in the west. The typical form from Zambia and Zimbabwe is pictured in Fig. 2C of Darbyshire \& Luke (2016).

18. Barleria rupicola I. Darbysh. sp. nov. Type: Angola, Huíla, prox. de Sá da Bandeira [Lubango], nas faldas da Serra do Lubango, fl. 5 July 1962, Barbosa E Moreno 10271 (holotype K! [K001009481]; isotype PRE!).

http://www.ipni.org/urn:lsid:ipni.org:names:60477548-2

Barleria kirkii sensu Moore (1880: 265), non T. Anderson.

Barleria grandicalyx Lindau var. vix-dentata C. B. Clarke (1899: 149), pro parte quoad spec. ex Angola; \& sensu auctt.: Hiern (1900: 814); Makholela (2008: 21); non B. grandicalyx var. vix-dentata sensu stricto, lectotypified by Darbyshire (2010b: 334).

Barleria grandicalyx sensu Benoist (1950: 15), non Lindau.
Barleria spinulosa sensu auctt., non Klotzsch: Moore (1930: 134), pro parte excl. Gossweiler 3013; Benoist (1950: 15); Makholela (2008: 22).

Perennial herb or subshrub, much-branched from towards the woody base, prostrate or decumbent, then $30-100 \mathrm{~cm}$ tall; stems with dense appressed or antrorse yellow-buff hairs, or sometimes spreading and with a swollen base, also with shorter, finer retrorse or spreading whitish hairs on two opposite sides. Leaves sessile or petiole to $4 \mathrm{~mm}$ long; blade elliptic, lanceolate or ovate, more rarely somewhat obovate when young, $1.5-4.5 \times 0.5-1.8 \mathrm{~cm}$ (l:w ratio $2.2-$ $3.2: 1)$, base cuneate, attenuate or obtuse, margin entire, revolute particularly when young, apex acute or rarely rounded when young, mucronulate; margin and veins beneath yellow-buff strigose, with dense finer spreading whitish or brown hairs between veins when young, upper surface antrorse-hairy; lateral veins (3-) $4-5(-6)$ pairs, prominent beneath, reticulate tertiary venation also conspicuous beneath at least when young. Inflorescences of axillary and subterminal single- or rarely 2-flowered cymes, often crowded on short lateral branches, sessile or peduncle to $3 \mathrm{~mm}$ long; bracteoles linear or lanceolate, $5-14 \times 1-3$ $\mathrm{mm}$, triangular or conduplicate in cross section, margin entire or with minute teeth formed by swollen hair bases, apex spinose or shortly so. Calyx mauvebrown, sometimes paler towards base and centre of outer lobes, with prominent palmate-reticulate venation, turning pale brown-scarious in fruit; anterior and posterior lobes subequal, obovate or elliptic, $11-18 \times$ $5-10.5 \mathrm{~mm}$, base cuneate or attenuate, margin spinulose-dentate, teeth with an apical bristle, more rarely subentire, apex rounded or truncate to shortly attenuate in outline, with $1-3$ short spines or teeth, external surface with (sub)appressed buff or yellowbuff hairs mainly along main veins, with or without scattered short patent glandular hairs; lateral lobes linear-lanceolate, 7.5 - $11.5 \mathrm{~mm}$ long. Corolla white or lilac to purple, (26 -) 29 - $44 \mathrm{~mm}$ long, glandularpilose and with short subappressed eglandular hairs externally; tube 18 - $26.5 \mathrm{~mm}$ long, narrowly funnelshaped above attachment point of stamens, cylindrical below; limb in " $2+3$ " configuration; abaxial lobe obovate, $(8-) 11$ - $15.5 \times(7-) 8.5$ - $13 \mathrm{~mm}$, apex emarginate or truncate; lateral lobes elliptic, rounded or obovate, $(7.5-) 9-15.5 \times(6-) 8-14.5 \mathrm{~mm}$, apices rounded, truncate or acute; adaxial lobes elliptic, (6-) $9-13 \times(4.5-) 5.5-9.5 \mathrm{~mm}$, apices obtuse or acute. Stamens inserted in lower half of corolla tube; filaments 17 - $31 \mathrm{~mm}$ long; anthers exserted, 3 - $4 \mathrm{~mm}$ long; lateral staminodes $2-3 \mathrm{~mm}$ long, filaments pilose, antherodes $1-1.2 \mathrm{~mm}$ long. Ovary glabrous; style with tuft of declinate pale hairs at base or sparsely so; stigma linear or clavate, 0.8 - $1.4 \mathrm{~mm}$ long, apex with $2 \pm$ uneven lobes. Capsule 4-seeded, 15.5 - 
$18.5 \mathrm{~mm}$ long, glabrous; immature seeds only seen. Figs $9 F$ \& G, 10.

RECOGNITION. Barleria rupicola resembles Barleria crassa but differs in (i) having a more trailing or spreading habit; (ii) the mature leaves being acute at the apex, vs obtuse to rounded in $B$. crassa (both have a short mucro); (iii) the corolla tube being more narrowly funnel-shaped above the insertion of the stamens, and can appear largely cylindrical in living material, vs always funnel-shaped in B. crassa; (iv) the young calyx drying a dark purplish-brown at least in the upper half and towards the margins (vs green or mauve in B. crassa) and having a finer reticulate venation; and (v) the lateral calyx lobes being 7.5 - $11.5 \mathrm{~mm}$ long and usually more than half as long as the outer lobes (vs $3-8.5 \mathrm{~mm}$ and less than half as long in B. crassa). DISTRIBUTION. Endemic to southwestern Angola (Benguela, Huíla and Namibe Provs.). Map 7.

ADDITIONAL SPECIMENS EXAMINED. ANGOLA. Between Lopollo and Catumba, fl. March 1860, Welwitsch 5048 (BM!, LISU!); Humpata, fl. Sept. 1883, H. H. Johnston s.n. (K!); bei Goudkopze am Chitanda, fl. 22 May 1900, Baum 939 (BM!, K!, M!); near Candimba R., Cuelai - Ganguellas, fl. 26 April 1906, Gossweiler 2686 (BM!, K!, ?LISC! without data); Gimbundo Jamaiambe, Kutoto R., fl. 2 May 1906, Gossweiler 3800 (BM!, K!); near Fort Princeza Amelia, Kubango, fl. 19 May 1906, Gossweiler 3860 (BM!, K!); Gimbundo Jamaiambe, Kutoto, Kubango, fl. July 1906, Gossweiler 3977 (BM!, K!, LISC!); near [Huilla] Huíla Mission Station, fl. 11 May 1909, Pearson 2722 (K!); Leba, fl. 20 June 1937, Exell Eॄ Mendonça 2954 (BM!); Serra da Chela, st. 17 May 1937, Gossweiler 10793 (LISC!); between Sá de Bandeira [Lubango] and Huíla, fl. 22 June 1937, Gossweiler 10643 (BM!); Serra da Chella, aux environs de Sá da Bandeira (Lubango), fl. Aug. 1937, Humbert 16253 (BM!, K!, P); vallée du R. Koroka, E of Porto Alexandre [Tômbwa], fl. Aug. 1937, Humbert 16354 (BM!, P); Serra da Chella, aux environs de Humpata, fl. Aug. 1937, Humbert 16591 (BM!, P); Cubal, Capacca (Membassõco), 218 km inland, fl. \& fr. May 1941, Faulkner A.362 (BM!, K!, PRE!); Lukundu, Tschiwinguru, fl. May 1954, Boss s.n. (M!); Tschitundo Lulo, südlich des R. Cubal, fl. June 1954, Boss s.n. (M!); Leba, fl. \& fr. 30 July 1954, Pritchard 334 (BM!, LISC!); Sá da Bandeira [Lubango], Senhora do Monte, fr. July 1956, Teixeira 1545 (LUBA!, PRE!); Leba, Humpata, fl. 20 May 1958, Teixeira 3551 (PRE!); Huíla, Sá da Bandeira [Lubango], Tchimucua, fl. 19 June 1959, Correia 605 (LUBA!); Huíla - Lutondo (Quilengues), fl. 23 June 1959, Correia 723 (LUBA!); a 39 km de Sá da Bandeira [Lubango] para Vila de Paiva Couceiro (Quipungo), fl. 1 June 1962, Barbosa E Moreno 10228 (K!, LUBA!); Huíla, Sá da Bandeira [Lubango], Mapunda, fl. 12 June 1963, R. Santos 1115 (K!, LUAI!);
Alto Cunene, na estrada Mulondo - Capelango ao km 51, fr. 12 Oct. 1963, de Menezes 874 (K!, LUBA!, PRE!); Huíla, Lubango, próx. da Tundavala, fl. 12 May 1964, de Menezes 1092 (LUBA!); Huíla, Sá da Bandeira [Lubango], ?Meteha, fl. 17 June 1964, Sousa 524 (LUAI!); Sá da Bandeira [Lubango], na avenida da Pousada de Turismo, fl. 4 June 1965, J. Santos s.n. (LUAI!); Huíla, entre Caconda e Matala, fl. bud 21 June 1965, Correia 2999 (LUBA!); Huíla, Sá da Bandeira [Lubango] - Hoque, fl. 8 May 1966, de Sousa 1198 (LUAI!); Huíla, Cascata, margem do regato Lopolo, fl. 20 May 1966, Correia 3827 (LUBA!); Sá da Bandeira [Lubango], $\mathrm{km} \mathrm{16,} \mathrm{na} \mathrm{estrada} \mathrm{para}$ Quipungo (ao km 12), fl. 24 May 1966, Henriques 993 (BM!, K!, PRE!); Huíla, Lubango, próx. da Escola Marques de Sá da Bandeira, fl. 7 June 1972, Couto 231 (LUBA!); Huíla, Lubango, ao km 26 da estrada Sá da Bandeira [Lubango] - Chibia, fl. 12 June 1975, Borges et al. 446 (LUBA!); Lubango, Mukankha, ao km 14, fl. \& fr. 17 July 1994, Daniel 2432 (LUBA!); Lubango area, Tchivinguiro Gorge c. 20 km SW Humpata, fl. 12 Oct. 2013, Goyder et al. 7541 (K!, LUBA); Namibe, Serra de Chela/Leba between Namibia and Lubango but within $60 \mathrm{~km}$ of Lubango, fl. 23 April 2017, Tripp Ẽ Dexter 6997 (COLO!, K!, LUBA!).

HABITAT \& ECOLOGY. Barleria rupicola is found on rocky soils and amongst boulders on hillslopes with dry bushland or secondary dry forest, in open woodland, on termitaria or on hard clay; $(50-) 1000-2400 \mathrm{~m}$ elevation. It is a species primarily of the Colophospermum mopane woodland zone of southwest Angola, with less frequent outliers in desert areas. Its range is centred on the Huíla plateau, a known centre of plant endemism (Exell \& Gonçalves 1973; Linder 2001; Figueiredo 2008).

CONSERVATION STATUS. Although restricted to southwestern Angola, this species is fairly widespread there with an EOO of $90,868 \mathrm{~km}^{2}$, and is locally common to abundant in suitable habitat particularly in the region of Lubango (Couto 231; D. Goyder, pers. comm.). Threats are considered to be low in view of the fact that it favours dry rocky sites, often growing amongst boulders, although browsing by livestock may impact some local populations. It is assessed as of Least Concern - LC.

ETYMOLOGY. The species epithet "rupicola", meaning "rock-dwelling", refers to this species' preference for rock outcrops and rocky slopes.

NOTES. Barleria rupicola replaces the widespread B. crassa C. B. Clarke on rocky slopes in western Angola. The two are clearly closely allied but are easily separated by comparison in the herbarium. The most consistent diagnostic characters are listed in the Recognition section. However, in practice, B. rupicola is most easily separated from most populations of B. crassa, including those from Angola, by the obovate or elliptic calyx lobes with a gradually cuneate or 


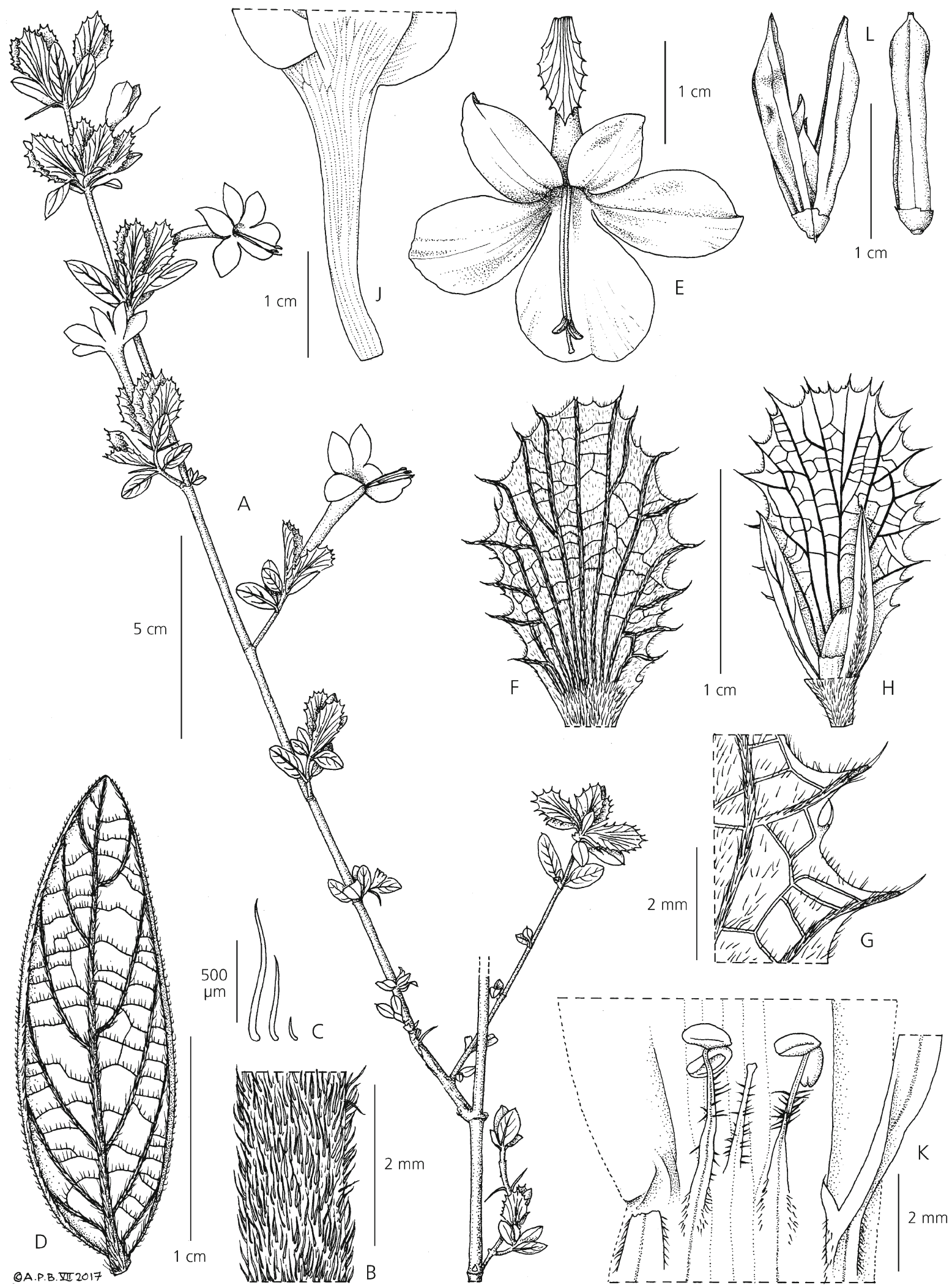

Fig. 10. Barleria rupicola. A habit; B stem indumentum; C detail of different stem hair types; D leaf, abaxial surface; $E$ flower in face view; F posterior calyx lobe, external surface; $\mathrm{G}$ detail of margin of posterior calyx lobe; $\mathrm{H}$ anterior and lateral calyx lobes with ovary in situ; J corolla tube, ventral surface to the right; K staminodes; L capsule in face and lateral views. A - C, K Barbosa et al. 10271, D \& J Faulkner A.362, E from photograph by D. Goyder, F - H Barbosa 10228, L Goyder et al. 7541. DRAWN BY ANDREW BROWN. 
attenuate base, vs broadly ovate with a rounded, truncate or cordate base in B. crassa. The only exception to this rule is B. crassa subsp. ramulosoides I. Darbysh., recently described from East Zambia (Darbyshire 2015), which has elliptic or obovate calyces. It is nevertheless easily separated from B. rupicola by, in addition to the characters listed under Recognition, its more shrubby habit, with leaves and persistent spinose bracteoles crowded between short internodes, a more conspicuous mucro on the leaf tip, and larger anthers, $4-5 \mathrm{~mm}$ long.

19. Barleria namba I. Darbysh. sp. nov. Type: Angola, Cuanza Sul Prov., Mt Namba, c. $34 \mathrm{~km} \mathrm{~W}$ of Cassongue, $\mathrm{N}$ face of mountain above Kanhala village, fl. 12 June 2016, Goyder, Maiato Ẽ Luis 8660 (holotype $\mathrm{K}$ ! [K001295764]; isotype LUBA).

http://www.ipni.org/urn:Isid:ipni.org:names:60477549-2

Spreading subshrub, much branched, to $60 \mathrm{~cm}$ tall; stems reddish-brown, densely pale-buff pubescent with mixed long ascending bulbous-based hairs and shorter more spreading hairs, both most dense on two opposite sides. Leaves sessile or petiole to $4 \mathrm{~mm}$ long; blade (?only seen in immature state) elliptic or somewhat ovate, $2.7-4 \times 1.4-$ $1.9 \mathrm{~cm}$ (l:w ratio $1.8-2.1: 1$ ), base cuneate or obtuse, margin entire, apex acute, surfaces with numerous long pale buff hairs throughout and with interspersed shorter fine hairs beneath; lateral veins 4 pairs, prominent beneath, fine reticulate venation also conspicuous beneath, dark in dry state. Inflorescences of crowded terminal spikes on short lateral shoots, each comprising a series of sessile single-flowered cymes; bracts foliaceous but much reduced, $7-16.5 \times 3-8.5 \mathrm{~mm}$, apex spinulose, indumentum as leaves but with additional short glandular hairs; bracteoles linear-lanceolate, $11-14.5 \times 1.5-2 \mathrm{~mm}$, margin entire, apex spinulose, surface conduplicate, green with pale and prominent midrib, indumentum as bracts, glandular hairs numerous. Calyx green or purplish with conspicuous darker subparallel primary venation; anterior lobe elliptic or elliptic-lanceolate, $15-19 \times 5-$ $6.5 \mathrm{~mm}$ in flower, up to $22.5 \mathrm{~mm}$ long in young fruit, base cuneate, margin entire, somewhat involute, apex acutemucronate or unevenly notched, external surface with dense short viscid-glandular hairs and with interspersed eglandular hairs, these longest along the main veins and margin; posterior lobe as anterior lobe but more lanceolate, $18.5-21 \times 6-7 \mathrm{~mm}$ in flower, up to $24.5 \mathrm{~mm}$ long in young fruit; lateral lobes linearlanceolate, 13 - $15 \mathrm{~mm}$ long. Corolla white tinged pale pink-purple and with darker markings in throat, drying dark blue with darker venation, 39 - 41 mm long, glandular-pilose and eglandular-pubescent externally; tube $21-23 \mathrm{~mm}$ long, cylindrical in basal portion where $3-4 \mathrm{~mm}$ wide, campanulate above insertion point of stamens, mouth $7.5-8.5 \mathrm{~mm}$ wide; limb in marked " $2+3$ " configuration; abaxial lobe barely offset, broadly obovate, $16.5-17 \times 12.5-13 \mathrm{~mm}$, apex shallowly emarginate, lateral lobes elliptic or obovate-elliptic, $17-18.5 \times 9-11$ $\mathrm{mm}$, apices obtuse or rounded, adaxial lobes lanceolate $15.5-17 \times 3.8-5 \mathrm{~mm}$, pair fused in basal $4.5-5 \mathrm{~mm}$, apices markedly acute or attenuate. Stamens inserted 6 $6.5 \mathrm{~mm}$ from base of corolla tube; filaments $27-30 \mathrm{~mm}$ long; anthers exserted, 3.6 - $4 \mathrm{~mm}$ long; lateral staminodes 3-3.5 mm long, glabrous except for minute subsessile glands towards base, antherodes $0.7-1 \mathrm{~mm}$ long. Ovary with few pale straight hairs at apex; style glabrous; stigma subcapitate but slender, $0.25-0.3 \mathrm{~mm}$ long. Capsule only seen in immature state, apparently 4seeded, glabrous except for a few minute hairs at apex. Figs 11, 12A \& B.

RECOGNITION. This species is most similar to Barleria rupicola and B. crassa but is easily separated from them by (i) the corolla limb being markedly zygomorphic with lanceolate adaxial lobes fused in the lower third (vs corolla limb only weakly zygomorphic, adaxial lobes elliptic, not clearly fused at base); (ii) the inflorescence being viscid-glandular throughout (vs glandular hairs absent or sparse and not viscid); (iii) having well-defined spiciform inflorescences with the bracts markedly reduced in comparison to the leaves (inflorescences can be crowded towards stem apices in B. rupicola and B. crassa but the bracts are foliaceous, not reduced); and (iv) having a capitate stigma to $0.3 \mathrm{~mm}$ long (vs linear or clavate, $0.8-2 \mathrm{~mm}$ long).

DISTRIBUTION. Endemic to western Angola (Cuanza Sul Prov.), known only from Mt Namba. Map 7.

SPECIMENS EXAMINED. ANGola. Cuanza Sul, Mt Namba, c. $34 \mathrm{~km}$ W of Cassongue. $\mathrm{N}$ face of mountain above Kanhala village, fl. 12 June 2016, Goyder et al. 8660 (K! holotype, LUBA isotype).

HABITAT \& ECOLOGY. Barleria namba is recorded from open rocky hillslopes subject to grazing, at $\pm 2000 \mathrm{~m}$ elevation.

CONSERVATION STATUS. Barleria namba was first discovered in 2016 and is known only from the type locality of Mt Namba. This mountain has remnant patches of Afromontane forest but some areas have been cleared and are seasonally burned and subject to cattle grazing. The steeper rocky slopes on which this species is found are better protected from some of these impacts and it is likely that these rocky areas support a more open vegetation even in the absence of human disturbance. That said, in view of its extremely small range and the plausible threats from burning and cattle grazing, this species is assessed as Vulnerable VU D2.

ETYMOLOGY. The species epithet "namba" refers to the type locality of Mt Namba.

NOTES. This striking new species appears to be allied to Barleria rupicola and B. crassa as it shares with these 


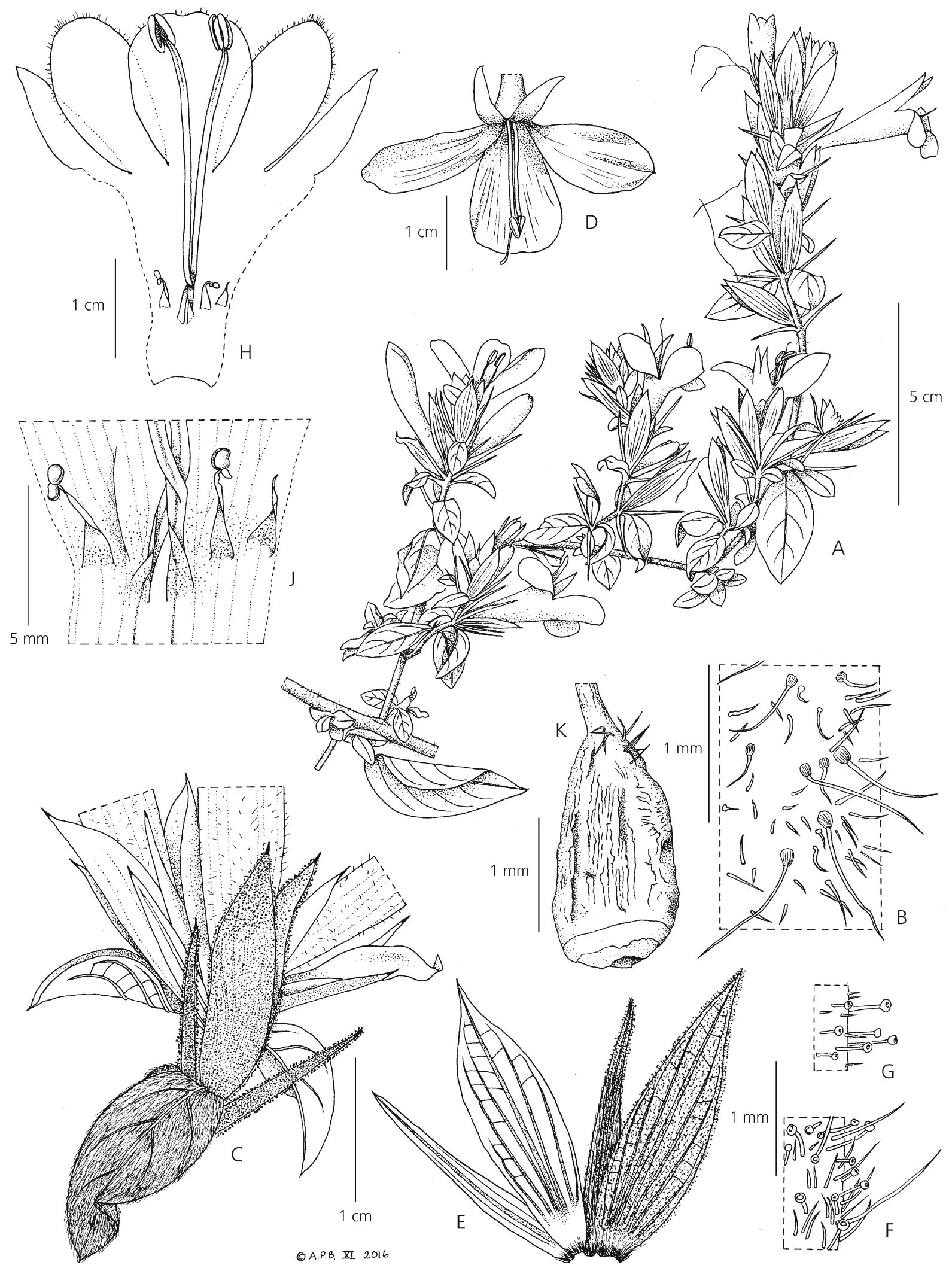

Fig. 11. Barleria namba. A habit; B stem indumentum; C partial inflorescence with corolla bases, induemtum shown only for basal bract, bracteoles and calyx; D flower in face view; E dissected calyx, external suface, posterior lobe to the right, indumentum shown only on one lateral lobe and posterior lobe; $\mathrm{F}$ detail of calyx indumentum, towards apex of posterior lobe; $\mathrm{G}$ detail of calyx indumentum, towards base of posterior lobe; $\mathrm{H}$ dissected corolla with androecium; J detail of staminodes and base of stamens; $\mathrm{K}$ ovary. From Goyder et al. 8660. DRAWN BY ANDREW BROWN. 

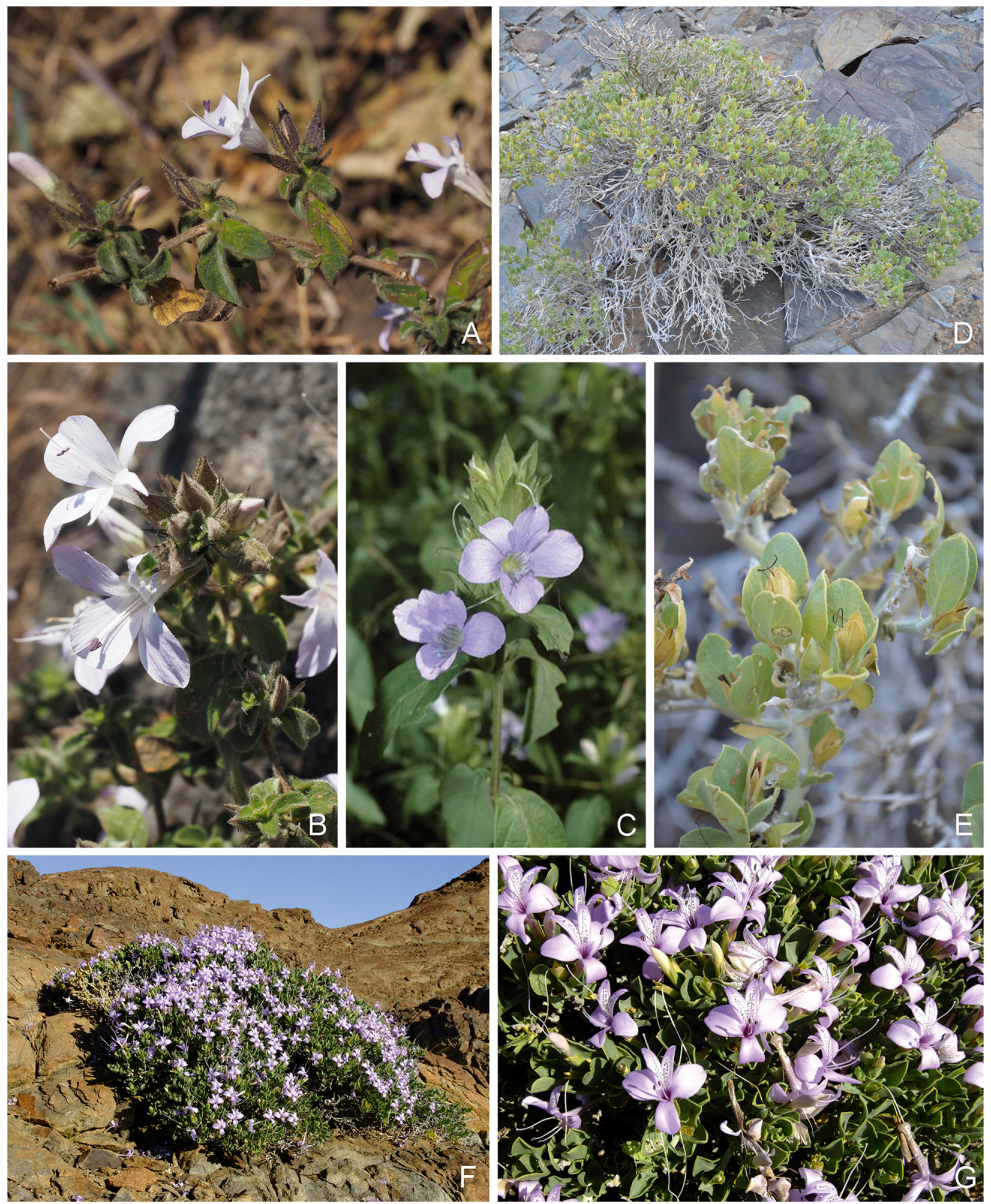

Fig. 12. A \& B Barleria namba, flowering branches. C B. villosa, flowering branch. D - G B. solitaria. D habit showing white stems; $E$ calyces on leafy branches; F habit, flowering plant; G flowers. A \& B Goyder et al. 8660 (Angola); C Cheek 9826 (Cameroon); D \& E Klaassen et al. 2532 (Namibia). PHotos: A \& B D. J. GOYDER; C M. CHEEK; D \& E I. DARBYSHIRE; F \& G H. KOLBERG, NAMIBIA.

species a funnel-shaped throat to the corolla that is longer than the cylindrical base, a " $2+3$ " corolla configuration, linear-lanceolate, conduplicate bracteoles that lack marginal spines or teeth, and straight 
hairs at the insertion point of the style, as well as having a similar ecology. However, it is easily separated from these species by the characters listed in the Recognition section. The corolla form approaches that of B. solitaria (sp. 20 below) although it lacks the purple speckling on the adaxial lobes which are fused for a shorter distance and it has a broader funnelshaped tube.

Within Angola, Barleria namba could also be confused with Barleria villosa on cursory inspection, as they share conspicuously hairy crowded spiciform inflorescences on short lateral branches. However, B. namba differs from $B$. villosa in, amongst many differences, having spinulose bracts and bracteoles (spineless in B. villosa), a very different corolla form, with a " $2+3$ " configuration and partially fused, lanceolate adaxial lobes (" $4+1$ " configuration in $B$. villosa, the adaxial lobes being obovate with rounded or emarginated apices and not being partially fused), the bracteoles and calyces being much more densely glandularpubescent and the fruit apparently being 4-seeded (vs 2-seeded in B. villosa).

20. Barleria solitaria $P$. G. Mey. (Meyer 1967: 513; 1968: 17); Craven (1999: 152); Welman (2003: 94); Klopper et al. (2006: 5); Darbyshire et al. (2012: 766); Klaassen \& Kwembeya (2013: 130). Type: Namibia, Outjo Distr., Escarpment-Abstieg 20 mls von Torrabay, fl. 1 April 1963, Giess et al. 6181 (holotype M! [M0109625]; isotypes MO* [MO-391184], PRE, WAG* [WAG0072609], WIND! [WIND000031806]).

Rounded or cushion-shaped shrub, 20 - $50 \mathrm{~cm}$ tall and up to $100 \mathrm{~cm}$ in diam.; stems \pm markedly angular, at first rather succulent, soon turning woody with white bark, the older stems leafless and appearing jointed due to prominent intrapetiolar line and petiole scars; young stems densely white-puberulous, hairs retrorse or appressed, persistent but less dense on older stems. Leaves with petiole to $4 \mathrm{~mm}$ long; blade variously obovate, oblong-elliptic, ovate-elliptic or orbicular, $1.2-2.3 \times 0.8-1.5 \mathrm{~cm}$ (l:w ratio $1.1-2.1: 1$ ), base cuneate to rounded, margin entire, apex obtuse to rounded or emarginate, minutely apiculate, surfaces puberulous when young but soon glabrescent except for strigose hairs on margin and main veins beneath, often with few broad subsessile glands towards apex beneath; lateral veins 3-4 pairs. Inflorescences of singleflowered axillary cymes but often clustered towards stem apices; bracts foliaceous; peduncle $1.5-4 \mathrm{~mm}$ long; bracteoles linear, oblanceolate or elliptic, 1.8 $5.5 \times 0.3-1.5 \mathrm{~mm}$, blade green or green-brown, midrib pale and prominent, margin entire, apex apiculate. Calyx green or blue- to pink-tinged, with paler prominent palmate venation, tardily turning pale-scarious; anterior lobe elliptic or oblong-elliptic,
$11.5-17 \times 4.5-8 \mathrm{~mm}$, base cuneate, margin subentire or usually with up to 12 teeth formed from vein endings, each with a terminal bristle, apex usually notched, tips mucronulate, strigulose along main veins and with few to more numerous fine to spreading hairs at least towards base; posterior lobe as anterior lobe but 12.5 - 19 mm long, apex acute, mucronate; lateral lobes linear-lanceolate, 8.5 - $13 \mathrm{~mm}$ long. Corolla 32 - $39 \mathrm{~mm}$ long, blue or purple with the adaxial lobes partially white with purple speckling, finely eglandular-pubescent externally mainly on tube and lateral lobes; tube 17.5 - 19 mm long, cylindrical, barely widened towards mouth; limb in " $2+3$ " configuration; abaxial lobe offset by $2-3.5 \mathrm{~mm}$, obovate, $8-$ $12 \times 5.5-10 \mathrm{~mm}$, apex rounded; lateral lobes (obovate-) elliptic or broadly ovate, $9-13.5 \times 6.5-$ $11 \mathrm{~mm}$, apices rounded, emarginate or obtuse; adaxial lobes $10-17 \mathrm{~mm}$ but fused for up to half their length, free portions narrowly oblong-elliptic to ovate, 5.5 $11.5 \times 3-8 \mathrm{~mm}$, apices rounded. Stamens inserted 6.5 - $7 \mathrm{~mm}$ from base of corolla tube; filaments $24-$ $30 \mathrm{~mm}$ long, curved towards apex; anthers $2-3.2 \mathrm{~mm}$ long; lateral staminodes $0.5-3 \mathrm{~mm}$ long, with a broad, pilose basal portion then abruptly narrowed, with or without a slender glabrous apical portion, antherodes absent or well developed, up to $0.9 \mathrm{~mm}$ long. Pistil glabrous; style flattened and rather thick, long-exserted, held well beyond anthers; stigma capitate, to $0.4 \mathrm{~mm}$ long, shallowly bilobed. Old and immature capsules only seen, 4-seeded, $\pm 12 \mathrm{~mm}$ long, glabrous; mature seeds not seen. Fig. 12D - G.

DISTRIBUTION. Endemic to northwestern Namibia (Erongo and Kunene Regions). Map 8.

ADDITIONAL SPECIMENS EXAMINED. NAMIBIA. Omaruru, Brandberg vicinity, SW of the mountain, along the track from Brandberg West Mine, fl. 18 Feb. 1963, Kers 1001 (WIND!); Outjo Distr., 22 miles $\mathrm{E}$ of Torra Bay on road to Welwitschia, fl. 2 April 1963, de Winter Ẽ Hardy 8201 (K!, M!, PRE, WIND!); Outjo Distr., 19 miles SE of Torra Bay, fl. 15 April 1964, Nordenstam 3738 (M!); Bergpass etwa 22 Meilen oestlich Torrabai, fl. \& fr. 17 April 1964, Giess $\mathcal{E}^{2}$ Barnard 8034 (M!, PRE, WIND!); $26 \mathrm{~km} \mathrm{E}$ Brandbergwest Mine zum Brandberg hin, fl. 20 March 1967, Giess 9713 (K!, M!, PRE, WAG*, WIND!); Numas Valley, towards the Ugab R., fl. 28 Feb. 1976, P. Eं D. Craven 26 (WIND!); Ugab R., fl. 6 March 1978, Craven 779 (WIND!); just S of Huab R. $\mathrm{N}$ of Gaias, st. 1 July 1979, Craven 1087 (WIND!); Upper Ugab, fl. 16 Aug. 1979, Müller E Loutit 1199 (WIND!); S of Huab R., N of Gaias, fl. 2 May 1982, Craven 1375 (WIND!); Khorixas Distr., Huab drainage, Farm Krone 721, NNE old farmhouse, fl. 28 March 1996, Ward 13733 (UDW, WIND!); Ugab R. N of Brandberg, fl. 7 Aug. 1999, Wessels WES13 (WIND!); Khorixas Distr., road between Rhino camp 


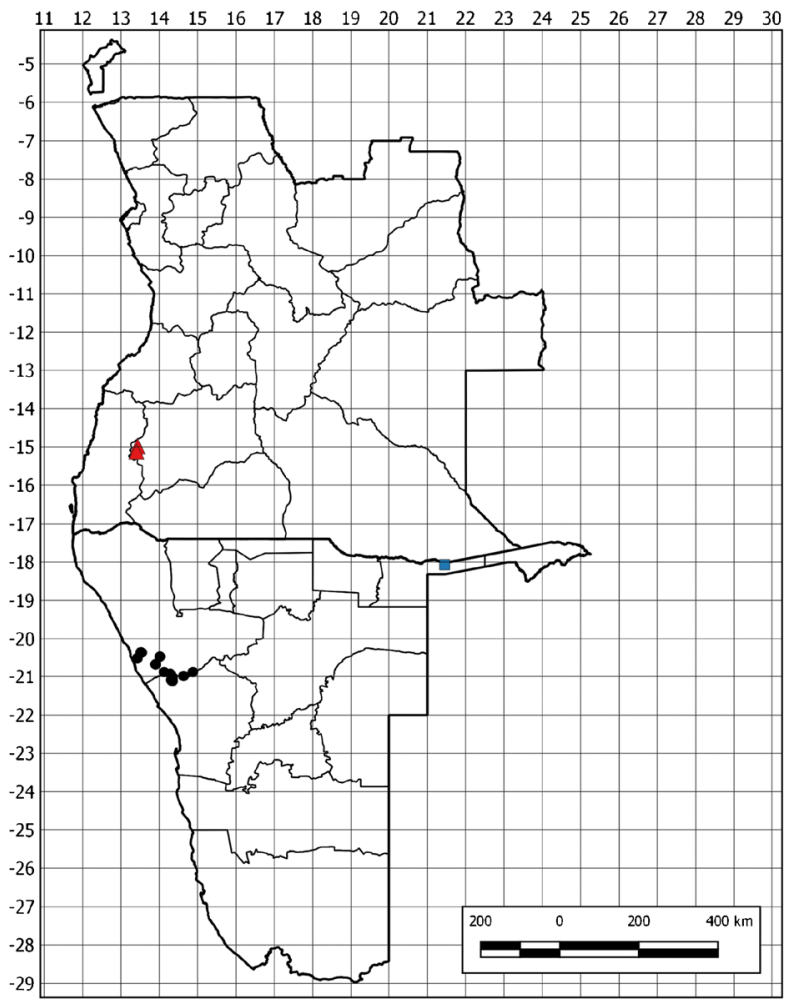

Map 8. Distribution of Barleria solitaria (black circles), $B$. crabbeoides (red triangles) and B. pseudosomalia (blue square - Namibian range only).

and Twyfelfontein, fr. 15 May 2014, Klaassen et al. 2532 (COLO!, K!, WIND!).

HABITAT \& ECOLOGY. Barleria solitaria occurs in very arid, sometimes nearly barren terrain on or at the base of open rocky or boulder-strewn hillslopes and cliffs, and in dry scrub with Commiphora; c. 370 - $550 \mathrm{~m}$ elevation. It can be the most frequent or only shrublet in this harsh environment, although Petalidium variabile (Engl.) C. B. Clarke sensu lato can also be frequent. It is a constituent of the Welwitschia-desert floristic group of Craven (2009) and occurs in the Western-central Escarpment and Inselbergs and Central Desert vegetation types of Mendelsohn et al. (2002).

CONSERVATION STATUS. This is a highly localised species, known from an EOO of $5307 \mathrm{~km}^{2}$ in the hyper-arid mountains adjacent to the Skeleton Coast. It has been recorded as locally common by several collectors and was found to be fairly common by the current authors in a small area near Rhino Camp in the Ugab River drainage. Human threats are limited, although there has been some mining in parts of its range, notably the now inactive Brandberg West Mine which was a large-scale tin mining operation. A more plausible threat is that of increasingly prolonged drought along the Skeleton Coast. However, this species appears to be adapted to periods of drought stress, and displays periodic flowering following infrequent rains. It is currently assessed as of Least Concern - LC but climate change may ultimately threaten this species in the longer term. As such, populations should be carefully monitored. It could potentially qualify as "Rare" (sensu Raimondo et al. 2009) in view of it being a habitat specialist and so likely to have a small AOO but this requires further investigation.

NOTES. This very distinctive species appears to be isolated from other species morphologically within subg. Barleria. The corolla morphology, with both a clearly offset abaxial lobe and a partially fused pair of adaxial lobes, is unusual and more akin to some species in sect. Somalia, such as B. kaessneri S. Moore and allies from central and eastern Africa. It is also odd in having a glabrous pistil and a very long exserted and flattened style.

21. Barleria crabbeoides I. Darbysh. sp. nov. Type: Angola, Huíla Prov., Polygonal Florestal da Humpata, c. $5 \mathrm{~km}$ NE of Humpata, c. $8 \mathrm{~km}$ SW of Lubango, fl. 26 Jan. 2009, Bester 9271 (holotype PRE!; isotype LUBA!).

http:/ /www.ipni.org/urn:lsid:ipni.org:names:77192424-1

Rhizomatous perennial herb, up to $10 \mathrm{~cm}$ tall; rhizome short, somewhat woody and with numerous fleshy adventitious roots; aerial stems with few contracted internodes up to $1.5 \mathrm{~cm}$ long, with dense appressed or ascending pale-buff hairs. Leaves subrosulate with $2-4$ pairs, sessile or petiole to $6 \mathrm{~mm}$ long; blade elliptic or basal-most pairs obovate, largest leaves $4.5-7.2 \times 1.5-$ $2.6 \mathrm{~cm}$ (l:w ratio 2.1 - 3.1:1), base cuneate or attenuate, margin entire, apex acute, obtuse or basalmost leaves rounded; surfaces with numerous pale buff hairs throughout; lateral veins $5-7$ pairs, prominent beneath. Inflorescences of sessile singleflowered cymes, often contracted into a few-flowered head; bracteoles (and bracts within the head) oblongobovate or oblong-elliptic, $16-20 \times 5-6 \mathrm{~mm}$, base attenuate, margin with minute teeth formed by swollen hair bases, apex obtuse or acute, indumentum as leaves. Calyx brown or green-brown in dry state, with darker subparallel primary venation; anterior lobe obovate-elliptic, c. $15-16 \times 6 \mathrm{~mm}$, base attenuate, margin minutely spinulose-dentate, teeth with an apical bristle, apex acute, external surface with numerous subappressed pale buff hairs mainly along the primary veins and margin; posterior lobe as anterior lobe but elliptic, c. $16-17 \times 6.5 \mathrm{~mm}$; lateral lobes linear-lanceolate, c. 9 - $10 \mathrm{~mm}$ long. Corolla blue or purple, drying blue-black, pilose externally; tube cylindrical, 18 - $25 \mathrm{~mm}$ long; limb in " $2+3$ " configuration; abaxial and lateral lobes obovate-elliptic, c. 
$9.5-12 \times 5-8 \mathrm{~mm}$, apices rounded or shallowly emarginate, adaxial lobes somewhat narrower, up to $11.5 \times 6 \mathrm{~mm}$. Stamens inserted in upper half of corolla tube; filaments c. $9 \mathrm{~mm}$ long; anthers held at corolla mouth, $1.8-2.5 \mathrm{~mm}$ long; lateral staminodes c. $4 \mathrm{~mm}$ long, pilose, antherodes c. $0.9 \mathrm{~mm}$ long. Ovary glabrous; style with a few buff-coloured hairs at base and with scattered minute stalked-glands towards apex; stigma clavate, $0.6-0.8 \mathrm{~mm}$ long. Capsule not seen. Fig. 13.

RECOGNITION. This species differs from all known species of Barleria in having the combination of a rhizomatous, subrosulate habit and a capitate or contracted inflorescence with non-spiny bracts and calyces.

DISTRIBUTION. Endemic to southwestern Angola (Huíla Prov.). Map 8.

ADDITIONAL SPECIMEN EXAMINED. ANGOLA. Huíla, Humpata, Lagoa do Ontiti, fl. 15 Dec. 1957, Teixeira 1980 (PRE!).

HABITAT \& ECOLOGY. Barleria crabbeoides has been recorded from open disturbed grassland on welldrained sandy soils and along lake margins; c. 1900 $2050 \mathrm{~m}$ elevation. It occurs, so far as is known, only in the Lubango highlands of the Huila plateau in southwestern Angola. The Huíla plateau is a known centre of plant endemism (Exell \& Gonçalves 1973; Linder 2001; Figueiredo 2008) and the Lubango Highlands are particularly rich in endemic species, with potentially as many as 200 species unique to this area (D. J. Goyder \& F. M. P. Gonçalves, unpubl. data). CONSERVATION STATUS. This species is clearly highly range-restricted and scarce, as it has only been collected twice despite occurring in the well botanised region of the Lubango Highlands. It was recorded as uncommon by B. Teixeira and occasional by S. P. Bester. However, from the very limited information available, it appears to be tolerant of some disturbance. It is currently considered to be Data Deficient - DD, but may well prove to be threatened in view of the high population pressure and resultant degradation and loss of habitat in the Lubango area.

ETYMOLOGY. The species epithet "crabbeoides" refers to the fact that this plant superficially resembles a species of the genus Crabbea in terms of its rosulate habit and capitate inflorescence.

NOTES. This new species is unlikely to be confused with any other species of Barleria because of its unique subrosulate habit. It is unusual for subg. Barleria in that it lacks spines and has the cymes \pm crowded into a terminal head. However, whilst no fruits are available to confirm this sectional placement, it seems very likely to be correct in view of the " $2+3$ " corolla configuration with a cylindrical tube, the presence of antherodes on the lateral staminodes and the clavate stigma, a combination found only in subg. Barleria.
Other non-spiny species are recorded in subg. Barleria, including the recently described B. fissimuroides I. Darbysh. from Mozambique and Zimbabwe (Darbyshire 2015) which has a similar indumentum, corolla form and similarly shaped bracteoles to $B$. crabbeoides but is otherwise very different in, for example, habit, leaf size and shape as it is a shrub to 1 $\mathrm{m}$ tall with well-spaced decussate, long-petiolate leaves $8-11 \times 3-4.7 \mathrm{~cm}$.

Only two specimens of this very distinctive species have been seen to date, and no full floral dissection has been possible, hence the measurements of the corolla and androecium are currently incomplete. However, as this species is so distinct, it seemed wrong to leave it undescribed.

22. Barleria brownii S. Moore (1908: 73); Cavaco (1959: 142); Heine (1963: 420; 1966: 166, fig. 33); Ensermu (2006: 404); Klopper et al. (2006: 3); Sosef (2006: 36); Makholela (2008: 21); Darbyshire (2010b: 358); Darbyshire et al. (2015a: 345). Type: Uganda, Entebbe, fl. Aug. 1905, Brown 313 (lectotype BM! [BM000931100], selected here; isolectotypes $\mathrm{K}$ ! [K000394444, K000394445]).

Barleria longistyla Lindau (1911: 298). Type: D.R. Congo, Kapangapanga, between Beni and Muera, fl. Jan. 1908, Mildbraed 2303 (holotype B十; isotype BR* [BR852437]).

Barleria talbotii S. Moore (in Rendle et al. 1913: 86); Moore (1930: 135). Type: Nigeria, Oban, fl. 13 March 1912, Talbot 1396 (holotype BM! [BM000931083]; isotypes K! [K000394482, K000394483]).

Barleria holstii sensu Makholela (2008: 21) quoad Monteira $\mathcal{E}^{2}$ Murta 217, non Lindau.

Straggling or scandent perennial herb or shrub, $40-600 \mathrm{~cm}$ tall; young stems with short retrorse hairs in two opposite lines, nodes and uppermost internodes sparsely yellowstrigose, soon glabrescent. Leaves on petiole $10-37 \mathrm{~mm}$ long; blade ovate to oblong-elliptic, $6-13 \times 3-6.5 \mathrm{~cm}$ (1:w ratio $1.7-2.8: 1)$, base cuneate, shortly attenuate or rounded, margin entire, apex acuminate or attenuate, glabrous except for occasional appressed hairs on main veins; lateral veins $4-6$ pairs. Inflorescences of $2-9$ flowered, unilateral or partially dichasial cymes arranged in a paniculate or spiciform terminal thyrse $2-12 \mathrm{~cm}$ long; bracts broadly ovate to somewhat obovate, $6-25 \times$ 3.5 - $23 \mathrm{~mm}$; bracteoles variable, linear, oblanceolate, obovate or elliptic, $2-18 \times 0.3-7 \mathrm{~mm}$, margin entire, surface appressed-pubescent or sparsely so. Calyx variable [see note], in our region anterior lobe elliptic to ovate-orbicular, $10.5-19.5 \times 8-17 \mathrm{~mm}$, base obtuse to rounded, margin entire, apex obtuse to rounded or shallowly emarginate, surface appressed-pubescent or sparsely so, with or without few long glandular hairs 


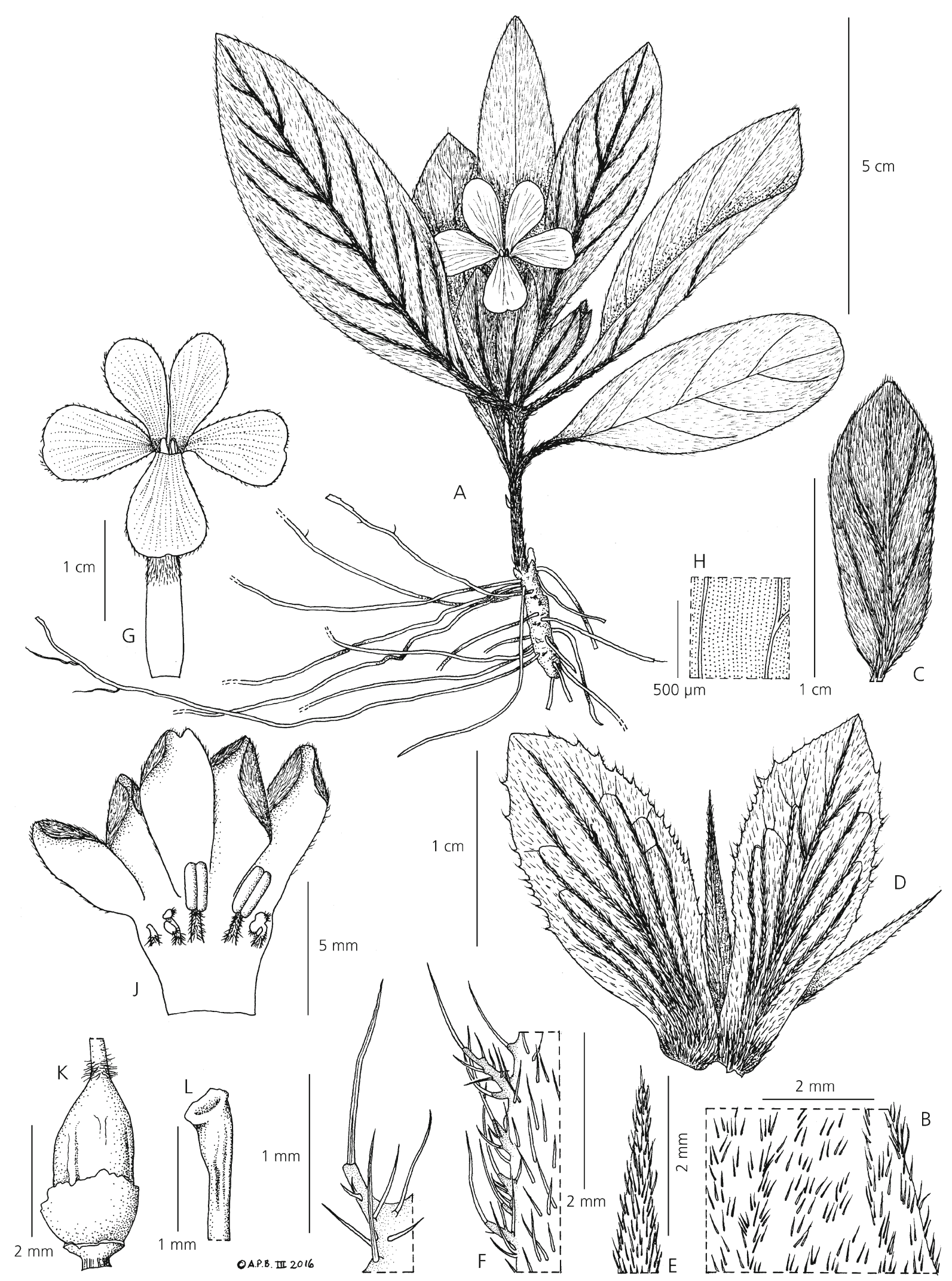

Fig. 13. Barleria crabbeoides. A habit; B detail of leaf indumentum, abaxial surface near margin; C bracteole, abaxial surface; D dissected calyx, external surface, posterior lobe to the left; $E$ indumentum on apical portion of lateral calyx lobe; $F$ details of margin of posterior calyx lobe; G corolla; $\mathrm{H}$ detail of petal surface; J dissected corolla bud showing immature stamens and staminodes; $\mathrm{K}$ ovary and floral disk; L stigma. A - C, G, H \& L Bester 9271, D - F, J \& K Teixeira 1980. DRAWN BY ANDREW BROWN. 
particularly towards apex; posterior lobe $11-24 \times 8-19$ $\mathrm{mm}$, margin often involute, apex obtuse or slightly attenuate; lateral lobes 5 - $7.5 \mathrm{~mm}$ long. Corolla 30 $50 \mathrm{~mm}$ long, white, pinkish-white or blue, throat often tinged pink or purple; glandular-pilose and with fewer eglandular hairs externally; tube 13.5 - $21 \mathrm{~mm}$ long, campanulate above attachment point of stamens; limb in "4+1" configuration, abaxial lobe offset by $2.5-6.5 \mathrm{~mm}$, obovate or elliptic, $16-27 \times 11.5-15 \mathrm{~mm}$, apex rounded; lateral lobes obovate-elliptic to oblong-elliptic, $14.5-26 \times 7.5-12.5 \mathrm{~mm}$, apices rounded or obtuse; adaxial lobes as lateral pair but $4.5-8 \mathrm{~mm}$ wide. Stamens inserted 5.5 - $9 \mathrm{~mm}$ from base of corolla tube, long exserted; filaments $35-65 \mathrm{~mm}$ long; anthers $2.5-4 \mathrm{~mm}$ long; lateral staminodes $1.5-9.5 \mathrm{~mm}$ long, with minute stalked glands and occasional hairs towards base or throughout, antherodes well developed, $1.2-2 \mathrm{~mm}$ long. Pistil glabrous; stigma long exserted, clavate, 0.4 $0.9 \mathrm{~mm}$ long. Capsule 2-seeded, 12.5 - $14.5 \mathrm{~mm}$ long, glabrous; seeds $\pm 6 \times 5 \mathrm{~mm}$.

DISTRIBUtION. Angola (Cabinda and Lunda Norte Provs.); widespread in the Guineo-Congolian forests of Ghana, Nigeria, Cameroon, Central African Republic, Equatorial Guinea, Gabon, Congo (Brazzaville), D. R. Congo, South Sudan, Ethiopia, Uganda and Tanzania. Map 7.

SPECIMENS EXAMINED. ANGOLA. Cabinda, Buco Zau, fl. 27 July 1916, Gossweiler 6530 (BM!); Dundo, prox. R. Luachimo, fl. June 1948, Gossweiler 14206 (K!); Cabinda, na estrada de Buco Zau - Belize, fl. 9 June 1960, Monteiro E Murta 217 (LUBA!, PRE!).

HABITAT \& ECOLOGY. In Angola, Barleria brownii has been recorded in riverine and lowland forest, often in clearings, margins or areas of secondary regrowth; 50 $700 \mathrm{~m}$ elevation. It is a species of the Guineo-Congolian Regional Centre of Endemism (White 1983).

CONSERVATION STATUS. This species is widespread in the Guineo-Congolian forests with an EOO of over 3.9 million $\mathrm{km}^{2}$ and can be locally common including in disturbed habitat; it was assessed as of Least Concern (LC) by Darbyshire (2010b). In Angola, it is at the southwestern edge of its range and is restricted to the Maiombe forests of Cabinda and the forests of the north-flowing rivers (Congo tributaries) of Lunda Norte. It was recorded as very frequent by Monteiro \& Murta at Buco Zau in Cabinda in 1960. However, forest extent has declined in this region over recent decades, with extensive mining activity being clearly visible on Google Earth imagery. Much of the riverine forest around Dundo in Lunda Norte has also been lost due to extensive alluvial diamond mining along the Luachimo River and its tributaries and expansion of Dundo town (Huntley 2011; Cheek et al. 2015). Therefore, this species is likely to be nationally threatened in Angola under IUCN criterion B.
NOTES. The Angolan specimens seen have broadly elliptic to ovate-orbicular outer calyx lobes which match the form described from Nigeria as Barleria talbotii S. Moore (Rendle et al. 1913). However, as noted in Darbyshire (2010b), intermediates between this form and the narrower oblong-elliptic outer calyx lobes of typical B. brownii are recorded in West and Central Africa. As there is no clear geographic trend, talbotii would at most warrant varietal status.

In Darbyshire (2010b), the BM sheet of Brown 313 was listed as the holotype and the $\mathrm{K}$ duplicate (2 sheets) as an isotype. However, both duplicates were mentioned in the protologue, hence a lectotypification is required - the $\mathrm{BM}$ sheet is selected here as it is the more complete specimen.

23. Barleria villosa S. Moore (1880: 267); Clarke (1899: 164); Hiern (1900: 817); Moore (1930: 135); Klopper et al. (2006: 5); Makholela (2008: 22). Type: Angola, Pungo Andongo, Golungo Alto, "Queta orientalis", fl. June 1856, Welwitsch 5071 (lectotype BM! [BM000931106], selected here; isolectotypes K! [K000394497], LISU! [LISU223415]). Additional original syntype: Angola, "Dist. Golungo Alto, edit. Sobati de Quilombo", fl. July 1856, Welwitsch 5070 (BM! [BM001252127], K! [K000394496], LISU! [LISU223416]).

Perennial herb or subshurb, erect or scrambling, up to 2 $\mathrm{m}$ tall; stems pubescent to villose with pale-buff or grey-brown hairs of variable length, ascending or subspreading, sometimes most dense on two opposite sides. Leaves on petiole $7-43 \mathrm{~mm}$ long or uppermost leaves subsessile; blade ovate or ovate-elliptic, $3-9 \times$ $1.5-4 \mathrm{~cm}$, base attenuate or that of uppermost leaves rounded, margin entire, apex attenuate, acuminate or acute, surfaces pubescent, most dense beneath, hairs along the main veins beneath longer and more appressed, hairs mainly pale grey-buff but can be glossy brown especially when young; lateral veins $5-7$ pairs. Inflorescences crowded terminal spikes $3-9(-19)$ $\mathrm{cm}$ long, comprising a series of 1 - 3-flowered subsessile cymes, flowers sometimes held mainly on one side of spike, lowermost cymes sometimes becoming less crowded; bracts foliaceous, elliptic, typically $10-22 \times 4-9 \mathrm{~mm}$ at midpoint of spike, densely pubescent with buff to brown hairs, sometimes appearing silky; bracteoles held erect, oblanceolate to spathulate, $7-15 \times 1-2.5 \mathrm{~mm}$, apex acute to obtuse, margin entire, indumentum as in bracts, with or without interspersed short glandular hairs. Calyx drying green-brown, anterior lobe lanceolate or narrowly elliptic, $12-17 \times 4.5-6 \mathrm{~mm}$, base cuneate, margin entire, apex deeply bifid for $3-6.5 \mathrm{~mm}$ with slender lobes, surface densely pubescent with silky ascending pale buff to yellow-buff hairs, sometimes 
with few interspersed short glandular hairs mainly towards base; posterior lobe like anterior lobe but ovate-lanceolate to elliptic-lanceolate, apex acute; lateral lobes linear-lanceolate, 6 - 10.5 (- $15.5 \mathrm{~mm})$ long, usually with few glandular hairs towards apex. Corolla blue or lilac, $35-42 \mathrm{~mm}$ long, pubescent to pilose externally with mixed glandular and eglandular hairs; tube 15 - $23 \mathrm{~mm}$ long, basal cylindrical portion 8 - $11 \mathrm{~mm}$ long, upper portion markedly funnelshaped; limb in " $4+1$ " configuration, abaxial lobe offset by $5-7 \mathrm{~mm}$, (oblong-) obovate, $12.5-14 \times 6$ $-9 \mathrm{~mm}$, apex rounded or shallowly emarginate; lateral lobes as abaxial lobe but $9.5-13.5 \times 5.5-7.5 \mathrm{~mm}$; adaxial lobes $9-12.5 \times 3.5-5.5 \mathrm{~mm}$. Stamens inserted $8-10.5 \mathrm{~mm}$ from base of corolla; filaments 19 $27 \mathrm{~mm}$ long; anthers 2.5 - $3 \mathrm{~mm}$ long; lateral staminodes $1-2.2 \mathrm{~mm}$ long, pubescent, with \pm well developed antherodes $0.6-1.1 \mathrm{~mm}$ long. Pistil glabrous; stigma clavate or subcapitate, $(0.35-) 0.5$ $0.9 \mathrm{~mm}$ long. Capsule 2-seeded, $\pm 12.5 \mathrm{~mm}$ long, glabrous; only immature seeds seen. Fig. 12C.

DIStRIBUtion. Angola (Cabinda, Cuanza Norte, Cuanza Sul, Malange and Uíge Provs.); widespread in West Africa: Guinée, Ghana, Togo, Nigeria, Cameroon, Central African Republic, D. R. Congo. Map 5.

SPECIMENS EXAMINED. ANGOLA. Near Malange, fl., without date, Gossweiler 1078 (K!); Camondoi, fl. 21 June 1911, Gossweiler 4993 (BM!); Nkanda Plateau, fl. 1921, Dawe 112 (K!); Cuanza Sul, Amboim, Assango, fl. \& fr. 10 July 1937, Exell E Mondonça 3123 (BM!); Libolo Distr., fl. Aug. 1937, Boss in TRV 36662 (PRE!); Cuanza Norte, Dembos, Quibaxe, arredores da Missão Católica de Quibaxe, fl. 3 July 1960, Barbosa $\mathcal{E}$ Henriques 9181 (BM!, LUBA!); Cuanza Norte, entre Salazar e Lucala, fl. 26 Aug. 1967, da Silva 2142 (LISC!); Uíge, near village Camancoco, fl. 19 July 2015, Lautenschläger 53 (DR*).

HABITAT \& ECOLOGY. Barleria villosa is recorded from shaded habitats including riverine forest and thicket, particularly along margins and in adjacent grassland, in dry forest and in secondary woodland; c. $200-900 \mathrm{~m}$ elevation. It is a species of the Guineo-Congolian Regional Centre of Endemism (White 1983).

CONSERVATION STATUS. Barleria villosa is a widespread species of the Guineo-Congolian region; whilst the EOO has not been fully delimited it is estimated to be in excess of 3 million $\mathrm{km}^{2}$. Habitat loss will have resulted in some localised population declines, but this species is not considered to be globally threatened, and is assessed as of Least Concern LC.

NOTES. Barleria villosa falls within the B. ventricosa Nees complex and, together with the closely related $B$. opaca Nees, represents the West African element of this challenging group. It could easily be sunk into the
B. ventricosa aggregate species (see Darbyshire 2010b) but we are reluctant to do so until detailed molecular work is carried out on this group. Although rather variable, $B$. villosa is recognised by consistently having a crowded spiciform terminal inflorescence, a rather dense inflorescence indumentum, relatively long and erect bracteoles and a deeply bifid anterior calyx lobe. In B. ventricosa s.l., this approaches the form from northern Uganda, northeast D.R. Congo and South Sudan sometimes separated as B. vixdentata C. B. Clarke (see Darbyshire 2010b). However, B. villosa has a more dense indumentum. Barleria vix-dentata could potentially represent an intermediate form between $B$. villosa in the West and B. ventricosa in the East, but molecular work would be needed to investigate this hypothesis. The Angolan populations of $B$. villosa can also superficially resemble the form of $B$. ventricosa sometimes separated as B. keniensis Mildbr., widespread in East Africa, which can have a densely hairy, congested compound inflorescence, but it differs from $B$. villosa in having an entire or minutely notched apex to the anterior calyx lobe and in having shorter, often minute, bracteoles (Darbyshire 2010b).

Some populations of Barleria villosa from West Africa, notably in Nigeria and West Cameroon (e.g. Coombe 61; Cheek 9826, both K!), are larger in all their floral parts, with bracteoles over $20 \times 3.5 \mathrm{~mm}$, outer calyx lobes over $20 \mathrm{~mm}$ long and often proportionally broader, and corollas over $45 \mathrm{~mm}$ long. Heine (1963) suggests that the calyces of this species are rapidly accrescent after anthesis and that the Welwitsch type specimens from Angola are very young and so have much smaller calyx lobes than usual. However, examination of further material from Angola and adjacent D. R. Congo indicates that this is not true, but rather the specimens in the southern part of the range of $B$. villosa have consistently smaller floral parts even after anthesis. Small-flowered forms of $B$. villosa also occur in other parts of its range, for example in the Central African Republic. The description above covers only the variation recorded in Angola and adjacent D. R. Congo.

The BM sheet of Welwitsch 5071 is chosen as the lectotype of Barleria villosa as it is an informative specimen, annotated by Spencer Moore.

24. Barleria pseudosomalia I. Darbysh. (Darbyshire 2010b: 377); Darbyshire et al. (2012: 765, Fig. 5); Klaassen \& Kwembeya (2013: 130). Type: Tanzania, Mpwapwa Distr., 2 - 3 miles on Kibakwe to Motta track, fr. 10 April 1988, Bidgood, Mwasumbi E Vollesen 1001 (holotype $\mathrm{K}$ sheet 1! [K000779572]; isotypes C, CAS, DSM!, EA! [EA000003208], K sheet 2! [K000779571]).

Barleria galpinii sensu auctt., non Lindau: Meyer (1968: 14); Craven (1999: 152). 
Subshrub or prostrate perennial herb, to $50 \mathrm{~cm}$ tall; stems soon woody with pale grey or sandy-coloured bark, young stems with stiff appressed buff-yellow hairs and sometimes with scattered short retrorse hairs, soon glabrescent. Leaves sessile or petiole to $6 \mathrm{~mm}$ long; blade (ovate-) elliptic to narrowly so, $5.5-10.5 \times 1.9-3.8 \mathrm{~cm}$ (l:w ratio 2.6 - 2.9 (- 3.6):1), base long-attenuate, apex acuminate, surfaces with coarse appressed or ascending hairs along principal veins and margin and scattered above, sparse on mature leaves; lateral veins $4-6$ pairs. Inflorescences axillary, flowers solitary; bracts foliaceous; bracteoles often caducous, linear or narrowly elliptic-lanceolate, $2.5-10 \times 0.2-1.5$ $\mathrm{mm}$, ascending; pedicels $4-11 \mathrm{~mm}$ long. Calyx scarious in fruit; anterior lobe broadly ovate, $16-23 \mathrm{~mm}$ long and wide, base (sub)cordate, margin entire, apex truncate or emarginate, margin ciliate with appressed or ascending hairs, elsewhere glabrous or principal veins with few hairs; posterior lobe 20.5 - $29 \mathrm{~mm}$ long, base rounded or shallowly cordate, apex attenuate; lateral lobes linear-lanceolate, 5.5 - $10 \mathrm{~mm}$ long. Corolla 42 $48 \mathrm{~mm}$ long, (pale) blue with white throat, sparsely glandular-pilose externally; tube 19 - $25 \mathrm{~mm}$ long, broadly funnel-shaped above attachment point of stamens, c. 12.5 - $14.5 \mathrm{~mm}$ wide at mouth; limb in " $4+1$ " configuration, abaxial lobe offset by $\pm 9-11.5 \mathrm{~mm}$, obovate, $19-22.5 \times 12-14.5 \mathrm{~mm}$, apex emarginate; lateral lobes obovate, $13.5-15 \times 11-13 \mathrm{~mm}$, apices emarginate; adaxial lobes as lateral pair but $\pm 9 \mathrm{~mm}$ wide. Stamens inserted $7.5-8 \mathrm{~mm}$ from base of corolla tube; filaments $\pm 22-24 \mathrm{~mm}$ long; anthers $3.5-4.5 \mathrm{~mm}$ long; lateral staminodes $2-2.5 \mathrm{~mm}$ long, pilose, antherodes 1 $1.2 \mathrm{~mm}$ long. Pistil glabrous; stigma subcapitate, 0.5 $0.7 \mathrm{~mm}$ long. Capsule 2-seeded, 13 - $14.5 \mathrm{~mm}$ long, glabrous; seeds $7.5-8.5 \times 7-8 \mathrm{~mm}$.

DISTRIBUTION. Northeastern Namibia (Kavango East Region); Tanzania. Map 8.

SPECIMENS EXAMINED. NAMIBIA. Okavango Native Territory, Andara Mission Station, fl. 14 Jan. 1956, de Winter Eं Wiss 4250 (K!, M!, PRE, WIND!).

HABITAT \& ECOLOGY. In Namibia, Barleria pseudosomalia has been recorded from the shade of moist dense bushland on sandy soil, at c. $1000 \mathrm{~m}$ [elevation not recorded on specimen]. The single known locality is within the North-eastern Kalahari Woodland vegetation type of Mendelsohn et al. (2002). In Tanzania, it is recorded from dry woodland and scrub with Brachystegia microphylla Harms at 1200 - 1250 m elevation.
CONSERVATION STATUS. This species is assessed as Endangered - EN B2ab(iii) on the IUCN Red List (Luke et al. 2015). It has only been found once in Namibia and in view of the high levels of disturbance along the Okavango River, it must be considered highly threatened there and there is an urgent need to assess its current status in Namibia.

NOTES. The remarkable disjunction in the range of this species is discussed by Darbyshire et al. (2012: 765, Fig. 5); where this species is illustrated. With its large, conspicuous flowers it is unlikely to be overlooked and so is likely to be truly rare, but populations may be found in Zambia in the future.

Barleria subg. Prionitis (Nees) C. B. Clarke (1884: 482); Clarke (1899: 141), pro parte excl. B. triacantha.

Barleria sect. Prionitis Nees (1847: 237), pro parte; Obermeyer (1933: 129); Balkwill \& Balkwill (1997: 561); Darbyshire (2010b: 415; 2015: 109). Prionitis (Nees) Oerst. (Oersted 1854: 137).

Axillary spines present, comprising spinose $2-4$ (-8)rayed modified shoots, or absent. Indumentum of simple hairs, or plants glabrous. Leaves often yellowish-green or glaucous; leaf base decurrent into petiole. Inflorescences single-flowered or dichasial cymes, either axillary, then bracts foliaceous, or compounded into terminal synflorescences, then bracts modified. Corolla (in our region) yellow, orange, apricot or ochre-coloured, rarely white or violettinged; limb subregular or usually in " $4+1$ " configuration. Stamens 2 perfected; staminodes 2 or 3, lateral pair with antherodes present, adaxial staminode, if present, much reduced and antherode absent. Pistil with stigma linear or clavate, apex entire or minutely bilobed. Capsule drying (pale) brown, laterally compressed, with a pronounced solid apical beak; lateral walls remaining attached to flanks at dehiscence, septum woody throughout; seeds 2 , ovate-discoid, with dense straight buff to golden hygroscopic hairs.

NOTE. This section comprises c. 45 species and is most diverse in the dry woodlands, bushlands and semi-deserts of Northeast and East Africa and Madagascar, typically favouring habitats that are not fire-prone.

\section{Key to Barleria sect. Prionitis in Angola and Namibia}

1. Plants not spiny; outer calyx lobes oblong-lanceolate, oblong-elliptic or somewhat obovate, at least the anterior

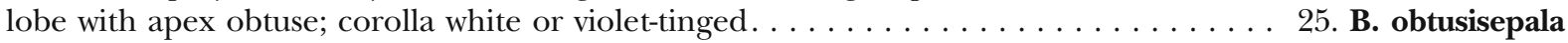
Plants with rayed axillary spines and/or spine-tipped bracteoles; outer calyx lobes ovate or lanceolate, apices attenuate, acute or abruptly narrowed into an apiculum, anterior lobe sometimes bifid or notched at apex; corolla yellow, orange, apricot, ochre-coloured or rarely white $\ldots \ldots \ldots \ldots$ 
2. Outer calyx lobes puberulous, broadly ovate, l:w ratio $1.3-1.6$ : 1; inflorescence a short strobilate terminal spike, the bracts (excluding basal-most pair) ovate, highly modified from the narrowly elliptic or oblanceolate

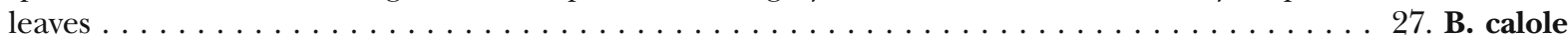
Outer calyx lobes variously glabrous, strigose or with few short glandular hairs but never puberulous, ovate or lanceolate, l:w ratio $\geq 1.9$ : 1 ; if inflorescence a terminal spike then bracts not ovate. . . . . . . . 3

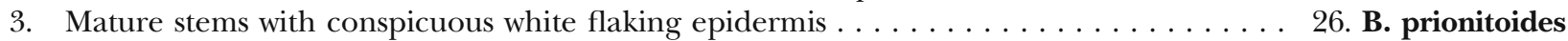

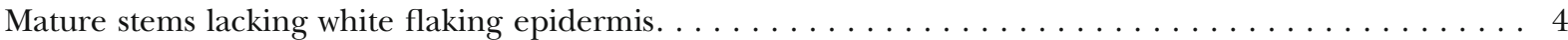

4. Inflorescence a well-defined terminal spike or head with obovate or spathulate bracts clearly differentiated from the leaves; bracts often with bulbous-based hairs along margins . . . . . . . . . . 29. B. senensis Inflorescences axillary or in a loosely defined leafy terminal spike, bracts foliaceous or only gradually becoming differentiated distally, not obovate or spathulate, lacking bulbous-based marginal hairs. . . . . . . . . 5

5. Perennial herb or subshrub without woody rootstock, branches often rooting at lower nodes; outer calyx lobes

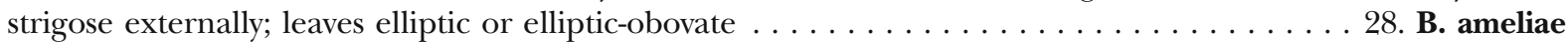
Compact shrublet or suffrutex with woody rootstock, branches not rooting at lower nodes; outer calyx lobes glabrous or at most sparsely strigulose externally; leaves narrowly oblong, oblong-elliptic, oblong-lanceolate or

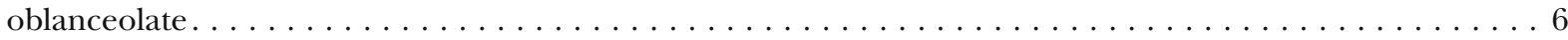

6. Leaves and especially bracts with \pm numerous broad sessile glands towards base beneath; young foliage with \pm numerous appressed short white hairs throughout resulting in a glaucous appearance; corolla glabrous

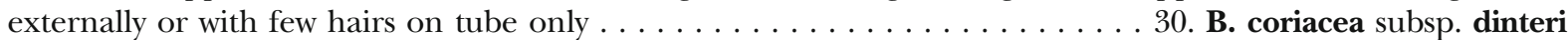
Leaves and bracts with broad sessile glands absent or very few; young foliage glabrous or with strigose hairs restricted to margin and midrib, bright green; corolla pubescent externally . . . . . . . . . . . 7

7. Corolla in marked " $4+1$ " configuration, abaxial lobe offset by $6.5-9.5 \mathrm{~mm}$ and markedly smaller than lateral lobes, $8-13.5 \times 3-6 \mathrm{~mm}$; outer calyx lobes lanceolate, $3.5-6 \mathrm{~mm}$ wide, without involute

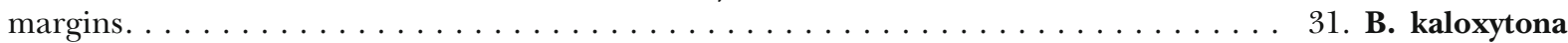
Corolla subregular, abaxial lobe barely offset from the other lobes and similar in size, $14.5-15.5 \times 9.5-10.5 \mathrm{~mm}$; outer calyx lobes more broadly lanceolate, $6-9 \mathrm{~mm}$ wide, with involute margins . . . . . . . 32. B. fernandae

25. Barleria obtusisepala C. B. Clarke (1899: 158); Hiern (1900: 816); Benoist (1950: 16); Klopper et al. (2006: 4); Makholela (2008: 22). Type: Angola, "inter Mangue et Calunda”, fl. March 1857, Welwitsch 5162 (lectotype BM! [BM000931114], selected here; isolectotypes K! [K000394516], LISU! [LISU223400]). Barleria sp. nov. aff. B. salicifoliae sensu Moore (1880: 270), pro parte quoad Welwitsch 5162.

Rhizomatous suffruticose herb, 1 - few erect stems from a woody rootstock, $20-90 \mathrm{~cm}$ tall, unbranched or with few slender erect or ascending lateral branches; stems 4 angular, convex, glabrous or uppermost internodes inconspicuously puberulent on two opposite sides, nodal line strigulose. Axillary spines absent. Leaves sessile or petiole to $5 \mathrm{~mm}$ long; blade held \pm erect, sometimes caducous such that lower nodes often leafless, rather stiff, (grey-) green above, yellow-green beneath, narrowly oblong-elliptic, oblong-lanceolate or somewhat oblanceolate, $8.5-12 \times$ $1.2-3.7 \mathrm{~cm}$ (l:w ratio $3.2-6.9: 1$ ), base cuneate, attenuate or abruptly narrowed, margin entire, sometimes revolute, apex acute or obtuse, glabrous or margins sparsely strigose, lowermost leaf pairs more elliptic; lateral veins $4-6$ pairs, prominent beneath. Inflorescences terminal on main and lateral branches, capitate or spiciform, up to $7.5 \mathrm{~cm}$ long, each cymule single-flowered, subsessile; bracts imbricate, green, variously ovate, lanceolate, elliptic or somewhat obovate, $18-30 \times 8-19 \mathrm{~mm}$, apex acute or obtuse, apiculate, margins strigose; bracteoles held erect, equal in length to or slightly shorter than calyx, green, lanceolate or narrowly oblong-elliptic to somewhat oblanceolate, $18-25$ $\times 4.5-7 \mathrm{~mm}$, margin entire, apex acute, apiculate, surfaces glabrous or puberulent, margins strigose. Calyx (grey-) green or brownish, anterior and posterior lobes subequal or the latter somewhat narrower, oblong-lanceolate to oblong-elliptic or somewhat obovate, $14-27 \times 7.5-10.5$ $\mathrm{mm}$, margin entire, apex obtuse or posterior lobe more acute, apiculate, external surface glabrous or eglandularand glandular-puberulous, margin strigulose; lateral lobes lanceolate-attenuate, 12 - $20 \mathrm{~mm}$ long, glandularpuberulous towards apex. Corolla white or faintly tinged violet, eglandular-pubescent externally; tube cylindrical, c. 17.5 - 23 mm long; limb configuration unknown; lobes obovate, abaxial and lateral lobes c. $11-18 \times 8-11 \mathrm{~mm}$, apices obtuse or rounded. Stamens inserted c. $8.5 \mathrm{~mm}$ from base of corolla tube; mature filaments and anthers not seen; lateral staminodes $0.8 \mathrm{~mm}$ long, antherodes well developed, 0.6 - $0.7 \mathrm{~mm}$ long. Ovary glabrous; stigma clavate, $0.8 \mathrm{~mm}$ long. Capsule only seen in immature state, $14 \mathrm{~mm}$ long, glabrous; immature seeds only seen. Fig. 14J $-\mathrm{P}$.

DISTRIBUTION. Endemic to western Angola (Benguela, Bié, Huambo and Malange Provs.). Map 9.

ADDITIONAL SPECIMENS EXAMINED. ANGOLA. Benguela, Bailundo Distr., fl., without date, Wellman s.n. (K!); 


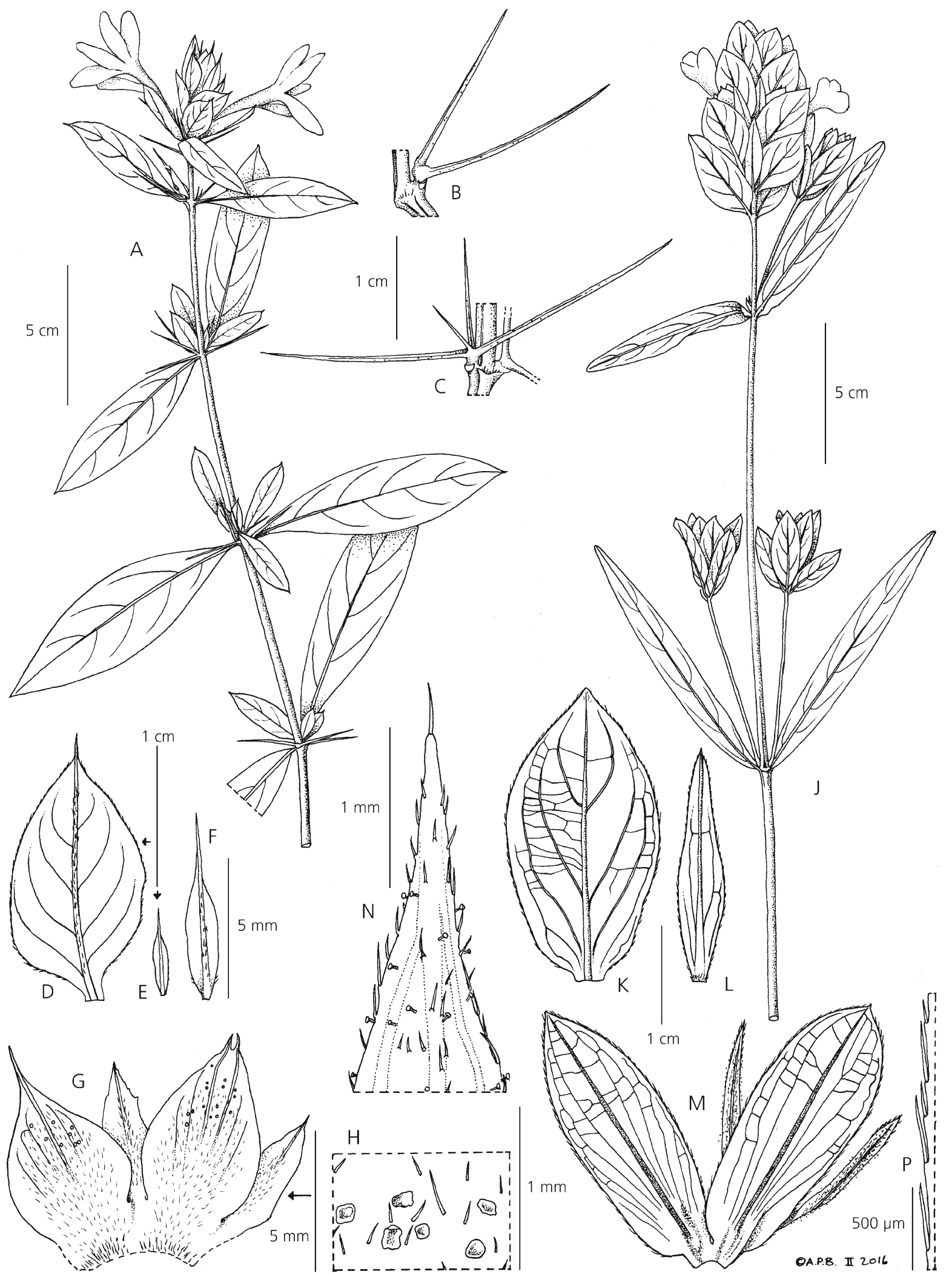

Fig. 14. A - H Barleria calole. A habit; B 2-armed axillary spine; C 4-armed axillary spine; D bract, external surface; E bracteole at same scale as $D$; $F$ bracteole magnified, external surface; $G$ dissected calyx, external surface; $H$ detail of hairs and glands on calyx surface. J - P B. obtusisepala. J habit; K bract, external surface; L bracteole, external surface; M dissected calyx, external surface; N apex of lateral calyx lobe showing indumentum; P marginal hairs of anterior calyx lobe. A - H from Gossweiler 8268; J, K, M - P from Faulkner A.404, L from Welwitsch 5162. DRAWN BY ANDREW BROWN. 


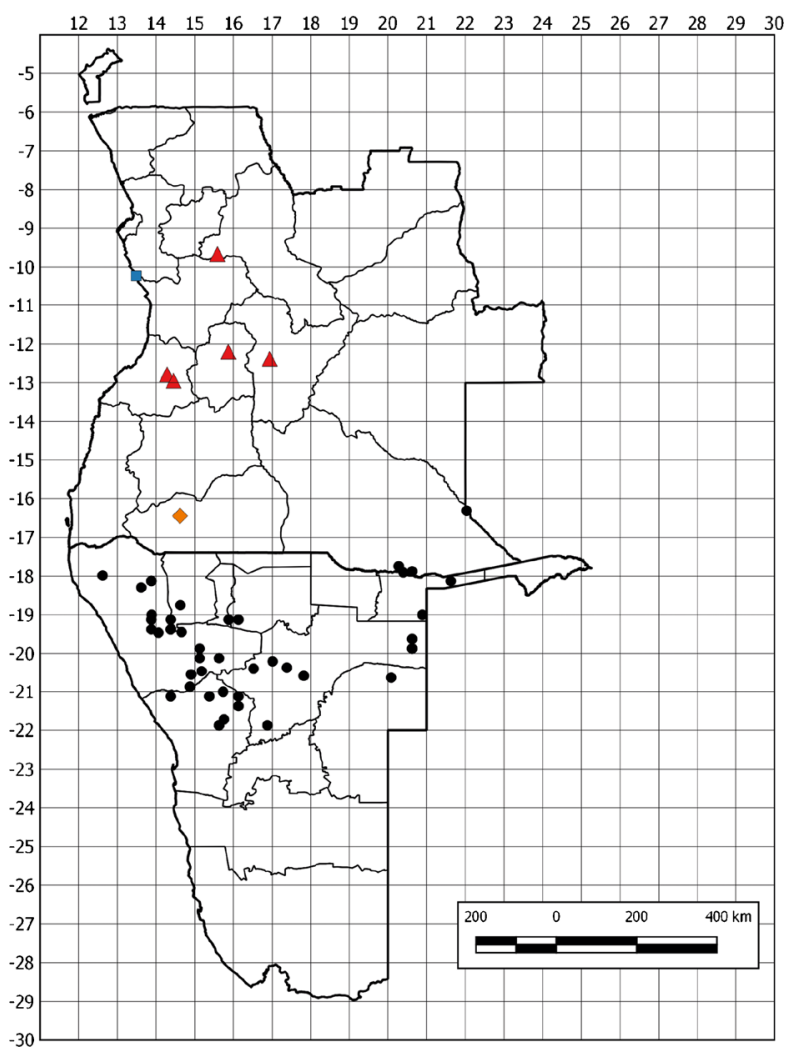

Map 9. Distribution of Barleria obtusisepala (red triangles), $B$. calole (blue square), $B$. senensis (black circles - Angolan and Namibian range only) and $B$. fernandae (orange diamond).

Benguela, Quipeio, fl. \& fr. 11 May 1937, Exell E̋ Mendonça 1862 (BM!); Benguela, Cubal, Capacca (Membassõco), 218 km inland, fl. 1940 - 1941 [date not on label], Faulkner A.404 (BM!, K!, PRE!); Bié, in bud, without date, ?Gossweiler s.n. [collector not recorded on sheet] (BM!).

HABITAT \& ECOLOGY. Barleria obtusisepala occurs in grasslands, miombo woodlands, and mosaics of xerophytic bushland, thickets or "light forest"; 1050 - 1550 $m$ elevation.

CONSERVATION STATUS. Although currently known from only the five specimens cited, this species has a fairly large range, with an EOO of $49,930 \mathrm{~km}^{2}$. This is well beyond the $20,000 \mathrm{~km}^{2}$ EOO range limit for threatened species under IUCN criterion B1 (IUCN 2012). Faulkner recorded that it "seems fairly common" in the Capacca area, but no other data on abundance are available and the information on habitat requirements is also very limited. With this in mind, this species is currently considered to be Data Deficient - DD but is considered likely to prove to be of Least Concern once further information on this species becomes available.

NOTES. There is very little material available of this distinctive species, such that the description remains incomplete particularly with regard to the flowers. The five specimens seen show considerable variation in some characters and it is possible that more than one taxon is involved, although we believe that they will prove to be variants of a single entity. Faulkner A.404 is particularly striking in having an elongate, spiciform inflorescence with elliptic or somewhat obovate bracts and with very large calyces. By comparison, the type specimen has a capitate inflorescence with ovate or lanceolate bracts and smaller calyces. However, the young inflorescences on the lateral branches of the Faulkner specimen look very similar to those on the type. Further, Exell $\mathcal{E}^{\circ}$ Mendonça 1862 shares the capitate inflorescence of the type but has bracts and calyces similar to the Faulkner specimen. Faulkner's plants are large (to $90 \mathrm{~cm}$ tall, vs $20-50 \mathrm{~cm}$ in other material seen) and we suspect that the more elongate inflorescence is a result of this more luxuriant growth. There is also some variation in calyx indumentum: in Wellman s.n. and ?Gossweiler s.n. the outer lobes are puberulent, some of the hairs gland-tipped, whilst in Faulkner A.404 they are glabrous externally. However, Exell $\mathcal{E}^{\circ}$ Mendonça 1862 is again somewhat intermediate, the calyces having a sparsely puberulent indumentum. It is possible that the calyx hairs are caducous following anthesis, as the Wellman and ?Gossweiler sheets bear only immature flowers.

There has been some past confusion over the infrageneric placement of this species. Moore (1880) originally considered it to be close to Barleria salicifolia which falls in sect. Stellatohirta, but this is clearly incorrect as it lacks stellate hairs and has beaked fruits. Clarke (1899) placed it within his "Eubarleria: Glabratae" which mainly consisted of species from the current sect. Somalia, which is where Balkwill \& Balkwill (1997) placed B. obtusisepala. Indeed, the suffruticose habit, lack of spines, rather large calyces and white flowers do give this species a superficial resemblance to some groups of species within sect. Somalia. However, the presence of antherodes on the lateral staminodes rules this section out and the immature fruits seen on Exell $\mathcal{E}^{\circ}$ Mendonça 1862, which are gradually narrowed to a conical beak, have a woody upper portion of the septum and have seeds with straight non-woolly hygroscopic hairs, confirming that this species belongs to sect. Prionitis.

26. Barleria prionitoides Engl. (Engler 1888: 262); Obermeyer (1933: 141); Meyer (1957: 384; 1968: 16); Welman (2003: 94); Klopper et al. (2006: 4); Darbyshire et al. (2012: 766); Klaassen \& Kwembeya (2013: 130). 三 Barleria prionitis L. subsp. prionitoides (Engl.) Brummit \& J. R. I. Wood (in Wood et al. 1983: 442); Craven (1999: 152); Klopper et al. (2006: 4); Makholela (2008: 22). Type: Namibia, Karribib [Karibib], fl. \& fr. May 1886, Marloth 1430 (lectotype 
B sheet 1! [labelled with "Kew Negative 13383"], selected here; isolectotypes B sheet 2!, BOL!, GRA* [GRA0002730-0], K! [K000394537], SAM* [SAM0042845-0]).

Barleria prionitis sensu auctt., non L.: Clarke (1899: 144), pro parte quoad Marloth 1430; Dinter (1918: 347).

Spiny perennial herb or shrub, 20 - $100(-150) \mathrm{cm}$ tall, much branched; stems 4-angular at least when young, woody portions subterete, young stems sparsely strigulose and with fine puberulous hairs on two opposite sides or subglabrous, mature stems glabrescent and with conspicuous white flaking epidermis. Axillary spines pale brown or turning whitish, 4 (-6)-rayed, stalk $0.5-1.5 \mathrm{~mm}$ long, longest rays $3.5-$ $24 \mathrm{~mm}$ long, straight. Leaves sessile or petiole to $13 \mathrm{~mm}$ long; blade chartaceous to subcoriaceous, elliptic, oblong-elliptic or lanceolate, $2.2-9 \times 0.7-$ $3 \mathrm{~cm}$ (l:w ratio $2-4.5: 1)$, base cuneate or attenuate, margin entire, apex acute and mucronate; margin and main veins beneath sparsely strigulose or largely glabrous, often with few broad sessile glands towards base beneath; lateral veins $3-5$ pairs. Inflorescences terminal, contracted to lax spiciform or subcapitate thyrses, $1-18 \mathrm{~cm}$ long, each cymule single-flowered or rarely a second pair of bracteoles present at lowermost fertile nodes, flowers sessile; bracts foliaceous but rapidly reducing distally, \pm spreading, those midway along axis elliptic, oblong-elliptic or oblanceolate, 10 $36 \times 3-11 \mathrm{~mm}$, base cuneate, attenuate or abruptly narrowed, apex acute, obtuse or attenuate with a stiff mucro, external surface pale-strigulose on margin and main veins and with or without few to numerous broad sessile glands towards base; bracteoles whitish or pale brown, linear-lanceolate, $3-16 \times 0.3-2.5 \mathrm{~mm}$, margin entire, narrowed into a flexuose or stiff spine; pedicels 0 - $3.5 \mathrm{~mm}$ long. Calyx brown or grey-green, turning paler in fruit or before; anterior lobe ovate or lanceolate, 5 $13.5 \times 2-4 \mathrm{~mm}$, posterior lobe marginally longer, up to $14 \mathrm{~mm}$, both with base rounded or obtuse, margin entire, apex attenuate into a flexuose spine, this sometimes bifid on anterior lobe, external surfaces glabrous or strigulose, with or without scattered broad sessile glands, venation inconspicuous; lateral lobes lanceolate or linear-lanceolate, 5 - $11 \mathrm{~mm}$ long, with minute short-stalked glands along margin. Corolla yellow, orange or rarely white, $26-50 \mathrm{~mm}$ long, tube shortly retrorse-pubescent, limb glabrous or puberulous externally; tube cylindrical, 8 - $15 \mathrm{~mm}$ long; limb in marked " $4+1$ " configuration; abaxial lobe offset from the remaining lobes by $7-13.5 \mathrm{~mm}$, narrowly oblong-elliptic or oblong-lanceolate, $8.5-16 \times 3.2-6.2 \mathrm{~mm}$, apex rounded to subacute; lateral lobes elliptic or somewhat obovate, $11-24.5 \times(5.5-) 7-12 \mathrm{~mm}$, apices acute, obtuse or shortly attenuate; adaxial lobes as laterals but (4.5 -) 5.5 $-9.5 \mathrm{~mm}$ wide, apices sometimes more rounded. Stamens inserted in distal half of or midway along corolla tube; filaments 19 - $35 \mathrm{~mm}$ long; anthers exserted, 2.5 $3.8 \mathrm{~mm}$ long; lateral staminodes with filaments 1 $1.8 \mathrm{~mm}$ long, pubescent, antherodes $0.5-0.9 \mathrm{~mm}$ long. Pistil glabrous; stigma linear, 0.7 - $1.4 \mathrm{~mm}$ long. Capsule 12 - 19 mm long, glabrous; seeds $6-9 \times 4.5-7 \mathrm{~mm}$.

NOTES FOR SPECIES. The material previously united under Barleria prionitoides, or latterly B. prionitis subsp. prionitoides (Wood et al. 1983), is readily separable into three allopatric taxa. The rank at which to recognise these is open to debate but based on the evidence currently available we have treated them as subspecies of $B$. prionitoides. The two extremes, subsp. namutonensis and subsp. strigulosa, are so different that we would have no hesitation in treating them as separate species were it not for the fact that subsp. prionitoides is intermediate morphologically, although interestingly it is not the geographic intermediary but rather is the southernmost of the three taxa. The three are compared in Table 4 and are keyed out below.

Brummitt \& Wood (in Wood et al. 1983) reduced Barleria prionitoides sensu lato to a subspecies of the Indian B. prionitis L. together with six other taxa from across Africa, Arabia and India. However, we consider these taxa to be better treated as separate species, as they are easily separated morphologically and are no more similar to one another than they are to a number of other upheld species within sect. Prionitis. Barleria prionitoides is isolated both geographically and ecologically from the other African taxa previously lumped under $B$. prionitis, which in our region also includes $B$. ameliae (sp. 28 below). The conspicuous white flaking epidermis on the mature stems of B. prionitoides is diagnostic. See Darbyshire (2010b: 415) for further discussion on this group.

\section{Key to infraspecific taxa in Barleria prionitoides:}

1. Bracts attenuate at base, lacking or with only very few broad sessile glands towards base abaxially; flowers and particularly fruits pedicellate for up to $3.5 \mathrm{~mm} \ldots \ldots \ldots \ldots \ldots$. . . . . . . . . nsp. namutonensis Bracts cuneate, subattenuate or abruptly narrowed at base, with numerous broad sessile glands towards base

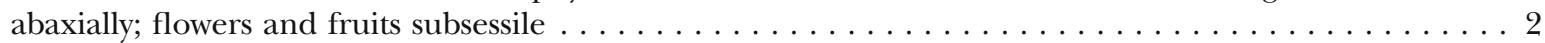

2. Outer calyx lobes glabrous externally, lanceolate, l:w ratio typically $2.5-3: 1 \ldots \ldots$. . . . a. subsp. prionitoides Outer calyx lobes pale-strigulose externally, ovate, l:w ratio typically $1.9-2.3: 1 \ldots \ldots$. . bubsp. strigulosa 
Table 4. The principal characters for separation of the three subspecies of Barleria prionitoides.

\begin{tabular}{|c|c|c|c|}
\hline Character & subsp. namutonensis & subsp. prionitoides & subsp. strigulosa \\
\hline Leaf length $(\mathrm{cm})$ & $2.8-9$ & $2.2-3.6$ & $(2.5-) 4-8.7$ \\
\hline Petiole length $(\mathrm{mm})$ & $2-10$ & $0-4$ & $(0-) 4-13$ \\
\hline Inflorescence form and length & $\begin{array}{l}\text { Spiciform, often laxly so, } \\
\text { up to } 18 \mathrm{~cm} \text { long }\end{array}$ & $\begin{array}{l}\text { Contracted, subcapitate or } \\
\text { shortly spiciform, } 1-3(-7.5) \mathrm{cm} \\
\text { long }\end{array}$ & $\begin{array}{l}\text { Spiciform or rarely } \\
\text { subcaptiate, up to } 10 \mathrm{~cm} \\
\text { long }\end{array}$ \\
\hline Bract base & Attenuate & $\begin{array}{l}\text { Cuneate, subattenuate or abruptly } \\
\text { narrowed }\end{array}$ & $\begin{array}{l}\text { Cuneate or often abruptly } \\
\text { narrowed }\end{array}$ \\
\hline $\begin{array}{l}\text { Broad sessile glands on abaxial } \\
\text { surface of bracts }\end{array}$ & Absent or sparse & Numerous and conspicuous & Numerous and conspicuous \\
\hline Pedicels & $\begin{array}{l}1-3.5 \mathrm{~mm} \text { long, extended } \\
\text { in fruit }\end{array}$ & Flowers subsessile & Flowers subsessile \\
\hline $\begin{array}{l}\text { Outer calyx lobes: shape and } \\
\text { l:w ratio (abaxial lobe) }\end{array}$ & Lanceolate, $2.5-4: 1$ & Lanceolate, $2.5-3: 1$ & Ovate, $1.9-2.3: 1$ \\
\hline $\begin{array}{l}\text { Outer calyx lobes: indumentum } \\
\text { of external surface (excluding } \\
\text { margin) }\end{array}$ & Glabrous & Glabrous & Strigulose \\
\hline Corolla length $(\mathrm{mm})$ & $(30-) 37-50$ & $37-44$ & $26-38.5$ \\
\hline Staminal filament length $(\mathrm{mm})$ & $(21-) 31-35$ & $19-23.5$ & $20-22$ \\
\hline
\end{tabular}

\section{a. Barleria prionitoides Engl. subsp. prionitoides}

Shrub, stems soon woody and stout. Leaves sessile or petiole to $4 \mathrm{~mm}$ long, blade subcoriaceous, $2.2-3.6 \mathrm{~cm}$

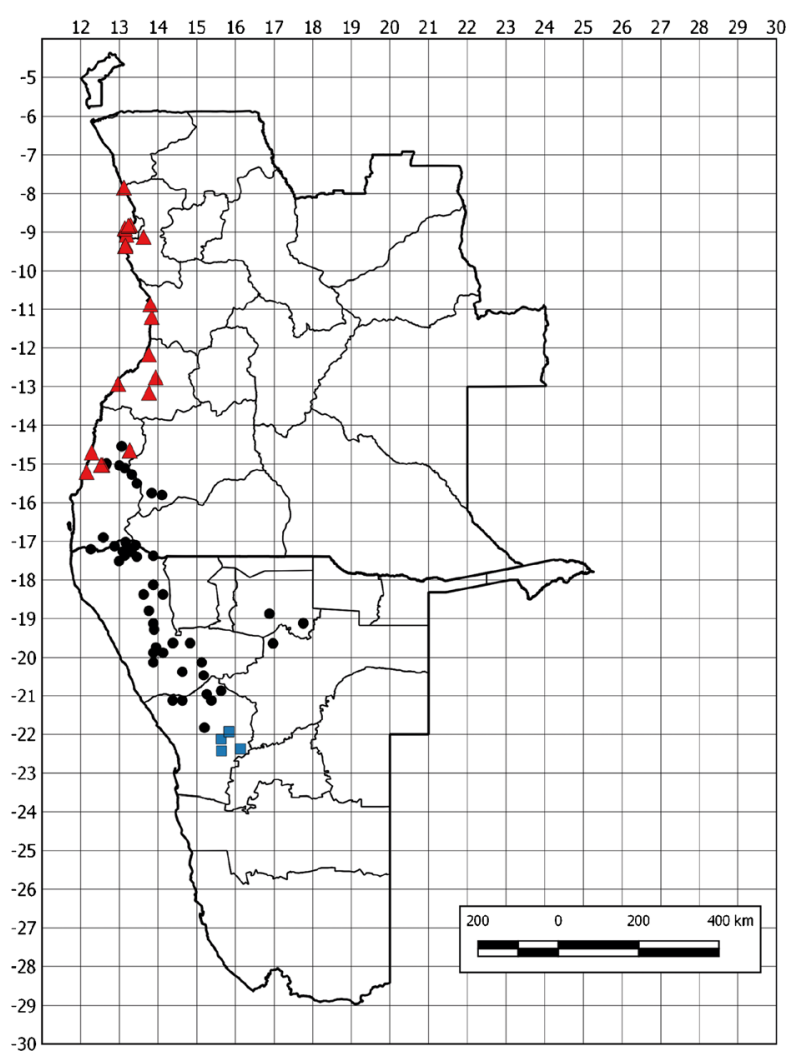

Map 10. Distribution of Barleria prionitoides: subsp. prionitoides (blue squares), subsp. namutonensis (black circles), subsp. strigulosa (red triangles). long. Inflorescences contracted, subcapitate or shortly spiciform, $1-3 \mathrm{~cm}$ long (extending up to $7.5 \mathrm{~cm}$ postfruiting); bracts with cuneate, subattenuate or abruptly narrowed base, $10-21 \mathrm{~mm}$ long at midpoint of inflorescence, broad sessile glands numerous towards base of abaxial surface; flowers and fruits subsessile. Outer calyx lobes lanceolate, $6-9.5 \mathrm{~mm}$ long, l:w ratio $2.5-$ 3: 1, external surface glabrous. Corolla 37 - 44 mm long.

DISTRIBUTION. Endemic to west-central Namibia (Erongo Region). Map 10.

ADDITIONAL SPECIMENS EXAMINED. NAMIBIA. "Ukuib" am Swakop, fl. Dec. 1907, Pogge 7 (B; photo. at K!); Dorstrivier, fl. 4 April 1913, Engler 6128 (B; photo. at K!); Farm Nudis bei Karibib, fl. 1954, Seydel 11 (M!); Karibib Distr., 17.5 miles N of Otjimbingwe, fl. \& fr. 5 March 1955, de Winter 2656 (K!, M!, PRE, WIND!); Karibib, Nudis, fl. 3 April 1955, Seydel 457 (B, K!, L!, WAG!); Farm Narubis Noord, fr. 5 July 2003, Schubert 269 (WIND!).

HABITAT \& ECOLOGY. Barleria prionitoides subsp. prionitoides has been recorded from dry open rocky ground including dry riverbeds, and from dry sandy flats; $900-1200 \mathrm{~m}$ elevation. It occurs primarily in the Western Highlands vegetation type, but just extending into the Western-central Escarpment and Inselbergs vegetation type of Mendelsohn et al. (2002).

CONSERVATION STATUS. This is by far the most rangerestricted and scarce of the three subspecies of Barleria prionitoides, with an EOO of $1,720 \mathrm{~km}^{2}$ which falls within the "Endangered" EOO threshold under IUCN criterion B1. It has only been collected once within the last 50 years despite considerable botanical exploration in central Namibia. The northernmost locality for the species in the vicinity of the town of Karibib where expansion of settlement is likely to have resulted in some local loss of habitat for this taxon. 
Elsewhere within its range, the main pressure is from livestock, in particular browsing by goats on the rocky hills that this species occupies. Not all of the historic localities have been accurately geolocated (e.g. for Pogge 7 we have been unable to place "Ukuib"), and we estimate that there are up to seven locations. With at least one of these considered to be threatened, this subspecies is provisionally assessed as Vulnerable VU B1ab(iii).

NOTE. Barleria prionitoides sensu lato has an EOO of $524,788 \mathrm{~km}^{2}$ and is locally abundant (see Conservation Status notes for the other subspecies) and so is assessed as of Least Concern - LC.

b. Barleria prionitoides Engl. subsp. strigulosa I. Darbysh. subsp. nov. Type: Angola, entre Luanda e Barra do Quenza [Cuanza], fl. 27 July 1971, Henriques 1424 (holotype LISC! [LISC043647]; isotypes LUAI!, LUBA!).

http://www.ipni.org/urn:lsid:ipni.org:names:60477555-2

Barleria prionitis var. sensu Moore (1880: 265), non L. Barleria prionitis sensu auctt., non L.: Clarke (1899:

144), pro parte quoad Welwitsch 5067, 5138, 5190,

5141 \& Monteiro s.n.; Hiern (1900: 814); Benoist (1950: 15), pro parte quoad Gossweiler 10507 \& Carrisso Ẽ Sousa 289.

Barleria prionitis L. subsp. prionitoides (Engl.) Brummitt \& J. R. I. Wood (in Wood et al. 1983: 442), pro parte \& sensu Makholela (2008: 22); non B. prionitoides Engl. sensu stricto.

Barleria prionitoides sensu Darbyshire et al. (2012: 766), pro parte, non B. prionitoides Engl. sensu stricto.

Perennial herb or subshrub, leafy stems usually herbaceous and slender, more rarely soon woody and stout. Leaves on petiole $4-13 \mathrm{~mm}$ long, blade usually chartaceous, $(2.5-) 4-8.7 \mathrm{~cm}$ long. Inflorescences spiciform, (1 -) $2.5-10 \mathrm{~cm}$ long; bracts cuneate or abruptly narrowed at base, $10-22(-30) \mathrm{mm}$ long at midpoint of inflorescence, broad sessile glands numerous towards base of abaxial surface; flowers and fruits subsessile. Outer calyx lobes ovate, 5-8 mm long, l:w ratio 1.9 - 2.3: 1 , external surface pale-strigulose. Corolla 26 - 39 mm long. Fig. 15E \& F.

RECOGNITION. Subsp. strigulosa differs from subsp. prionitoides primarily in the strigulose (vs glabrous) anterior and posterior calyx lobes which are more ovate in shape and proportionately broader (see Table 4).

DISTRIBUTION. Endemic to western Angola (Bengo, Benguela, Cuanza Sul, Luanda and Namibe Provs.). Map 10.

ADDITIONAL SPECIMENS EXAMINED. ANGOLA. Distr. Loanda [Luanda], fl. \& fr., without date, Welwitsch
5067 (B!, BM!, K!, LISU!); idem, fl. \& fr. Dec. 1853 \& Oct. 1857, Welwitsch 5138 (BM!, K!, LISU!); Ambriz, fl., without date, Welwitsch 5141 (BM!, LISU!); Ambriz, fl. Nov. 1872, Monteiro s.n. (K!); Loanda [Luanda], Maianga, fl. Feb. 1888, Welwitsch 5190 (BM!, LISU!); $\mathrm{S}$ of the town Loanda [Luanda], fl. June 1901, Gossweiler 11 (K!); between Lobito Bay and Hauha [?= Hanha], fl. 6 March 1927, Lynes s.n. (BM!); Muceque, fl. \& fr. Nov. 1935, Gossweiler 10507 (BM!); $20 \mathrm{~km}$ from Mossamedes [Namibe], fl. July 1936, Boss in TRV 35974 (PRE!); Mossamedes [Namibe], R. Mucungo, fl. 12 June 1937, Carrisso Ẽ Sousa 289 (BM!); vallée du R. Kaporolo, et ses abords (au sud est de Benguela), fr. Aug. 1937, Humbert 16122 (BM!); Hania [?= Hanha], fl. 15 March 1938, Pittard 30 (BM!); Muceque Calemba, fl. \& fr. 12 Dec. 1939, Gossweiler 12616 (BM!, LISC!); Lungo, Moçâmedes [Namibe], fl. 2 March 1956, Teixeira 716 (PRE!); Moçamedes [Namibe], Vila Arriaga, Montipa, fl. 29 May 1959, Teixeira $\mathcal{E}^{\circ}$ Andrade 4178 (LUBA!); idem, fl. \& fr. 16 June 1959, Teixeira Ẽ Santos 13 (LUBA!); andados c. $55 \mathrm{~km}$ de Moçâmedes [Namibe] para Dois Irmãos, fl. 6 May 1960, Mendes 3968 (LUBA!) — see note; Benguela, a $14 \mathrm{~km}$ do Coporolo para Benguela, fl. 14 Dec. 1962, Moreno 124 (LUBA!); Luanda, entre a Corimba e o Morro dos Veados, fl. \& fr. 9 Aug. 1963, Mendes dos Santos 1170 (BM!); foz do R. Cuvo, fl. 2 May 1967, Teixeira et al. 11580 (LISC!); Luanda Prov., Quiçama National Park, plateau near Cauá, fl. May 1972, Huntley 3110 (PRE!); Luanda, Viana, próx. da foz do R. Cuanza, fl. \& fr. 2 Feb. 1973, Santos et al. 3036 (LUAI!); Luanda, Viana-Manas da Quilunda, na área do Posto Administrativo da Barra do Kuanza, fl. 8 Feb. 1973, Henriques 1539 (LUAI!); Novo Redondo [Sumbe], fl. 29 March 1973, Bamps E Martins 4328 (BR, LISC!, WAG*); Luanda, Viana, Barra do Kwanza, ponte nova, a $75 \mathrm{~km}$ de Luanda, fl. \& fr. 10 March 1975, Daniel E Batalha 95 (LUAI!); Barra do Kwanza, junto a foz, fl. 29 March 1977, Daniel E Dala 1213 (LUAI!); Luanda, Barra do Kwanza, a 2 km de Marina, fl. 20 Dec. 1977, Batalha 381 (LUAI!); Namibe Prov., 47 km E of Namibe, fl. 23 Jan. 2009, Winter 7789 (LUBA!); idem, Winter 7790 (PRE!); Namibe, $59 \mathrm{~km} \mathrm{~S}$ of Virei en route to Pediva, fl. 16 April 2017, Tripp $\mathcal{E}$ Dexter 6957 (COLO!, K!, LUBA!) — see note.

HABITAT \& ECOLOGY. Barleria prionitoides subsp. strigulosa is recorded from dry rocky areas and sandy soils in the open or in dry thicket and desert margins; it usually occurs near the coast at elevations up to 150 $\mathrm{m}$ along the Angolan coastal plain, but in the deserts of Namibe province it is recorded up to $1000 \mathrm{~m}$ alt. (see note).

CONSERVATION STATUS. This subspecies appears locally common and widespread in the coastal areas of Angola, with an EOO of $85,050 \mathrm{~km}^{2}$. Whilst some populations are very likely to have suffered from the expansion of coastal development, most notably in 

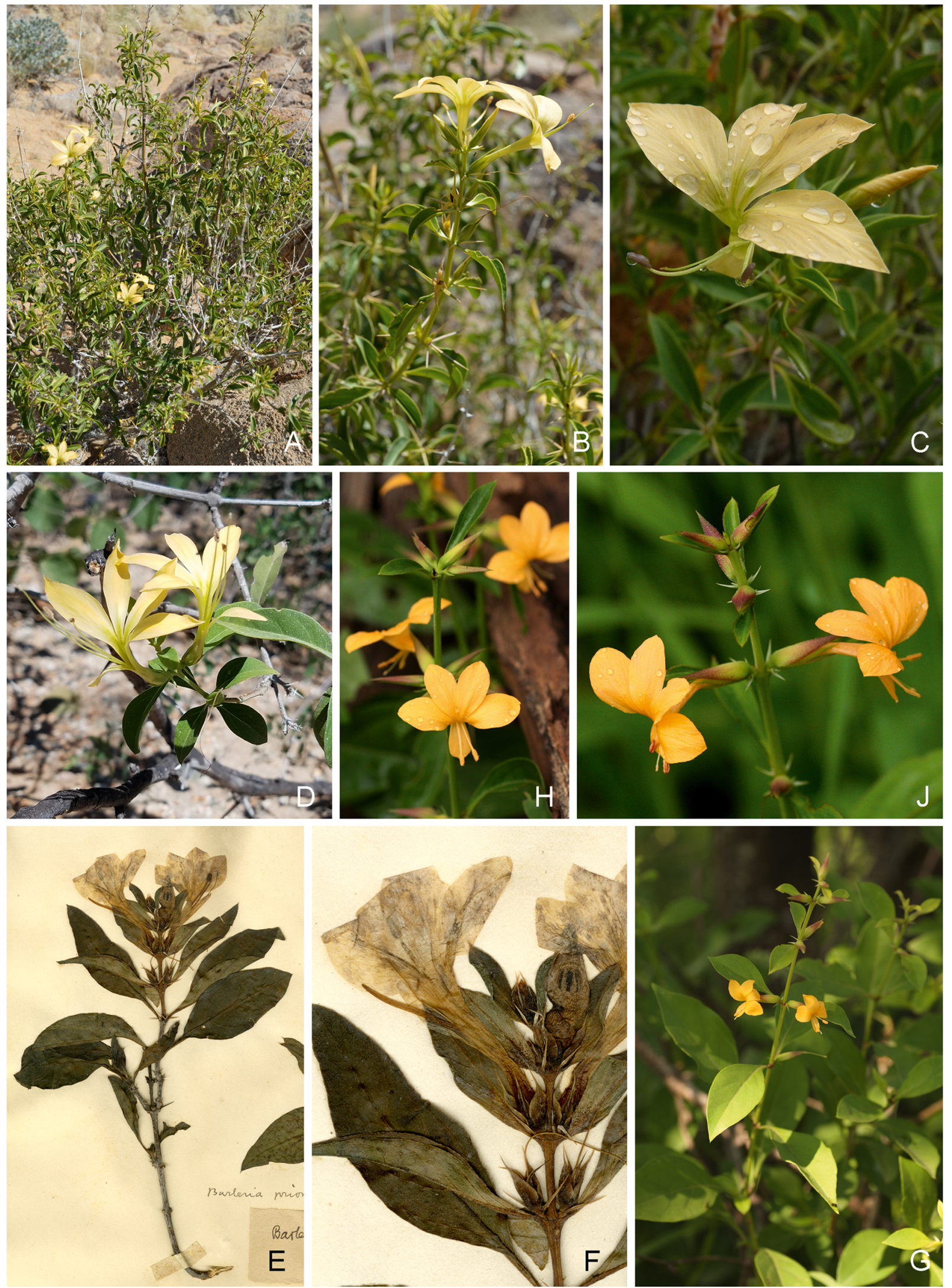

Fig. 15. A - D Barleria prionitoides subsp. namutonensis. A habit; B inflorescence; C \& D flowers. E \& F B.prionitoides subsp. strigulosa. E habit; F detail of inflorescence. G - J B. ameliae. G habit; H \& J inflorescences. C Tripp 824 (Namibia); D Tripp \& Dexter 6918 (Angola); E \& F Monteiro s.n. (K); G Hyde 10/008/01 (Zimbabwe). PHOTOS: A \& B I. DARBYSHIRE (NAMIBIA); C, D E. A. TRIPP, G - J B. WURSTEN. 
and around Luanda, it is known from many more than 10 locations and it can also tolerate some moderate disturbance - it has been noted as frequent in ruderal areas and abandoned settlements (Teixeira $\xi^{\circ}$ Andade 4178). It is therefore assessed as of Least Concern - LC.

ETYMOLOGY. The subspecies epithet "strigulosa" refers to the characteristic short strigose hairs on the external surface of the calyx lobes.

NOTES. In addition to the characters listed in the Recognition section above, the coastal Angolan plants differ quite markedly from subsp. prionitoides in having more slender, herbaceous leafy stems (soon woody in prionitoides), thinner, larger and clearly petiolate leaves and more elongate inflorescence spikes with more flowers (see Table 4). However, in the populations from the Namibe region of Angola (particularly Boss in TRV 35974, Teixeira 716 and Winter 7790) these differences break down. These plants have the shrubby habit, smaller coriaceous leaves and contracted inflorescences of subsp. prionitoides, but the ovate, (usually) strigulose calyx lobes characteristic of subsp. strigulosa. Furthermore, Mendes 3968 and Tripp E Dexter 6957 from the same region have only very sparse or absent strigose hairs on the mature calyces and so tends towards typical Barleria prionitoides. Subspecific rank therefore seems most appropriate.

c. Barleria prionitoides Engl. subsp. namutonensis (Oberm.) I. Darbysh. comb. \& stat. nov. E Barleria namutonensis Oberm., Ann. Transvaal Mus. 15: 142 (Obermeyer 1933). Type: Namibia, Klein Namutoni, fl. 28 Jan. 1919, Breyer in TRV 20646 (holotype PRE!; isotype B! [B 10 0154010]).

http:/ /www.ipni.org/urn:lsid:ipni.org:names:77192428-1

Barleria prionitis sensu Benoist (1950: 15), pro parte quoad Exell Ẽ Mendonça 2101, 2383 \& d'Abreu 71, non L.

Barleria prionitoides sensu auctt., non Engl. sensu stricto: Meyer (1957: 384; 1968: 16), pro parte; Welman (2003: 94), pro parte, Darbyshire et al. (2012: 766), pro parte.

Barleria prionitis L. subsp. prionitoides (Engl.) Brummit \& J. R. I. Wood (in Wood et al. 1983: 442), pro parte, \& sensu auctt.: Craven (1999: 152), pro parte; Makholela (2008: 22), pro parte; non B. prionitoides Engl. sensu stricto.

Perennial herb or shrub, leafy stems usually herbaceous and slender, more rarely soon woody and stout. Leaves on petiole 2 - $10 \mathrm{~mm}$ long, blade chartaceous or subcoriaceous, 2.8 - $9 \mathrm{~cm}$ long. Inflorescences laxly spiciform (rarely contracted), (2-) $3-18 \mathrm{~cm}$ long; bracts with attenuate base, 16.5 - $36 \mathrm{~mm}$ long at midpoint of inflorescence, broad sessile glands absent or sparse on abaxial surface; flowers and particularly fruits pedicellate for 1 - $3.5 \mathrm{~mm}$ long. Outer calyx lobes lanceolate, 7 $14 \mathrm{~mm}$ long, l:w ratio 2.5 - 4: 1, external surface glabrous. Corolla (30 -) 37 - 50 mm long. Fig. 15A - D.

DISTRIBUTION. Southwestern Angola (Huíla and Namibe Provs.) and northern Namibia (Erongo, Kunene, Oshikoto and Otjozondjupa regions). Map 10.

SELECTED SPECIMENS EXAMINED. (Total of 60 collections seen). ANGOLA. $\mathrm{km} 74$ along the railway from Mossamedes, fl. 19 May 1937, Exell Ẽ Mendonça 2101 (BM!); Tampa, fl. 1 June 1937, Exell E $\mathcal{F}^{2}$ Mendonça 2383 (BM!); Hoque, fl. \& fr. 15 April 1938, d'Abreu 71 (BM!); ao km 60 do apiadeiro de Dois Irmãos estrada de Vila Arriaga [Bibala], fl. 23 Dec. 1955, Torre 8282 (LUBA!); Moçamedes [Namibe], próximo de Capangombe, fl. 6 Jan. 1962, Barbosa E Moreno 9842 (K!, PRE!); Moçamedes [Namibe], Dois Irmãos, Caraculo, fl. \& fr. 9 May 1962, Santos 1045 (BM!, LUAI!, SRGH!); Gambos, ao km 61 do Pocolo, fl. 4 Dec. 1970, Menezes 3633 (LISC!, LUBA!); Gambos Cahama, km 6.3, no Morro do Covo, fl. 10 Dec. 1970, Menezes 3639 (LISC!); Iona, Iona Fountain, fr. 24 March 1972, Huntley 3077 (PRE!); 5 km from Bibala, $60 \mathrm{~km}$ from Leba village NW of Humpata, fl. 14 Jan. 2009, Voigt 102 (LUBA!, PRE!); $15^{\circ} 02^{\prime} \mathrm{S}, 13^{\circ} 00^{\prime} \mathrm{E}$, locality not specified, fl., date not recorded, Newman et al. 278 (K!); Namibe, between Moninho and Cuto, along historic Mossamedes railway, fl. 10 April 2017, Tripp E् Dexter 6918 (COLO!, K!, LUBA!). NAMIBIA. Spitzkopje, fr. May 1936, Boss in TRV 36035 (PRE!); Fransfontein, fl. May 1949, Liebenberg 4943 (K!, WIND!); Ohopoho, fl. 1957, Abner 68 (K!, PRE); 3.5 miles N of Ohopoho, fl. 29 March 1957, de Winter $\mathcal{E}^{\circ}$ Leistner 5250 (K!, M!, PRE, WIND!); Omaruru, Brandberg, Tsisab Valley, at the end of the road to "White Lady", fl. 20 Feb. 1963, Kers 1011 (WIND!); Otjipemba, fl. \& fr. 21 Jan. 1968, Grobbelaar 68 (WIND!); road Omaruru-Fransfontein, Otjihorongo Reserve, $90 \mathrm{~km} \mathrm{NW}$ of Omaruru, fl. 11 April 1968, H. Eं H. E. Wanntorp 817 (K!, S); Abzweigung nach Orumana (15 km N Orumana), fl. 20 March 1974, Merxmüller Ẽ Giess 30408 (M!, WIND!); 32 km outside Omaruru on the Omaruru-Omatjette road, fl. \& fr. 25 March 1977, Müller Ẽ Giess 392 (WIND!); Outjo Distr., along the road from Otavi to Outjo, fl. 9 March 1995, Burgoyne 3425 (PRE, WIND!); $15.1 \mathrm{~km}$ after fork to Palmwag and Kamanjab on road 2620, fl. 8 April 1995, Guise 42 (PRE!, WIND); Kunene, top of Krenz Pass, hill slopes/base of Grootberg, fl. 10 Dec. 1997, Loutit 40 (WIND!); Kunene, Kaokoveld, fl. \& fr. 11 March 2003, Schubert SS140 (WIND!); c. $3 \mathrm{~km} \mathrm{~W}$ of Kamanjab on C40, fl. 22 March 2010, Tripp 824 (K!, RSA!, WIND!); c. $20 \mathrm{~km} \mathrm{~N}$ of Okangwati, on road to Epupa falls, fl. 14 Jan. 2013, Tripp 4055 (K!, RSA!, 
WIND!); above wash W of airstrip, $4.5 \mathrm{~km} \mathrm{~S}$ of Epupa, fl. \& fr. 15 Jan. 2013, Tripp 4059 (K!, RSA!, WIND!). HABITAT \& ECOLOGY. Barleria prionitoides subsp. namutonensis has been recorded from rocky hillslopes and ridges, often on dolomite or other calcareous substrates, within open woodland, dry shrubland or semi-desert. It is frequently found growing between large boulders or along dry streambeds. It can also be found in heavily grazed areas and along roadsides; (450 -) $700-1650 \mathrm{~m}$ elevation. It is a widespread species primarily of the Kaokoveld Centre of plant endemism (sensu van Wyk \& Smith 2001). In Namibia, it occurs primarily in the Western Highlands vegetation type, but extending into the Western-central Escarpment and Inselbergs and the Karstveld vegetation type of Mendelsohn et al. (2002).

CONSERVATION STATUS. This is the most widespread and common subspecies of Barleria prionitoides, with an EOO of $229,650 \mathrm{~km}^{2}$. It is locally abundant in the Kaokoveld of northern Namibia, particularly in areas with rocky outcrops or slopes where it is one of the most commonly encountered Barleria taxa together with B. lancifolia T. Anderson. It is therefore considered to be of Least Concern - LC.

NOTES. Subsp. namutonensis shares the glabrous external surface of the calyx lobes with subsp. prionitoides, but differs in having a more laxly spiciform inflorescence, more attenuate bracts which lack or have only very few broad sessile glands towards the base abaxially, and shortly pedicellate (not sessile) flowers and fruits.

27. Barleria calole I. Darbysh. sp. nov. Type: Angola, Quissama Country, Rio Longa, fl. 10 June 1921, Gossweiler 8268 (holotype BM! [BM001010584]; isotypes $\mathrm{K}$ ! [K0010095239, K001009530]).

http://www.ipni.org/urn:lsid:ipni.org:names:77192429-1

Barleria diacantha sensu Moore (1930: 134), non Hochst. ex Nees.

Barleria trispinosa sensu Makholela (2008: 22), non (Forssk.) Vahl.

Spiny suffruticose subshrub, $80 \mathrm{~cm}$ tall; stems 4-ridged and -angular when young, at first dark brown but mature stems with pale grey epidermis giving a somewhat glaucous appearance, glabrous except for strigose nodal line. Axillary spines harsh, white or pale brown, subsessile, usually 2-rayed but some with 2 long and $1-2$ short rays, longest ray 14 $25 \mathrm{~mm}$ long, straight. Leaves on petiole to $7 \mathrm{~mm}$ long; blade chartaceous, narrowly oblong-elliptic or somewhat oblanceolate, $6.5-9.5 \times 1.8-2.8 \mathrm{~cm}$ (l:w ratio $2.4-4: 1$ ), base cuneate, margin entire, apex acute to obtuse (immature leaves rounded), with a prominent spine-tip; margin and midrib beneath sparsely pale-strigose or glabrescent, with few broad sessile glands towards base beneath; lateral veins 4 -5 pairs. Inflorescences terminal, short strobilate spikes 2.5 - $3.5 \mathrm{~cm}$ long, each cymule single-flowered, sessile; rachis bifariously puberulous; bracts highly modified from leaves, drying dark brown, basal-most pair of bracts in spike oblong, $22-27.5 \times 7-9 \mathrm{~mm}$, all other bracts ovate, $17-19 \times 8.5-12 \mathrm{~mm}$, base rounded and abruptly narrowed, apex acuminate into a prominent stiff spine up to $4.5 \mathrm{~mm}$ long, external surface pale-strigose on margin, midrib and sparsely on main veins, often with few scattered broad sessile glands; bracteoles whitish with darker midrib, linear-lanceolate, $7-8 \times 1-1.5 \mathrm{~mm}$, acuminate into a flexuose spine, margin entire. Calyx hidden within bracts, brown; anterior and posterior lobes subequal, broadly ovate, $6-7 \times 4-4.5 \mathrm{~mm}$, base obtuse, margin entire, apex \pm abruptly narrowed into a short acumen $0.3-0.7 \mathrm{~mm}$ long and often bifid on anterior lobe, $0.7-1.7 \mathrm{~mm}$ long and linear on posterior lobe, external surfaces puberulous and with scattered broad sessile glands, venation inconspicuous; lateral lobes lanceolate, 4.5 - $5 \mathrm{~mm}$ long, shortly acuminate. Corolla yellow, 47 $51 \mathrm{~mm}$ long, glabrous externally except for few short inconspicuous hairs on fused portion beyond abaxial lobe; tube cylindrical, 18 - $19 \mathrm{~mm}$ long; limb in marked " $4+1$ " configuration; abaxial lobe offset from remaining lobes by 12.5 - $15 \mathrm{~mm}$, narrowly oblong, $17.5-18 \times 5.5-6.5 \mathrm{~mm}$, apex acute; lateral lobes broadly obovate, $16-18 \times 11-12.5 \mathrm{~mm}$, apices rounded and with a minute apiculum; adaxial lobes as lateral lobes but $8-8.5 \mathrm{~mm}$ wide. Stamens inserted in distal half of corolla tube; filaments $28-30 \mathrm{~mm}$ long, sparsely and minutely hairy towards base; anthers exserted, 4.2 - $4.5 \mathrm{~mm}$ long; lateral staminodes 2.5 - $3 \mathrm{~mm}$ long, filaments pubescent, antherodes 0.7 - $1.2 \mathrm{~mm}$ long. Pistil glabrous; stigma linear, $1-1.2 \mathrm{~mm}$ long. Capsule not seen. Fig. 14A - H.

RECOGNITION. Barleria calole resembles Barleria trispinosa (Forssk.) Vahl but differs in having much more clearly differentiated bracts (broadly ovate) from the leaves (narrowly elliptic or oblanceolate), in the bracts being more chartaceous with less prominent lateral veins and with longer, more conspicuous strigose hairs along the midrib and margin, and in having more membranous calyces.

DISTRIBUTION. Endemic to western Angola (Bengo Prov.) and known only from the type. Map 9.

SPECIMEN EXAMINED. ANGOLA. Quissama Country, Rio Longa, fl. 10 June 1921, Gossweiler 8268 (BM! holotype, $\mathrm{K}$ ! isotypes).

HABITAT \& ECOLOGY. The single collection of Barleria calole was recorded from Euphorbia conspicua thicket of coastal, central Angola. The elevation was 
not recorded but the general area of the collection is at low altitude. Lebrun \& Stork (2006) note that E. conspicua occurs in coastal areas about $3 \mathrm{~km}$ inland, between Ambriz and Benguela, especially around Luanda.

CONSERVATION STATUS. This species is considered likely to be globally scarce, as it is known from only a single collection and has not been recorded for almost 100 years, despite having large, showy flowers. The Longa River flows into the Atlantic Ocean between Luanda and Lobito; there has been considerable loss of natural habitat in this heavily populated coastal zone and this is likely to have impacted the Euphorbia conspicua woodland and thicket in some areas. However, it is unclear as to where exactly on the Longa River Gossweiler collected his specimen. With so little information on its range, exact habitat requirements and threats, this species must be considered Data Deficient - DD at present, but it may well prove to be globally threatened.

ETYMOLOGY. The epithet "calole" denotes the local vernacular name for this species, as recorded by Gossweiler 8268 (on K001009530): "calole is the native name".

NOTES. Despite the major range disjunction, there is little doubt that this species is closely allied to Barleria trispinosa from northeast Africa and Arabia. They share contracted, strobilate terminal inflorescences, small ovate calyces which are puberulous and with broad sessile glands, and large corollas that are largely glabrous. They are most easily separated by the more marked differentiation between the leaves and bracts in B. calole, both in terms of shape and texture. Barleria trispinosa has rather variably shaped bracts, ranging from elliptic to ovate or obovate, but in those plants that have ovate bracts similar in shape to $B$. calole, the leaves are also proportionately broader and ovate or at most elliptic, not narrowly elliptic or oblanceolate as in B. calole. The bracts on the single specimen of $B$. calole seen have dried brown and with inconspicuous venation; those of $B$. trispinosa dry green and have prominent lateral veins. We also suspect that there is a difference in habit, as $B$. calole was described as a suffruticose subshrub by Gossweiler, whilst B. trispinosa is a shrub. Unfortunately, the basal parts are missing from the Gossweiler collection so we cannot confirm that it branches from a woody base, but the slender erect stems would support this possibility. Further material of $B$. calole is highly desirable to investigate these differences further; there may be additional differences in, for example, the fruits. It is likely that these two species are a further example of vicariant taxa found at opposite ends of the putative African arid corridor (Verdcourt 1969; de Winter 1971), although most southwest African examples of this phenomenon are recorded from further south, in the Namib Desert.
This species does not appear to be closely allied to the other Angolan and Namibian species in sect. Prionitis and is unlikely to be confused in the region.

28. Barleria ameliae A. Meeuse (1961: 443); Craven (1999: 152); Welman (2003: 93); Klopper et al. (2006: 3); Darbyshire et al. (2012: 766); Klaassen \& Kwembeya (2013: 128); Darbyshire (2015: 114). 三 Barleria priointis L. subsp. ameliae (A. Meeuse) Brummitt \& J. R. I. Wood (in Wood et al. 1983: 441); Craven (1999: 152); Mapaura et al. (2004: 13); Klopper et al. (2006: 3). Type: Namibia, Caprivi Strip, Mpilila Island, fl. 15 Jan. 1959, Killick E E Leistner 3391 (holotype PRE; isotypes K! [K000394535, K000394536], L, M! [M0109645], SRGH, WIND).

Barleria prionitis sensu Clarke (1899: 145), pro parte quoad Buchanan s.n. ex Malawi; non L.

Barleria eranthemoides C. B. Clarke (1899: 147), pro parte quoad Buchanan s.n. \& Meller s.n. ex Malawi; non $B$. eranthemoides sensu stricto, lectotypified by Darbyshire (2010b: 436).

Perennial herb or subshrub, erect or decumbent, 15 $120 \mathrm{~cm}$ tall, often rooting at lower nodes; stems 4angular, glabrous or minutely puberulous, woody portion of stems with pale grey or sandy-coloured bark. Axillary spines present but inconspicuous, pale brown or whitish, 4-rayed, stalk to $1 \mathrm{~mm}$ long, longest ray $2-7 \mathrm{~mm}$ long. Leaves on petiole to $13 \mathrm{~mm}$ long, blade elliptic or elliptic-obovate, 4.8 $10.5 \times 1.6-4.7 \mathrm{~cm}$ (1:w ratio 2 - 3.5: 1), base cuneate-attenuate, long-decurrent, margin entire, apex acute or attenuate, tip mucronulate, margin, midrib and veins beneath strigose, later glabrescent. Inflorescences axillary or a \pm weakly defined terminal spike, 2.5 - $22 \mathrm{~cm}$ long, lax or rarely contracted, each cymule 1- or 3-flowered, sessile; bracts \pm spreading, lower pairs foliaceous, gradually reducing distally where oblanceolate, $11-38(-48) \times 2.5-15$ $\mathrm{mm}$, apex acute or shortly attenuate, mucronate, hairs as leaves beneath or more widespread; bracteoles white-green, lanceolate-spinose, $2.5-10.5 \times$ $0.8-1.2 \mathrm{~mm}$, margin entire. Calyx green, often paler towards base or pale green throughout; anterior and posterior lobes subequal, ovate or lanceolate, anterior lobe $10.5-14(-16.5) \times 3-$ $5.5 \mathrm{~mm}$, posterior lobe $11-17$ (- 20) $\mathrm{mm}$ long, margin entire, apex acute or attenuate, spinose, anterior lobe sometimes notched, external surface strigose, rarely also with few short glandular hairs towards apex, venation parallel, prominent in fruit; lateral lobes linear-lanceolate, 10 - $14 \mathrm{~mm}$ long. Corolla yellow, orange or apricot, 27 - $40 \mathrm{~mm}$ long, pubescent externally with mixed glandular and eglandular hairs; tube cylindrical, 10 - $18 \mathrm{~mm}$ long; limb in " $4+1$ " configuration; abaxial lobe offset from 
remaining lobes by $4.5-8 \mathrm{~mm}$, (elliptic-) obovate, $9-14 \times 5-7.5 \mathrm{~mm}$, apex rounded or obtuse; lateral and adaxial lobes subequal, elliptic, $11-16 \times$ $6.5-8.5 \mathrm{~mm}$ or adaxial lobes narrower, minimum $4.5 \mathrm{~mm}$ wide, apices obtuse or acute. Stamens inserted $8-11 \mathrm{~mm}$ from base of corolla tube; filaments $11.5-21 \mathrm{~mm}$ long, pubescent in proximal two thirds; anthers 2.5 - $4 \mathrm{~mm}$ long; lateral staminodes 1.3 - $2 \mathrm{~mm}$ long, pubescent, antherodes $\pm 1 \mathrm{~mm}$ long. Pistil glabrous or ovary minutely hairy; stigma linear, 0.7 - $1.1 \mathrm{~mm}$ long. Capsule 13 $16 \mathrm{~mm}$ long, glabrous or sparsely and minutely hairy; seeds $7-8 \times 4.5-6 \mathrm{~mm}$. Fig. $15 \mathrm{G}-\mathrm{J}$.

DISTRIBUTION. Namibia (Zambezi Region); Mozambique, Malawi, Zambia, Zimbabwe, South Africa (Mpumalanga Prov.), eSwatini. Map 11.

ADDITIONAL SPECIMENS EXAMINED. NAMIBIA. Impalela [Mpalila] Island, by Militere Basis aan N kant, fl. 24 March 1976, du Preez 5 (17285) (PRE!, WIND!).

HABITAT \& ECOLOGY. In Namibia, Barleria ameliae has been recorded from poorly drained scrub on gravelly clay soils; c. $900-950 \mathrm{~m}$ elevation. Elsewhere within its range it is widespread in drier woodland types within the Zambesian Regional Centre of Endemism (White 1983), most notably in Colophospermum mopane and Acacia woodland on sandy soils, but also recorded from dry open riverine forest and thicket, and from seasonally inundated Acacia wooded-grassland.

CONSERVATION STATUS. This species is highly restricted in Namibia, being known only from Mpalila Island in Zambezi Region (formerly the Caprivi Strip) where it was recorded as rare by $\mathrm{P}$. du Preez. Much of the woodland habitat in the Zambezi Region has been degraded and so this species is likely to be nationally threatened under IUCN criterion B. However, on a global scale this species is widespread and fairly common in drier Zambesian woodlands and, although the complete EOO has not been calculated, it is known to be in excess of $800,000 \mathrm{~km}^{2}$. Therefore, it is not considered to be globally threatened and has been assessed as of Least Concern - LC (Darbyshire 2015).

NOTES. Darbyshire (2015) recorded this species as being restricted to the Flora Zambesiaca region, but a recent loan of southern African specimens of Barleria sect. Prionitis from PRE to $\mathrm{K}$ has revealed that it also occurs in eSwatini and eastern Mpumalanga.

29. Barleria senensis Klotzsch (1861: 209); Clarke (1899: 146); Meyer (1968: 17); Balkwill \& Balkwill (1997: Figs. 5D, 7A - C, 8M, 11Q \& T); Craven (1999: 152); Welman (2003: 94); Klopper et al. (2006: 5); Makholela (2008: 22); Darbyshire et al. (2012: 766); Klaassen \& Kwembeya (2013: 129); Darbyshire (2015:
115, Fig. 8.6.44). Type: Mozambique, Rios de Sena, fl., without precise date $(1842-1846)$, Peters s.n. (lectotype B! [B 10 0190529], selected by Darbyshire, l.c.; isolectotypes B! [B 10 0190528, B 10 0190530]).

Barleria eenii S. Moore (1907: 229); Dinter (1918: 347); Obermeyer (1933: 178); Meyer (1957: 380). Type: Namibia, Damaraland, fl. 1879, Een s.n. (holotype BM! [BM000931097]).

Barleria petrophila Lindau (1909: 353); Dinter (1918: 347); Obermeyer (1933: 178). Type: Namibia, Omburo, fl. Feb. 1900, Dinter 1412 (holotype B $\uparrow$ ).

Barleria spathulata N. E. Br. (Brown 1909: 128); Dinter (1918: 347); Obermeyer (1933: 144). Type: Botswana, Kwebe, fl. 18 April 1898, Lugard 5A (holotype K! [K000394571]; isotype GRA* [GRA0002733-0]).

Barleria albida Lindau (1920: 22); Obermeyer (1933: 178). Type: Namibia, Hereroland, Franzfontein Outjo, fl. \& fr. 9 June 1912, Dinter 2646 (holotype $\mathrm{B} \dagger)$.

Barleria prionitoides sensu Burke (2005: 36 - 37), non Engl.

Perennial herb or shrub, erect or straggling, 25 - 150 ($300) \mathrm{cm}$ tall; stems at first 4-angular, later subterete, glabrous or uppermost internodes minutely puberulous on two opposite sides. Axillary spines small, often sparse, sometimes absent, 4 (-6)-rayed, stalk to $1.5 \mathrm{~mm}$ long, longest ray $1.5-7.5 \mathrm{~mm}$ long. Leaves sometimes immature at flowering, sessile or petiole to $10 \mathrm{~mm}$ long; mature blade elliptic (-lanceolate) or somewhat obovate, $4-14 \times 1-6 \mathrm{~cm}$ (1:w ratio $1.9-3.5$ $(-4): 1)$, base cuneate or attenuate, margin entire, apex acute or attenuate, apiculate, leaf buds densely pale-strigose but mature leaves soon glabrescent except along margin and midrib beneath; lateral veins $4-5$ pairs. Inflorescences contracted spikes or heads $1.5-8 \mathrm{~cm}$ long terminating main and short lateral branches, sometimes with additional flowers in distal leaf axils, each cymule of the spike 1 (-3)-flowered; bracts often white in proximal half, green above and along main veins, or green throughout, obovate to broadly spathulate, $7.5-16 \times 3.5-12.5 \mathrm{~mm}$, apex rounded, truncate or emarginate then shortly attenuate into a mucro, main veins and margin of distal half strigose, margin of proximal half usually with spreading, bulbous-based hairs, surface with short (rarely subsessile) glandular hairs in distal half, sometimes with interspersed finer short eglandular hairs, few broad sessile glands usually present towards base; bracteoles white with green midrib or more rarely green with pale margin, linear-lanceolate or lanceolate, $(5.5-) 7.5-14 \times 1-2 \mathrm{~mm}$, mucronate, margin entire. Calyx lobes green with paler margins, later turning whitish-green; anterior and posterior lobes lanceolate, $7-12.5 \times 2.5-4 \mathrm{~mm}$, margin entire, apex acute or attenuate, mucronate, anterior lobe sometimes notched, with few short eglandular and glandu- 
lar hairs towards apex, sometimes with longer ascending hairs along margin, venation inconspicuous; lateral lobes somewhat narrower. Corolla yellow, orange, apricot or ochre, 23 - $36 \mathrm{~mm}$ long, pubescent externally, limb with mixed eglandular and glandular hairs; tube 9 - $15.5 \mathrm{~mm}$ long; limb in " $4+1$ " configuration; abaxial lobe offset by $4-9 \mathrm{~mm}$, obovate or elliptic, $8.5-13.5 \times 5.5-8.5 \mathrm{~mm}$, apex rounded or obtuse; lateral lobes as abaxial lobe but $10-15 \times 6-9$ $\mathrm{mm}$, apices often acute; adaxial lobes $9.5-14 \times 5.5-8$ $\mathrm{mm}$. Stamens inserted $7-11 \mathrm{~mm}$ from base of corolla tube; filaments $12-20 \mathrm{~mm}$ long, shortly pubescent in proximal half to two thirds; anthers $2.5-3.5 \mathrm{~mm}$ long; lateral staminodes 0.5 - $1.5 \mathrm{~mm}$ long, pilose, antherodes $0.6-1.1 \mathrm{~mm}$ long. Pistil glabrous; stigma linear, 0.6 - $1 \mathrm{~mm}$ long. Capsule 12 - $17 \mathrm{~mm}$ long, glabrous; seeds $7.5-9 \times 4.5-6 \mathrm{~mm}$. Fig. 16 .

DISTRIBUTION. Southeastern Angola (Cuando Cubango Prov.), northern Namibia (Erongo, Kavango East, Kunene, Omaheke, Omusati, Oshikoto and Otjozondjupa regions); widespread in southern Africa: Malawi, Mozambique, Zambia, Zimbabwe, Botswana and South Africa (Limpopo \& Mpumalanga Provs.). Map 9.

SELECTED SPECIMENS EXAMINED. (Total of 54 Angolan and Namibian collections seen). ANGOLA. Santa Cruz Mission, Mashi R., fl. \& fr. 12 Aug. 1952, Codd 7532 (BM!, K!, PRE!); $60 \mathrm{~km} \mathrm{WNW} \mathrm{of} \mathrm{Dirico,} \mathrm{fl.} \mathrm{\&} \mathrm{fr.} 11$ June 2015, Barker et al. 301 (K!, LUBA!, PRE). NAMIBIA. Nama Pan, fl. \& fr. 22 Aug. 1955, Story 5274 (K!, M!, PRE); Kaokoveld, 6 miles W of Ohopoho, fl. 27 March 1957, de Winter E Leistner 5199 (K!, M!, PRE, WIND!); Kaokoveld, 43 miles from Ombombo on road to Warmbad, fl. \& fr. 22 May 1957, de Winter Ẽ Leistner 5885 (K!, M!, PRE, WIND!); Farm Ameib in Erongo Mts, c. 18 miles W of Usakos, fl. 18 March 1963, de Winter Eै Hardy 8079 (K!, M!, PRE, WAG*, WIND!); 6 miles from Omaruru on Karibib road, fl. 17 March 1965, Hardy 2020 (PRE, WIND!); Outjo, 2 miles $\mathrm{N}$ of Otjovasandu, Etosha, fl. 30 May 1966, Joubert 175 (WIND!); Orunjarara, $16 \mathrm{~km} \mathrm{~W}$ der Omuramba Omatako Mündung, fl. \& fr. 3 Oct. 1966, Giess 9528 (K!, LISC!, M!, WIND!); Etosha N.P., Klein Kowares, fl. \& fr. April 1975, le Roux E Berry 1505 (WIND!); Omatjette, fl. 25 March 1977, Müller E Giess 393 (M!, WAG!, WIND!); about $5 \mathrm{~km} \mathrm{SE}$ of Nama pan, Southern Bushmanland, fl. 3 March 1986, Hines 670 (WIND!); Kavango, W of Khaudum, fl. \& fr. 1 May 1999, Burke 99115 (WIND!); 52 km from Mkwasi Camp on road to Bagani, fl. \& fr. 23 May 1999, Austaller et al. SA 20 (WAG!, WIND!); Loskop Farm (Cravens); approx. $10 \mathrm{~km}$ from Omaruru (south), fl. \& fr. 11 May 2000, Zimmerman E Joubert 65 (WIND!); Otjinene Distr, Eiseb Omuramba, fl. 13 May 2001, Uiras MU367 (WIND!); Etosha N.P., Okaukuejo Rest Camp, fl. 23 March 2006, Berriman BER2/125
(WIND!); on C40 between Sesfontein and Opuwo, fl. \& fr. 23 March 2010, Tripp E Dexter 838 (K!, RSA!, WIND!); on the D2351 towards Omaruru, old infl. 21 Jan. 2013, Tripp 4105 (K!, RSA!, WIND!).

HABITAT \& ECOLOGY. Barleria senensis is recorded from a variety of habitats on sandy soils, most commonly in open to dense bushland, woodland and scrub of variously Acacia, Boscia, Burkea, Colophospermum mopane and Terminalia. It sometimes occurs along riverbanks or dry riverbeds (more commonly so in the eastern part of its range than in our area). It is tolerant of disturbance and is sometimes recorded in overgrazed or disturbed sites including roadsides. It occurs at 1050 - $1550 \mathrm{~m}$ elevation. It is a widespread species of southern tropical Africa associated primarily with the Zambesian Regional Centre of Endemism of White (1983). In Namibia, it occurs in the Western Highlands, Thornbush Shrubland, Karstveld, North-eastern Kalahari Woodland and Northern Kalahari vegetation types of Mendelsohn et al. (2002).

CONSERVATION STATUS. Barleria senensis is a widespread and common species of southern tropical Africa. Although the complete EOO has not been calculated, it is known to be in excess of 1.5 million $\mathrm{km}^{2}$. Collections data indicate that it is tolerant of some habitat disturbance including grazing pressure. It is not considered to be threatened and is assessed as of Least Concern - LC.

NOTES. Barleria senensis is easily identified by the terminal flowering spike with obovate to spathulate imbricate bracts which enclose the basal portion of the flowers. In much of its range, the bracts have a white portion towards the base and also have characteristic bulbous-based hairs along the margin. However, the bracts in populations in the southwest of its range often lack the conspicuous white portion and can have less prominently bulbous-based hairs along the margin. This form was previously separated as B. eenii; however, the variation is clearly clinal and cannot be readily separated into distinct taxa.

Makholela (2008: 22) cited the type specimen as being from Angola, but Rios de Sena is in Mozambique.

30. Barleria coriacea Oberm. (Obermeyer 1933: 139); Compton (1976: 552); Darbyshire (2015: 119). Type: South Africa, near Zebedeli's Kraals, Inkumpi R., fl. \& fr., without date, Nelson 370 (holotype PRE; isotype K! [K000394539]).

Barleria prionitis sensu Clarke (1901: 46), pro parte quoad Nelson 370 \& 400; non L.

Compact spiny subshrub, $5-50 \mathrm{~cm}$ tall; stems with variable internode length, sometimes with many contracted internodes and spiny nodes; branches 4-angular, whitepuberulous and sometimes strigulose when young, hairs concentrated on two opposite sides or more widespread, 
later glabrescent; mature stems soon becoming woody and stout, with grey bark. Axillary spines white, $2-4$ (-6)-rayed, stalk $0-2.5 \mathrm{~mm}$ long, longest ray $5-23.5 \mathrm{~mm}$ long, straight. Leaves often held \pm erect at least towards apex of stems, sessile or petiole to $6 \mathrm{~mm}$ long; blade somewhat coriaceous, narrowly oblong or oblanceolate, $2.5-7.3 \times 0.8$ - $2.2 \mathrm{~cm}$ (1:w ratio (2.6 -) $2.8-4.6: 1$ ), base cuneate or attenuate, margin entire, apex acute to rounded, mucronate, young leaves with few to numerous appressed short white hairs, these later sparse and mainly along margin and veins beneath or glabrescent, broad sessile glands \pm numerous towards base beneath; lateral veins $3-5$ pairs. Inflorescences axillary but sometimes clustered towards stem apices to form loose leafy spikes; flowers solitary at each axil, sessile; bracts foliaceous, often with more numerous and conspicuous sessile glands towards base; bracteoles white, spinose, (8-) $11-27 \times 1-2.5 \mathrm{~mm}$, margin entire. Calyx (greenish-) white, anterior and posterior lobes subequal, lanceolate, anterior lobe $10.5-15(-20) \times 3-$ $5 \mathrm{~mm}$, posterior lobe $11-16(-22) \mathrm{mm}$ long, both longattenuate into apical spine, anterior lobe sometimes bifid, margin entire, external surfaces and margins sparsely strigulose or glabrescent, with scattered broad sessile glands, 2 (anterior) or 1 (posterior) vein(s) prominent; lateral lobes linear-lanceolate, 9 - $13 \mathrm{~mm}$ long. Corolla yellow or pale orange, $29-48 \mathrm{~mm}$ long, glabrous externally or tube with short hairs; tube cylindrical, 10.5 - $16 \mathrm{~mm}$ long; limb in " $4+1$ " configuration; abaxial lobe offset by 4 $10 \mathrm{~mm}$, this and lateral lobes broadly (ovate-) elliptic or obovate, $12-20 \times 7-13 \mathrm{~mm}$, apices acute, attenuate or rounded with minute acumen; adaxial lobes narrower, 6 $9 \mathrm{~mm}$ wide. Stamens inserted $7-9 \mathrm{~mm}$ from base of corolla tube, filaments $15-26 \mathrm{~mm}$ long, shortly pubescent; anthers (3 -) 3.5 - $6 \mathrm{~mm}$ long; lateral staminodes 1 $1.7 \mathrm{~mm}$ long, pilose, antherodes $0.4-1.2 \mathrm{~mm}$ long. Pistil glabrous; stigma linear, $1-2 \mathrm{~mm}$ long. Capsule 13 $17.5 \mathrm{~mm}$ long, glabrous; seeds $7-8 \times 5.5-6.5 \mathrm{~mm}$.

Barleria coriacea Oberm. subsp. dinteri (Oberm.) I. Darbysh. comb. \& stat. nov. $\equiv$ Barleria dinteri Oberm., Ann. Transvaal Mus. 15: 140 (Obermeyer 1933); Meyer (1957: 380; 1968: 14); Craven (1999: 152); Welman (2003: 93), pro parte; Klopper et al. (2006: 4); Darbyshire et al. (2012: 766); Mannheimer (2012: 370); Klaassen \& Kwembeya (2013: 129). Type: Namibia, Kalkfontein - Witvley, fl. 18 March 1911, Dinter

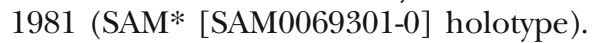

http:/ /www.ipni.org/urn:lsid:ipni.org:names:60477537-2

Barleria quadrispina sensu Dinter (1918: 347), non Lindau.

Often a very compact shrublet with contracted internodes. Immature leaves with \pm numerous appressed short white hairs throughout, giving the young foliage a glaucous appearance. Bracteoles (11 -) 14 $27 \mathrm{~mm}$ long. Corolla lobes with apices usually acute or attenuate. Fig. 17A - C.

DISTRIBUTION. Endemic to southern Namibia (Hardap and Karas Regions). Map 11.

SELECTED SPECIMENS EXAMINED. (Total of 25 collections seen). NAMIBIA. Bullsport, fl. \& fr. 4 April 1911, Dinter s.n. (SAM*); Bull's Mouth Pass, fr. 27 Dec. 1915, Pearson 8918 (K!); Naukloof Mts at Bullspoort, fl. bud 16 Dec. 1947, Strey 2037 (BOL!); Bullsport Farm, fl. bud May 1949, Strey 2704 (PRE!); Namaqualand, 50 miles N of Mariental, fl. \& fr. 17 Feb. 1950, MacDonald 382 (BM!); Farm Friedland, Hohe Achtberg, fl. 18 March 1953, H. Eं E. Walter 1913 (WIND!); Rehoboth Distr., 5.7 miles $\mathrm{S}$ of Kalkrand on road to Mariental, fl. 10 May 1955, de Winter 3500 (K!, PRE); Mariental, Farm Haribes, fl. April 1956, Volk 12401 (M!, WIND!); Keetmanshoop, 22 miles E of Koës, fl. 9 April 1960, Leistner 1794 (K!, M!, PRE!); Rehoboth Distr., 16 miles from Stampriet on the road to Uhlenhorst, fl. 29 April 1960, van Vuuren $\mathcal{E}^{\circ}$ Giess 1165 (K!, M!, PRE, WIND!); Gibeon Distr., Mariental, Kalkrandplateau, etwa 8 Meilen oestlich von Mariental am Weg nach Windhoek, fl. \& fr. 2 March 1963, Giess et al. 5599 (M!, WIND!); Farm Kalkpan, fl. 1 Nov. 1964, Kotze in Giess 10494 (WIND!); Farm Hansa, KEE 178, fl. \& fr. 25 Jan. 1965, Giess 8376 (M!, WIND!); Naukluft Plateau, Dist. Maltahöhe, fr. 30 July 1972, Meyer 496 (WIND!); Rehoboth Distr., Büllsport 172, at old police station, st. 25 May 1975, Griffin 92 (WIND!); Mariental, Hardap Wild Reserve, fl. 14 16 March 1978, Müller 931 (M!, WIND!); S of Naukluft N.P., Kyffhauser Farm, fl. 12 March 1995, Burgoyne 3531 (PRE!); Kyffhauser Farm, on road to Solitaire, fl. 12 March 1995, Germishuizen 7889 (PRE, WIND!) — see note; Farm Clara 180, \pm $1 \mathrm{~km} \mathrm{~S}$ of house along C29, fl. \& fr. 19 Feb. 1998, Strohbach 3665 (WIND!); $124 \mathrm{~km} \mathrm{~S}$ of Rehoboth on B1, st. 25 Aug. 2011, Tripp Ẽ Dexter 2032 (K!, RSA!, US!, WIND!).

HABITAT \& ECOLOGY. Barleria coriacea subsp. dinteri is recorded from open bushland and dwarf shrubland on sandy plains, dry pans, alluvial deposits and rocky hillslopes; sometimes on calcareous soils; 1000 - 1550 $m$ elevation. It occurs in the Dwarf Shrub Savanna, Desert-Dwarf Shrub Transition, and Karas Dwarf Shrubland vegetation types of Mendelsohn et al. (2002).

CONSERVATION STATUS. Barleria coriacea subsp. dinteri is restricted to southern Namibia where it is rather localised, with an EOO of $38,724 \mathrm{~km}^{2}$. This is above the "Vulnerable" threshold of $20,000 \mathrm{~km}^{2}$ for IUCN criterion B1. Furthermore, it appears to be reasonably frequent within its range. The most likely threat within its range is the impact of browsing pressure from goat herds, but it is not clear how much this impacts this species. It is currently assessed as of Least Concern - LC. 


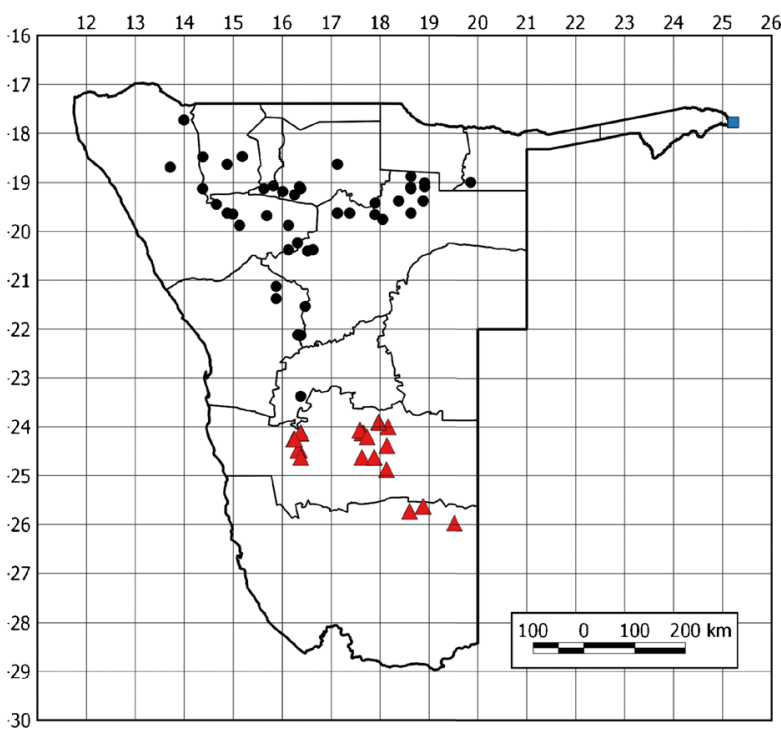

Map 11. Distribution of Barleria ameliae (blue square Namibian range only), $B$. coriacea subsp. dinteri (red triangles) and B. kaloxytona (black circles).

NOTES. Subsp. coriacea from Botswana, Northeast South Africa and Swaziland differs primarily in having the hairs on the young leaves restricted to the margin and veins beneath, such that the blade never appears glaucous (see Darbyshire 2015). It also usually has more rounded apices to the corolla lobes, sometimes with a short acuminate tip. It is often less compact, with longer internodes, and can have shorter bracteoles $11-18.5 \mathrm{~mm}$ long, but there is considerable overlap in these characters. Populations from the Dongola Botanical Reserve, Limpopo Prov., South Africa (e.g. Pole-Evans 1910, K!, PRE!), well within the range of subsp. coriacea, appear very close to smallflowered forms of subsp. dinteri (see below) particularly in the long bracteoles and the acute corolla lobes. Indeed, Obermeyer (1933) included Muhlopi in Nat. Herb. 3278 from this site within her B. dinteri. This population requires further investigation.

From the limited flowering material of subsp. dinteri seen, two forms are potentially recognisable. The first (which includes the type) has small corollas $30-35 \mathrm{~mm}$ long with at least a few hairs on the tube and has small anthers (3-) $4-4.5 \mathrm{~mm}$ long. The second, from the SE part of the Namibian range (e.g. Strohbach 3665), has large, glabrous corollas 37 $48 \mathrm{~mm}$ long, and anthers 4.3 - $6 \mathrm{~mm}$ long. Unfortunately, there are rather few good flowering specimens available such that the consistency of these differences cannot be confirmed. We have therefore chosen to treat them within a single taxon for the time being.

A population from Kyffhausen Farm (Burgoyne 3531; Germishuizen 7889) is rather atypical, having small flowers with more rounded lobe apices and with small anthers; these plants also have smaller, greener bracteoles and calyces than typical subsp. dinteri.

31. Barleria kaloxytona Lindau (1909: 354); Dinter (1918: 347); Obermeyer (1933: 142); Meyer (1957: 381; 1968: 14); Craven (1999: 152); Welman (2003: 93); Klopper et al. (2006: 4); Darbyshire et al. (2012: 766); Klaassen \& Kwembeya (2013: 129). Type: Namibia, Omburo, fl. \& fr. 2 Feb. 1900, Dinter 1399 (lectotype B!, selected here; photo. at K). Additional original syntype: Namibia, Etiro, Feb. 1900, Dinter 1443 (B?+).

Spiny suffrutex or compact shrublet, $5-50 \mathrm{~cm}$ tall, branches erect or ascending from a woody base; stems markedly 4-angular, internodes glabrous or minutely puberulent on two opposite sides between the ridges, nodal line strigose. Axillary spines present or rarely absent, (greenish-) white, 2 - 4-rayed, stalk $0-1.5 \mathrm{~mm}$ long, longest ray $2-14 \mathrm{~mm}$ long. Leaves often held \pm erect at least towards apex of stems, sessile or petiole to $7 \mathrm{~mm}$ long; blade bright green, somewhat coriaceous, narrowly oblong-elliptic or oblanceolate, 1.8 $8.5 \times 0.6-2.3 \mathrm{~cm}$ (1:w ratio: $(2.2-) 2.6-4.8: 1$ ), base cuneate or attenuate, margin entire, apex acute to rounded, mucronate, surfaces glabrous or sparsely strigulose on margin and midrib beneath; lateral veins 3 - 6 pairs. Inflorescences axillary but sometimes clustered towards stem apices to form loose leafy spikes; flowers solitary at each axil, subsessile; bracts foliaceous but reduced distally, uppermost pairs typically $13-19 \times 3-5 \mathrm{~mm}$; bracteoles green with paler margin and midrib or more rarely whitish-green, lanceolate or oblong-lanceolate, 8 - $16(-21) \times 1.3-$ $3(-4) \mathrm{mm}$, margin entire, apex spinose, glabrous. Calyx green or whitish-green, anterior lobe lanceolate, $10-16 \times 3.5-6 \mathrm{~mm}$, posterior lobe somewhat longer, 12 - $19 \mathrm{~mm}$ long; both with apices \pm attenuate and spinose, anterior lobe often bifidly so, margin entire, venation parallel, prominent in fruit but often only 2 (anterior) or 1 (posterior) main vein prominent in flower, external surfaces glabrous or rarely with few minute hairs on veins and margin towards apex; lateral lobes linear-lanceolate, 9 - $16.5 \mathrm{~mm}$ long, usually with sparse hairs towards apex. Corolla (pale) yellow to pale orange or apricot-coloured, $26-41 \mathrm{~mm}$ long, shortly pubescent externally; tube cylindrical, 10.5 - $15 \times 2.5 \mathrm{~mm}$; limb in " $4+1$ " configuration; abaxial lobe offset by $6.5-9.5 \mathrm{~mm}$, narrowly oblong or oblong-obovate, $8-13.5 \times 3-6 \mathrm{~mm}$, apex rounded, usually with a minute acumen; lateral lobes obovate, $11-20 \times 7-11 \mathrm{~mm}$, apices acute, attenuate or rounded with a short acumen; adaxial lobes as lateral lobes but narrower, $5.5-10 \mathrm{~mm}$ wide. Stamens inserted $6.5-$ $8.5 \mathrm{~mm}$ from base of corolla tube; filaments $14-16 \mathrm{~mm}$ long, pubescent; anthers $2.2-3.5 \mathrm{~mm}$ long; lateral 

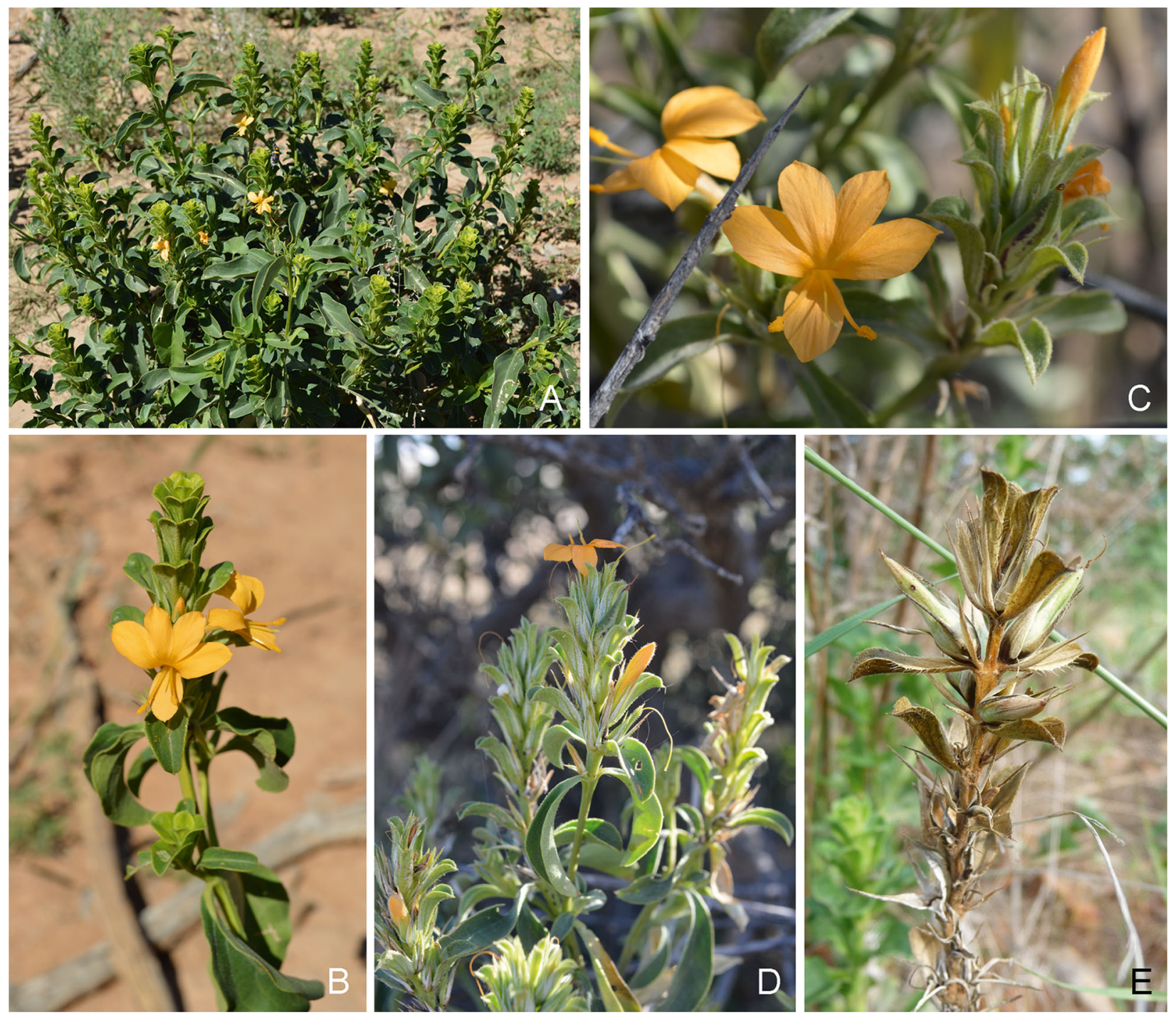

Fig. 16. Barleria senensis. A habit; B - D inflorescences; E fruiting. C \& D Klaassen et al. 2527 (Namibia); E Tripp 838 (Namibia). PHOTOS: A - D I. DARBYSHIRE (NAMIBIA); E E. A. TRIPP.

staminodes 1 - $1.5 \mathrm{~mm}$ long, pilose, antherodes $0.7-$ $1 \mathrm{~mm}$ long. Pistil glabrous; stigma linear, $1-1.5 \mathrm{~mm}$ long. Capsule $16-18 \mathrm{~mm}$ long, glabrous; seeds $8-10 \times 6-7.5$ mm. Fig. 17D - G.

DISTRIBUTION. Endemic to northern and central Namibia (Erongo, Kavango East, Khomas, Kunene, Omusati, Oshikoto \& Otjozondjupa regions). Map 11. SELECTED SPECIMENS EXAMINED. (Total of 48 collections seen). NAMIBIA. Damaraland, fl. 1879, Een s.n. (BM!); Otavi, fl. \& fr. 26 Jan. 1925, Dinter 5288 (BM!, BOL!); Outjo region, Farm Trocadero, fl. Jan. 1948, Karen Regius 67B (WIND!); about 3 miles N of Kamanjab on road to Ohopoho, fl. \& fr. 23 March 1957, de Winter Eं Leistner 5141 (K!, M!, PRE, WIND!); Grootfontein, Farm Lushof, fl. \& fr. 21 Nov. 1957, Giess 2114 (M!, WIND!); Etosha Game Park, 5 miles E of Okaukuejo, fl. 9 Jan. 1966, Tinley
1172 (WIND!); Farm Okomitundu, am Aufstieg zur Kuddufläche, fl. 18 Dec. 1967, Seydel 5571 (K!, M!, PRE, WAG*, WIND!); Farm Kumkauas: GR 552, fr. 12 March 1973, Giess 12588 (M!, WIND!); Otjiwarongo, fl. 15 March 1977, P. EO D. Craven 420 (WIND!); Etosha N.P., Otjovasandu, fl. March 1981, Horn s.n. (WIND!); Grootfontein Distr., Farm Henta 1036, fr. 7 April 1990, Strohbach 949 (WIND!); Grootfontein Distr., about 80 km from Rundu, Taranaki Farm, fl. 5 March 1995, Burgoyne 3246 (PRE!); Farm Uitkomst camp 46, fl. 8 March 1995, Sheuyange E Strohbach 88 (WIND!); Sonop R.S., on Moedhou north, next to Soverby border, fl. 1 April 1997, Strohbach E Sheuyange 2674 (WIND!); Farm Paresis 163, fl. \& fr. 26 Jan. 1998, Noczil-Ostermeier NOC 19 (WIND!); Grootfontein Distr., Sonop Observatory Plot 131, fl. \& fr. 26 April 2001, B. E् M. Strohbach 5215 (WIND!); Kaokoveld, fl. \& fr. 4 March 2003, Schubert SS23 (WIND!); Grootfontein 

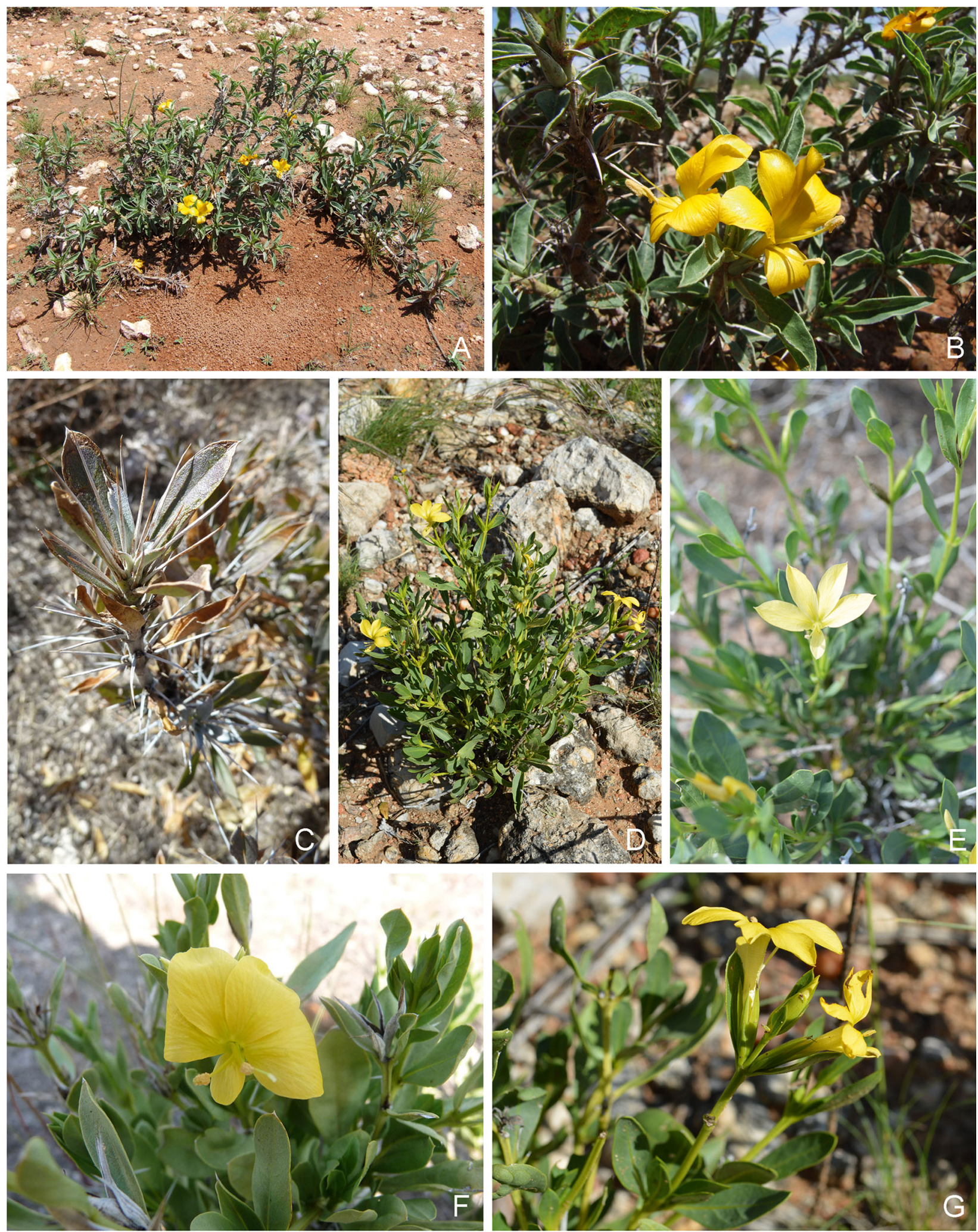

Fig. 17. A - C Barleria coriacea subsp. dinteri. A habit; B flowering branch; C foliage showing fine white indumentum. D - G B. kaloxytona. D habit; E \& F flowers, showing variation in corolla shape; G inflorescence. C Tripp \& Dexter 2032 (Namibia); D, E \& G Nyatoro et al. 25 (Namibia); F Tripp \& Dexter 818 (Namibia). PHotos: A \& B H. Kolberg (nAmiBIA); C, F E. A. TRIPP; D, E \& G I. DARBYSHIRE. 
Distr, along road D2860 towards Hoba meteorite, fl. 26 Jan. 2006, Bartsch et al. 2157 (WIND!); just W of D3022 and C42 junction, between Tsumeb and Grootfontein, fr. 20 March 2010, Tripp E Dexter 798 (K!, RSA!, WIND!); c. $20 \mathrm{~km} \mathrm{~W}$ of C38, NW of Outjo, fr. 22 March 2010, Tripp 818 (K!, RSA!, WIND!); 30 km $\mathrm{N}$ of Kamanjab on C35 towards Ruacana, fl. 13 Jan. 2013, Tripp et al. 4052 (COLO!, K!); Otjiwarongo, c. $30 \mathrm{~km}$ from Outjo town, opposite layby post on the way to Otjiwarongo on road C38, fl. 13 April 2015, Nyatoro et al. 25 (COLO!, K!, WIND!).

HABITAT \& ECOLOGY. Barleria kaloxytona has been recorded from a wide variety of dry open habitats including open Acacia and Acacia-CatophractesDichrostachys bushland, thicket and dwarf shrubland on sandy soils, grassland and open scrub on calcareous soils, and damp roadside depressions on clay; at 1100 $1500 \mathrm{~m}$ elevation. It occurs primarily in the Western Highlands, Western Kalahari and Karstveld vegetation types, just extending into the North-eastern Kalahari Woodlands vegetation type of Mendelsohn et al. (2002).

CONSERVATION STATUS. This species is widespread and locally frequent in northern Namibia, with an EOO of $182,557 \mathrm{~km}^{2}$. It is recorded from numerous localities, and appears to be frequent in Etosha National Park. Although some populations may suffer from overgrazing/browsing due to overstocking of domestic livestock and wild herbivores, it is not considered to be globally threatened and is assessed as of Least Concern - LC.

NOTES. This species replaces Barleria coriacea in northern Namibia, from which it is easily separated by the largely glabrous vegetative parts even when young, the greener bracteoles and calyces, the hairy corolla limb and the abaxial corolla lobe being clearly smaller than, not subequal to, the remaining lobes. The leaves are a rather vivid green which also helps to separate it from other species in sect. Prionitis.

32. Barleria fernandae I. Darbysh. sp. nov. Type: Angola, Huíla, Humbe, Huia, fl. 9 Dec. 1969, Sousa $\mathcal{E}$ Mendonça 38 (holotype LUBA! [LUBA026529-0]).

http://www.ipni.org/urn:lsid:ipni.org:names:60477660-2

Suffrutex with erect or ascending stems $20-50 \mathrm{~cm}$ tall from a woody base and rhizome; stems markedly 4 angular, puberulent mainly on two opposite grooves between the ridges, sparsely so elsewhere, nodal line strigose. Axillary spines absent. Leaves ascending, petiole to $6 \mathrm{~mm}$ long; blade narrowly oblong-lanceolate, 4.7 $5.5 \times 0.9-1.1 \mathrm{~cm}$ (1:w ratio: $4.9-5.2: 1$ ), base cuneate or attenuate, apex acute or somewhat obtuse, mucronate, margin and midrib beneath sparsely strigulose, else- where glabrous; lateral veins $4-5$ pairs, these and reticulate tertiary veins prominent on both surfaces. Inflorescences axillary, flowers solitary at each axil, subsessile; bracts foliaceous; bracteoles green, oblonglanceolate or -linear, $13.5-21 \times 2-3 \mathrm{~mm}$, apex spinulose, midrib prominent beneath, this and margin sparsely strigulose. Calyx green, anterior lobe broadly lanceolate, $14-18.5 \times 6-6.5 \mathrm{~mm}$, base rounded, margin involute, apex attenuate, often notched for up to $2 \mathrm{~mm}$, with spinulose tip(s), external surface glabrous, internal surface finely strigulose, venation subparallel, rather prominent externally particularly the central pair of veins; posterior lobe as anterior lobe but $18-21.5 \times 6.5-$ $9 \mathrm{~mm}$; apex more markedly attenuate into spine-tip, midrib most prominent, this sometimes with few strigose hairs; lateral lobes linear-lanceolate, 13.5 - 17 mm long, with short hairs towards apex. Corolla yellow, $33-35 \mathrm{~mm}$ long, shortly pubescent externally particularly on tube distally; tube cylindrical, $16-16.5 \mathrm{~mm}$ long; limb subregular; abaxial lobe offset by $1.5-2.5 \mathrm{~mm}$, obovate, $14.5-15.5 \times 9.5-10.5 \mathrm{~mm}$, apex rounded; lateral lobes obovate to broadly so, $15-17 \times 10.5-12.5 \mathrm{~mm}$, apices rounded or emarginate; adaxial lobes as lateral lobes but narrower, 9 - $10.5 \mathrm{~mm}$ wide. Stamens inserted c. $9 \mathrm{~mm}$ from base of corolla tube; filaments $13-14 \mathrm{~mm}$ long, pubescent for most of length; anthers $3-3.5 \mathrm{~mm}$ long; lateral staminodes $\pm 0.7 \mathrm{~mm}$ long, pubescent, antherodes $0.9-1 \mathrm{~mm}$ long. Pistil glabrous; stigma linear, 1.3 - $1.8 \mathrm{~mm}$ long. Capsule not seen. Fig. 18.

RECOGNITION. Barleria fernandae is morphologically close to B. kaloxytona but differs in having a subregular corolla limb, the abaxial lobe being only barely offset from the other lobes and similar in size, $14.5-15.5 \times 9.5-10.5 \mathrm{~mm}$ (vs corolla in " $4+1$ " configuration, the abaxial lobe being offset by $6.5-$ $9.5 \mathrm{~mm}$ and markedly smaller than the other lobes, 8 - $13.5 \times 3-6 \mathrm{~mm}$ ), by the corolla lobes being rounded or slightly emarginate at the apices (vs usually with acute, attenuate or shortly acuminate apices) and by having larger and proportionately broader outer calyx lobes with involute margins, the posterior lobe $18-21.5 \times 6.5-9 \mathrm{~mm}$ in flower (vs lobes without involute margins, posterior lobe 12 $19 \times 3.5-6 \mathrm{~mm})$.

DISTRIBUTION. Endemic to southern Angola (Cunene Prov.). Map 9.

SPECIMEN EXAMINED. ANGOLA. Huíla, Humbe, Huia [Uia] na picada para a ?Chimpica Viwe [indecipherable], fl. 9 Dec. 1969, Sousa Eे Mendonça 38 (LUBA! holotype).

HABITAT \& ECOLOGY. No habitat information was recorded on the type specimen, however the region from where it derived is generally characterised by a semi-arid climate dominated by Colophospermum mopane to mixed mopane-miombo woodland; the type locality is estimated to be at $\pm 1100 \mathrm{~m}$ elevation. 


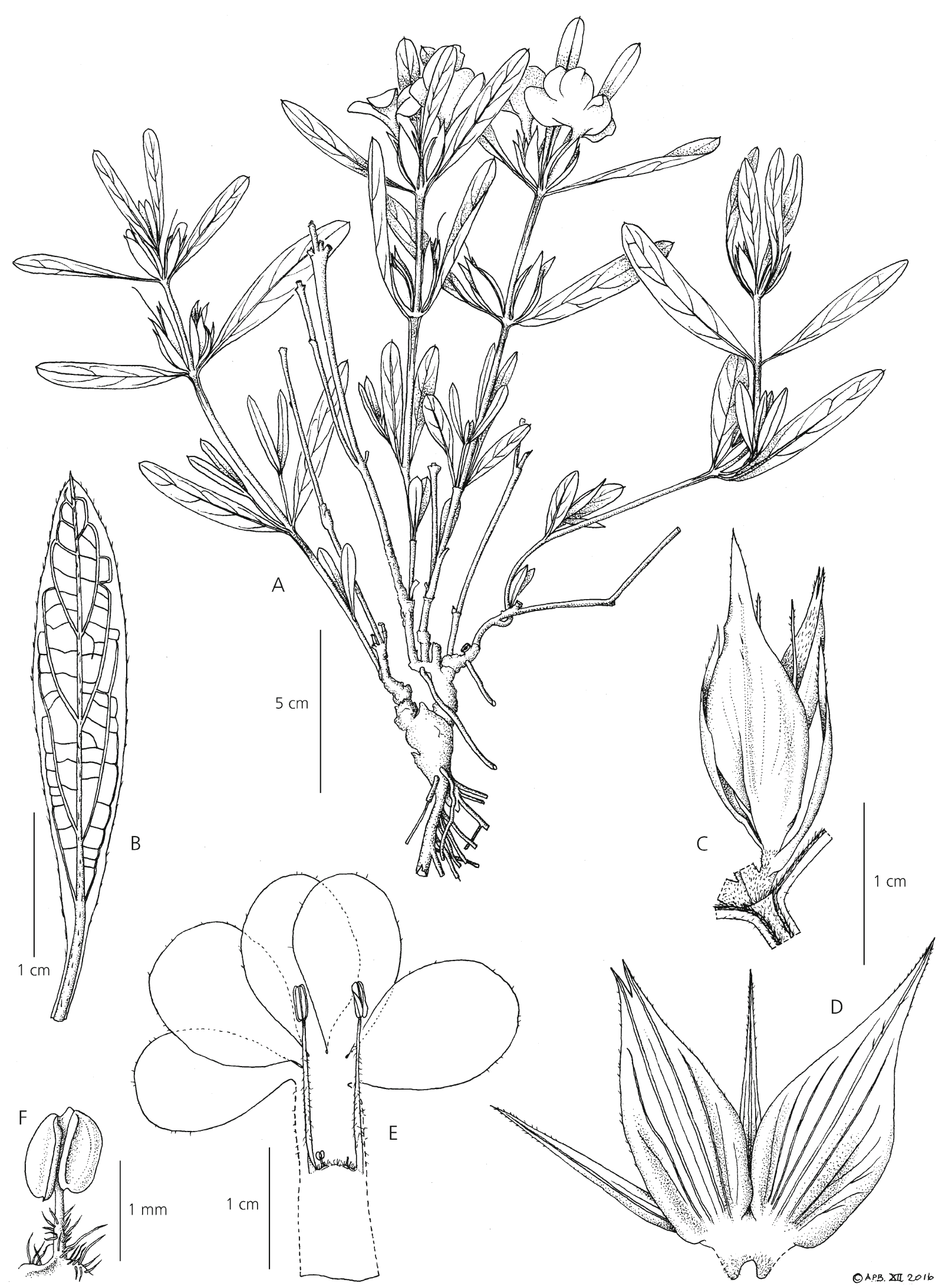

Fig. 18. Barleria fernandae. A habit; B leaf, abaxial surface; C calyx and bracteoles in situ, posterior view; D dissected calyx, external surface, posterior lobe ot the right; E dissected corolla with androecium; F detail of lateral staminode. From Sousa \& Mendonça 38. DRAWN BY ANDREW BROWN. 
CONSERVATION STATUS. Barleria fernandae is known only from the type locality, which has not been precisely geolocated but is close to Uia, between Cahama and Xangongo on the main route between Lubango and the Namibian border, following the Caculuvar River valley. The species was recorded as very abundant at this locality but it is clearly highly localised as it has not been collected by other botanists working in this region, such as $\mathrm{H}$. H. W. Pearson. There are numerous settlements and agricultural lands along the main road here, but away from this major transport route, this region is sparsely populated and Google Earth imagery shows extensive areas of apparently intact habitat to the north and south of the road. As we currently have no information on the precise habitat for this species, it must be assessed as Data Deficient - DD but it may prove to be unthreatened despite its range restriction.

ETYMOLOGY. This species is named in honour of Prof. Fernanda Lages, Head of the Collections at the Instituto Superior de Ciências de Educação, Huíla which includes the LUBA herbarium. Prof. Lages has been very helpful in providing access to the Barleria specimens from this important herbarium and was also a very accommodating host when the second author of this paper visited LUBA together with $\mathrm{K}$. Dexter to study the Petalidium collections in April 2017. It was thanks to Prof. Lages arranging for scanned images of all the unidentified Acanthaceae at LUBA to be sent to the first author that this new species was discovered.

NOTES. This species is clearly closely allied to Barleria kaloxytona and B. coriacea, sharing a similar habit, foliage and inflorescence form. It is particularly similar to B. kaloxytona with which it also shares the largely glabrous vegetative parts and pubescent corolla. However, it differs in the subregular corolla and the larger, proportionately broader calyx outer lobes. This is one of several cases in sect. Prionitis in which there appear to be species pairs that differ primarily in the corolla form subactinomorphic vs highly zygomorphic. Other examples include B. compacta Malombe \& I. Darbysh. and $B$. brevispina (Fiori) Hedrén in the Horn of Africa, $B$. subregularis I. Darbysh. and B. ameliae from central and southern Africa, and B. marginata Oliv. and B. linearifolia Rendle from eastern Africa (Darbyshire 2010b; Malombe \& Darbyshire 2010).

\section{Acknowledgements}

The Namibian component of this research, including fieldwork and research visits to WIND herbarium, was primarily supported by the Southern African Science Service Centre for Climate Change and Adaptive Land Management (SASSCAL) programme, Task 060 - "Establish and Improve baseline inventories for spatial data and biodiversity - Flora of Namibia Project". We particularly thank Mrs Esmerialda Strauss, Head of the National Botanical Research Institute (NBRI) of Namibia, for inviting and overseeing our participation in this programme and for kindly facilitating the research visits of I. Darbyshire and E. Tripp to Namibia between 2010 and 2015. Ezekeil Kwembeya of the University of Namibia (formerly of NBRI) is also thanked for his input and early facilitation of this research. Fieldwork in Namibia by E. Tripp and colleagues was supported by a U.S. National Science Foundation grant DEB-0919594 to E. Tripp \& L. McDade. Additional fieldwork in Namibia as well as fieldwork in Angola was supported by NSF grants DEB-1354963 and DEB-1355138 to E. Tripp and L. McDade, and funding from the Systematics Association, the British Ecological Society, and the Moray Endowment Fund of the University of Edinburgh. We thank the Ministry of Environment and Tourism in Namibia for granting our research permits in that country, and the Ministry of Agriculture of Angola for granting research permits in that country. Fernanda Lages and Francisco Gonçalves of the Instituto Superior de Ciências de Educação, Huíla, are warmly thanked for their assistance in providing access to collections from the LUBA herbarium and for logisitical support for Angolan fieldwork by E. Tripp and K. Dexter. I. Darbyshire thanks de Beers Angola Prospecting Ltd. for providing logistic support during his 2013 visit to Angola, which included a visit to the LUAI herbarium. We are grateful to all our fieldwork collaborators. In particular, Kyle Dexter (University of Edinburgh) has been a key collaborator on many of the fieldtrips through Namibia and Angola and is thanked for his extensive contributions. Leevi Nanyeni of NBRI is thanked for his excellent contribution to the Namibian fieldwork; Leevi was also a great help with addressing various queries regarding specimens in the WIND herbarium. We would also like to thank the following curators and research staff for providing access to the herbarium collections of Barleria at their institutions: Robert Vogt (B), Ranee Prakash and Jacek Wajer (BM), Thea Lautenschläger (DR), Maria Romeiras and Maria Cristina Duarte (LISC), Ana Isabel Correia (LISU), Esperança da Costa (LUAI), Andreas Fleischmann and Hans-Joachim Esser (M), Alpheus Mothapo and Hester Steyn (PRE), Christopher Chapano and Anthony Mapaura (SRGH) and Hendrina Hasheela, David Aiyambo and Leevi Nanyeni (WIND). We thank David Goyder of the Royal Botanic Gardens, Kew for seeking out Acanthaceae during his various expeditions to Angola over the past few years and for his helpful advice on the phytogeography of that fascinating country. Patricia Craven has helpfully provided information on species distributions and collections of Barleria in Namibia. Equally, Willem Froneman of the South African National Biodiversity Institute (SANBI) has provided useful information on and photographs of the southern African species of Barleria, and it has been 
very rewarding to communicate with another Barleria enthusiast! We are highly grateful to Andrew Brown for the excellent illustrations of the newly described species, and to Martin Cheek, Willem Froneman, David Goyder, Herta Kolberg, Coleen Mannheimer and Bart Wursten for kindly allowing us to reproduce their photographs of Barleria species in the field.

Open Access This article is distributed under the terms of the Creative Commons Attribution 4.0 International License (http://creativecommons.org/ licenses/by/4.0/), which permits unrestricted use, distribution, and reproduction in any medium, provided you give appropriate credit to the original author(s) and the source, provide a link to the Creative Commons license, and indicate if changes were made.

\section{References}

Albuquerque, S. \& Correia, A. I. (2009). The Welwitsch collections; Iter Angolense (1853 - 1860) at LISU. In: X. van der Burgt, J. van der Maesen \& J.-M. Onana (eds), Systematics and Conservation of African Plants. Proceedings of the $18^{\text {th }}$ AETFAT Congress, Yaoundé, Cameroon, pp. 787 - 790. Royal Botanic Gardens, Kew.

Anderson, T. (1863). An enumeration of the species of Acanthaceae from the continent of Africa and the adjacent islands. J. Proc. Linn. Soc., Bot. 7: 13 - 54 .

Bachman, S., Moat, J., Hill, A. W., de la Torre, J. \& Scott, B. (2011). Supporting red list threat assessments with GeoCAT: Geospatial conservation assessment tool. ZooKeys 150: 117 - 126.

Baillon, M. H. (1890). Sur quelques types anomaux d'Acanthacées. Bull. Mens. Soc. Linn. Paris 2: 835 - 838.

Balarin, M. G., Brink, E. \& Glen, H. F. (1999). Itinerary and specimen list of M. A. Pocock's botanical collecting expedition in Zambia and Angola in 1925. Bothalia 29: $169-201$.

Balkwill, M. J. (1993). A reappraisal of the generic limits and subdivision of Barleria L. (Acanthaceae). Unpubl. Ph.D. thesis, University of the Witwatersrand, Johannesburg.

\& Balkwill, K. (1997). Delimitation and infrageneric classification of Barleria (Acanthaceae). Kew Bull. 52: 535 - 573.

\& ____ (1998). A preliminary analysis of distribution patterns in a large, pantropical genus, Barleria L. (Acanthaceae). J. Biogeogr. 25: 95 - 110. \& Vincent, P. L. D. (1990). Systematic studies in the Acanthaceae: a new species of Barleria from Natal. S. African J. Bot. 56: $571-576$.

, Stalmans, M. \& Balkwill, K. (1992). Systematic studies in the Acanthaceae: a new species of Barleria from the north-eastern Transvaal, with some notes on its ecology. S. African J. Bot. 58: $286-291$.
Beentje, H. (2016). Tropical African floras: progress, gaps, and future. Symb. Bot. Upsal. 38: 101 - 119.

Benoist, R. (1950). Quelques Acanthacées des colonies Portugaises Africanes. Bol. Soc. Brot. Sér. 2, 24: 5 - 39. (1967). Acanthacées. Tome I. In: H. Humbert (ed.), Flore de Madagascar et des Comores. Museum National d'Histoire Naturelle, Laboratoire de Phanérogamie, Paris.

BirdLife International (2017). Important Bird Areas factsheet: Waterberg Plateau Park. Downloaded from http://www.birdlife.org. on 12 Sept. 2017.

Brown, N. E. (1909). List of plants collected in Ngamiland and the northern part of the Kalahari Desert. Bull. Misc. Inform., Kew: 89 - 146.

Bruyns, P. V. (2015). The Apocynaceae of Namibia. Strelitzia 34. South African National Biodiversity Institute, Pretoria.

Burke, A. (2005). Wild flowers of the northern Namib. Namibia Scientific Society, Windhoek.

Cavaco, A. (1959). Subsídios para o estudo da biologia na Lunda. Contribution à l'étude de la flore de la Lunda d'après les récoltés de Gossweiler (1946 - 1948). Museo do Dundo. Publicações Culturais da Companhia de Diamantes de Angola (DIAMANG) No. 42.

Champluvier, D. (2011). New and overlooked Acanthaceae taxa from D. R. Congo, Rwanda and Burundi: (1) the genus Barleria. Pl. Ecol. Evol. 144: 82 - 95.

\& Darbyshire, I. (2012). Schaueriopsis: a new genus of Acanthaceae (Acanthoideae: Barlerieae) from the Democratic Republic of Congo. Pl. Ecol. Evol. 145: 279 - 284.

Cheek, M., Poveda, L. L. \& Darbyshire, I. (2015). Ledermaniella lunda sp. nov. (Podostemaceae) of Lunda Norte, Angola. Kew Bull. 70: 10 (5 pages).

Clarke, C. B. (1884). Barleria. In: J. D. Hooker (ed.), Flora of British India 4: 482 - 490. L. Reeve \& Co., London.

(1899). Barleria. In: I. H. Burkill \& C. B. Clarke (1899 - 1900), Acanthaceae. In: W. T. ThiseltonDyer (ed.), Flora of Tropical Africa 5: 140 - 169. L. Reeve \& Co., London.

(1901). Barleria. In: W. T. Thiselton-Dyer (ed.), Flora Capensis. Vol. 5 (Pt. 1): 44 - 55 . L. Reeve \& Co., London.

Compton, R. H. (1976). The Flora of Swaziland. J. South African Bot., Suppl. Vol. 11.

Craven, P. (ed.) (1999). A checklist of Namibian plant species. South African Botanical Diversity Network Report No. 7, SABONET, Windhoek. (2009). Phytogeographic study of the Kaokoveld Centre of Endemism. Ph.D. thesis, University of Stellenbosch. http:/ / hdl.handle.net/10019.1/1325

(2014). Unpublished Report. http://herbaria. plants.ox.ac.uk/bol/petalidium

Darbyshire, I. (2008). New species in Barleria sect. Stellatohirta (Acanthaceae) from Africa. Kew Bull. 63: 261 - 268. (2009). A reassessment of the status of Barleria sect. Cavirostrata (Acanthaceae) in tropical Africa, 
with a new species, B. richardsiae, described from the Tanzania-Zambia border region. Kew Bull. 63: $601-611$.

(2010a). The Barleria fulvostellata (Acanthaceae) complex in east Africa. Kew Bull. 64: 673 - 679.

(2010b). Barleria. In: H. J. Beentje (ed.), Flora of Tropical East Africa. Acanthaceae, pp. 325 - 442. Royal Botanic Gardens, Kew.

(2011). Barleria superata (Acanthaceae): a new suffruticose herb endemic to Burundi. Pl. Ecol. Evol. 144: $367-371$.

(2015). Barleria. In: J. R. Timberlake \& E. S. Martins (eds), Flora Zambesiaca. Vol. 8 (6): 37 - 122. Royal Botanic Gardens, Kew.

, Fisher, A. E., Kiel, C. A. \& McDade, L. A. (in press). Phylogenetic relationships among species of Barleria (Acanthaceae, Lamiales): molecular data reveal complex patterns of morphological evolution and support a revised classification. Taxon.

, Kordofani, M., Farag, I., Candiga, R. \& Pickering, H. (eds) (2015a). The Plants of Sudan and South Sudan. An annotated checklist. Royal Botanic Gardens, Kew.

\& Luke, Q. (2016). Barleria mirabilis (Acanthaceae): a remarkable new tree species from west Tanzania. Kew Bull. 17: 13 (6 pages).

McCleland, W. \& Froneman, W. (2017). Barleria lebomboensis (Acanthaceae), an endangered new species from the Lebombo Mountains of Swaziland. Phytotaxa 323: 173 - 181.

, Nanyeni, L., Chase, F. M. \& Gonçalves, F. M. P. (2018). A synopsis of Rhinacanthus (Acanthaceae) in Angola and Namibia. Kew Bull. 73: 21. 10.1007/ s12225-018-9746-5

\& Ndangalasi, H. J. (2009). Three new species of Barleria sect. Somalia (Acanthaceae) from the miombo woodlands of western Tanzania. J. E. Africa Nat. Hist. Soc. Natl. Mus. 97: 123 - 134.

, Phillipson, P. B. \& Rakotonasolo, F. (2014). Additions to the genus Barleria in Madagascar. Kew Bull. 69: 9513 (11 pages).

Tripp, E. A. \& Dexter, K. G. (2012). A new species and a revised record in Namibian Barleria (Acanthaceae). Kew Bull. 67: 759 - 766.

, Vollesen, K. \& Ensermu Kelbessa (2010). Acanthaceae (Part 2). In: H. J. Beentje (ed.), Flora of Tropical East Africa. Royal Botanic Gardens, Kew. \& __ (2015b). Acanthaceae (Part 2). In: J. R. Timberlake \& E. S. Martins (eds), Flora Zambesiaca. Vol. 8 (6). Royal Botanic Gardens, Kew.

Dinter, K. (1918). Index der aus DeutschSüdwestafrika bis zum jahre 1917 bekannt gewordenen pflanzenarten. II. Repert. Spec. Nov. Regni Veg. 15: 340 - 355.

Engler, A. (1888). Plantae Marlothianae. Ein Beitrag zur Kenntnis der Flora Südafrikas. Bot. Jahrb. Syst. 10: $242-285$.
Ensermu Kelbessa (2006). Acanthaceae. In: I. Hedberg, Ensermu Kelbessa, S. Edwards, Sebsebe Demissew \& E. Persson (eds), Flora of Ethiopia E E Eritrea Vol. 5: 345 - 495. The National Herbarium, Addis Ababa University \& The Department of Systematic Botany, Uppsala University.

\& Darbyshire, I. (2017). Six new species of Barleria L. (Acanthaceae) from Northeast Tropical Africa. Kew Bull. 73: 1 (23 pages).

Exell, A. W. \& Gonçalves, M. L. (1973). A statistical analysis of a sample of the flora of Angola. Garcia de Orta, Sér. Bot. 1: $105-128$.

Fenzl, E. (1844). Aufzählung mehrerer neuen aethiopischen pflanzen-gattungen und arten, nebst Anzeige einer erscheinenden synopsis florae aethiopicae. Flora 27: 309 - 312.

Figueiredo, E. (2008). The Rubiaceae of Angola. Bot. J. Linn. Soc. 156: 537 - 638.

\& Smith, G. F. (2008). Plants of Angola / Plantas de Angola. Strelitzia 22. South African National Biodiversity Institute, Pretoria.

Soares, M., Seibert, G., Smith, G. F. \& Faden, R. B. (2009). The botany of the Cunene-Zambezi Expedition with notes on Hugo Baum (1967 1950). Bothalia 39: $185-211$.

Giess, W. (1971). A preliminary vegetation map of South West Africa. Dinteria 4: 1 - 114.

Gunn, M. \& Codd, L. E. (1981). Botanical exploration of southern Africa: an illustrated history of early botanical literature on the Cape flora: biographical accounts of the leading plant collectors and their activities in southern Africa from the days of the East India Company until modern times. A. A. Balkema, Cape Town.

Hedrén, M. (2006a). New species and combinations in Acanthaceae from Somalia. Willdenowia 36: 751 - 759 .

(2006b). Barleria. In: M. Thulin (ed.), Flora of Somalia. Vol. 3: 427 - 442. Royal Botanic Gardens, Kew.

\& Thulin, M. (2006). Acanthaceae. In: M. Thulin (ed.), Flora of Somalia. Vol. 3: 374 - 454. Royal Botanic Gardens, Kew.

Heine, H. (1963). Acanthaceae. In: F. N. Hepper (ed.), Flora of West Tropical Africa. Second Edition, Vol. 2: 391 - 432. Crown Agents for Overseas Governments and Administrations, London.

(1966). Acanthacées. In: A. Aubreville (ed.), Flore du Gabon Vol. 13: 3 - 250. Museum National d'Histoire Naturelle, Paris.

Hiern, W. P. H. (1900). Catalogue of the African plants collected by Friedrich Welwitsch in 1853 - 1861. Dicotyledons, part IV Lentibulariaceae to Ceratophylleae. British Museum (Natural History), London.

Hilliard, O. M. (1994). The Manuleae: a tribe of Scrophulariaceae. Edinburgh University Press, Edinburgh. 
Humbert, H. (1937). Isaloa, genre nouveau de Scrophulariacées de Madagascar. Bull. Soc. Bot. France 84: 313 - 317.

Huntley, B. (2011). Biodiversity Rapid Assessment of the Lagoa Carumbo area, Lunda Norte, Angola. Unpubl. Report.

IUCN (2012). IUCN Red List Categories and Criteria. Version 3.1. Second Edition. IUCN Species Survival Commission, Gland \& Cambridge.

Klaassen, E. \& Kwembeya, E. (eds) (2013). A checklist of Namibian indigenous and naturalised plants. Occasional Contributions No. 5, National Botanical Research Institute, Windhoek.

Klopper, R. R., Chatelain, C., Bänninger, V., Habashi, C., Steyn, H. M., de Wet, B. C., Arnold, T. H., Gautier, L., Smith, G. E. \& Spichiger, R. (2006). Checklist of the flowering plants of sub-Saharan Africa. An index of accepted names and synonyms. South African Botanical Diversity Network Report No. 42, SABONET, Pretoria.

Klotzsch, J. F. (1861). Acanthaceae. In: W. C. H. Peters, Naturwissenschaftliche Reise nach Mossambique. VI: Botanik, pp. 140 - 169. G. Reimer, Berlin.

Knees, S. G., Laser, S., Miller, A. G. \& Patzelt, A. (2007). A new species of Barleria (Acanthaceae) from Oman. Edinburgh J. Bot. 64: 107 - 112.

Lebrun, J.-P. \& Stork, A. L. (2006). Tropical African Flowering Plants. Ecology and Distribution. Vol. 2 Euphorbiaceae - Dichapetalaceae. Conservatoire et Jardin botaniques de la Ville de Genève, Geneva.

Leistner, O. A. \& Morris, J. W. (1976). Southern African Place Names. Ann. Cape Prov. Mus. Nat. Hist. Vol. 12. Albany Museum, Grahamstown.

Lindau, G. (1909). Acanthaceae africanae. VIII. Bot. Jahrb. Syst. 43: 349 - 358.

(1911).Acanthaceae.In:J.Mildbraed, Wissenschaftiche Ergebnisse der Deutschen Zentral-Afrika Expedition 1907 1908, Band II. Botanik, pp. 291 - 310. Klinkhardt \& Biermann, Leipzig.

(1920). Acanthaceae africanae. X. Bot. Jahrb. Syst. 57: $20-24$.

Linder, H. P. (2001). Plant diversity and endemism in sub-Saharan tropical Africa. J. Biogeogr. 28: 169 - 182.

Linnaeus, C. (1753). Species Plantarum. Vol. 2. Salvius, Stockholm.

Loots, S. (2005). Red data book of Namibian plants. Southern African Botanical Diversity Network Report Series No. 38. SABONET, Pretoria.

Luke, Q., Bangirinama, F., Beentje, H. J., Darbyshire, I., Gereau, R., Kabuye, C., Kalema, J., Kelbessa, E., Kindeketa, W., Minani, V., Mwangoka, M. \& Ndangalasi, H. (2015). Barleria pseudosomalia. The IUCN Red List of Threatened Species. Version 2015.2. www.iucnredlist.orgDownloaded on $16 \mathrm{Ju}-$ ly 2015 .

Makholela, T. (2008). Acanthaceae. In: E. Figueiredo \& G. F. Smith (eds), Plants of Angola / Plantas de
Angola. Strelitzia 22. South African National Biodiversity Institute, Pretoria.

Malombe, I. \& Darbyshire, I. (2010). Barleria compacta: a new species in Barleria sect. Prionitis (Acanthaceae) from Somalia. Kew Bull. 65: 443 - 447.

Mannheimer, C. (2012). Wildflowers of the Central Highlands of Namibia. MacMillan Namibia, Windhoek.

Mapaura, A., Timberlake, J. \& Kamumvuri, G. (2004). Acanthaceae. In: A. Mapaura \& J. Timberlake (eds), A checklist of Zimbabwean vascular plants. Southern African Botanical Diversity Network Report No. 33: 13 - 15. SABONET, Pretoria.

Marloth, R. (1932). The Flora of South Africa. Vol. III Sympetalae; Sect. II Myoporaceae - Compositae. Darter Bros. \& Co., Cape Town; Whelden \& Wesley Ltd., London.

Masters, M. T. (1870). New Garden Plants. Barleria lichtensteiniana Nees v. Esenb. Gard. Chron. 1870: 73.

McDade, L. A., Daniel, T. F. \& Kiel, C. A. (2008). Toward a comprehensive understanding of phylogenetic relationships among lineages of Acanthaceae s.l. (Lamiales). Amer. J. Bot. 95: 1136 - 1152.

Meeuse, A. (1961). Barleria ameliae. In: Various Authors, Notes and new records of African plants. Bothalia 7: 443 - 444.

Mendelsohn, J., Jarvis, A., Roberts, C. \& Robertson, T. (2002). Atlas of Namibia. A portrait of the land and its people. Ministry of Environment \& Tourism and David Philip, Cape Town.

Meyer, P. G. (1957). Beitrag zur Kenntnis der Acanthaceen Südwestafrikas. Mitt. Bot. Staatssamml. München 2: 368 - 385.

(1961). Beiträge zur Kenntnis der Acanthaceen Südwestafrikas (III). Mitt. Bot. Staatssamml. München 4: $59-72$.

(1967). Beiträge zur Kenntnis der Acanthaceen Südwestafrikas. Mitt. Bot. Staatssamml. München 6: $505-515$.

(1968). 130. Acanthaceae. In H. Merxmüller (ed.), Prodromus einer Flora von Südwestafrika. J. Cramer, Germany.

Mildbraed, J. (1930). Acanthaceae novae. Notizbl. Bot. Gart. Berlin-Dahlem 11: 62 - 71.

Moore, S. le (1880). Enumeratio Acanthacearum Herbarii Welwitschiani Angolensis. J. Bot. 18: 193 199,225 - 233, 265 - 270, 307 - 314, 340 - 342 \& 362 366.

(1902a). Alabastra Diversa. Part IX. New Acanthaceae from tropical Africa. J. Bot. 40: 305-310. (1902b). Alabastra Diversa. Part X. Two imperfectly known species of Barleria. J. Bot. 40: 407 - 408. (1907). Alabastra Diversa. Part XV. 1. New or rare Acanthaceae from German South-West Africa. J. Bot. 45: 226 - 233.

(1908). Alabastra Diversa. Part XVI. New or rare African plants. J. Bot. 46: $71-76$. 
(1911). Alabastra Diversa. Part XXI. Acanthaceae Africanae Novae. J. Bot. 49: 293 - 298 \& 305 - 313. (1930). Mr John Gossweiler's plants from Angola and Portuguese Congo. Acanthaceae. J. Bot. 68, Suppl. II: 126 - 139.

Mosti, S., Raffaelli, M. \& Tardelli, M. (2011). Barleria almughsaylensis Mosti, Raffaelli \& Tardelli (Acanthaceae), a new species from Oman. Candollea 66: 191 - 197.

Nees von Esenbeck, C. G. D. (1847). Acanthaceae. In: A. de Candolle (ed.), Prodromus Systematis Naturalis Regni Vegetabilis. Vol. 11: 46 - 51. Masson, Paris.

Nyirenda, F. C. (2012). Morphological variation in five related species of Barleria (Acanthaceae). Unpubl. M.Sc. thesis, University of the Witwatersrand, Johannesburg.

\& Balkwill, K. (2018). Significance of variation and evaluation of potential characters in three morphologically similar species of Barleria sect. Barleria (Acanthaceae) in southern Africa. Pl. Syst. Evol. 304: 77 - 92.

Obermeyer, A. A. (1933). A revision of the South African species of Barleria. Ann. Transvaal Mus. 15: 123 - 180.

Oersted, A. S. (1854). Mexicos og Centralamerikas Acanthaceer. Vidensk. Meddel. Naturhist. Foren. Kjøbenhavn: 113 - 181.

Raimondo, D., Von Staden, L., Foden, W., Victor, J. E., Helme, N. A., Turner, R. C., Kamundi, D. A. \& Manyama, P. A. (eds) (2009). Red List of South African Plants. Strelitzia 25. South African National Biodiversity Institute, Pretoria.

Rendle, A. B., Baker, E. G., Wernham, H. F., Moore, S. et al. (1913). Catalogue of the Plants Collected by Mr. E Mrs, P. A. Talbot in the Oban District, South Nigeria. British Museum, Natural History, London.

Schinz, H. (1890). Beiträge zur Kenntnis der Flora von Deutsch-Südwest Afrika und der angrenzenden Gebiete. IV. Verh. Bot. Vereins Prov. Brandenburg 31: 177 - 230.

Scotland, R. W. \& Vollesen, K. (2000). Classification of Acanthaceae. Kew Bull. 55: 513 - 589.

Shendage, S. M. \& Yadav, S. R. (2010). Revision of the genus Barleria (Acanthaceae) in India. Rheedea 20: 81 - 130.

Singh, Y., Baijnath, H. \& Condy, G. (2015). Barleria elegans. Fl. Pl. Africa 64: pl. 2316, 136 - 142.

Smith, T. J. (ed.) (2005). Important Plant Areas in southern Africa. Combined proceedings of workshops held in Mozambique, Namibia and South Africa. Southern African Botanical Diversity Network Report Series No. 39. SABONET, Pretoria.

Sonder, W. (1850). Beiträge zur Flora von Südafrika. Linnaea 23: 1 - 138.

Sosef, M. S. M. (2006). Acanthaceae. In: M. S. M. Sosef et al. (eds), Check-list des plantes vasculaires du Gabon / Checklist of Gabonese vascular plants. Scripta Bot. Belg. Vol. 35. Jardin Botanique National du Belgique, Meise.

Struwig, M., Klaassen, E. \& Kwembeya, E. G. (2015). Nyctaginaceae: a taxonomic treatment for the Flora of Namibia. Phytotaxa 238: 101 - 135.
Teixeira, J. B. (1968). Angola. In: I. Hedberg \& O. Hedberg (eds), Conservation of Vegetation in Africa South of the Sahara. Proceedings of a symposium held at the $6^{\text {th }}$ Plenary meeting of the "Association pour l'Etude Taxonomique de la Flore d'Afrique Tropicale" (AETFAT) in Uppsala, Sept. $12^{\text {th }}-16^{\text {th }}$, 1966. Acta Phytogeogr. Suecica 54: 193 - 197. Almqvist \& WiksellsBoktryckeri AB, Uppsala.

Tripp, E. A. \& Darbyshire, I. (2017). Phylogenetic relationships among Old World Ruellia L.: a new classification and reinstatement of the genus Dinteracanthus Schinz. Syst. Bot. 42: 470 - 483.

Daniel, T. F., Fatimah, S. \& McDade, L. A. (2013). Phylogenetic relationships within Ruellieae (Acanthaceae) and a revised classification. Int. J. Pl. Sci. 174: 97 - 137.

\& Dexter, K. G. (2012). Taxonomic novelties in Namibian Ruellia (Acanthaceae). Syst. Bot. 37:1023-1030. , Tsai, Y.-H. E., Zhuang, Y. \& Dexter, K. (2017). RADseq dataset with $90 \%$ missing data fully resolves recent radiation of Petalidium (Acanthaceae) in the ultra-arid deserts of Namibia. Ecol. Evol. 7: 7920 7936. DOI: $10.1002 /$ ece3.3274.

Van Wyk, A. E. \& Smith, G. F. (2001). Regions of Floristic Endemism in Southern Africa. A review with emphasis on succulents. Umdaus Press, Hatfield.

Verdcourt, B. (1969). The arid corridor between the north-east and south-west areas of Africa. In: E. M. van Zinderen Bakker (ed.), Palaeoecology of Africa and of the surrounding islands and Antarctica. Vol. 4: 140 - 144. A. A. Balkema, Cape Town.

Vollesen, K. (2008). Acanthaceae (Part 1). In: H. J. Beentje \& S. A. Ghazanfar (eds), Flora of Tropical East Africa. Royal Botanic Gardens, Kew.

(2013).Acanthaceae (Part 1).In:J.R. Timberlake \&E. S. Martins (eds), Flora Zambesiaca. Vol. 8 (5). Royal Botanic Gardens, Kew.

Welman, W. G. (2003). Acanthaceae. In: G. Germishuizen \& N. L. Meyer (eds), Plants of southern Africa: an annotated checklist. Strelitzia 14: 92 - 106. National Botanical Institute, Pretoria.

White, F. (1983). Vegetation of Africa. A Descriptive Memoir to Accompany the UNESCO/AETFAT/UNSO Vegetation Map of Africa. UNESCO, Paris.

Winter, B. de (1971). Floristic relationship between the northern and southern arid areas in Africa. Mitt. Bot. Staatssamml. München 10: 424 - 437.

Wood, J. R. I., Hillcoat, D. \& Brummitt, R. K. (1983). Notes on the types of some names of Arabian Acanthaceae in the Forsskal herbarium. Kew Bull. 38: 429 - 456.

\section{Publisher's Note}

Springer Nature remains neutral with regard to jurisdictional claims in published maps and institutional affiliations. 